\title{
The Effects of the Ben Franklin Dam on the Hanford Site
}

Harold Harty, Project Manager

April 1979

Prepared for the U.S. Department of Energy under Contract EY-76-C-06-1830

Pacific Northwest Laboratory Operated for the U.S. Department of Energy by Battelle Memorial Institute 


\section{NOTICE}

This report was prepared as an account of work sponsored by the United States Government. Neither the United States nor the Department of Energy, nor any of their employees, nor any of their contractors, subcontractors, or their employees, makes any warranty, express or implied, or assumes any legal liability or responsibility for the accuracy, completeness or usefulness of any information, apparatus, product or process disclosed, or represents that its use would not infringe privately owned rights.

The views, opinions and conclusions contained in this report are those of the contractor and do not necessarily represent those of the United States Government or the United States Department of Energy.

PACIFIC NORTHWEST LABORATORY

operated by

BATTELLE

for the

UNITED STATES DEPARTMENT OF ENERGY

Under Contract EY-76-C-06-1830

$\because$ 


\section{5}

PNL-2821

THE EFFECTS OF THE BEN FRANKLIN DAM ON THE HANFORD SITE

Harold Harty, Project Manager

Apri1 1979

Prepared for the U.S. Department of Energy under Contract EY-76-C-06-1830

Pacific Northwest Laboratory Richland, Washington 99352 
$\therefore$ 


\section{CONTENTS}

INTRODUCTION

PREVIOUS STUDIES

DAM DESCRIPTION

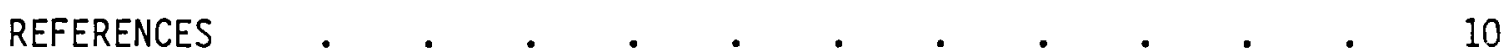

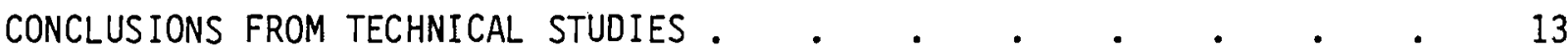

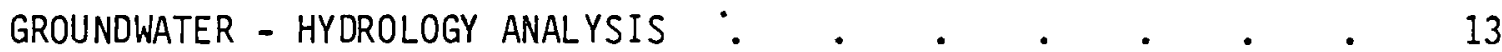

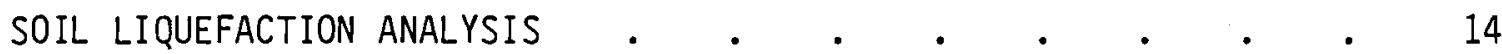

HYDROSTATIC UPLIFT AND SOIL EFFECTS ON STRUCTURES . • • • 15

ASSESSMENT OF POTENTIAL LANDSLIDING AND EROSION $\quad$ • $\quad$ • 16

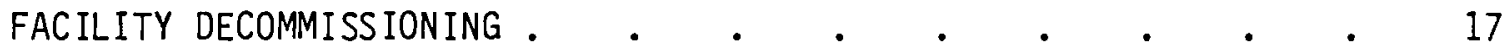

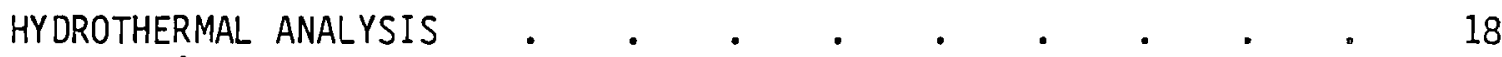

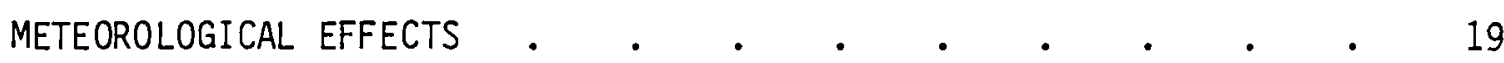

TERRESTRIAL ECOLOGY • • • • • • • • . . . . . 20

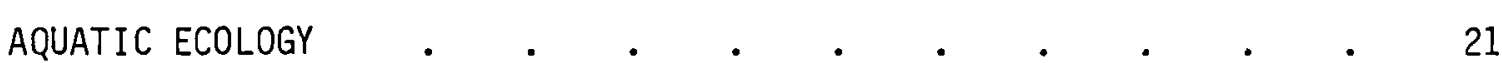

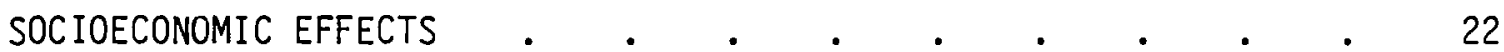

ONGOING DOE R\&D PROGRAMS . . . . . . . . . . . . . . . 22

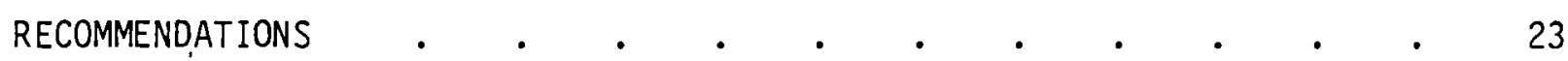

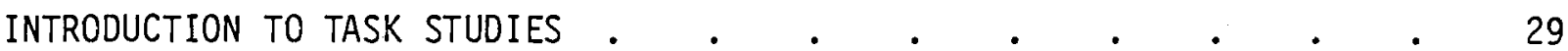

TASK 1: GROUNDWATER - HYDROLOGY ANALYSIS $\quad . \quad . \quad . \quad . \quad . \quad . \quad$. 31

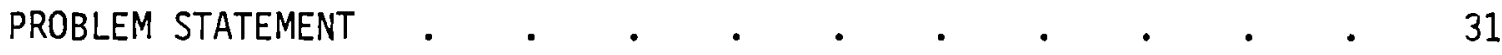

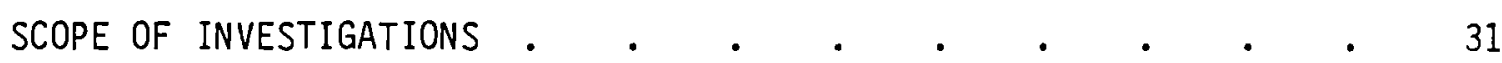

Formulation of the Variable Thickness Transient

Groundwater Code . . . . . . . . . 32

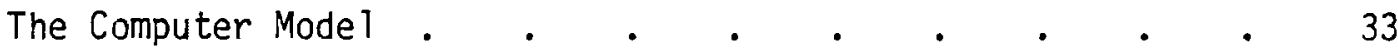

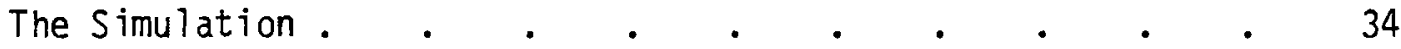




\section{CONTENTS (contd.)}

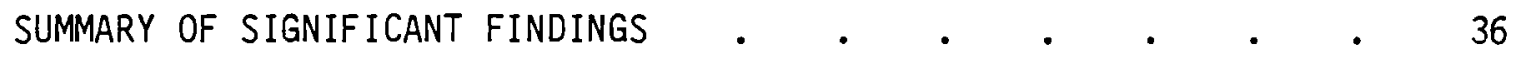

RECOMMENDATIONS . . . . . . . . . . . . . . . 38

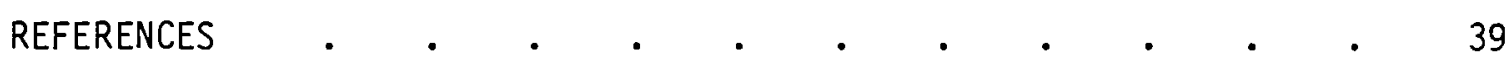

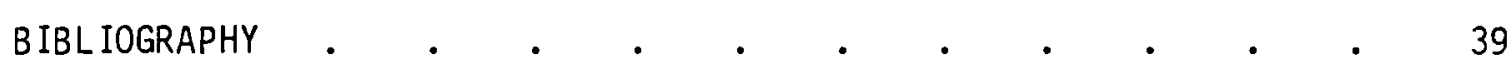

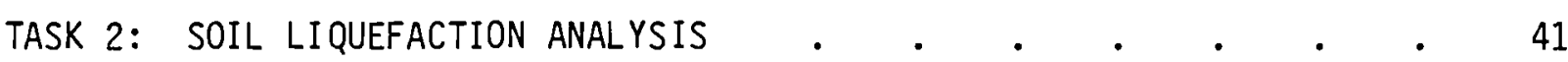

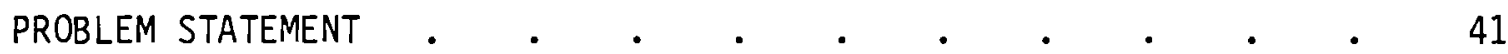

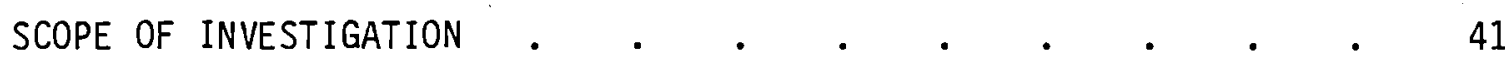

Engineering Considerations in Soil Liquefaction

at Hanford . . . . . . . . . . . 42

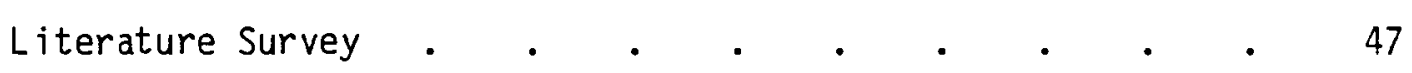

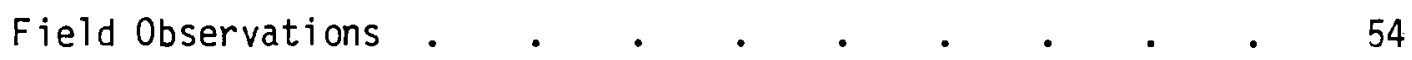

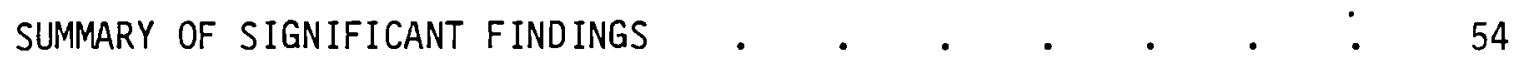

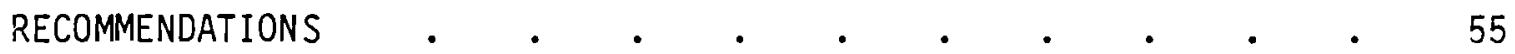

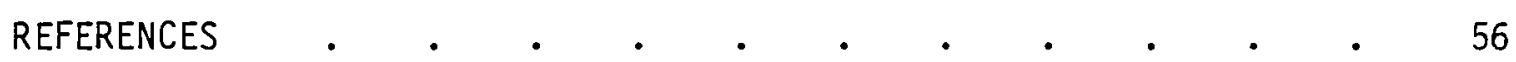

TASK 3: HYDROSTATIC UPLIFT AND SOIL EFFECTS

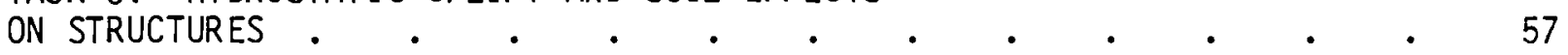

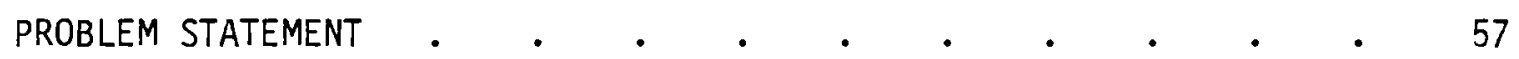

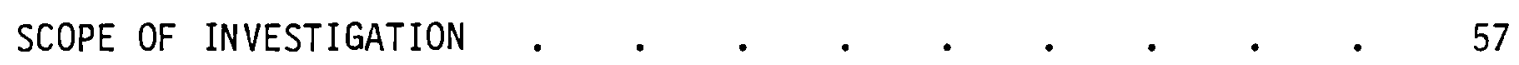

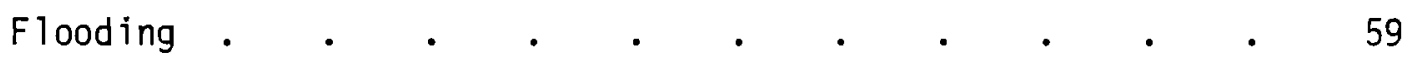

Groundwater Rise $\quad$. $\quad$. $\quad$. . . . . . 62

Bearing Capacity of Structural Foundations . . . $\quad . \quad 62$

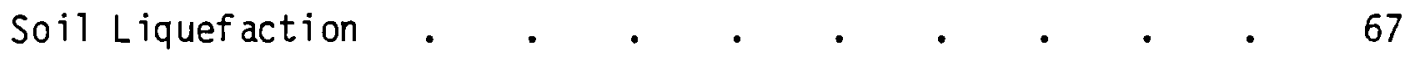

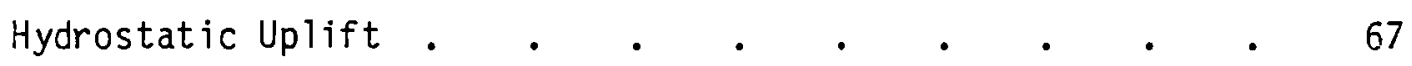

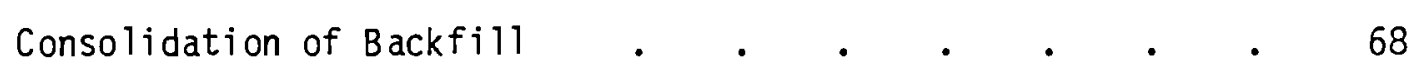

Change in Earthquake Response of Structures . . . . $\quad 69$ 
CONTENTS (contd.)

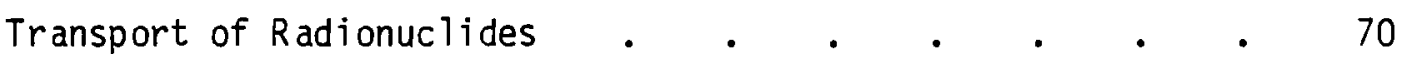

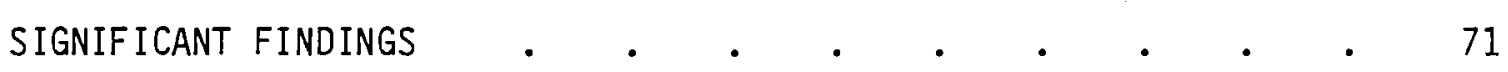

$100-\mathrm{F}$ and 100-H Areas . . . . . . . . . . 71

100 Area Effluent Lines . . . . • • • • 72

Soil Liquef action Potential and Earthquake

Response, 100-B, K, and D Areas . . . . . . 72

Contaminated Lines in Backfill . . . . . . . 73

Other Areas - 200-E, 200-W, 300 and 400 Areas . . . 73

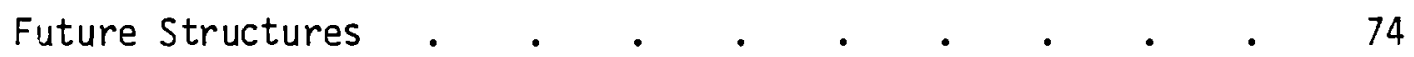

RECOMMENDATIONS .

Flooding . . . . . . . . . . . . . 74

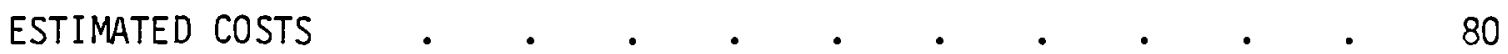

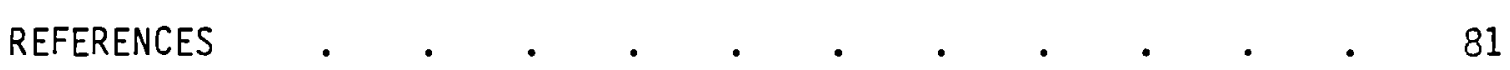

TASK 4: ASSESSMENT OF POTENTIAL LANDSLIDING

AND EROSION $\cdot$ •

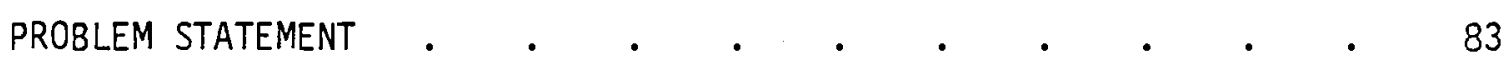

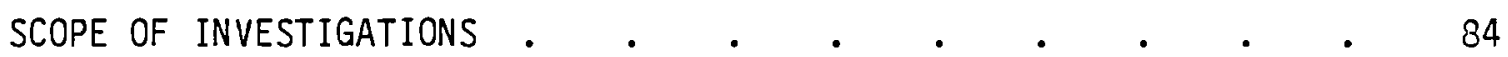

Review of Earlier Studies . . . . . . . 87

Geology of the White Bluffs . . . . . . . . 88

Results of Field Investigations . . . . . . 89

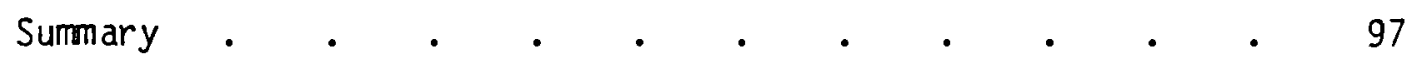

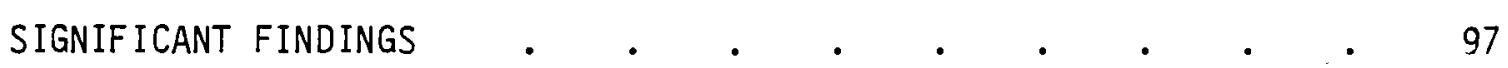

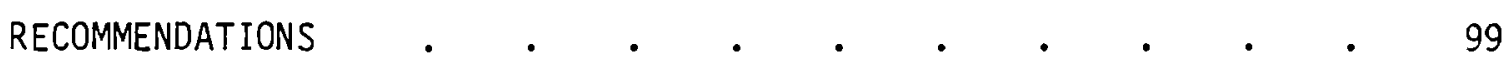

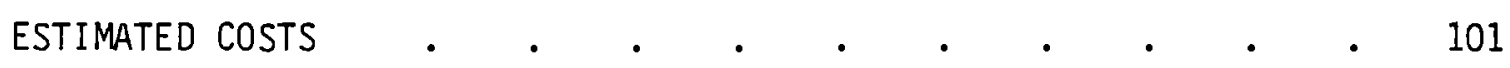

REFERENCES . 
CONTENTS (contd.)

TASK 5: FACILITY DECOMMISS IONING REQUIREMENTS $\quad \cdot \quad \cdot \quad \cdot \quad \cdot 103$

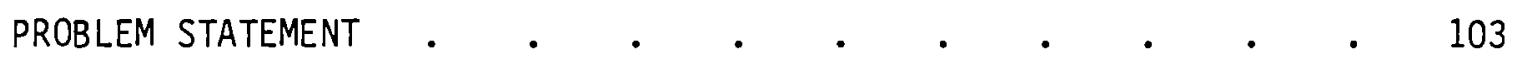

SCOPE OF INVESTIGATION

Decommissioning Criteria. . . . . . . . 105

Projected Reservoir and Groundwater Elevations . . . 113

SIGNIFICANT FINDINGS $\quad \cdot \quad \cdot \quad \cdot \quad \cdot \quad \cdot \quad \cdot \quad \cdot \quad \cdot \quad \cdot 113$

100-F Area . . . . . . . . . . . . . 113

100-H Area . . . . . . . . . . . 128

100-D Area . . . . . . . . . . . 141

100-N Area $. \quad . \quad . \quad . \quad . \quad . \quad . \quad . \quad . \quad . \quad .148$

100-K Area . . . . . . . . . . . . 148

100-B Area . . . . . . . . . . . 155

600 Area . . . . . . . . . . . . . 164

SUMMARY OF SIGNIFICANT FINDINGS

RECOMMENDATIONS $\cdot$.

REFERENCES •

TASK 6: HYDROTHERMAL ANALYSIS $. \quad . \quad . \quad . \quad . \quad . \quad . \quad .175$

PROBLEM STATEMENT $•$ •

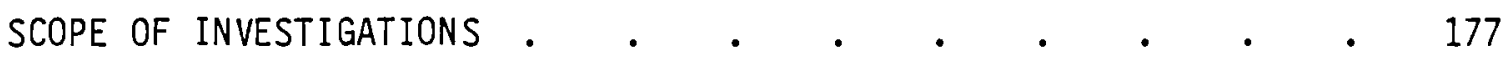

Water Temperature Investigation . . . . . . 177

Near Field Dilution of HNEC Effluent Plumes . . . . 185

SIGNIFICANT FINDINGS $\quad \cdot \quad \cdot \quad \cdot \quad \cdot \quad \cdot \quad \cdot \quad \cdot \quad \cdot \quad \cdot 188$

RECOMMENDATIONS $. \quad . \quad . \quad . \quad . \quad . \quad . \quad . \quad . \quad . \quad . \quad 189$

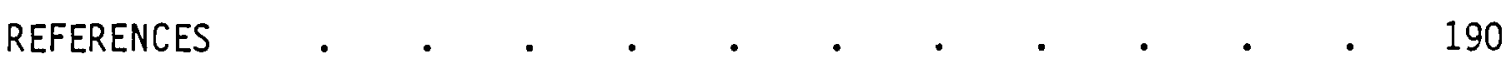


CONTENTS (contd.)

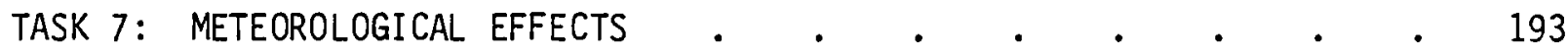

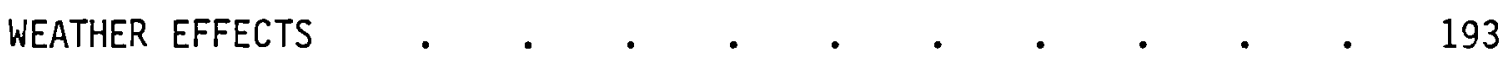

Problem Statement . . . . . . . . . . . 193

Scope of Investigation $\quad . \quad$. $\quad . \quad$. $\quad . \quad$. 194

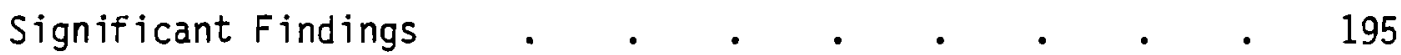

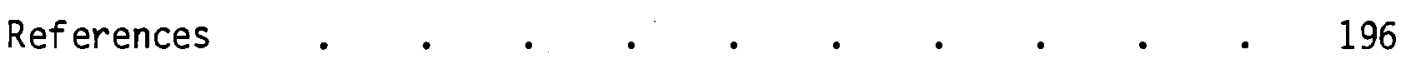

SUSPENSION OF RADIOACTIVE MATERIAL FROM BURIED WASTE

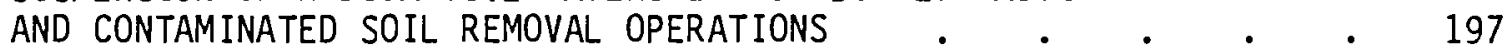

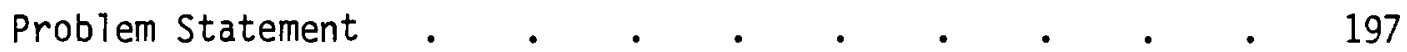

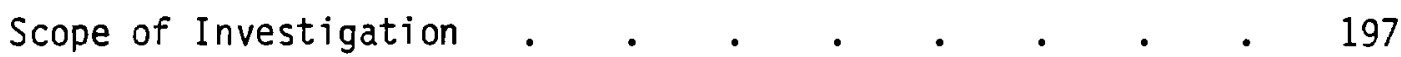

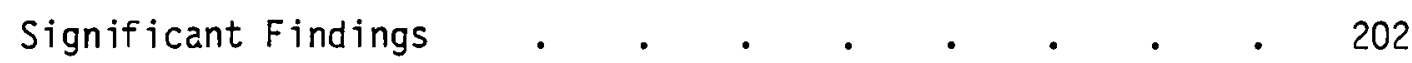

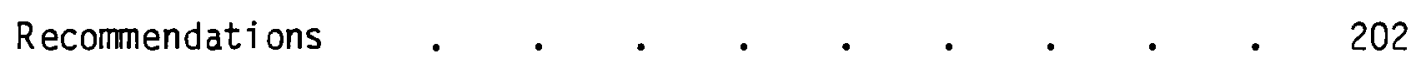

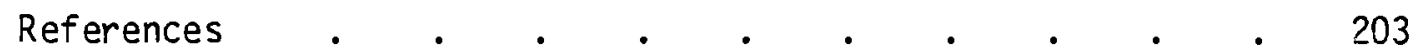

TERRESTRIAL ECOLOGY

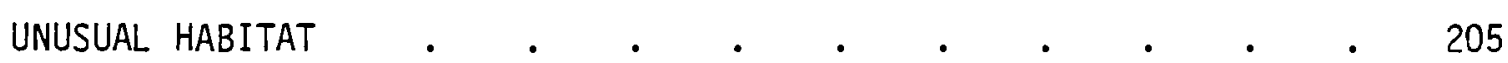

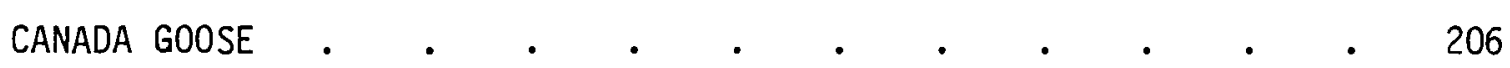

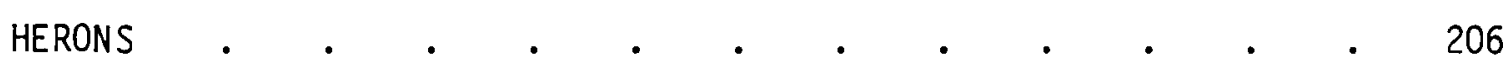

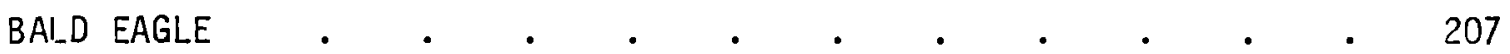

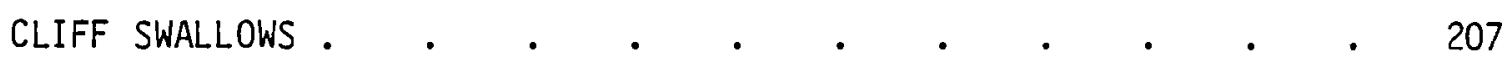

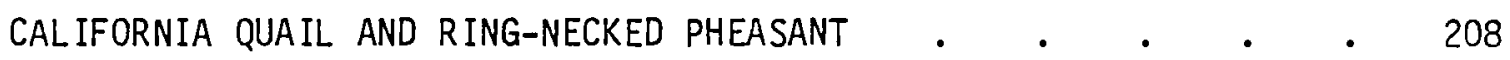

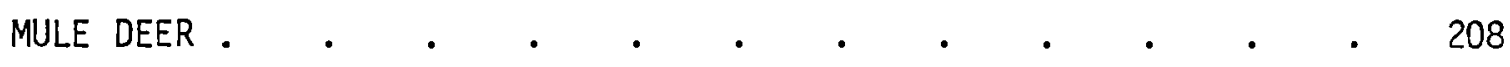

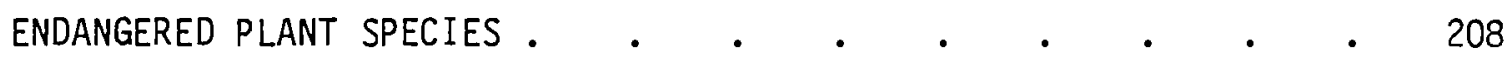

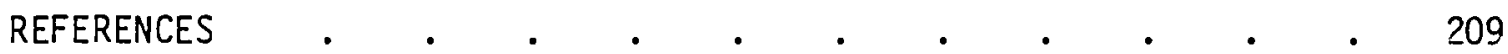




\section{CONTENTS (contd.)}

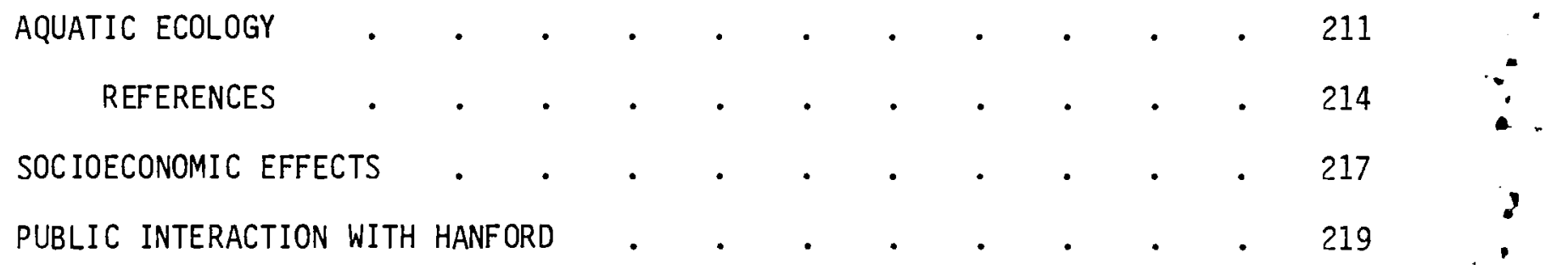




\section{FIGURES}

1 Hanford Site Showing Location of Ben Franklin Dam

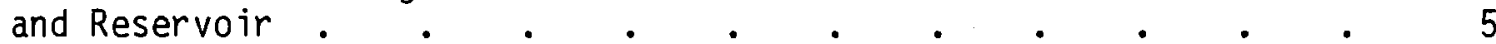

2 Plan of Ben Franklin Dam . . . . . . . . . . . . 6

3 Predicted Water Table Resulting from Ben Franklin Dam 400 Foot Pool . . . . . . .

4 Predicted Water Table Rise for Ben Franklin Dam with 400 Foot Pool . . . . . . . . . . . . 37

5 Range of Values of $r_{d}$ for Different Soil Profiles . . . 47

6 Historic Occurrences of Liquef action . . . . . . . . . $\quad$. 48

7 Predicted Water Table Contours 400-Foot Ben Franklin Pool Elevation 300,000 cfs Flow, 100-F Area . . . . . 60

8 Predicted Water Table Contours 400-Foot Ben Franklin Pool Elevation 300,000 cfs Flow, 100-H Area . . . . . 51

9 Predicted Water Table Contours 400-Foot Ben Franklin Pool Elevation 300,000 cfs Flow, 100-BC Area . . . . .

10 Predicted Water Table Contours 400-Foot Ben Franklin Pool Elevation 300,000 cfs Flow, 100-K Area . . . . . 64

11 Predicted Water Surface Contours 400-Foot Ben Franklin Pool Elevation 300,000 cfs Flow, 100-N Area . . . . .

12 Predicted Water Table Contours 400-Foot Ben Franklin Pool Elevation 300,000 cfs Flow, 100-D Area . . . . . . 66

13 Location Map Showing Area Covered by Figure $14 \quad$ • $\quad$ • . . 85

14 Landslide and Groundwater Seepage Locations as Mapped from Aerial Photograph . . . . . . . . 86

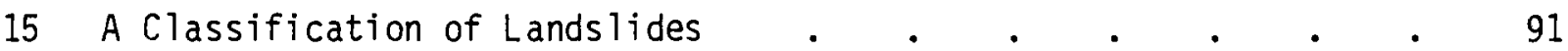

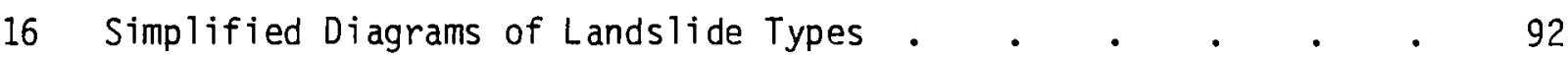

17 Cross Section Showing Approximate Relationship of Wasteway Pond Seepage, Weak Clay Layer, and Proposed Reservoir Level . . • • • • • • •

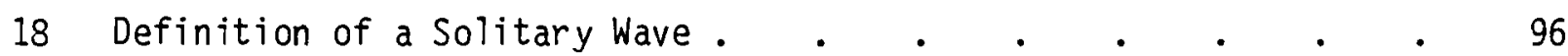


FIGURES (contd.)

19 Effluent System, D and DR Reactors . . . . . . . . 142

20 100-K Area and Washouts . . . . . . . . . . . . 152

21 Reactor Retention Basin System, B and C Reactors . . . . 159

Natural River and Reservoir Water Surface Elevation
Changes Under Different Flow Conditions

23 Predicted Variation in Daily Water Temperatures Under Natural and Reservoir Conditions with No Heated Discharges - 1975

Hydrologic and Meteorologic Base Conditions . • . . $\quad$. 182

24 Predicted Variation in Daily Water Temperatures Under Natural and Reservoir Conditions with HNEC Discharges - 1975

Hydrologic and Meteorologic Base Conditions . . . . . 183

25 Schematic of Processes Involved in Population Dose

from Two Removal Activity Options, Illustrated

with an Exaggerated Vertical Scale . $. \quad . \quad . \quad . \quad . \quad . \quad 199$ 


\section{$\underline{\text { TABLES }}$}

1 Summary of Estimated Cost of Task Recommendations . . . . . 25

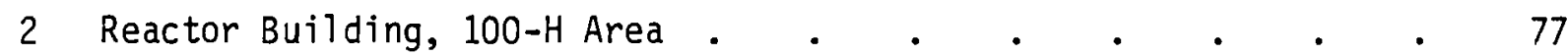

3 Buildings in 100-H Area Near or Below Anticipated Groundwater

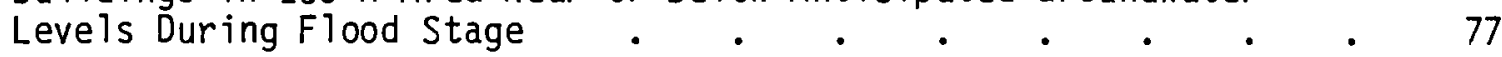

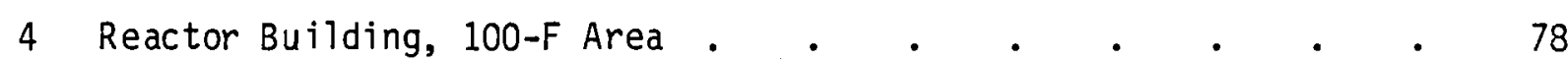

5 Buildings in 100-F Area Near or Below Anticipated Groundwater

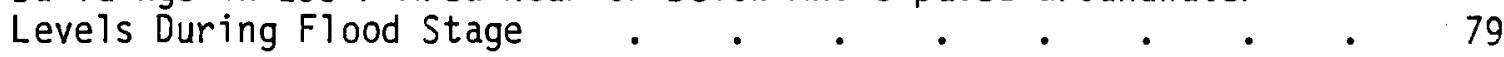

6 Hanford Production Area Current Status . . . . . . . 104

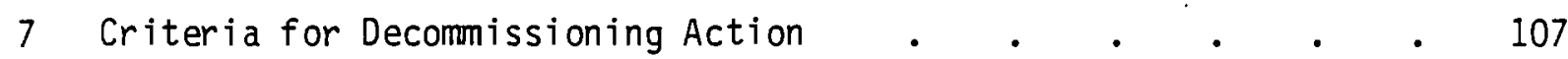

8 Projected Reservoir and Groundwater Elevations

9 100-F Area Facilities Potentially

Requiring Decommissioning . . . . . . . . . . 115

10 Effects of Ben Franklin Reservoir on

11 Decommissioning Activities and

$12 \quad$ 100-H Facilities Potentially

13 Effects of Ben Franklin Reservoir on 100-H Area Facilities. . . . . . . . . . . . . . 133

14 Decommissioning Activities and Estimated

15 Facilities Potentially Requiring Decommissioning - 100-D Area . . . . . . . . . 143

16 Effects of Ben Franklin Reservoir on
$100-$ F Area Facilities . $\quad . \quad \ldots$
.

17 Decommissioning Activities and Estimated

$18 \quad 100-N$ Facilities Potentially Affected by a 400-Foot Reservoir . . . . . . . . . 
TABLES (contd.)

19 Facilities Potentially Requiring

Decommissioning - 100-K Area . . . . . . . . . . 151

20 Effects of Ben Franklin Reservoir

on 100-K Area Facilities. . . . . . . . . . . . 153

21 Decommissioning Activities and Estimated

22 100-H Facilities Potentially Requiring

Decommissioning 100-B Area

23 Effects of Ben Franklin Reservoir

on 100-F Area Facilities. . . . . . . . . . . 160

24 Decommissioning Activities and Estimated

Costs - 100-B Area . . . . . . . . . . 163

25600 Area Facilities Potentially Affected

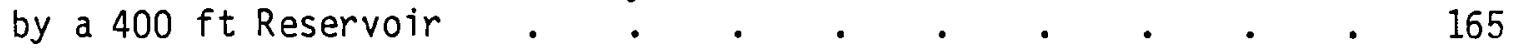

26 Summary of Decommissioning Costs Required

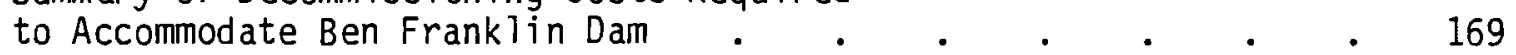

27 Predicted Average Monthly Water Temperatures at Richland for Each Case

28 Excess Effluent Temperatures 121,000 cfs River Flow 


\section{INTRODUCTION}

A previous assessment of the effects of a Ben-Franklin Dam on the Hanford Site was made in 1967. The Department of Energy, Richland Operations Office (DOE-RL), has requested the Pacific Northwest Laboratory to update the previous assessment so that the potential adverse effects may be better understood in light of existing operations, current environmental and safety standards, and proposed facilities and operations.

The major effects would probably arise from flooding of portions of the site by the reservoir associated with the dam and by the raising of the ground water table under the site.

This report presents a preliminary analysis of the effects of the dam and recommends that a number of studies be accomplished to fully evaluate and understand these potential impacts.

\section{STUDY GUIDELINES}

Seven tasks were identified by DOE-RL:

1. Groundwater - Hydrology Analysis

2. Soil Liquefaction Analys is

3. Hydrostatic Uplift and Soil Effects on Structures

4. Assessment of the Potential for Landsliding and Sloughing

5. Facility Decommissioning

6. Hydrothermal Analys is

7. Meteorological Effects.

Further, DOE-RL requested that a listing be made of other aspects that should be studied, together with knowledgeable opinions about them. Four aspects are commented upon in this report: aquatic ecology, terrestrial ecology, socioeconomic effects, and public interaction. Possible effects on ongoing DOE-sponsored R\&D are also noted.

To the extent possible, cost estimates are developed for corrective actions which must be taken on the Hanford Site to accommodate the dam. Where this was not possible, appropriate courses of action leading to cost estimates are presented. 


\section{PREVIOUS STUDIES}

A previous assessment of the effects of a Ben Franklin Dam on the Hanford Site was made in 1967 . The results were reported in three documents:

1. DUN-2349, Ben Frank lin Dam Study, Final Report I (Ballowe 1967)

This study addressed three major program areas: 1) evaluating the general dispersion characteristic of the reactor effluent plumes under reservoir conditions and possible effect on plant inlet water temperatures, 2) determining whether or not the heated effluent might recirculate into the intake of the reactor plant or into the intake of an adjacent reactor plant, and 3) investigating the effect of an elevated groundwater table on 100 Area facilities and structures. Ecological considerations and the effects on the Washington Public Power Supply System installation at 100-N Area were excluded from the study.

The Ballowe study concluded that, for a Ben Franklin Dam with a 400-foot reservoir (the elevation presently planned):

- No significant effect would be expected on facility foundations; however, at $100-F$ and $\mathrm{H}$ Areas, where the predicted $r$ ise in water table is the greatest, and will extend to, or above, some of the footings, it appears prudent to provide for monitoring building foundation settling in these areas.

- Major effects of the elevated groundwater table are associated with the radioactive material burial grounds in $100-F$ and $H$ Areas, and the proposed waste management emergency crib in 100-N Area. At the present stage of the Ben Franklin Dam study program, it is considered that removal of critical buried wastes may be necessary, and an alternate concept or modified design for the 100-N waste disposal system appears to be required. Provisions for this corrective action are included in the cost estimates, with a final decision as to its necessity being reserved until a later stage. 
- Some galleries and basins in the $105-\mathrm{H}$ and $\mathrm{F}$ Buildings (reactors) may require protection against hydrostatic uplift. The effluent retention basins in both $100-F$ and $H$ Areas may require additional protection from hydrostatic uplift.

- The estimated corrective cost estimate.... is $\$ 3,800,000$.

2. BNWL-412, The Effects of Ben Frankl in Dam on Hanford (Haney 1967)

The Haney report addressed the groundwater regime as influenced by the reservoir, and the effect on radionuclides in the vadose zone from the reservoir. The former presented water table contour maps and flow system analyses as affected by reservoir levels and river flow rates. The latter reviewed the sites of radioactive materials in each of 200-E, 200-W, P-11, Gable Mountain, and B-Plant swamps with respect to potential water table interactions. It concluded that no significant adverse or untenable effects would result, insofar as radioisotopes stored in the vadose zone are concerned, from the proposed construction of the Ben Frank7in Dam.

3. BNWL-733, A Preliminary Evaluation of the Thermal Effects of the Ben Frank 7 in Dam Project on Columbia River Temperatures Be low the Hanford Plant, (Jaske 1968)

The objective of the Jaske report was to determine the effects of the Ben Franklin Dam on Columbia River temperatures. Using the plant operations record for 1966, and the weather record for the same period, a series of simulation runs was made to determine the effects of the dam on the temperature regime, and the extent to which density currents could be expected to develop. The report concluded that the proposed project would have nominal effect, tending toward a slight increase in downstream temperature. Under some conditions, in critical temperature seasons (April and September), plant operations cause amplification of the temperature transients associated with stream regulations and $\mathrm{plant}$ load factor. Density currents could be expected in the reservoir for most of the summer months, thus causing decreased trave 1 time and relatively adiabatic thermal conditions for the main flow system at the lower end of the reservoir. 
Since these three studies were completed, operations at Hanford have changed, additional data on the river and the groundwater systems are available, environmental and safety standards and requirements have changed, and other factors may be involved. With the indication of renewed interest in Ben Franklin Dam, it is appropriate to update the earlier assessments and consider possible new developments, requirements, and concerns that may not have been assessed in 1967.

\section{DAM DESCRIPTION $(a)$}

The Ben Franklin site lies at the head of McNary Reservoir (Lake Wallula), RM 348, 10 miles upstream from Richland, Washington (Figure 1). The 49-mile reach of river affected lies mainly in Benton and Franklin Counties. Grant County borders the upper 25-mile portion of the left bank. Most of the reservoir would be within the Hanford Reservation. The exception is 7 miles of the left bank (b) upstream from the Ben Franklin site, and short reaches on either bank upstream from Vernita. The dam axis at river mile 348 crosses near the downstream end of the $2 \frac{1}{2}$ mile long "Wooded Island." The channel bottom elevation is about 325 feet above mean sea level.

The Ben Franklin site is in an area where basalt rock of the Columbia Plateau is 160 to 250 feet below the river bottom. Overlying the basalt is a 200 to 225-foot thick deposit of consolidated sediments, consisting of sands, silts, gravel, and clay. These sediments, known as the Ringold Formation, form the cliffs along the left (east) bank at the Ben Franklin site. Locally, overlying the Ringold Formation, is a layer of gravels, cobbles, and boulders 20 to 100 feet thick, deposited by glacial outwash streams. On the right (west) bank, windblown sands cover the glacial flood gravels. The Ben Franklin damsite is in a zone of mild seismicity.

The Ben Franklin Dam would be a low head, run-of-the-river dam having a 16-unit powerhouse, a 15-bay spillway and a navigation lock, all on a straight axis across the river (Figure 2).

(a) Except as noted, the dam description is excerpted from Ben Franklin Lock, Dam, and Reservoir, Columbia River, Washington, Seattle District, U.S. Army Corps of Engineers, Vol. 1, 1969.

(b) The left and right banks are referenced with respect to the downstream direction. 


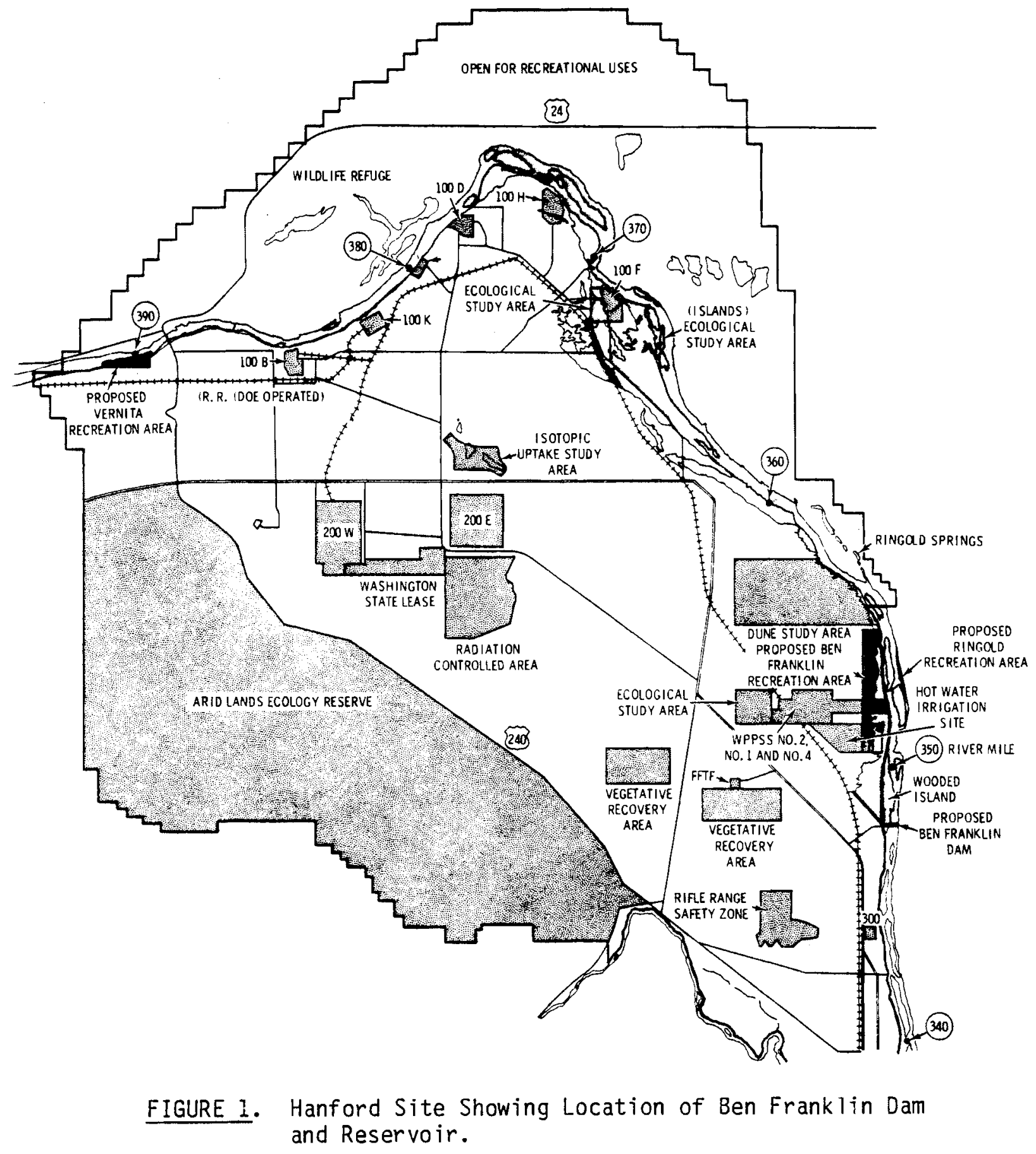




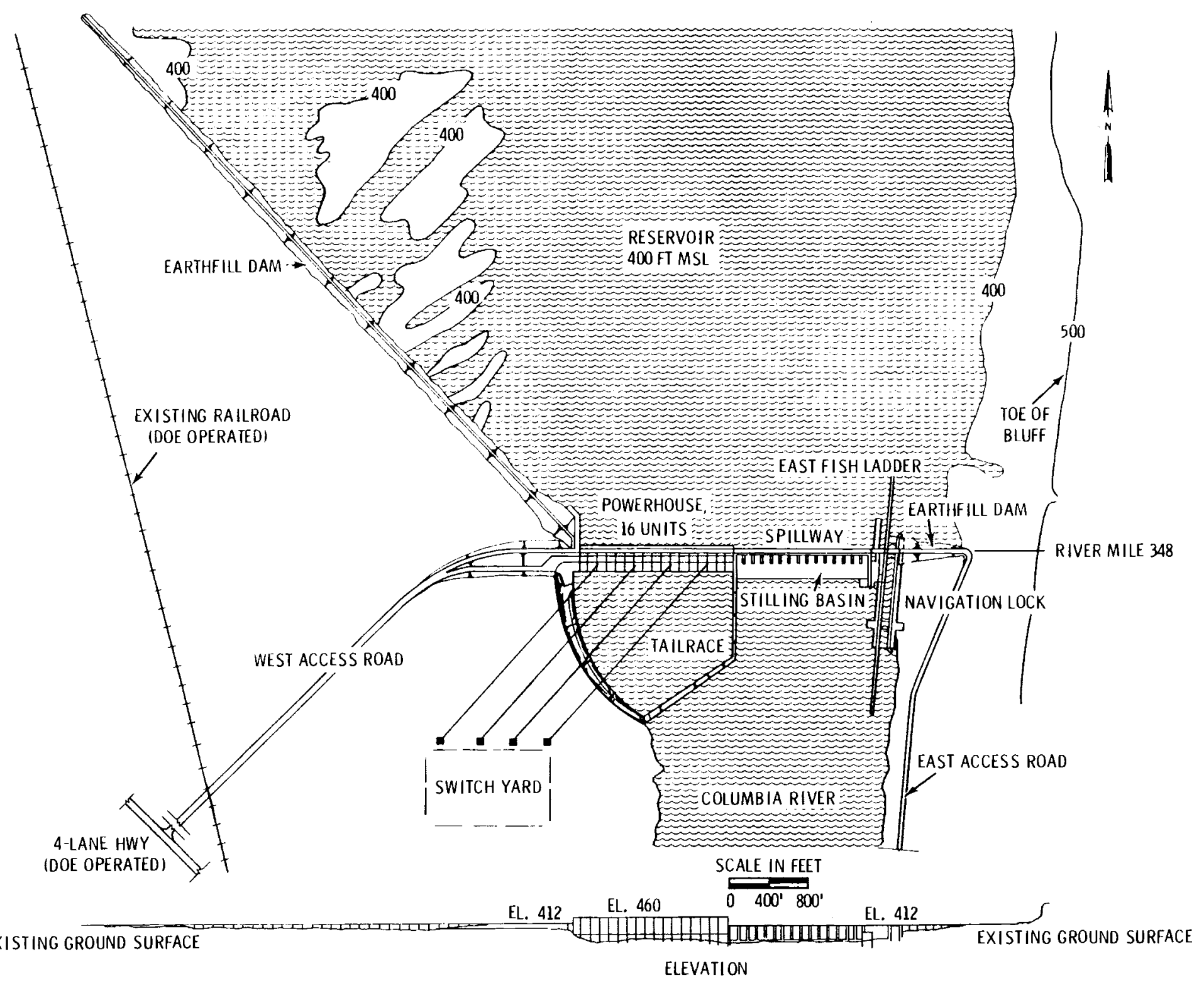

FIGURE 2. Plan of Ben Franklin Dam 
The powerhouse, spillway, fish ladders, and navigation lock would be concrete structures with spread foundations designed for bearing on the Ringold Formation at the damsite. The earthfill dams would connect the concrete dam structure to high ground on both shores of the river. The dam structures would be designed with a 12-foot freeboard above the maximum pool elevation of 400 feet. The navigation lock dimensions would match those on lower Columbia River projects. The lock would be constructed at the left end of the spillway. The fish ladders would be designed on the basis of experience gained at other dams on the Snake and Columbia Rivers. A roadway would extend the full length of the earth and concrete portions of the dam to accomodate operation and maintenance equipment and the visiting public.

The spillway would extend 1,325 feet along the dam axis and would be designed to pass a $1,600,000$ cfs flow with the gates fully open.

The powerhouse would extend 1,564 feet along the dam axis and would be 228 feet wide. The structure would include 16 power-generating bays, each with a vertically-mounted conventional Kaplan turbine with a rated output of 83,600 horsepower at 45 feet rated head connected to a generator with a nameplate rating of $53,000 \mathrm{~kW}$, for a total of $848,000 \mathrm{~kW}$.

The earthfill dams would be about 7,100 feet long on the west shore and 600 feet long on the east shore. They would have impervious silt cores resting on the Ringold Formation, filter zones of selected granular materials, outer layers of random granular materials, and slope protection facings of rock riprap. An asphalt-surfaced roadway would be constructed along the top.

The reservoir would be 49 miles long, cover an area of 24,700 acres, and have a 120-mile shoreline and a normal pool elevation of 400 feet at the dam. The reservoir would inundate 11,500 acres of riparian lands, including about 4,000 acres of the Ringold Unit of the McNary Wildlife Refuge and 15 river islands, 850 acres in area, that provide essential habitat for about 250 deer, 10,000 upland game birds, and 318,000 waterfowl. The riparian lands are vegetated with trees, shrubs, grasses, and forbs. The reservoir in turn would create 16,000 acres of new riparian 1 ands (presently in a semi-desert state) and about 40 new islands, less than 850 acres in total area. Currently, about 
15 islands exist in the same reach. In addition, seven large islands would be formed in the reservoir by limited excavation to isolate seven peninsulas from the main shoreline. The total acreage of the new reservoir islands would amount to approximately 2,500 acres.

Three recreation areas would be provided: a 400-acre site in Benton County, the Vernita Recreation Area, would be on the right shore, $1 \frac{1}{2}$ miles upstream from the highway bridge at Vernita; an 800-acre recreation area in Benton County, the Ben Franklin Recreation Area, would be on the right shore $2 \frac{1}{2}$ miles upstream from the dam; and a 115-acre recreation site in Franklin County, the Ringold Recreation Area, would be on the left shore $4 \frac{1}{2}$ miles upstream from the dam. Camping, picnicking, boat-launching, swimming and parking facilities, and utilities would be provided at each area.

The reservoir land acquisition program would be based on lands required for permanent structures, lands required for a maximum pool elevation of 400 feet above mean sea level and for fish and wildlife mitigative measures. The 300-foot reservoir strip would be required to safeguard against effects of wave action and river bank sloughing, for recreational access, and for archeological exploration. This strip would remain under DOE jurisdiction.

Ownership of the reservoir lands is divided among government, state, and private concerns as shown in the following tabulation:

\begin{tabular}{|c|c|c|c|}
\hline Land Type & $\begin{array}{c}400-\text { Foot } \\
\text { Elevation } \\
\text { (acres) } \\
\end{array}$ & $\begin{array}{l}300-\text { Foot } \\
\text { Strip } \\
\text { (acres) } \\
\end{array}$ & $\begin{array}{c}\text { Total } \\
\text { acreage } \\
\end{array}$ \\
\hline Government lands & 13,507 & $100^{(a)}$ & 13,607 \\
\hline \multicolumn{4}{|l|}{ State lands } \\
\hline Existing riverbed & 10,200 & -- & 10,200 \\
\hline Riparian lands & 215 & -- & 215 \\
\hline Private 1 ands & 778 & $\underline{300}$ & 1,078 \\
\hline Totals & 24,700 & 400 & 25,100 \\
\hline
\end{tabular}

(a) Does not include Federal lands to be retained under DOE jurisdiction. 
This gives a total project requirement for lands of 25,100 areas. The Department of Energy has jurisdiction over the entire 13,607 acres of government 1 ands.

Two-stage diversion of the river would be required to construct the dam. The work would begin with a first-stage cofferdam, which would encompass the navigation lock, east fish ladder, east earthfill dam section, and a portion of the spillway. The powerhouse, remainder of the spillway, west earthfill dam, and the west fish ladder would be constructed during the second stage. River velocities during the first-stage diversion would permit the passage of fish without special provisions. However, the east fish ladder would be required to pass migrating fish during second-stage construction and a temporary fish passage facility would be provided adjacent to the second-stage cofferdam as required.

Four years for preconstruction planning and 10 years for acquisition and construction, or a total of 14 years, would be required for completion of the project after the initial appropriation of funds. Approximately 7 years would elapse from the commencement of construction to the first power on line. The schedule starts with selection of the exact dam axis while concurrently determining the size and number of generating units. Following site selection a general design memo would be prepared and model studies of the spillway and stilling basin would start. Other design memoranda, plans and specifications, and construction would follow in sequence. 
The estimated cost of recommended improvements including contingencies, based on January 1968 costs, is shown in the following tabulation:

\begin{tabular}{l} 
Item \\
\hline Lands and Damages \\
Site and reservoir lands \\
Recreation lands \\
Fishery mitigation \\
Relocations \\
Reservoir \\
Dam \\
Lock \\
Fish and Wildlife \\
Powerplant \\
Roads, Railraods, Bridges \\
Recreation facilities \\
Bldgs., etc. \\
Perm. Op'g Equip. \\
Subtotal \\
E\&D, S\&A \\
Total initial constr. cost, financial \\
Future Recreation \\
Total constr. cost, financial
\end{tabular}

\begin{tabular}{rr} 
Estimated Costs \\
\hline$\$ 937,000$ \\
183,000 \\
63,500 & $1,183,500$ \\
& \\
& $10,350,000$ \\
80,000 \\
$61,600,000$ \\
$20,630,000$ \\
$25,054,000$ \\
$145,100,000$ \\
$1,200,000$ \\
$1,620,000$ \\
552,000 \\
236,000 \\
$\$ 267,605,500$ \\
$30,894,500$ \\
$\$ 298,500,000(a)$ \\
$\frac{3,500,000}{\$ 302,000,000}$
\end{tabular}

(a) Excludes the $\$ 217,000$ market value of Federal lands, and preauthorization costs of $\$ 965,000$.

PNL estimates that a peak work force of about 1500 to 2000 would be employed in the construction of the dam and associated facilities. The peak work force would continue for about 3 years of the 6 to 7 -year construction period. 


\section{REFERENCES}

Ballowe, J. W. 1967. Ben Franklin Dam Study Final Report I. DUN-2349, Douglas United Nuclear, Inc., Richland, WA 99352.

Haney, W. A., ed. 1967. The Effects of Ben Franklin Dam on Hanford. BNWL-412, Pac if ic Northwest Laboratory, Richland, WA 99352.

Jaske, R. T. 1968. A Preliminary Evaluation of the Thermal Effects of the Ben Frank lin Dam Project on Columbia River Temperatures Below the Hanford Plant. BNWL-733, Pacific Northwest Laboratory, Richland, WA 99352. 


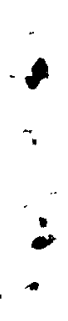

3

* 


\section{CONCLUSIONS FROM TECHNICAL STUDIES}

This section highlights the major conclusions from each of the seven study tasks. Recommended further studies in the four additional aspects investigated are also listed.

GROUNDWATER - HYDROLOGY ANALYSIS

The reservoir created by Ben Franklin Dam will raise the groundwater level throughout the Hanford Site. Increases will range from 8 to 16 feet under the 200 Area plateau to those which will interact with buildings and structures and radioactive materials burial sites in 100-F and $H$ Areas. The increase in groundwater table under the 200 Areas is not considered significant with respect to interactions with radioactive wastes in those areas.

Generally the water table in the other 100 Areas will be lower than predicted from previous studies; thus, these areas will probably require relatively minor corrective actions to accommodate the Ben Franklin Dam. However, an area-by-area groundwater analysis will be required. Typical analyses will consist of drilling two to three shallow test borings per disposal site, sampling radioactive contaminants, and evaluating findings with a transport model to determine need for corrective action.

The caisson storage units at the Wye burial ground (318-11) may be affected by elevated groundwater levels.

Other areas, including the 300 and 400 Areas, are not significantly affected by increased groundwater levels.

Existing groundwater data are not sufficient to predict changes in the water table on the left (east) bank (the Wahluke Slope area) as a result of Ben Franklin Dam.

The higher water table will tend to shorten some groundwater flow paths and increase others from the 200 Areas, changing radioactive material transport times to the river in the groundwater system. The changes are not considered significant. 
A number of burial grounds in $100-F$ and $H$ Areas and contaminated soils in $100-\mathrm{B}, 100-\mathrm{K}, 100-\mathrm{D}, 100-\mathrm{H}$, and 100-F Areas are within the bank storage area affected by the backwater fluctuations behind the dam. During times of pool drawdown, groundwater gradients will increase and cause rapid water movement through burial grounds and areas where radionuclides have been stored on the soil.

A combined hydrologic and geologic characterization of the left bank of the Hanford Site is required to permit more definitive analysis of the stability of the Wahluke Slope under present conditions, as well as with Ben Franklin Dam. Data from existing wells and an additional estimated five wells (these will include data on physical and chemical characteristics of the soils), together with a modeling/analytical effort, are needed for proper evaluation.

\section{SOIL LIQUEFACTION ANALYSIS}

Liquefaction potential is normally precluded by soil compaction, which is also required to prevent foundation settling. Soil liquefaction under earthquake conditions for major 100 Area facilities appears unlikely. However, it is prudent to verify the liquefaction potential with test borings, including up-to-date triaxial compression and simple shear tests, especially for facilities that will experience significant interactions with the groundwater. Especially affected are the $105-F$ and $H$ structures and associated stacks.

The left bank of the river in the vicinity of the White Bluffs currently has a very high probability of soil liquefaction under minor earthquake acceleration. The Ben Franklin Dam will likely increase the probability only marginally. The likely effect of an earthquake is to cause a massive earthflow into the Columbia River.

Liquefaction does not normally occur below about 50 to 60 feet (irrespective of the location of the water table) due to overburden pressure. Thus, the 200 and 400 (FFTF) Areas will not experience liquefaction-related problems as a result of Ben Franklin Dam, since the water table will be below those depths. 


\section{HYDROSTATIC UPLIFT AND SOIL EFFECTS ON STRUCTURES}

By far, the greatest effect of the Ben Franklin Dam on DOE structures at Hanford is the flooding of $100-F$ and $100-H$ Areas. The foundations of many buildings, including the reactor buildings, water treatment buildings and retention basins will be below the groundwater level. Others would be in danger of being inundated by rising waters during flooding periods. If 105-F and $H$ and their associated stacks and other major buildings are not dismantled, then, as a minimum, it will be necessary to monitor the settlement of the reactor buildings and other structures; basins, pump wells, and similar structures should be filled with earth to protect against hydrostatic uplift.

A potential source of radioactive contamination, which could be released upon building Ben Franklin Dam, exists in those parts of reactor cooling water effluent lines from the retention basins to the river that will be lower than the predicted groundwater levels. These lines are open to the river and normal pool fluctuations will tend to wash particles down the lines into the river. The disturbance of removing the outfall lines buried in the river bottom could introduce more radioactive materials into the river than the alternative of leaving them in place.

Another potential source of radioactive contamination is radioactive pipe lines laid on backfill, which can become saturated as a result of Ben Franklin Dam. Typically this includes the cooling water effluent lines, other waste water such as drains from the storage basin overflows, wash pad area and waste lines from other decontamination operations. These pipe lines will tend to break should the backfill settle. The present study indicates that on $7 y$ lines in $100-F$ and $100-H$ Areas would be affected.

The effect on structures in the 200 Areas of the groundwater changes is judged to be insignificant.

In the 300 Area, the groundwater rise is predicted to be less than 2 feet, which would have a negligible effect on structures. Also, the rise of about 20 feet to 400 feet elevation at the 400 Area (FFTF) where the ground 
elevation is about 550 feet, leaves about 67 feet from the groundwater to the lowest foundation. It is judged that the effects on structures there would also be insignificant.

Future structures built at Hanford may have to contend with a higher groundwater level should Ben Franklin Dam be built. At higher elevations there will be little or no effect; nearer the river incremental costs for additional foundation work could approach $\$ 2,000,000$, as in the case of WNP 1 and 4. Perhaps more important is the fact that the additional work required is critical path work. It should also be noted that the additional work will always be required as long as the possibility of a Ben Franklin Dam exists.

The effect of the probable maximum flood $(1,440,000$ cfs $)$ on Hanford with Ben Franklin Dam was not evaluated. Approximate flood levels had been previously estimated without the dam and showed flooding of part or all of each 100 Area except 100-B. (a)

\section{ASSESSMENT OF POTENTIAL LANDSLIDING AND EROSION}

Currently, landslides are occurring on the left bank, and have caused the bluff line to recede about 200 to 300 feet, leading to minor turbidity in the river. The slides are due to groundwater seepage forces and wetting of the soil mass. The Ben Franklin Dam will tend to worsen this condition by further weakening the clay layer by increased saturation.

Conditions now exist for a massive slide to occur under earthquake loadings. The slide could block the river channel temporarily and ride up the opposite bank. The Ben Franklin Dam will tend to increase the probability of a massive slide.

(a) Three river flow rates are used in this report:

1. 1,440,000 cfs--the regulated probable maximum flood for the Hanford Reach.

2. 570,000 cfs--the regulated standard project flood, which is approximately equal to the estimated 100-year regulated flood in the Hanford Reach.

3. 300,000 cfs--a typical maximum flow occurring approximately every decade which would be sustained long enough, a month or more, to affect groundwater levels at the Hanford Site. 
No significant erosion or slide problem has been identified along the right bank of the river.

If the rapid large-scale slide were to take place with the Ben Franklin Dam reservoir filled, a solitary wave would be generated in the river channel and would move both upstream and downstream. Based on a number of assumptions, a pressure-generated wave would travel to the damsite at an estimated maximum velocity of 30 miles per hour, assuming no resistance losses. No significant Hanford Site damage would result from the wave action.

\section{FACILITY DECOMMISSIONING}

Construction of the proposed Ben Franklin Dam and reservoir will adversely impact over 60 contaminated facilities at Hanford. These include all facilities at 100-F Area, all facilities except two burial sites and several minor structures at 100-H Area, and portions of the reactor effluent. retention and discharge systems at 100-D, 100-K, and 100-B Areas. Effects on the 116-N-1 crib and trench at 100-N Area are not known at this time.

The 116-N-1 emergency trench and crib contain the largest inventory of radionuclides in facilities of this nature in the 100 Areas, estimated at $4000 \mathrm{Ci}$. As reported in ERDA 1538, the annual discharges to the river due to a saturated soil column from the crib (and from the outfall pipeline) have been reduced to less than $200 \mathrm{C} i$ tritium and $15 \mathrm{Ci}$ of all other radionuclides. The proposed reservoir could exacerbate this situation. The matter requires further study.

Release criteria(a) for contaminated soils and radioactive wastes that will be exposed to groundwater by the proposed reservoir must be determined for individual facilities. Release criteria can be established by determining the potential dose to the maximum exposed individual resulting from release of the facility inventory to the environment. Rates of release can be determined by assessing the radioactivity on the soils and wastes within facilities, the potential for leaching in the groundwater environment, and the rate of

(a) Defined on p. 127. 
transport of leachate to the river. Only when acceptable release criteria are determined can accurate estimates of the extent and cost of soil and waste removal be made.

The proposed reservoir would flood portions of the 100-K Area effluent piping and the 1908-K river outfall structure, requiring, as a minimum, sampling of the internal contamination of these facilities and decontamination. However, the effects of the reservoir on operations of the $100-K$ Area effluent discharge system are not known. If it is intended to maintain the $K-R e a c t o r s$ in standby status following construction of the proposed dam it will be necessary to examine the effects of the reservoir on operation of the effluent discharge system.

HYDROTHERMAL ANALYSIS

Under relatively low streamf low conditions, normal meteorological conditions and current Columbia River system operations (similar to those which occurred in 1975) construction of the proposed Ben Franklin Dam will result in an increase in water temperatures over natural conditions of approximately $0.4 \mathrm{C}(0.7 \mathrm{~F})$ in summer and $0.1 \mathrm{C}(0.2 \mathrm{~F})$ or less in winter. Under more extreme meteorological and streamflow conditions, water temperatures may exceed the $20 \mathrm{C}(68 \mathrm{~F})$ Washington State standard for the Hanf ord Reach.

This increase in temperature can be compared to that resulting from a Hanford Nuclear Energy Center (HNEC). With six once-through cooled nuclear reactors and 14 closed-cycle system reactors discharging a total thermal load of 15,000 MWt, water temperatures would be raised by approximately $1 \mathrm{C}(1.8 \mathrm{~F})$ throughout the year. Under the hydrologic and meteorologic conditions studied (calendar year 1975), the combination of the two facilities would result in the temperature standards being violated frequently during summer months.

The increases in water temperature caused by Ben Franklin Dam could limit or even preclude the use of once-through cooling systems at HNEC facilities, particularly since the combined effects of HNEC thermal discharges and Ben Franklin Dam are an increase in average water temperatures during the period 
from March to August and an increase in the duration of water temperature standards violations. While once-through cooling may not be presently contemplated for present thermal plants, an HNEC may require it to maintain atmospheric effects within acceptable limits. This situation creates the potential for competition between Ben Franklin Dam and HNEC power plants for the remaining thermal carrying capacity of the Hanford Reach.

While the occurrence of vertical thermal stratification in the reservoir created by Ben Franklin Dam is not highly likely, such conditions are possible and could exacerbate water temperature problems as well as create other water quality problems. Within the scope of the work performed, the probability of occurrence for thermal stratification was not quantified.

Near-field mixing of HNEC reactor effluents is rapid when high initial dilution multiple port diffusers are employed. Employing such a diffuser results in downstream temperatures which vary little during average flow conditions. State mixing zone standards would likely be satisfied under average conditions for either natural or reservoir flows.

\section{METEOROLOGICAL EFFECTS}

The proposed Ben Franklin Dam will have minimal effect on altering the meteorological conditions (fogging, icing) and, in turn, disrupting activity on the Hanford Site. Although the evaporation of the impounded water is three times larger than for natural conditions, the moisture will be relatively well dispersed. With strong winter inversions predominating over the valley to inhibit vertical diffusion of the moisture, and light winds characteristic of nocturnal cooling (radiation) fogs, the effect of the excess moisture would probably be a localized increase in the thickness and duration of the fog.

The removal of radioactively contaminated soil is estimated to result in the release of about $1 \times 10^{-9}$ of the inventory of material involved. This assumes releases through high efficiency particulate air (HEPA) filters. This is a relative small source term even when allowing for several orders of magnitude increase related to the uncertainty in the physical description of removal operations. 
The use of open operations for all contaminated soil removal increases the estimated potential release by at least six orders of magnitude. This implies a source term greater than $10^{-3}$ of the inventory involved, which is still small, but approaching the level where detailed analysis to assess dose commitments will be necessary.

\section{TERRESTRIAL ECOLOGY}

The Ben Franklin Dam will inundate about 11,500 acres of riparian lands and 15 islands and create about 16,000 acres of new riparian lands and 40 to 47 new islands of greater area than those inundated. The net effect of these changes on the terrestrial ecology of the Hanford Site cannot be assessed without a detailed study. As a minimum, in the short term the following effects will probably occur:

Columbia River shoreline cobble habitats support plant species not found elsewhere on the Hanford Site and these will be destroyed. Since these species are not reported in the U.S. 'Corps of Army Engineers "Inventory of Riparian Habitats and Associated Wildlife Along Columbia and Snake Rivers" (1976), an investigation should be made to describe and document the plant species.

Construction of Ben Franklin Dam and its impoundment will likely hasten the die-off of trees used as a nest site for the only colony of great blue herons along the Columbia River between McNary Dam and Priest Rapids Dam. The use of the colony as an indicator of food chain contamination may be lost to DOE.

The Ben Franklin Dam will probably be deleterious to the wintering eagle population on the Hanford Site. Bald eagles are regarded as "threatened" in the state of Washington. Bald eagle populations that winter on the Hanford Site are apparently attracted to the food supply provided by Columbia River salmon and wintering concentrations of migratory waterfowl. In recent years, wintering eagles have increased in numbers.

Construction of Ben Franklin Dam and impoundments will expose the Hanford mule deer to increased predation by coyotes due to alteration of islands and tree-shrub fawning habitat. 
Astragalus columbianus, a species of vetch indigenous to the Columbia Basin and officially listed as endangered and thought to be "extinct" was "rediscovered" near Priest Rapids Dam in the spring of 1978. Preliminary investigations indicate that $A$. columbianus occurs as small isolated populations. Definitive information on the abundance of geographic distribution of A. columbianus is lacking. Such information is needed to fully assess the impact of the Ben Franklin Dam and impoundment on the population of A. columbianus.

\section{AQUATIC ECOLOGY}

The proposed Ben Franklin Dam would inundate a unique and productive area of the Columbia River, the last remaining free-flowing (unimpounded) stretch of river (above Bonneville Dam), which provides critical habitat for a number of important aquatic species which are a valued resource. Continued production of several species of valued fishes would be endangered if the free-flowing section is inundated by the Ben Franklin Dam impoundment. Adult Chinook salmon and steelhead trout spawn in the area that would be flooded. The vulnerable white sturgeon is present and is believed to require a pristine, flowing river for successful reproduction. Smallmouth bass spawn in backwater areas and sloughs which also provide nursery areas for fry of many species. Mountain whitefish spawn in and migrate through the area. Coho and sockeye salmon also migrate past the proposed dam site to spawn above it. The sandroller, an unusual species of limited abundance, also exists in the Hanford Reach.

Creation of an impoundment would favor production of spiny-rayed and rough fish, further altering the composition of fish fauna. The species composition and productivity of organisms at lower trophic levels would also be altered, resulting in an impact on the food base for production of desired species. Slower currents and siltation of the existing well-scoured riverbed will represent a significant habitat modification. As a result the present riverine aquatic community will be replaced by a more lacustrine one. The diverse crayfish and aquatic insect populations, which characterize the existing benthic community and support a variety of game fish stocks, will be altered in favor of forage species less desirable for game fish production. 


\section{SOCIOECONOMIC EFFECTS}

The temporary construction work force required to construct a Ben Franklin Dam would probably rot exceed that required for a single nuclear plant. The 1500 to 2000 worker peak might last longer than that for a nuclear plant, and the construction period would be about 7 years. The socioeconomic effects resulting from the construction work force would not be as large as those presently sustained from construction of WNP 1, 2, and 4. However, the absolute impact would depend on other construction or growth activities occurring at the same time.

Construction of recreational facilities upstream of the dam and upstream of Vernita on the Benton County side will probably increase public interaction with other parts of the Hanford Site.

\section{ONGOING DOE R\&D PROGRAMS}

The effects of Ben Franklin Dam on short-term DOE-sponsored R\&D programs is expected to be minimal because the reservoir would not be filled until about 1995. However, long-term monitoring-type programs in both terrestrial and aquatic ecology areas would be disrupted by the dam. 


\section{RECOMMENDATIONS}

The major recommendations from this study include:

1. A combined hydrogeologic and soil characterization study of the Wahluke Slope area of the Hanford Site is required to assess the stability of the 1 and mass under both present and earthquake conditions, as well as the likely consequence to earth slides. The objectives of the study would be (a) to define steps which could be taken to reduce the current high probability of a massive slide from the Wahluke Slope area into the Columbia River, and (b) to estimate the incremental effect of a Ben Franklin Dam on the Wahluke Slope area. Some initial tests and analyses would permit the study to be more accurately defined. The recommended study is estimated to cost about $\$ 350,000^{\star}$ and is comprised of subtasks $1 c, 2 \mathrm{a}$, and $4 \mathrm{a}$ in Table 1 .

2. The extent and timing of decommissioning activities in the 100 Areas required by the building of Ben Franklin Dam depend on a number of factors which could not be fully assessed in this study, including:

a. The relative economics of decommissioning activities under present or post-Ben Franklin Dam (flooded) conditions.

b. The radioactive material release rates from retention basin systems and liquid and solid waste disposal facilities in the 100 Areas affected (or potentially affected) by the proposed reservoir.

It is believed that pre-Ben Franklin Dam decommissioning of $100-\mathrm{F}$ and $\mathrm{H}$ structures and radioactive waste sites is a prudent action based on several factors, including projected DOE plans for decommissioning surplus facilities; greater ease of decommissioning under non-flooded conditions; proper control of radioactive materials in existing facilities and in burial grounds; greater potential for public interaction with the Hanford Site due to the reservoir

* The cost estimates presented in this report are conceptual stage cost estimates, and have a probable accuracy of about \pm 25 percent. The range of accuracy of cost estimates in Recommendation 2 may be even greater because (a) dismantling major facilities like the 105 Buildings has never been done, (b) the release criteria for disposal site decommissioning has not been established so that actual operational requirements can be scoped, and (c) the extent of soil removal with very low level of contamination remains to be established. All estimates are in present dollars. 
location and projected recreation areas; and the potential for a massive earth slide across the river from $100-\mathrm{F}$ and $100-\mathrm{H}$ Areas, and the resulting potential complications.

The estimated total decomissioning cost was calculated to be $\$ 166,000,000$; actual costs will probably be in the range of $\$ 100,000,000$ to $\$ 250,000,000$. Major components of the cost include dismantling the reactors and ancillary structures in the $100-\mathrm{F}$ and $100-\mathrm{H}$ Areas, estimated at about $\$ 43,000,000$; removing liquid and solid waste disposal sites in the $100-F$ and $100-H$ Areas, estimated at about $\$ 62,000,000 *$; and dismantling portions of the reactor effluent discharge systems and associated contaminated soils at the $100-\mathrm{F}, 100-\mathrm{H}, 100-\mathrm{D}, 100-\mathrm{K}$, and 100-B Areas, estimated at about $\$ 28,000,000$. (An alternative to the latter item is to fix contamination in place by filling the lines with concrete or grout. Pockets of contaminated material under them would also be removed or fixed in place.) Other costs are presented in Table 26.

Because there are major uncertainties in the cost estimates pertaining to waste disposal site and contaminated soil removal, it is recommended that the release potential and release criteria** be established for all 100 Area retention basin systems and liquid and solid waste disposal facilities potentially affected by the proposed reservoir. The estimated cost of developing this information is $\$ 850,000$. Performing these studies will establish which facilities need to be removed and which can be left in place or protected by alternative means.

Should the $100-F$ and $H$ structures not be dismantled by the time the reservoir is filled, then the following actions are recommended:

a. Reexamine soils under the $105-\mathrm{F}$ and $H$ and associated structures in light of the more up-to-date triaxial compression and simple shear tests to evaluate their liquefaction potentials.

b. Monitor the settlement of the reactor buildings in $100-F$ and $H$ Areas.

* This estimate is based on a number of assumptions regarding the extent of contaminated soil and waste materials with these facilities.

$\star \star$ Defined on p. 127. 
TABLE 1. Surmary of Estimated Cost of Task Recommendations (in 1978 Dollars)

Estimated

Cost

Task 1 - Groundwater-Hydrology Analys is

a. Improve accuracy of groundwater model $1 \quad \$ 25,000$

b. Establish radioactive contaminant transport times to $r$ iver

(included in Task 5B)

c. Perform groundwater flow analysis of left bank area of Hanford Site

125,000

Task 2 - Soil Liquefaction Analysis

a. Perform hydrogeologic and soil mechanical analysis of White Bluffs area

50,000

b. Evaluate liquefaction potential of foundation materials under 105 Building structures 240,000-320,000

Task 3 - Hydrostatic Uplift and Soil Effects on Structures

a. Install settlement monitors and fill basins and galleries in 100-F and $H$ Areas (contingent on decommissioning plans)

725,000

b. Removal of contaminated lines in backfill in 100-F and $H$ Areas (contingent on decommissioning plans) 250,000-500,000

c. Study of effects of maximum probable flood 30,000

Task 4 - Assessment of the Potential for Landsliding and Sloughing

a. Evaluate landslide potential along White Bluffs 154,000

Task 5 - Facility Decommissioning

a. Estimated facility decommissioning costs $100,000,000-250,000,000$

b. Decommissioning mode study

c. Decommissioning related studies

d. Install security fencing

850,000

80,000

400,000

Task 6 - Hydrothermal Analysis

a. Hydrothermal investigations of Hanford Reach 50,000-100,000

Task 7 - Meteorological Effects

a. Required studies are included in Task 5b

Terrestrial Ecology Studies

Aquatic Ecology Studies

Socioeconomic Effect Studies

Public Interaction Studies

$\$ 300,000-500,000$

Not estimated

Not estimated

Not estimated 
c. Fill basins, pump wells, and other structures in 100-F and $H$ Areas (and selected structures in other areas) to protect against hydrostatic uplift.

The estimated cost of items (a) through (c) is about $\$ 800,000$.

3. It is recommended that the soils under the 105 structures in the 100-B, 100-K, and 100-D Areas be examined to evaluate their potentials for liquefaction. The estimated cost is $\$ 240,000$.

4. If the building structure decommissioning activities described in Recommendation 2 are not done, it may be necessary to remove contaminated lines through backfill which will become saturated from the higher groundwater level in the 100 Areas. Such lines typically originate at the reactor building and would include, in addition to the cooling water effluent lines, other waste water such as drains from the storage basin overflows, washpad area, and waste lines from other decontamination operations. Primarily, 100-F and 100-H Areas are involved in this recommendation. The estimated cost of this work is about $\$ 250,000-\$ 500,000$.

5. The effect of the Ben Franklin Dam on flood elevations experienced during the probable maximum flood $(1,440,000 \mathrm{cfs})$ was not determined nor were the effects of the flood evaluated. Should it be desirable to evaluate them, the estimated cost for such a study is about $\$ 30,000$.

6. It is recommended that a study be performed to identify the costs and benefits of dam construction versus other power developments which would utilize the heat sink capability of the Columbia River in the Hanford Reach. The hydrothermal investigations conducted as part of this study indicate that because of the limited thermal carrying capacity of the Hanford Reach, large-scale energy development on the order of a nuclear energy center at Hanford would be impacted by the construction of Ben Franklin Dam; this conclusion assumes that once-through cooling is a viable alternative for at least a certain percentage of the HNEC reactors. It is estimated that a study would cost about $\$ 50,000$ to $\$ 100,000$. 
7. It is recommended a comparison be made between the terrestrial ecology heritage that presently exists with that which is likely to accrue to Hanford as a result of the creation of new riparian lands and is lands. The required study is estimated to cost $\$ 100,000$ per year for 3-5 years.

8. Because construction of the proposed reservoir may facilitate public use of the Hanford reaches of the Columbia River, facilities having attractive nuisance potential should be removed or isolated. It is recommended that potentially hazardous facilities within approximately one mile of the shoreline, not recommended for removal and not currently enclosed by security fencing, be enclosed by industrial-quality security fencing. The cost of this work is estimated to be $\$ 400,000$.

More detailed recommendations follow each Task writeup. 


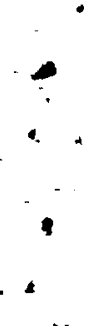

$\therefore$

$\because$ 


\section{INTRODUCTION TO TASK STUDIES}

The Ben Franklin Dam study consists of seven tasks, as previously stated. Some comments are also provided in the areas of terrestrial and aquatic ecology, socioeconomic effects, and public interactions with the Hanford Site.

Each task is described according to the following format:

- Statement of the Problem

- Scope of Investigation(s)

- Significant Findings

- Recommendations

- Cost Estimate (where appropriate)

For some tasks, it was not practical to develop cost estimates for corrective action to accommodate the Ben Franklin Dam. In those cases the scopes of additional studies, which would permit estimates to be made, are defined. 


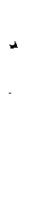

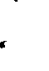

. 


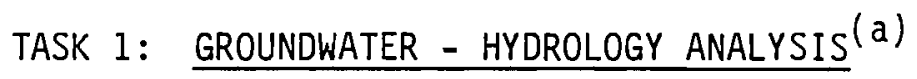

\section{PROBLEM STATEMENT}

The Columbia River serves as base level for the Hanford Site unconfined groundwater system. Water in transit through the system, including waste water disposed to ground reaching the water table, eventually discharges to the river. The water level of the river has a profound effect on groundwater levels, streamlines/flow paths and velocities (particularly adjacent to the river).

Construction of Ben Franklin Dam with a pool elevation of 400 feet MSL will result in an increase in river level of about 50 feet above the present mean stage at the damsite. A comparable rise in the groundwater table will occur near the dam with decreasing effects noted upgradient and upstream from the structure. The increase in groundwater levels may impact buildings, waste disposal facilities and other structures as well as increase the potential for landsliding and sloughing.

This analysis sought to provide a quantitative assessment of expected groundwater levels for the unconfined aquifer on the Hanford Site. These data are then used in Tasks 2, 3, 4, and 5 in the evaluation of soil liquefaction, structural effects, landsliding, and facility decommissioning.

\section{SCOPE OF INVESTIGATIONS}

Response of a complex groundwater system to changes such as caused by Ben Franklin Dam are difficult to predict accurately by classical analytical methods. In the early 1960s recognition of the limitations of analytical techniques prompted development of numerical methods for analyzing the groundwater system on the Hanford Site and evaluation of contaminant transport therein. In addition to other capabilities, this development resulted in a numerical code, Variable Thickness Transient (VTT), that was applied to implement a mathematical model of the Hanford Site groundwater system.

(a) J.R. Raymond and A. E. Reisenauer 
The scope of work under Task 1 was limited (Phase I) to using the existing VIT model for predicting the resultant potentiometric surface of the unconfined groundwater system beneath the Hanford Site based on a Ben Franklin Dam pool of 400 feet MSL.

Formulation of the Variable Thickness Transient Groundwater Code

The following is a brief description of the Variable Thickness Transient (VIT) model used in this study to simulate the flow of an incompressible fluid that saturates a rigid, porous soil matrix.

The hydraulic conductivity $(K)$ is assumed to be isotropic but inhomogeneous. Darcy's law is presumed to govern the flow.

$$
q=-K \underline{\nabla} \phi
$$

where

$$
\begin{aligned}
& \phi=\frac{p}{\gamma}+z \\
& q=\text { flux } \\
& p=\text { pressure } \\
& z=\text { vertical distance } \\
& Y=\text { specific weight, density times acceleration due to gravity }
\end{aligned}
$$

Combining Equation (1) with continuity considerations for incompressible flow leads to

$$
\underline{\nabla} \cdot(K \underline{\nabla} \phi)=0
$$

solutions for which are potentials of the Poisson type. For inhomogeneous, isotropic media with negligible soil and water compressibilities, the above equation becomes

$$
K \underline{\nabla}^{2} \phi+\underline{\nabla} K \cdot \underline{\nabla} \phi=0
$$


The Dupuit, or hydraulic, theory of groundwater flow rests on the assumptions that the free surface has only small inclinations and that the slope of the aquifer bottom is slight, causing the streamlines to be essentially horizontal. The effect of the assumptions is that vertical velocities can be neglected so that the equations of flow can be averaged in the vertical direction. The result of averaging Equation (3) in the vertical direction from the aquifer bottom, $h^{0}$, to the free surface is

$$
\underline{\nabla} \cdot\left[K\left(h-h^{0}\right) \underline{\nabla h}\right]=S \quad \frac{\partial h}{\partial t} Q
$$

where $Q>0$ is a source or sink term, the potential head $\phi(x, y, z, t)$ is replaced by the elevation of the free surface, $h(x, y, t)$, and $\underline{\nabla}$ is the two-dimensional $(x, y)$ gradient operator.

The above equation is known as the Boussinesq (1904) equation of unsteady flow. The number of spatial dimensions has been reduced from three to two and all of the aquifer properties are represented by their average over the saturated thickness of the aquifer. The nonlinear free-surface boundary condition makes the differential equation nonlinear but the unknown surface configuration is identical to the unknown dependent variable. The free surface boundary condition with accretion is also incorporated into the differential equation. Surfaces of seepage must be neglected to carry out the averaging in the vertical direction.

\section{The Computer Model}

The computer model based on the above assumptions and equation, described in detail by K. L. Kipp et al. (1972) is similar to the model described by Pinder and Brederhoft (1968). The model provides a means of applying a specific set of boundary conditions to the above equations to produce a transient simulation.

The simulation model for the Hanford groundwater regime uses data on a square grid pattern, each square being 2000 feet on a side. The Columbia River bounds the region on the north and east. The western and southern sides are bounded irregularly by the Umtanum, Yakima, and Rattlesnake ridges and are 
broken by two alluvial valleys and the Yakima River in the southernmost part. Water entering the region from the valley alluvium is accounted for in the model as a flux across the boundary which is sufficient to maintain the proper water table elevation.

The hydraulic conductivity is assumed to be heterogeneous. Its spatial distribution was determined from pump test data. These data are used in a computer routine which makes it possible to extend the distribution to areas away from the pumped wells. The aquifer bottom, necessary input to the model, is generally considered to be the top of the basalt or the top of the Ringold clay where it overlies the uppermost basalt flow.

\section{The Simulation}

The groundwater system at Hanford has been in a continuous state of change, mainly due to the disposal of large volumes of cooling waters on the Hanford Site. These cooling waters were disposed of in varying volumes in the 200 and 100 Areas. With the closure of all but one of the plutonium production reactors, disposal has been stopped in all the 100 Areas except 100-N. The disposal volume for the 200 Areas was chosen to be an average year without the volume disposed from waste evaporators.

As a base for the simulation the new river boundary for the 400 foot pool was determined from the USGS topography map. The elevation of the new pool was determined from the backwater curve versus river mile graph provided by the Corps of Engineers for the 300,000 cfs flood condition. This condition was simulated because it would produce a "worst case" situation for the Hanford Site.

The vertically average hydraulic conductivity of the presently saturated aquifer was assumed to be also representative of the sediments that would be saturated by the elevation of the water table resulting from construction of Ben Franklin Dam.

Figure 3 shows the new water table elevations resulting from the simulation of the Ben Franklin Dam 400-foot pool with a 300,000 cfs flood condition backwater curve. Both the old and new river boundaries are included. 


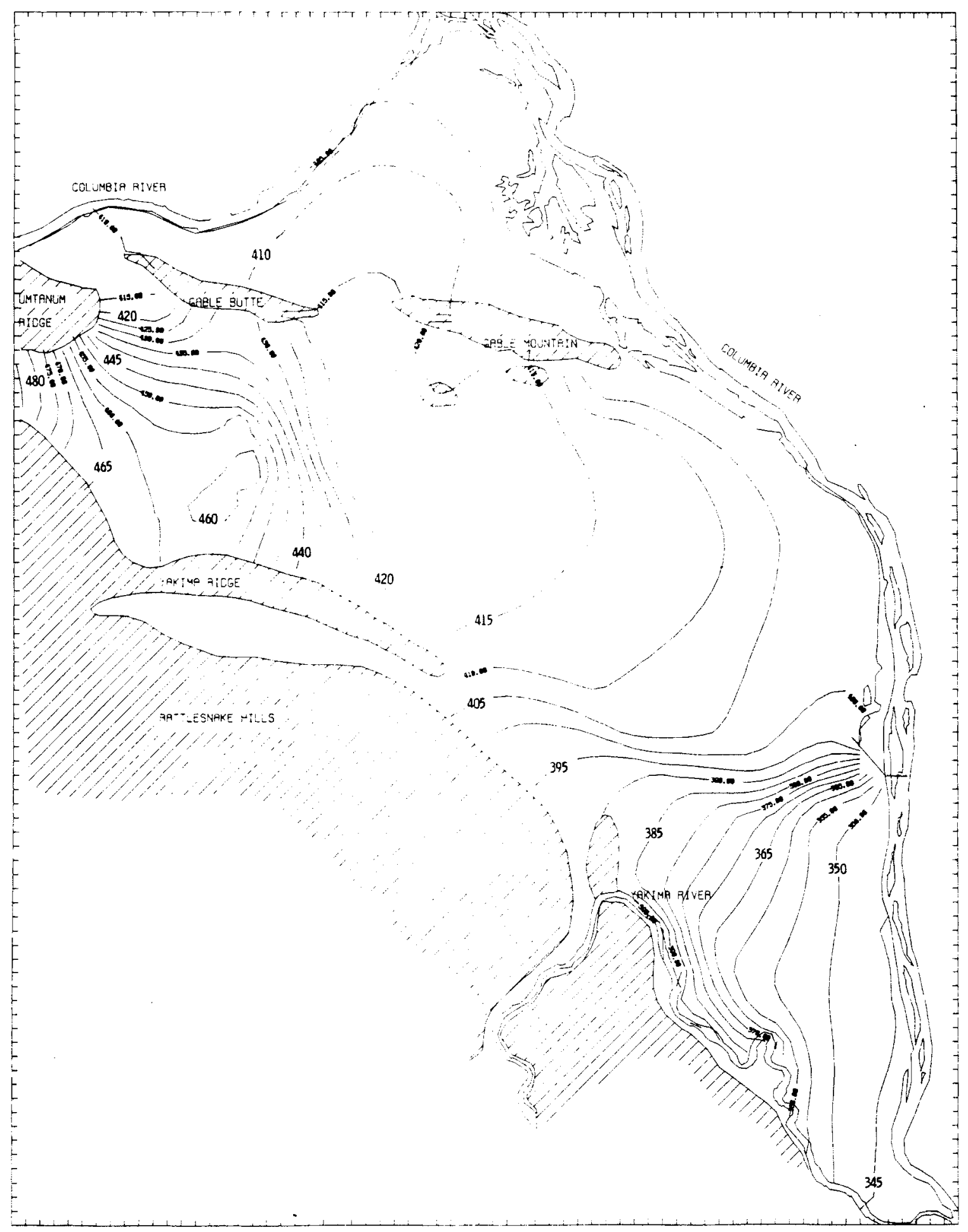

FIGURE 3. Predicted Water Table Resulting from Ben Frank1in Dam 400-Foot Pool 
A subtraction of the digitized 1975 water table map from the Ben Franklin simulated water table is shown in Figure 4. This difference map is the predicted rise of the water table resulting from the above stated conditions.

Using a telescoping feature of the computer code, a subregion model was run for the 100-N Area to delineate the resulting water table near the 116-N-1 crib, the primary disposal site in the 100-N Area. Figure 11 shows the new water table to be expected beneath 100-N Area, if the present disposal to the 116-N-1 crib continues after the dam is constructed.

\section{SUMMARY OF SIGNIFICANT FINDINGS}

The findings based on the groundwater-hydrology analysis are listed below.

1. The reservoir associated with Ben Franklin Dam will raise the groundwater table throughout the Hanford Site. Increases will be about 50 feet near the damsite, 12 to 35 feet in the 100 Areas, and 8 to 16 feet under the 200 Area plateau.

2. The increase in groundwater table under the 200 Areas is considered insignificant with respect to interactions with radioactive wastes located in those areas.

3. The higher groundwater table will cause interactions with buildings and structures as well as with radioactive material burial sites in the 100-F and H Areas. Generally, the water table in the other 100 Areas will be less than predicted in previous studies because waste water is no longer discharged into the ground. An area-by-area analysis is required to substantiate the actual below ground level conditions. This will require performing leach rate tests on existing samples or, in some cases, drilling two or three shallow wells per disposal site, sampling radioactive contaminants, and evaluating findings with a transport model analysis. 


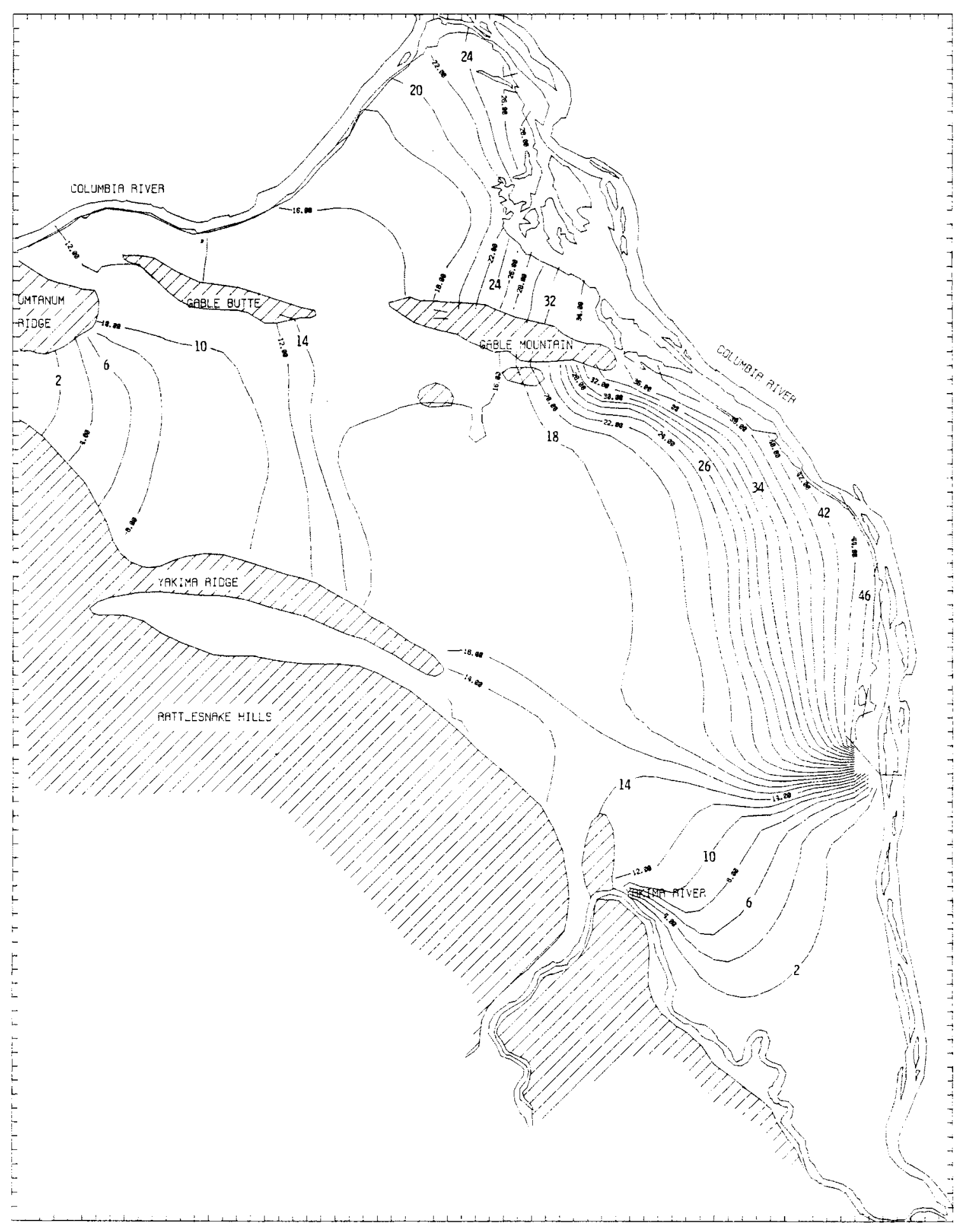

FIGURE 4. Predicted Water Table Rise for Ben Frankl in Dam with 400-Foot Poo 1 
4. The 300 and 400 Areas, the Wye burial ground, and other locations on the right (west) bank of the Columbia River will not be significantly affected by the higher groundwater table caused by Ben Frank 7 in Dam.

5. The Ben Franklin Dam will shorten groundwater flow paths to the river. While resultant travel times will be less, the decrease is not considered significant with respect to transport of radionuclides currently in the water table.

6. The groundwater flow analysis did not include the left bank (Wahluke Slope) area of the Hanford Site, because sufficient data on hydrogeologic conditions do not exist there to develop a meaningful model. Groundwater data from existing wells and an additional estimated five new wells (from which data on physical and chemical characteristics of the soils would also be obtained for hydrogeologic and soil mechanical analysis), together with a modeling/ analytical effort, are needed to evaluate various scenarios of agricultural water use with and without Ben Franklin Dam.

\section{RECOMMENDATIONS}

Three recommendations are based on the groundwater-hydrology analysis.

1. It is recommended that the Hanford groundwater model be upgraded with recent data to improve its precision from \pm 5 feet to \pm 1 foot (over most of the Hanford Site). The improved precision will allow more accurate assessment of groundwater interactions with structures and radioactive wastes. The estimated cost of upgrading the model, including revised groundwater maps, is $\$ 25,000$.

2. It is recommended that several core samples be drilled at the disposal sites considered for decommissioning, but not previously sampled, and radioactive contaminants be identified, and transport times to the river be estimated. The estimated cost is about $\$ 12,000$ per site. About eleven sites require additional sampling. 
3. It is recommended that a groundwater flow analys is be performed for the left bank area of the Hanford Site. This will require (a) data from existing wells, (b) drilling five additional wells for pump testing, (c) establishing the geology, water levels, and physical and chemical characteristics of the soil, (d) analytical work, and (e) model development. With these data it will be possible to evaluate various scenarios of agricultural water use with and without Ben Frank lin Dam. The estimated cost for (a) through (e) is $\$ 125,000$.

\section{REFERENCES}

Kipp, K. L., A. Reisenauer, et al. 1972. Variable Thickness Transient Ground Water Flow Model, Theory and Numerical Implementation. BNWL-1703. Pacific Northwest Laboratory, Richland, WA 99352.

Pinder, G. F., and J. D. Brederhoft. 1968. "Application of Digital Computer for Aquifer Evaluation." Water Resources Research. $\underline{3}$.

\section{BIBLIOGRAPHY}

1. Haney, W. A., ed. 1967. Waste Disposal Facilities Investigations. Part I of The Effects of Ben Franklin Dam on Hanford. BNWL-412, Pacific Nor thwest Laboratory, Richland, WA 99352.

2. Haney, W. A., ed. 1967. Ground Water Flow System Analysis. Part II of The Effects of Ben Frank lin Dam on Hanford. BNWL-412, Pacific Northwest Laboratory, Richland, WA 99352. 


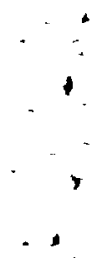

. 


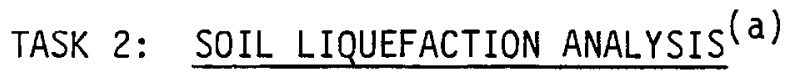

\section{PROBLEM STATEMENT}

Potential for soil liquefaction increases with groundwater level. The Ben Franklin Dam will raise groundwater levels at Hanford along both sides of the Columbia River upstream from the dam to the reservation boundary. How the increased potential for soil liquefaction would influence existing structures and operation modes or future structures and siting options was unknown and required investigation.

\section{SCOPE OF INVESTIGATION}

The Shannon and Wilson subsurface soil investigation (1974) performed for WPPSS is apparently the most definitive Hanford Site study available. Consequently, it is cited in this report to show the conclusions and their bases. In addition, this study included review of four other aspects of the soil liquefaction problem at Hanford:

- field observations along the left bank of the Columbia River in the White Bluffs area to determine the likelihood of liquefaction-induced landsliding with concomitant river channel blockage and existing site damage

- review of reports on other soil investigations at Hanford to evaluate the prospect of soil liquefaction

- review of soil mechanics literature pertaining to soil liquefaction to learn how changes of groundwater level affect liquefaction and to learn whether analytic techniques might alter conclusions drawn from previous investigations of Hanford soils

- review changes of groundwater level resulting from Ben Franklin Dam to determine which sites and structures might be affected by liquefaction. As part of the study of these four aspects of the liquefaction problem, contacts were made with ATan Hosler of WPPSS, and with J. R. Raymond,

(a) M. D. Campbe 11 
J. A. Stottlemyre, C. H. Henager, Sr., R. E. Brown, and Wallace Walters of PNL to clarify certain aspects of liquefaction, earthquake potential, and soil problems. Particularly important to this study were comments by Alan Hosler about expected upper limits of earthquake magnitude and soil liquefaction probability at WPPSS sites 1,2 , and 4 , and a field survey with R. E. Brown and Wallace Walters along the White Bluffs area.

Finally, an effort was made to estimate additional information needed to answer remaining questions about soil liquefaction potential at Hanford and how much it would cost.

\section{Engineering Considerations in Soil Liquefaction at Hanford}

The important idea obtained from other reports about soil liquefaction is that under its influence buildings usually move vertically or horizontally until they disintegrate or deform and become structurally unsound. Many examples exist in which severe vertical displacement has resulted from soil liquefaction beneath the structures. Such vertically downward displacement is often associated with appearance of nearby sand boils, visible at the surface, where temporarily confined water beneath the earth-structure mass ultimately found vent. Commonly, vertical movement follows horizontal movement in which an overlying soil mass rides laterally over its underlying counterpart on a thin layer of water that is confined there during the transport interval and then drops into voids under the influence of gravity. Examples of these two types of movement attended the Niagata and Alaskan earthquakes of 1964 . In both cases, earthquakes caused the lateral shearing forces that resulted in liquefaction of the soils. Settling and sand boils were evident at Niagata, while massive landsliding under the force of gravity attended the Alaskan liquefaction. In both cases, the damage was out of all proportion to the magnitudes of the earthquakes. The unusually great damage was the consequence of subsurface soil liquefaction. With this brief review of what soil liquefaction can do, it will now be profitable to examine what soil liquefaction is and how likely it is at Hanford.

The soil does not actually become a liquid. Instead, when soil pores are full of water and stress is applied, if the water is confined within the initial soil matrix while the bulk density of the solid phase within that 
matrix increases, then sufficient lateral stress at a shearing plane will cause formation of a thin film of buoyant water on which the overburden will move with relatively little resistance until the pore water pressure drops to a point at which kinetic friction overcomes applied lateral force, whereupon liquefaction ceases.

Application of this principle to Hanford soils dictates removal and recompaction of 10 density soil materials at construction sites to avoid increases in bulk density. Thus if soil density is sufficiently high, liquefaction does not normally occur. Because care was taken to ensure relative densities above 0.75 under recently constructed major Hanford structures and because such densities require relatively large shearing stresses to produce soil liquefaction, the major engineering considerations of concern in this study raise the following questions: 1) How large are expected earthquake stresses? 2) How dense is underlying soil material? 3) Will soil liquefaction be likely? And then, in order to obtain this information, 4) What soil tests have been made? 5) What conclusions were drawn from the soil tests? and 6) Are these conclusions still valid, based on recent soil testing techniques?

A review of soil mechanics literature revealed that soil conditions and stress loading conditions were important factors in estimating the potential for soil liquefaction. These two factors will now be discussed and applied to Hanford soils. Then, a model for soil shear stress will be shown along with two simple methods for estimating soil liquefaction potential of Hanford soils so that the investigative reports may be evaluated to see whether conclusions drawn in them should be altered.

A definition of soil liquefaction indicates that the soil will continue to deform at low stress, with no resistance, due to high water pressure within the soil pores. Thus, water pressure coupled with other soil conditions predispose soil to liquefaction.

Soil Conditions

Type or texture of soil plays an important role in soil liquefaction. Clay, which is cohesive, is far less susceptible to liquefaction than sand which is normally cohesionless. Fine, cohesionless sand appears to have the 
greatest liquefaction potential, grading off in both coarser and finer soils with little or no evidence of liquefaction in plastic, cohesive clay (Lambe and Whitman 1969; Peck, Hanson and Thornburn 1953; Seed 1968) except under quick conditions. Certain Hanford soils are in the liquefaction susceptibility range.

As previously stated, soil compaction affects soil liquefaction potential. The deeper the zone of potential soil liquefaction, the greater its compression load and the less its tendency to liquefy. Similarly, the more densely packed, the less its tendency to liquefy (Seed 1968). Soil liquefaction potential tends to become negligible at soil depths greater than 50 feet. For these reasons, many soils have been excavated and recompacted under Hanford structures.

Sand layers with other finer texture soil layers interbedded dispose the sand to potential liquefaction by confining the pore water and allowing its pressure to increase when sufficient shear stress is applied to generate particle reorientation in the sand. Sand lenses further enhance soil liquefaction. Such sand layers are evident in the White Bluffs area especially, and possibly in other areas at Hanford as well.

Soil shear strength increases with loading and compaction; maximum compaction depends on a certain moisture content, unique for the specific soil type. After the point of maximum shear strength is reached, additional water reduces the shear strength until, under special confining conditions, sufficient water is present to produce the required pore water pressure for liquefaction when some external force acts to increase soil bulk density. At such pressure, shear strength fails entirely (Seed 1968). If soil lies below the free water surface, its submerged weight is reduced to about half its dry weight and the soil-bearing capacity is similarly halved, settlement of a structure is apt to be doubled (Lambe and Whitman 1969). Structure settlement depends, however, on relative density of the earth material as well as on the water table level. Such settlement without release of pore water pressure leads to soil liquefaction. Under some of the WPPSS structures with shallow foundations and possibly under some of the 100-H and 100-F Area structures, this type of liquefaction may become a problem. 


\section{Stress Loading Conditions}

Onset of soil liquefaction is a function of amplitude, frequency, and duration of shearing stresses when susceptiblity to liquefaction exists. Hanford soils like those at WPPSS sites 1,2 , and 4 would probably liquefy if a maximum probable earthquake for this zone were to occur.

According to Seed and Idriss (1971), maximum shearing stress required for soil liquefaction depends on the soil type, its relative density, the fluid phase confining pressure, and the duration of the stress loading. However, soils capable of withstanding design earthquake amplitudes of $0.25 \mathrm{~g}$ for more than 10 cycles should be regarded as having low liquefaction potential.

If the pore pressure can drop below that required for liquefaction before the necessary number of cycles has transpired, soil liquefaction will not occur. Also, if liquefaction does occur while pore water pressure is dropping rapidly, soil will restabilize as soon as pore pressure has dropped sufficiently. These facts are important for Hanford soils because Hanford soils are generally unconfining down to 50 feet deep and they are generally highly porous and hydraulically conductive.

\section{Estimating Soil Liquefaction Potential (Two Methods)}

One method of predicting the potential for soil to liquefy requires demonstrating that the shear stress from ground movement exceeds the soil shear strength. This method is shown here for reference only but it forms the basis for conclusions of Shannon and Wilson on the WPPSS study. Evaluation of the following equation may be helpful:

$$
\tau_{\mathrm{av}}=0.65 \frac{\lambda \mathrm{h}}{\mathrm{g}} A_{\max } r_{\mathrm{d}}
$$

where

$$
\begin{aligned}
& A_{\max } \text { is maximum ground surface acceleration } \\
& \lambda \text { is the unit weight of the soil } \\
& h \text { is the depth below the ground surface to the unit soil being } \\
& \text { investigated } \\
& g \text { is acceleration due to gravity }
\end{aligned}
$$


$r_{d}$ is an acceleration correction factor obtained from Figure 5 $\tau_{a v}$ is the average shear stress to be calculated.

The 0.65 comes from the observation that

$$
\frac{\tau_{\text {av }}}{\tau_{\max }}=0.65
$$

and $r_{d}$ compensates for the fact that soil is deformable rather than a rigid body. This type of estimation of liquefaction potential depends upon use triaxial compression or simple shear test information. As shown later, such tests were made at $100-\mathrm{N}$ and present WPPSS sites.

If the value of $\tau_{a v}$ is greater than soil shear strength at the site in question, there exists the potential for soil to liquefy. This conclusion holds true for depths ranging down to about 50 feet. Below 50 feet liquefaction becomes unlikely.

Figure 5 is useful for obtaining $r_{d}$ values to be used in the first method, where values of $\lambda, h, g$, and $A_{\max }$ may be measured or estimated.

A second method of predicting the potential of soil to liquefy is based on analysis of data taken by a Standard Penetration Resistance Test conducted at the site in question and then compared with similar historical data from liquefied and nonliquefied soils. The Standard Penetration Resistance Test consists of counting the number of blows per foot required to drive the test pile through the soil in question. If comparison of the data thus obtained clearly indicates either that the soil will or will not liquefy, further testing is usually unnecessary. This test has been made on several Hanford soils and has served as the basis for recompaction recommendations.

Figure 6 presents historic occurrences of liquefaction. It may be helpful in estimating liquefaction potential based on the relative density and historic surface acceleration of a number of quake sites. It can be used as an indicator of the potential if either the relative density or the surface acceleration is known from historical data. 


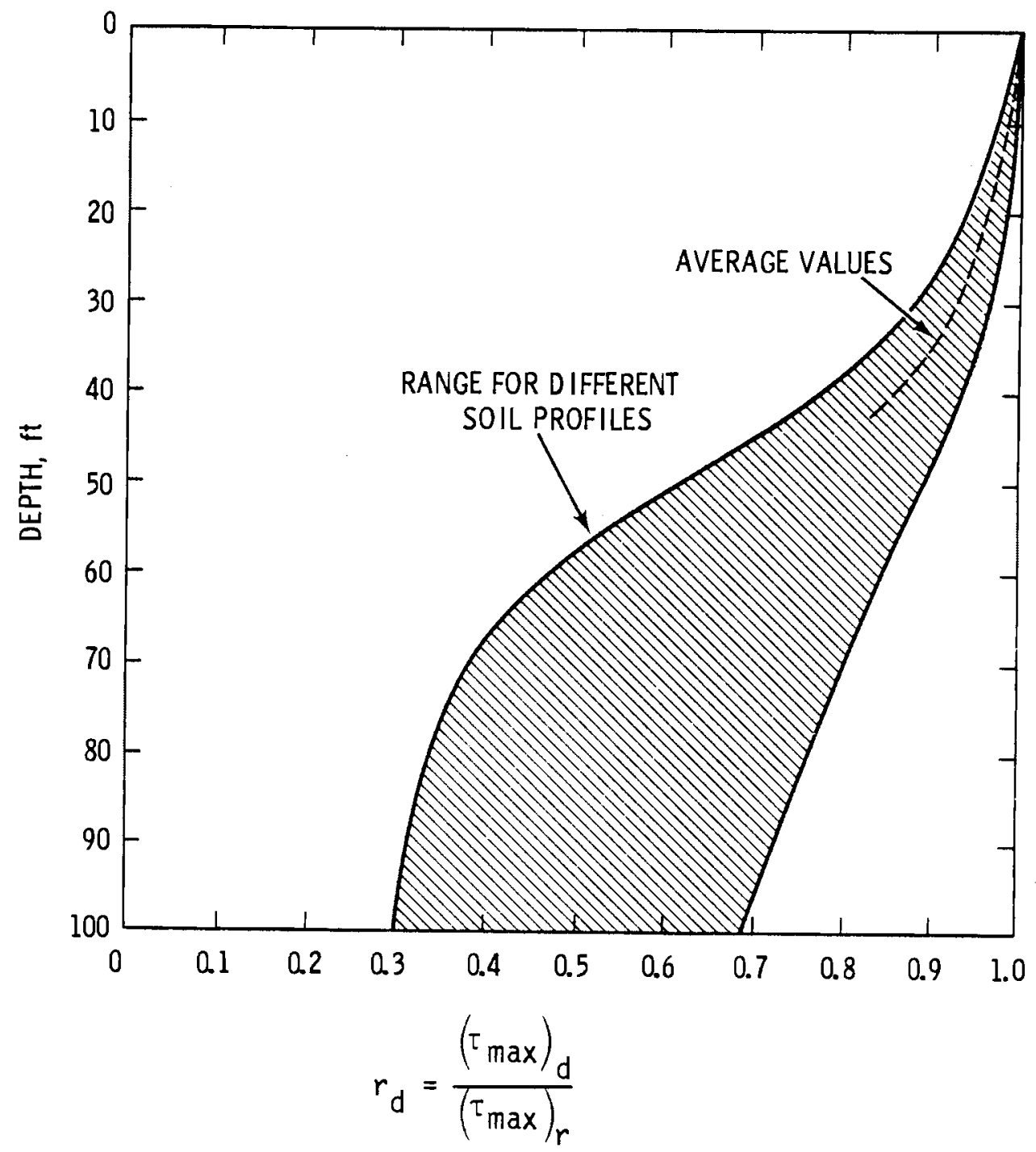

FIGURE 5. Range of Values of $r_{d}$ for Different Soil Profiles (after Seed and Idriss 1971)

\section{Literature Survey}

Five reports were reviewed for this section. Their most pertinent information is contained in the following summaries.

Shannon and Wilson Reports for WPPSS (1973, 1974)

This report is quoted extensively to show the ir conclusions and the basis for them. It represents the most extensive subsurface survey record found. 


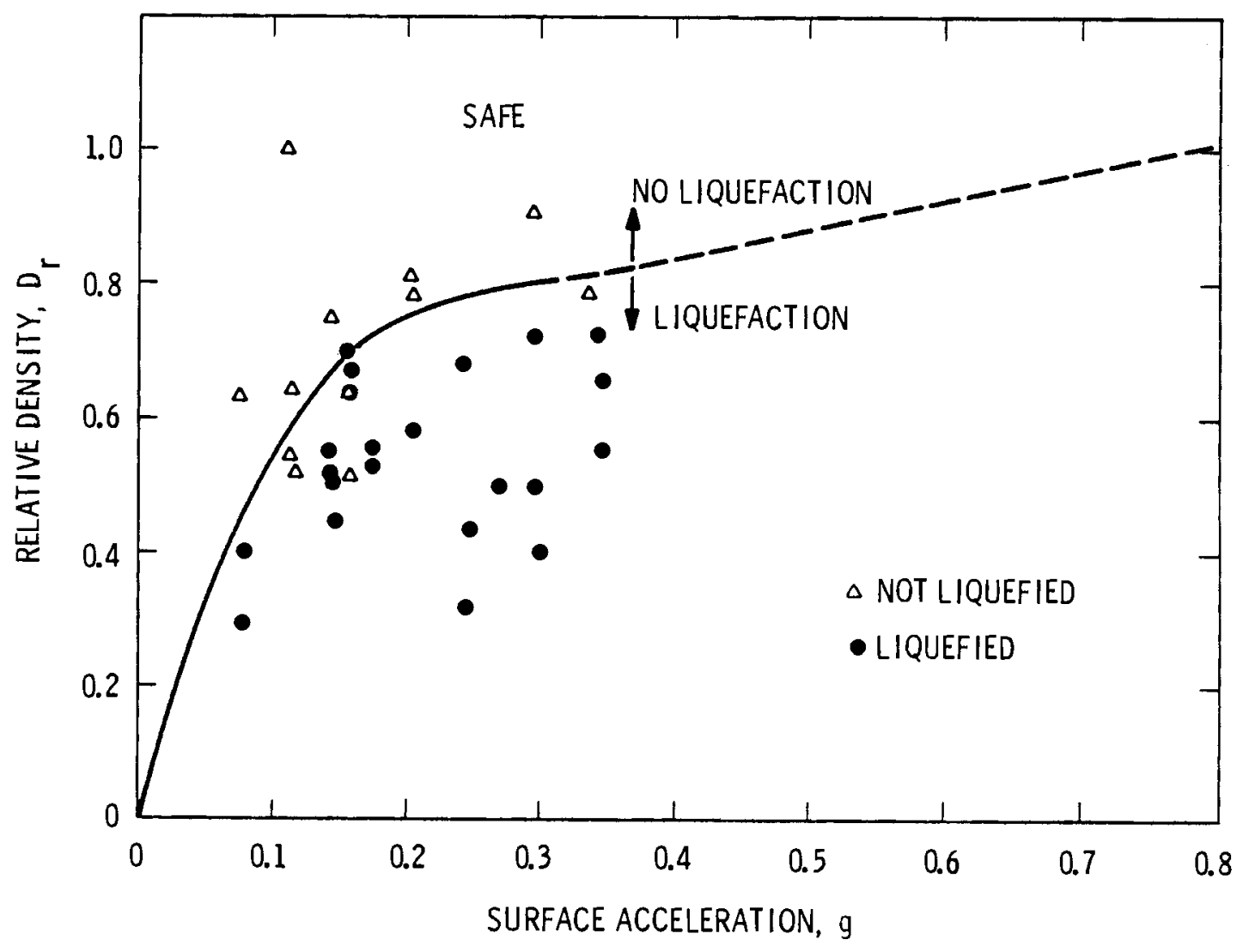

FIGURE 6. Historic Occurrences of Liquefaction (after Ferrittos 1977)

An exerpt from Report of Nuclear Project No. 1, April 1973 (which preceded Amendment 9 and pertained to the area of the $\mathrm{N}$-Reactor) indicates the magnitude of the investigation:

Subsurface explorations were conducted at the proposed WPPSS Nuclear Project No. I site to determine applicable soil parameters for engineering analyses and evaluations for the design of structure foundations, and for planning plant construction.

Explorations consisted of test borings, test pit excavations, refraction seismic surveys and downhole seismic surveys. Fourteen borings, totaling 2,769 feet of drilling, were accomplished in the central plant area. The borings, ranging in depth from 112 feet to 117 feet for a total of 344 feet, were drilled east of the existing substation for possible future structures.

Representative penetration resistance samples and undisturbed thinwall samples were retrieved from the borings for laboratory testing, to establish basic physical and engineering properties of the site soils. 
Two seismic refraction velocity traverses $(3,900$ feet and 4,000 feet long) were conducted in the central plant area, crossing at the Containment Structure location, to assist in delineation of the high velocity refracting surface. A third refraction velocity traverse, 6,000 feet long, was conducted on the north side of the Columbia River across from the central plant area. Two 1,000-foot long reconnaissance traverses were also completed north of the river, to develop information for planning shot holes and detector spacing prior to conducting the three main refraction velocity traverses.

Downhole compressional wave velocity surveys were performed in our selected borings to depths of 70 feet, to provide velocity data for seismic refraction interpretation. Downhole shear-wave velocity surveys, to depths ranging from 140 feet to 390 feet, were performed in three selected borings in the central plant area, to provide additional information for establishing static and dynamic soil property data for design.

From the description it is apparent that this subsurface soil investigation had a substantial data base from which to draw conclusions about existing natural soil conditions. But what about low density soil materials below structures? the report indicates that:

Foundations of the deeply-founded plant structures will be supported in very dense sands and gravels. Foundations of shallower structures will be supported in compacted granular backfill adjacent to the deeply-founded structures.

Due to the granular nature of the foundation soils, resulting settlements will occur rapidly with the application of loads. Post-construction settlements will consist only of that percentage of the maximum total or differential settlements resulting from the application of live loads.

From the soil investigation and substructural recompaction tests, the report concludes that "...the foundation soils are not susceptible to loss of strength, subsidence, or liquefaction resulting from motions associated with the Safe Shutdown Earthquake." (a) This conclusion pertains to the $100-\mathrm{N}$ area and applies to present water levels in the soil. However, the report does consider elevated groundwater level, and states that:

Assuming that the construction of the structural backfill is adequately controlled, this material also has no potential for liquefaction, even under elevated groundwater conditions.

(a) "Safe Shutdown Earthquake" refers to one having accelerations of $0.25 \mathrm{~g}$ for 10 cycles. 
The Shannon and Wilson report to WPPSS in July 1974 (after Amendment 9 which covered soils found at the present WPPSS sites for reactors 1,2 , and 4 ), continues with similar outline of test sequence but notes:

The Category I Spray Pond will also be supported on structural backfill extending to the dense stratum, because of potential liquefaction resulting from a $r$ ise in the groundwater table from future projects in the vicinity.

This shows that removal and recompaction of soils under some structures would be necessary to avoid liquefaction under conditions of elevated groundwater. However, once recompaction is done, the report states that "...soils below approximate elevation 379 feet, and the compacted structural backfills, are not susceptible to loss of strength, subsidence, or liquefaction resulting from motions associated with the "Safe Shutdown Earthquake."

Tests upon which the foregoing conclusions were drawn include the following:

Laboratory tests were performed on representative samples recovered from the borings and test pits to determine the applicable physical and engineering properties of the foundation soils. These tests, in addition to a detailed visual classification of each sample, included water content determinations, Atterberg limits, grain size gradation, unit weight, specific gravity, maximum and minimum density tests, permeability tests, resonant column tests, cyclic triaxial and triaxial compression test to failure, and consolidation tests.

Because different sites are involved, the 1974 report differs from the 1973 report. It states that:

Based on results of the test borings and test pits, WNP-1 and WNP-4 are largely underlain with granular soil which have rock-like characteristics below depths of 60 feet. Both project areas have nearly identical soil conditions and present similar subsurface profiles...

However, the top 60 feet are susceptible to liquefaction as shown by the following corments:

Although the data are scattered, the in situ tests indicate relative densities in a band ranging from about 40-60 percent to an approximate depth of 10-15 feet. Higher values indicated by the SPT, in this depth range, may be due to localized cemented zones, as noted in the test pits.

This would be highly susceptible to liquefaction. 
Below a depth of 15 feet to approximately 60 feet, relative densities fall in a band ranging from approximately 60 to 90 percent at WNP-1. They appear to be approximately 10 percent higher at WNP-4.

Liquefaction potential exists here, too, for relative densities less than 80 percent.

After recompaction of the upper material, backfill material was tested as follows :

Cyclic triaxial tests were also conducted on four reconstituted test specimens of the sand which is to be used as structural replacement backfill at WNP-1 and on three reconstituted test specimens of the sand to be used as structural replacement backfill at WNP-4. These tests were performed to provide support data for the minimum relative density selected for Type A structural replacement backfill to be placed beneath Category I structures so that liquefaction will not occur due to motions associated with the SSE in the event of a future rise in the water table. The test specimens were subjected to cyclic shear stresses comparable to the SSE Loading at one cycle per second for conditions at elevations 415 feet and 405 feet, which correspond to 5 and 15-foot depths below the possible future water table. For these conditions and for cyclic loading of 100 cycles duration, no liquefaction occurred in the specimens tested.

As a general soils engineering evaluation, conditional upon appropriate removal and replacement of backfill material, the report states that:

The subsurface soils present at the WNP-1 and WNP-4 sites are sufficiently competent to provide foundation support for the proposed structures under both static and dynamic loading conditions. A rise in the existing groundwater table to elevation 420 feet (MSL) due to future projects, however, could potentially cause liquefaction in the sand layer that extends from the surface to a depth of about 60 feet, under dynamic motions imposed by the Safe Shutdown Earthquake (SSE). Therefore, the existing sand layer below the spray pond at WNP-1 and WNP-4 will require removal to the underlying very dense gravel, and replacement with compacted backfill. The very dense gravel underlying the sand is not subject to liquefaction regardless of the position of the groundwater table under motions produced by the SSE. The gravel is sufficiently competent to provide direct support for foundations of the Containment and General Services Building.

Tests of most recent origin were used in the analysis without significant change in the conclusions drawn: 
Based on procedures developed by Seed and Idriss (Reference 2P-4), and utilizing a lower bound value for a relative density of 60 percent (based on Gibbs and Holtz correlations with the standard penetration test blow counts Reference 2P-11), the computed factor of safety against potential liquefaction is only slightly greater than 1.0 , when the water table is at elevation 420 feet MSL. Therefore, adequate assurance cannot be provided that the medium dense to very dense sand stratum will not liquefy when subjected to an earthquake equivalent to the SSE used for design. Because of this, all soils above the very dense gravel stratum within the zone of stress influence of Category I structures should be excavated and recompacted to a relative density of 85 percent, which will be approximately double that of the existing site soils $(F . S .=2.0)$.

The underlying very dense gravel and highly consolidated interbedded silt, clay, and sand units below a depth of approximately 60 feet are not susceptible to liquefaction regardless of the position of the groundwater table under motions resulting from the SSE.

Thus, the need for removal and recompaction of certain Hanford soils is evident if soil liquefaction hazard is to be removed. Whether this soil property was considered or adequately covered for 100-Area structures is not known, but it needs to be.

\section{DUN-2349 Final Report I}

The DUN-2349 report (Ba1lowe 1967) states that "...no reservoir conditions would be created from the operation of Ben Franklin Dam at either reservoir elevation which would be adverse to 100-Area facilities and their operations...."

The report further states that:

No significant effect would be expected on facility foundations; however, at $100-\mathrm{F}$ and $-\mathrm{H}$ Areas, where the predicted rise in water table is the greatest, and will extend to, or above, some of the footings, it appears prudent to provide for monitoring settlements in these areas.

In the referenced DUN-2349 report the following statement appears:

Some wind-laid silts and silty sands may suffer a collapse of structure upon inundation. It is not known whether the surficial Hanford aeolian deposits are susceptible to such collapse. The reactor sites are generally dune-free and these soils are shallow. The subgrade for major foundation elements are relatively deep and it is judged that no major foundations are supported on the wind-laid deposits, and that further consideration of these soils is unnecessary. 
There are instances on record involving the liquefaction of saturated loose fine sands during earthquakes. A1though quantitative data on the relative density of sand stringers that may extend beneath structure foundations is not available, the mode of deposition and the relative density of the gravels with which they would be interbedded indicate that these materials would not be subject to seismic liquefaction. For this reason, it is our judgment that this mechanism does not require further investigation.

This conclusion is not based on soil tests, however, and testing of the substructure soils or removal of those structures would seem advisable, especially since monitoring of structural settlement is recommended because of uncertainty.

DUN-1410 Report

The DUN-1410 report (F. E. Jones 1966) contains numerous maps and data on the Hanford area, including information on foundations at plant sites and earthquake history. Regarding the earthquake history of Hanford, the report affirms that there are "...only scattered earthquake epicenters...."

However, of geologic hazards, the report states that:

Earthquakes of enough intensity to cause severe destruction (This term is not defined.) are unlikely in any one year, but their occurrence within any one century is probable. The reservation is included in Zone 2 of the Seismic Probability Map of the United States (U.S. Coast and Geodetic Survey, 1949). This zone includes areas where there is expected one earthquake of an intensity 7 or above on the Rossi-Forel scale and about 5 of noticeable motion and slight damage during each century.

\section{ERDA 1538 Report}

This report contains recent information on the seismology of the Hanford area. In part it states that:

Eastern Washington is in a region of low to moderate seismicity lying between the western Washington and western Montana zones of considerably greater seismicity. On the basis of the damage that has been experienced since 1840, the U.S. Coast and Geodetic Survey (ESSA) designated eastern Washington as Zone 2 seismic probability, implying the potential for moderate damage from earthquakes. Periodic revisions between 1948 (the date of first issuance of the risk map) and 1969 did not change the potential for eastern Washington, although damage potentials for other parts of the country were upgraded. Currently western Washington and western Montana are in a Zone 3 category, implying the risk of considerable damage. The categories are incorporated in the Un iform Building Code. 
Hanford facilities are exposed to the possibility of earthquake damage from two sources: 1) the active seismic zones of western Washington and 2) closer shocks originating in the seismic zone that includes Walla Walla. However, the underlying sands and gravels in the Hanford Reservation provide excellent protection against damage. As far as can be determined, earthquake intensities greater than four on the Modified Mercalli Scale (MM-IV) have not assuredly occurred in the immediate Hanford area, although intensities as high as MM-V or MM-VI were observed at surrounding towns.

The strongest shock of historic record to occur in western Washington was the 1949 earthquake originating in the Puget Sound channel just off Steilacoom, about 150 miles from Hanford. Intensities from MM-VI to MM-VII were experienced at distances of $150 \mathrm{miles}$. Four shocks in western Washington between 1932 and 1946 had maximum intensities of MM-VII.

\section{Field Observations}

On-site inspection of bluffs along the east side of the Columbia River revealed extensive earth slump, slide, and flow. Waste water from irrigation above the bluffs was seeping from a permeable layer midway down the bluffs. Sand is interbedded between finer texture materials, providing a water path through which water moving from the waste ponds above the bluffs could be confined under earthquake stress loading to cause liquefaction. Earth material above this seep face breaks away in slumps and slides. One substantial flow slide is currently in progress just east of the south end of Locke Island. The magnitude of this slide is no doubt sufficient to block the east channel of the Columbia River if it were to occur rapidly. Earthquake type acceleration has the potential to release this slide, which is now occurring slowly but visibly. Soil liquefaction in the bluff areas appears to have significant damage potential to areas directly across the river from them if released by an earthquake in large masses. Probability is especially high during years of above-average precipitation.

\section{SUMMARY OF SIGNIFICANT FINDINGS}

The soil liquefaction analysis resulted in four main findings:

1. Soil liquefaction is not probable in substructure soils at Hanford unless relative soil densities are less than 80 percent or earthquake accelerations exceed $0.25 \mathrm{~g}$ for more than 10 cycles with the Ben Franklin Reservoir at 400 feet above MSL. 
2. Liquefaction does not normally occur below about 50 to 60 feet due to overburden pressure, irrespective of the location of the water table. Thus, the 200 and 400 Areas are not subject to liquefaction because of the depth of the water table. The 100 Areas are subject to liquefaction as previously discussed. Future structures will need to consider the liquefaction constraint in selecting sites. Site locations without liquefaction constraints will be 'more limited with the Ben Franklin Dam.

3. Current tools and techniques used in soil mechanics do not significantly alter conclusions drawn from previous studies, except with respect to the White Bluffs area.

4. The White Bluffs area currently has a very high probability of soil liquefaction, even with minor earthquake acceleration. The Ben Franklin Reservoir and resulting water table rise will increase that probability. The extent of possible slides from liquefaction is discussed in Task 4.

\section{RECOMMENDATIONS}

It is recommended that hydrogeologic and soil mechanical analyses of the White Bluffs area be conducted. Particular emphas is should be directed toward analyses of soil liquefaction potential that could lead to river channel blockage and massive flow slide damage to structures along the right bank of the river. Initially, data from the five additional wells described in Task 1 should be analyzed to evaluate the liquefaction problem. The estimated cost of this work is $\$ 50,000$. Based on the results obtained, additional investigations may be required.

It is recommended that soils under the $105-\mathrm{F}$ and $105-\mathrm{H}$ structures and stacks be reexamined, in light of the more up-to-date triaxial compression and simple shear tests to evaluate their liquefaction potentials, if the structures are not removed. Four bore holes per structure (The reactors and stacks are considered as one structure.) are recommended at an estimated cost of $\$ 10,000$ per hole. Structures in other 100 Areas are considered safely founded with respect to liquefaction potential. However, soil tests to verify soil density are recommended at the 105 structures in 100-D, B, and $K$ Areas. The 100-N Area has adequate soil data. 


\section{REFERENCES}

Ballowe, J. W. 1967. Ben Frankl in Dam Study Final Report. DUN-2349, Douglas United Nuclear, Inc., Richland, Washington.

Ferritto, J. M., AND J. B. Forrest. 1977. Determination of Seismically Induced Soil Liquefaction Potential at Proposed Bridge Sites. Vol. 2 of Planning Guide for Evaluation of Liquefaction. Civil Engineering Laboratory, Port Hueneme, California.

Jones, F. O., and R. J. Deacon. 1965. Geology and Tectonic History of the Hanford Area and Its Relation to the Geology and Tectonic History of the State of Washington and the Active Seismic Zones of Western Washington and Western Montana. Consulting Agreement CA-00056, Douglas United Nuclear, Inc., Richland, Washington.

Lambe, T. W., and R. V. Whitman. 1969. Soil Mechanics. John Wiley \& Sons, Inc., New York, New York.

Olmsted, T. L., T. E. Kirkland, H. H. Druebert and A. J. Hendron. 1974. Subsurface Investigation and Foundation Engineering Evaluation. WPPSS, for United Engineers \& Constructors, Inc. Shannon and Wilson reports before and after Amendment 9.

Peck, R. B., W. E. Hanson and T. H. Thornburn. 196.5. "Foundations on Sand." Chapter 14 in Foundation Engineering. John E. Wiley \& Sons, Inc.,

New York, New York.

Seed, H. B. 1968. "Landslides During Earthquakes Due to Soil Liquefaction." Am. Soc. Civ. Eng. Proc. 94 (paper 6110). Jour. Soil Mech. and Found., Div. No. (SM5): 1055-1122.

Seed, H. B. 1968. "Recent Development in Evaluating the Potential for Soil Liquefaction and Foundation Failures During Earthquakes."

Seed, H. B., and I. M. Idriss. 1971. "Simplified Procedure for Evaluating So il Liquefaction Potentia1." Am. Soc. Civ. Eng. Proc., J. Soil Mech. Found. Div. (JSFEAQ). 97(9):1249-1273.

Shannon and Wilson, Inc. 1967. Report on Soil Stabilization Studies Hanford Reactor Sites with Reference to Ben Franklin Dam. Prepared for Douglas United Nuclear, Inc.

United States Energy Research and Development Administration. 1975. Final Environmenta] Statement Waste Management Operations, Hanford Reservation, ERDA 1538, Richland, Washington. 
TASK 3: HYDROSTATIC UPLIFT AND SOIL EFFECTS ON STRUCTURES ${ }^{(a)}$

\section{PROBLEM STATEMENT}

The objective of this task is to evaluate the effects of the Ben Franklin Dam pool on Department of Energy structures at the Hanford Site, identify problem areas that need further study and estimate the costs of corrective action and additional studies needed.

The problem created at the Hanford Site by raising the Columbia River to a pool elevation of 400 feet above MSL at the Ben Franklin Dam with regard to structures is that soil supporting the foundations, particularly for those structures located along the river, may be affected by the impounded water. One obvious and visible effect is that two of the retired reactor facilities (100-F and 100-H Areas) will be partially flooded, along with several miles of Hanford roads. Another not so visible effect is that groundwater levels throughout the Hanford Site will be raised. This can result in several secondary effects which need to be evaluated. These include: 1) possible changes in the bearing capacity of soils beneath structures; 2) possible seismically-induced liquefaction of cohesionless saturated soil under such structures (the liquefaction phenomenon is the subject of a separate task in this report); 3) hydrostatic uplift on structures such as storage basins, retention basins, and buried tanks and pipelines; 4) consolidation of backfi17;5) possible changes in the earthquake response of structures; and 6) leaching or transport of radionuclides from the vicinity of structures where such contamination has been deposited because of leaks, for example, under retention basins and effluent lines. A related effect, leaching or transport of radionuclides from burial grounds, is discussed and evaluated in the Facility Decommissioning section of this report.

\section{SCOPE OF INVESTIGATION}

This investigation was limited to DOE structures on the Hanford Site. The facilities studied included FFTF, 100-N Area reactor and steam plant

(a) C. H. Henager. 
(but excluding the WPPSS electrical generating facilities), 300 Area, 200-E and $200-W$ Areas and the retired reactor facilities of the $100 \mathrm{~B}-\mathrm{C}, 100-\mathrm{K}$, $100-D, 100-H$ and 100-F Areas.

Input information to this task included:

- the results of the groundwater analysis (Task 1)

- the results of the soil liquefaction analysis (Task 2)

- the results of a prior study by Shannon and Wilson (1966), updated by changes in technology and conditions in consultation with Shannon and Wilson

- other prior studies by Douglas United Nuclear (Ballowe 1967) and PNL (Haney 1967; Jaske 1968)

- data from Preliminary and Final Safety Analysis Reports (PSAR and FSAR) for WPPSS reactors (WPPSS 1978)

- data from the PSAR for the reactor site once considered for a WPPSS reactor at 100-N Area (WPPSS 1973).

The Columbia River flow selected to provide river surface elevations for input to the groundwater model was 300,000 cubic feet per second. This figure was arrived at after consulting with the Seattle District Corps of Engineers, and PNL's Water and Land Resources Department. It represents a flow that would occur at least once every 5 to 10 years and be maintained for about a month which is enough time to affect groundwater levels. This amount was also used to estimate groundwater levels of previous studies (Shannon and Wilson 1966; Ballowe 1967). A flow of 570,000 cfs was selected to evaluate effects of a likely flood and wave action on low lying facilities and the river banks. This figure was developed by the North Pacific Division of the Corps of Engineers (1970) as a standard project flood (regulated) for the Mid-Columbia reach. It is considerably less than the 1894 flood of $740,000 \mathrm{cfs}$, the current figure for an unregulated standard project flood. The rationale offered for the smaller figure is that the new dams upriver in the U.S. and in Canada provide improved river flow regulation. The Probable Maximum Flood for Hanford, derived by the Corps of Engineers (1969), is $1,600,000$ cfs unregulated and $1,440,000$ cfs regulated. 
As noted in ERDA-1538, the Probable Maximum Flood (PMF) of 1,440,00 cfs would inundate reactor areas $100-\mathrm{N}, 100-\mathrm{D}, 100-\mathrm{H}$ and $100-\mathrm{F}$. Inasmuch as these areas would be inundated by the PMF whether the Ben Franklin Dam were constructed or not, the concern of this study focused on effects that could be expected under nonflood conditions of 300,000 cfs for continuous effects attributable to the Dam. This task did not attempt to define new flood levels due to presence of the Dam during a probable maximum flood.

This task did not include soil tests, soil borings or site visits.

\section{Flooding}

Two of the reactor areas, $100-\mathrm{F}$ and $100-\mathrm{H}$, would be partially flooded. The extent of flooding varies with the amount of flow. At a river flow of $300,000 \mathrm{cfs}$ (average daily flow is $120,000 \mathrm{cfs}$ at Hanford), the pool level would be essentially 402 feet at 100-F, according to a Corps of Engineers study (1966). Two burial sites would be submerged along with the 151-F electrical substation site, ash disposal site, some roads, the river pumphouse and the effluent outfall structure (see Figure 7). Water would rise and fall through the bottom of the retention basin located at 399.33 feet, as the groundwater level varied with reservoir operation. When the flood level of 570,000 cfs is used ( 405 feet at $100-F$ ) and 3 feet are added for wave action, other structures would become inundated or endangered, including the gas filter building, $115-F$, adjacent to the reactor.

At $100-H$, upstream from $F$ Area, the 300,000 cfs flow level (402.5 feet) would inundate part of Burial Ground No. 1, the outfall structure, and some of the roads including the primary access road (see Figure 8). At 408.5 feet, 570,000 cfs flow plus 3 feet for wave action, the river pumphouse floor (409 feet) would be in danger of inundation. The retention basin bottom slab at 396.5 feet would be infiltrated by the rising and falling water table.

Several miles of main Hanford roads between Hanford and 100-F area would be flooded under the normal flow of 120,000 to $300,000 \mathrm{cfs}$. If the PMF of $1,440,000$ cfs is considered, four areas are inundated--100-N, 100-D, 100-F, and 100-H. The increase in water depth at these areas during a PMF because of the presence of the dam was not determined. 


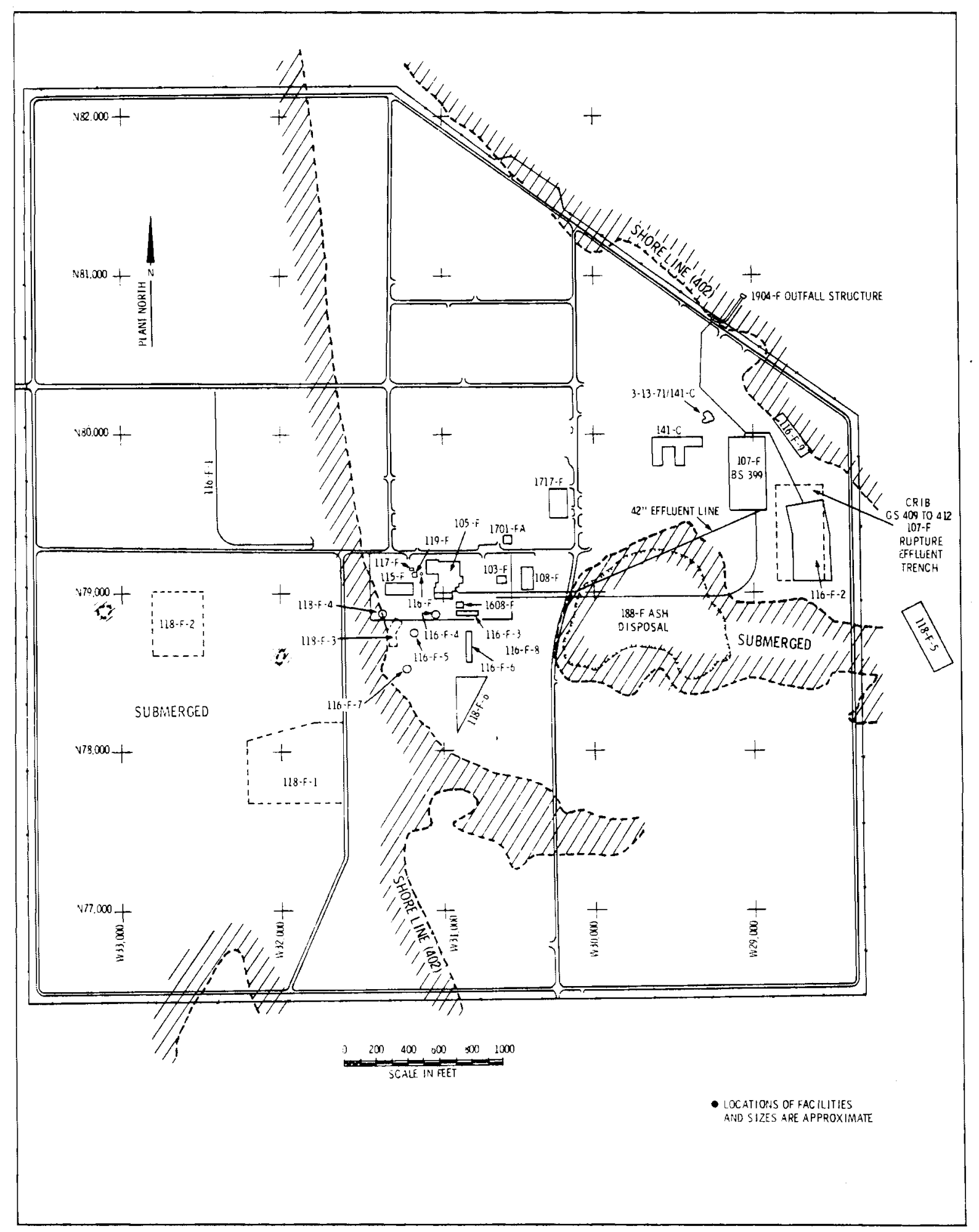

FIGURE 7. Predicted Water Table Contours 400-Foot Ben Franklin Pool Elevation 300,000 cfs $\mathrm{Flow}, 100-\mathrm{F}$ Area 


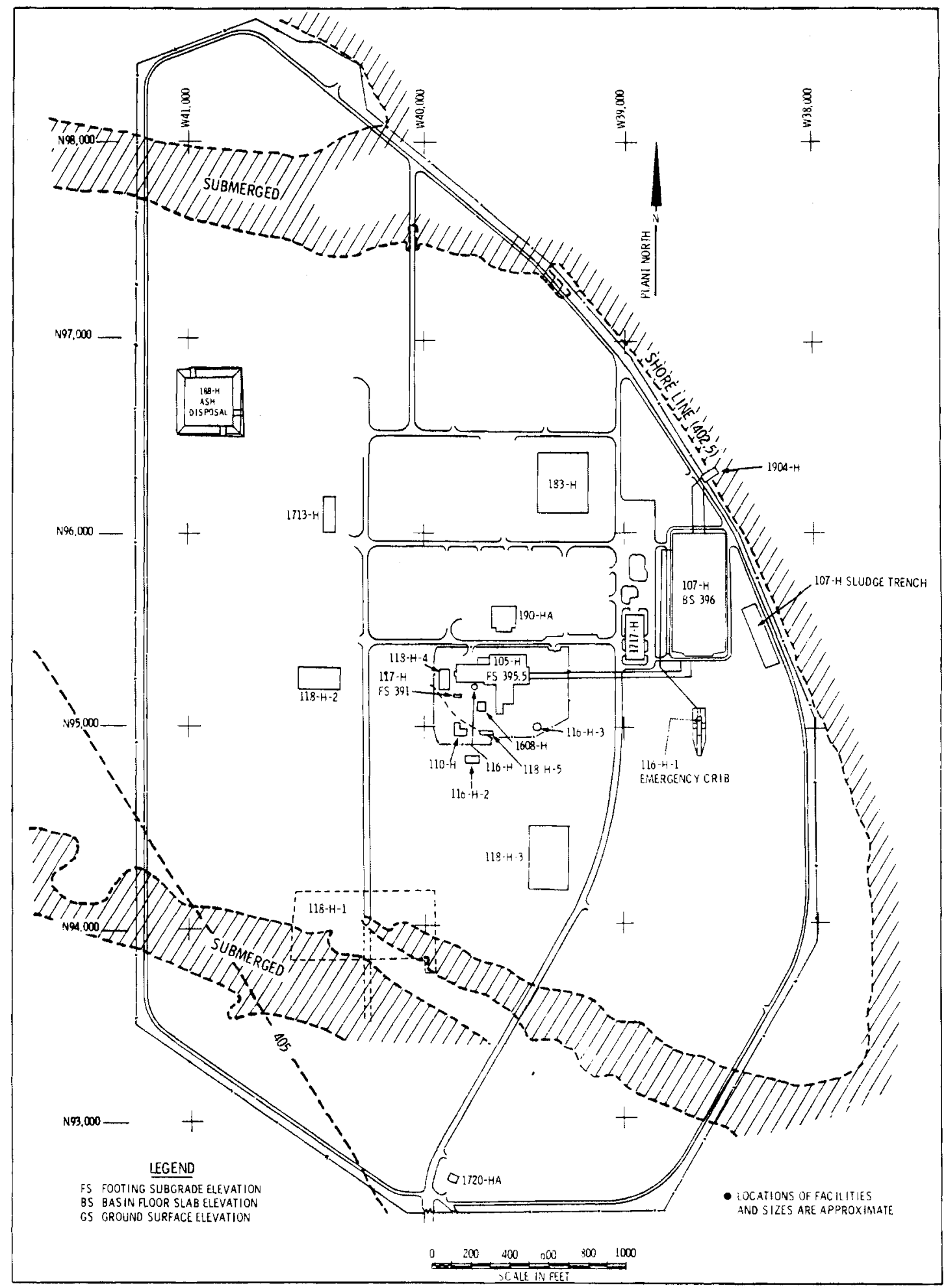

FIGURE 8. Predicted Water Table Contours 400-Foot Ben Frankl in Pool Elevation 300,000 cfs Flow, 100-H Area 


\section{Groundwater Rise}

In the Haney (1967) study, groundwater rises on the order of 16 to 20 feet were predicted for the 100-B, 100-K, 100-N and 100-D Areas. A rise of about 25 feet was predicted for the 200 Areas and the FFTF site. Since that time, several reactors have been shut down and no longer dispose of waste water to the ground via effluent line and retention basin leaks and cribs. Also, the 200 Areas have reduced the amount of waste waters being disposed to the ground. As a consequence, the entire water table at Hanford has subsided significantly and smaller rises in groundwater are predicted as a result of a 400-foot pool. These predicted rises are now on the order of 10 to 16 feet less at the 100-B, K, N and D Areas (see Figures 9 through 12) and about 10 feet less for the 200 Areas and FFTF. Effects on soils, soil properties and foundations can be expected to be somewhat less than the Haney study and fewer structures will be affected or endangered.

Bearing Capacity of Structural Foundations

In the study made in 1966-67, the conclusion reached by Shannon and Wilson and reiterated by Douglas United Nuclear was that no significant effect would be expected on facility foundations from the $400-f o o t$ pool, although it would be prudent to provide for monitoring of settlements in $100-\mathrm{F}$ and $\mathrm{H}$ Areas where the rise in water table extends to and above some of the footings.

The basis for this conclusion is primarily conservatism in the original design, which generally used a maximum allowable value of $8000 \mathrm{lb} / \mathrm{ft}^{2}$ for soil bearing. This figure was backed up by load tests made prior to construction, showing substantially less than tolerable settlements with 1.5 times the design load. Also quoted was the absence of noticeable settlements of foundations on a subgrade of undisturbed material.

Consultation with Shannon and Wilson, Inc., established that the conclusions drawn in their 1966 study regarding bearing capacity of the soils (disregarding liquefaction considerations) are the same today. Those conclusions ended with the statements 


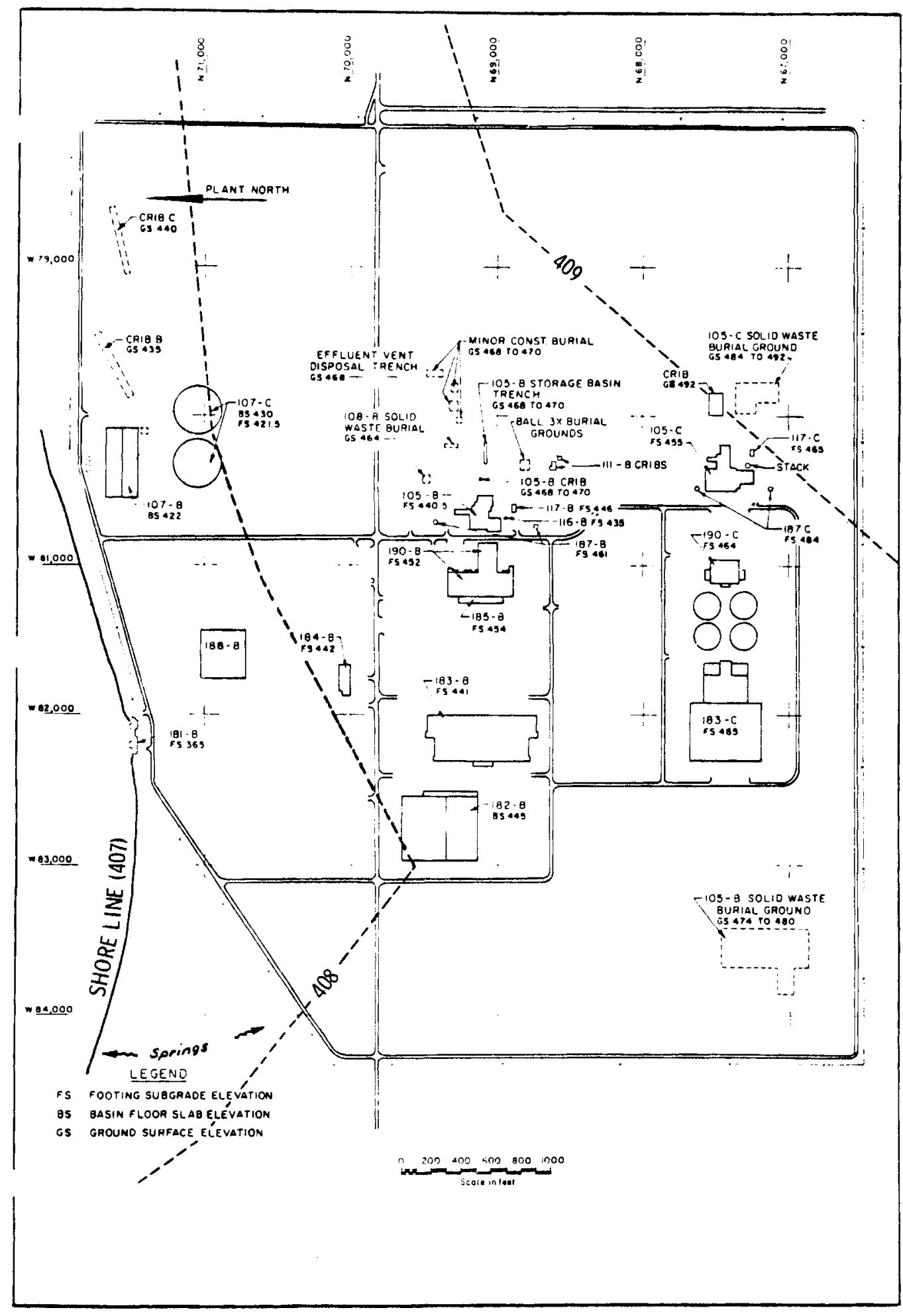

FIGURE 9. Predicted Water Table Contours 400-Foot Ben Franklin Pool Elevation 300,000 cfs Flow, 100-BC Area 


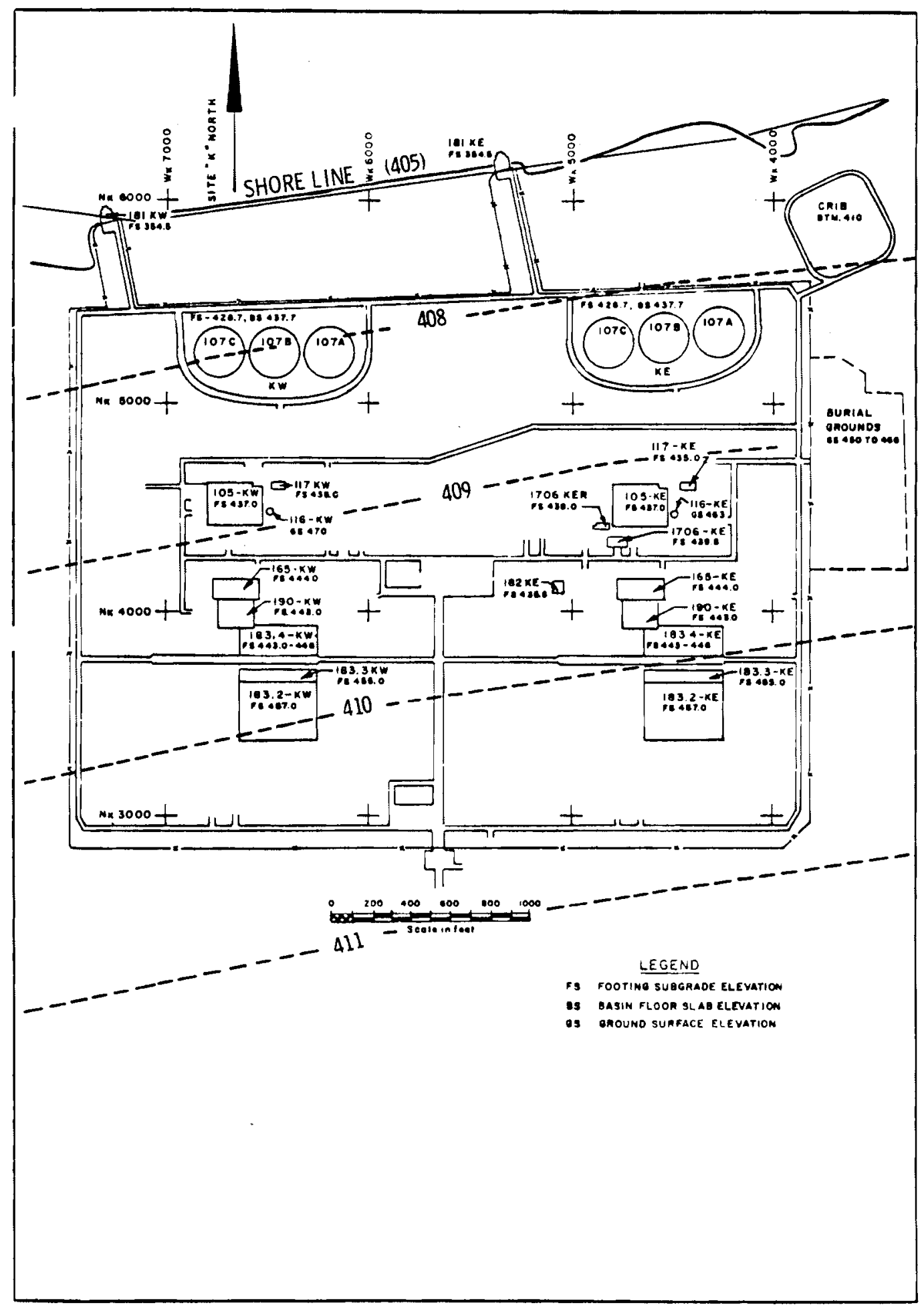

FIGURE 10. Predicted Water Table Contours 400-Foot Ben Franklin Pool Elevation 300,000 cfs Flow, 100-K Area 


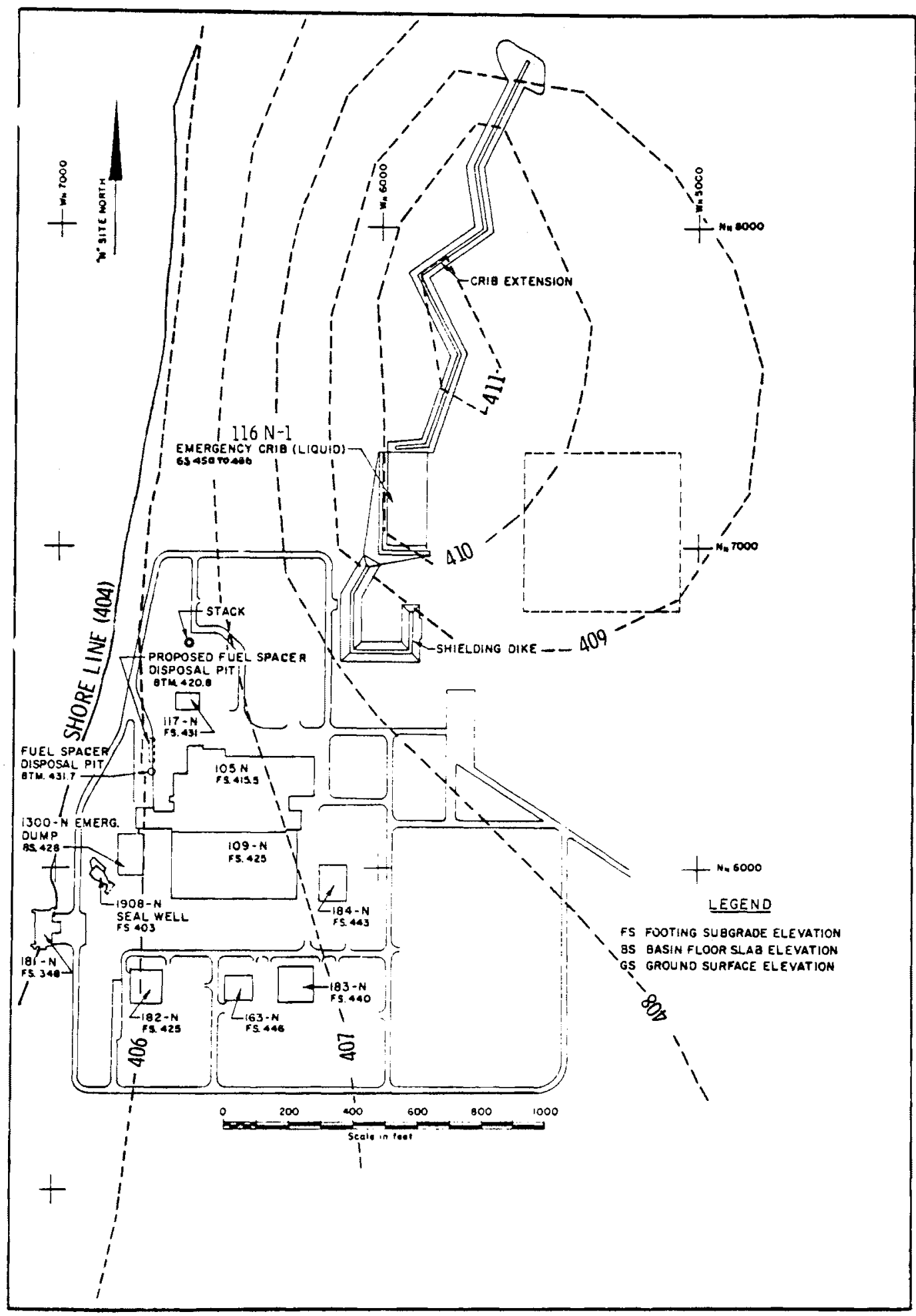

FIGURE 11. Predicted Water Table Contours 400-Foot Ben Franklin Pool Elevation 300,000 cfs Flow, 100-N Area 


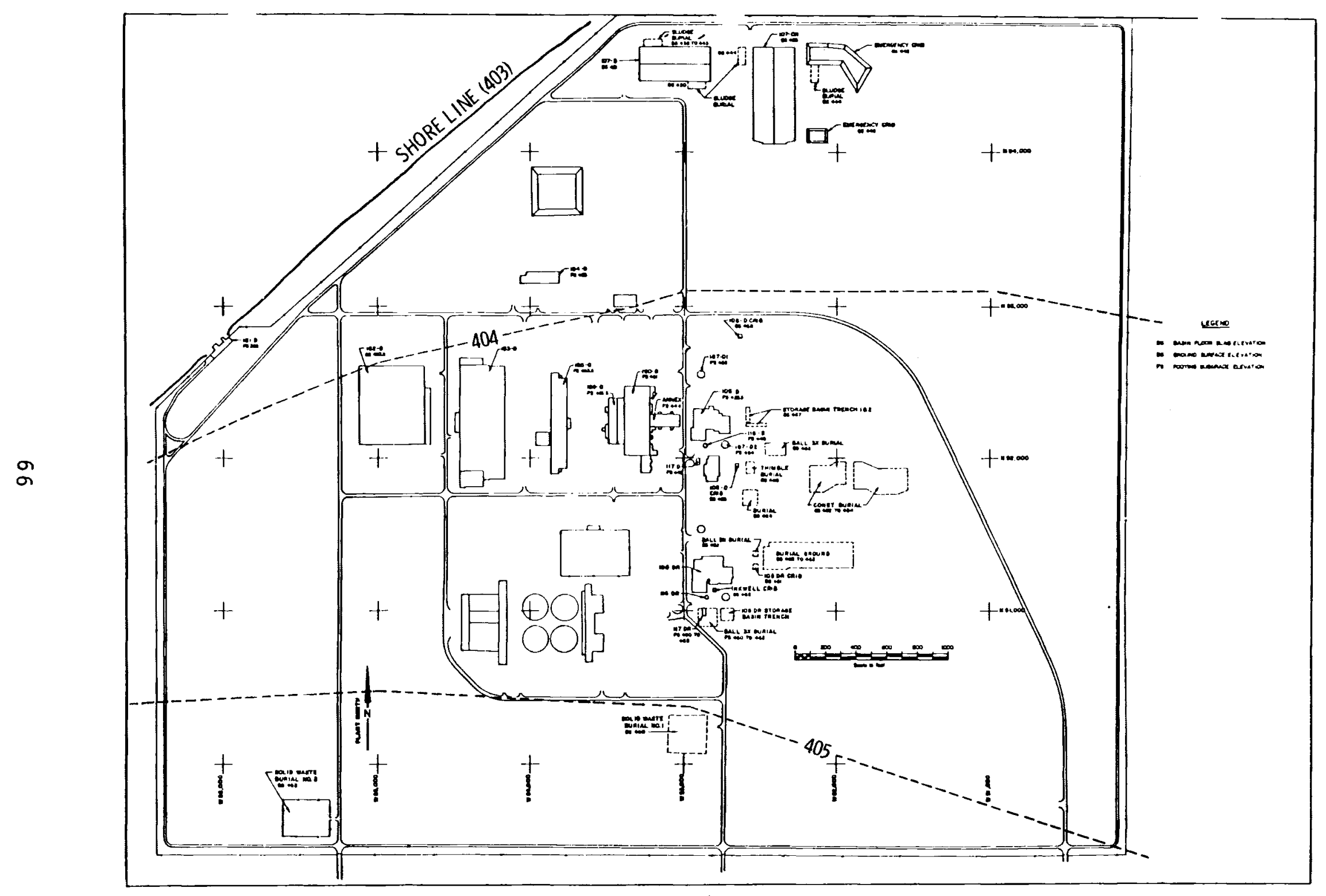

FIGURE 12. Predicted Water Table Contours 400-Foot Ben Franklin Pool Elevation 300,000 cfs Flow, 100-D Area 
The changes in effective stress due to a raising of the groundwater table in the typical foundation material would theoretically induce a settlement that would be at most only a fraction of the previous settlement under the actua? load. Settlements of this order could reasonably be described as imperceptible and insignificant and are of no concern. This leaves, however, two nontypical conditions to be considered.

The two nontypical conditions were collapse of wind laid silts and silty sands upon inundation, and liquefaction of saturated loose fine sands during earthquakes. These two conditions are discussed in Task 2 of this report. Liquefaction is also discussed briefly in the following section.

\section{Soil Liquefaction}

Liquefaction of saturated cohesionless soils by seisinic disturbances has been found to occur in soils typical of some parts of the Hanford Site. One place is near the WPPSS sites 1,2 and 4 where the top 60 feet (approximate) of medium dense to very dense sand was judged to be susceptible to liquefaction from the Safe Shutdown Earthquake (SSE).

The Shannon and Wilson report for the WPPSS plant (known as WNP-1) to be located at 100-N area cited test borings, excavations, and seismic velocity surveys, made at $100-\mathrm{N}$, and concluded:

Based on this investigation, it is concluded that the foundation soils are not susceptible to loss of strength, subsidence or liquefaction resulting from motions associated with the Safe Shutdown Earthquake.

This, along with other observations in previous reports, indicates that the other nearby reactor sites of 100-B, D, and $K$ Areas may not be susceptible to the liquefaction phenomenon, particularly since the groundwater rise would be only a few feet. However, to be certain, soil surveys are required to establish the composition, density, strength, and other properties of the soils underlying these reactor sites.

Hydrostatic Uplift

The predicted groundwater levels are high enough that the retention basins at $100-F$ and $100-H$, the storage basins at $105-F$ and $H$, the $184-F$ and $H$ ash pits, and several suction wells at the 100-F and 100-H Areas would be 
subjected to hydrostatic uplift. Actually, the bottom slabs of the retention basins, which already have about 4 feet of earth fill to hold contamination in place against wind action, have numerous cracks that might let the water in rapidly enough to nullify the uplift. The same is true of the buried concrete and steel effluent lines, which probably have leaky joints in the concrete lines and Dresser couplings in the steel lines. These lines open into the basins and river. However, watertight and nonleaking storage basins (fuel element storage) and pump suction wells in the water treatment buildings would definitely experience uplift forces. These could also be protected from uplift by filling with earth.

The previous studies had identified the 107-B and 107-C retention basins as being subject to uplift. Now, however, the predicted groundwater elevations in the 100-B Area are about 16 feet lower and these basins and footings would not be affected.

Consolidation of Backfill

Earlier studies pointed out that consolidation of uncompacted or poorly compacted backfill frequently occurs as a result of inundation. This phenomenon should be anticipated in areas which become wetted by a rise in groundwater. Structural components or piping supported by backfill would be expected to settle significantly. In some cases, this can rupture the piping. This occurs when pipes are supported by a basement wall and sag when the backfill settles. Should the pipes contain radioactive material, it could be released to the ground. Ruptures have occurred in the past in lines constructed of brittle materials such as cast iron, concrete, and vitrified clay at Hanford facilities from backfill settlement next to buildings brought about by heavy rains.

Generally, major building foundations at Hanford are placed on undisturbed ground or lean concrete placed in over-excavated areas beneath foundations. Settlement of backfill placed next to structures and placed over (and under) buried pipes could be expected to be most noticeable at the 100-F and 100-H Areas, which become partially flooded. The backfill next to the river pumphouses, such as $181-\mathrm{F}$ and $181-\mathrm{H}$, could be expected to settle. This 
would create unequal loading on the structures from the higher' load of the soil-plus-water material on the shore side compared to the hydrostatic load of water only on the river side.

In the other areas, the higher groundwater levels would affect only the backfill placed in low elevations near the river bank, such as next to the river pumphouses and outfall structures.

Change in Earthquake Response of Structures

The main effect of the Ben Franklin Dam on the seismic response of existing Hanford structures would be due to the change in the water table. Raising the level of saturation in the primarily cohesionless soil layers overlying the basaltic bedrock would have two identifiable results: liquefaction in the less confined upper layers in sands of certain size ranges (addressed in the Task 2 section) and an alteration of the soil dynamic properties such as wave transmission characteristics of the saturated soil layer. Seismic energy is transmitted through the soil media by dilatational (compression) and shear waves. Shear wave velocities are relatively unaffected by soil saturation. The effect is due primarily to the change in bulk density. The dilatational wave velocities, however, are increased significantly for typical Hanford subsoils and approach as a limiting value the sonic velocity of water. The result of a change in water table level would thus be a change in the phase relationship between the arrival of shear and compressive wave arrival at each surface location.

This change in phase would appear to be minor because, for most structures, the change in water table due to the presence of the dam would be a minor portion of the total depth of the saturated layer. The normal design procedure for most existing Hanford structures is to use a design response spectrum based on seismic and geological characteristics of the Hanford area. The design response spectrum is an envelope that characterizes maximum response of structures with respect to frequency and would usually be conservative enough that the effect of the minor change in water level would not compromise its validity. It should be noted, however, that most existing structures in the 100, 200 and 300 Areas were not designed to present-day seismic design standards. 
The incremental water table change may affect the immediate foundations of some of the 100 Area structures. This could have a serious effect for the more massive structures, where the above described changes in the soil dynamic properties may have a significant effect on the soil structure interaction during a seismic event. Again, most of the structures noted in this investigation may not have been analyzed in detail for soil structure interaction.

Generally, the seismic response to a postulated earthquake event, for many of the structures in this study, has not been evaluated in detail at the present state-of-the-art. To determine the probable effect of an incremental change in water table on their resistance capability would require an extensive determination of what the present capability is, and a reevaluation with the environmental change due to the Ben Franklin Dam. Included in this effort would be soil surveys and seismic wave velocity determinations. This effort is beyond the scope of this report, but it is an area that will require consideration in the final determination on the dam feasibility.

Transport of Radionuclides

Reactor operations at Hanford resulted in fuel element failures ("ruptures") in which some of the uranium metal and associated radioisotopes were sloughed off the element into the cooling water. These contaminants have been deposited along the effluent lines, in the retention basins, in the waste cribs, and in the special effluent lines leading to the cribs. The amount and distribution of these contaminants have been surveyed and documented by Dorian and Richards (1978).

The raising of a 400-foot MSL and subsequent periodic raising and lowering of the pool creates a possible problem with respect to these buried lines and retention basins. Transport of radionuclides from the vicinity of buried lines and infiltrated structures could arise from reservoir level variations, particularly in lines near the river, i.e., the effluent line from the retention basin to the river. These lines are open to the river and the water level would fluctuate in them as rapidly as the pool elevation. Loose contaminated materials, radioisotopes, rust, paint, etc., could be dislodged and introduced into the river. 
The movement of the material in groundwater from beneath 1 ines and retention basins is a different matter. Some of the material is fixed in the soil by ion absorption, and its movement by groundwater could be very slow, as stated in the Shannon and wilson study (1966) with reference to the 100-BC site.

At the $B C$ site, the contact between the highly pervious glaciofluvial sediments and the underlying Ringold formation of much lower permeability is estimated to lie between elevations 350 and 370 , we 11 below present river level at all stages. Under present conditions, river stage fluctuations immediately induce transient flow conditions in the pervious zone. With the Ben Franklin pool the same situation would exist but with a raised base groundwater level. The raising of the base level would enlarge the aquifer resulting in a closer approach to steady state conditions near the shore and a greater inland extent of the effects of river fluctuation. The maximum rate of riverward movement of groundwater would occur, as a present, during falling river stage. The volumetric rate of seepage would be greater than at present, because of the increased depth of the pervious zone above the Ringold but the gradients and velocities would tend to be somewhat less than at present. In our opinion, the net effect of these changes due to the Ben Franklin project on the travel time from a groundwater mound beneath a crib to the river would be insignificant. Although increased volumetric flow rates toward the river during falling stage would result, the difference would attach primarily to a return of the river water that charged the aquifer during rising stage rather than to the crib effluent. (underlines added).

In light of the underlined conclusions and the fact that these zones of contaminated material had water running through them to the river for several years, the transport of radionuclides from them to the river via groundwater would appear to be less likely or much slower than the washing out of material from the effluent lines between the retention basins and the river. The removal of contaminated materials from cribs, leaks, etc., is discussed in the Facility Decormissioning section.

\section{SIGNIFICANT FINDINGS}

$100-F$ and $100-H$ Areas

By far the greatest effect of the pool waters on DOE structures at Hanford is the flooding of $100-F$ and $100-H$ areas. The $100-F$ area would be on an island. As described earlier, the foundations of many buildings, including the reactor buildings, water treatment buildings and retention basins, would be 
below the groundwater level. Others would be endangered by rising waters during flooding periods. Although it is not considered necessary from the standpoint of near-term structural integrity, these buildings should preferably be removed. If they are not removed, the settlement of the reactor buildings should be monitored to detect rapid or differential settlement, and basins, pump wells, etc., filled with earth to protect against hydrostatic uplift. As discussed in Task 2, soil borings to determine liquefaction potential should be made under the 105 buildings.

Current decontamination and decommissioning plans for Hanford include dismantling the major buildings in these areas. If this is done prior to raising the pool, the problem becomes academic. Estimates of the cost of decommissioning the $100-F$ and $100-H$ buildings are provided under Task 5 , Facility Decomissioning.

100 Area Effluent Lines

That part of the reactor cooling water effluent lines from the retention basins to the river which will be lower than the predicted groundwater levels should be removed down to about the present river level. An alternative would be to fix contamination in place by filling the lines with concrete or grout. Any pockets of contaminated material under them should also be removed or fixed in place. These lines are open to the river and normal pool fluctuations would tend to wash particles down the lines into the river. The outfall lines buried in the river bottom should preferably be left in place. Removing these lines could easily introduce more contamination into the river than leaving them there.

Soi 1 Liquefaction Potential and Earthquake Response, 100-B, K, and D Areas

The potential for soil liquefaction under earthquake acceleration at the $100-B, K$, and $D$ Areas is unknown, although it has been judged unlikely (Shannon and Wilson 1966; WPPSS 1978). Should the major buildings in these areas remain at the time of raising the pool, soil surveys should be made to assess the liquefaction potential under the conditions of the predicted groundwater table rise. A decision should be made as to whether the buildings constituted a risk far enough in advance to take corrective action. 


\section{Contaminated Lines in Backfill}

Lines through backfill which become saturated can be ruptured as described earlier. Such lines at the 100 Areas that could be contaminated would originate primarily at the reactor building and would include the cooling water effluent lines, other waste water such as drains from the storage basin overflows, wash pad area and waste lines from other decontamination operations. Other contaminated lines such as those to emergency cribs, and leaching trenches would not normally have been placed on backfill material. Those originating at the reactor building or known to be placed on backfill should be surveyed. Those identified as problem lines should be removed if the backfill would be saturated by the rise of the groundwater.

The present preliminary examination indicates that only lines in $100-F$ and $100-\mathrm{H}$ areas would be affected. The backfill around the reactor buildings in the other areas appears to be above the predicted level of the groundwater. A detailed search should be made for lines from other waste disposal areas that are in backfill and not accounted for here.

Other Areas - 200-E, 200-W, 300 and 400 Areas

The 200-E and 200-W Areas are at a ground elevation of about 700 feet. The water table rise predicted there is about 8 to 16 feet, bringing the level up to elevations ranging from 420 to 460 feet. The groundwater elevations predicted for 200-W area are less than those that have existed there in past years when larger amounts of water were being wasted. At 200-E area the rise is from about 405 feet to about 420 feet. The effect of the groundwater changes on both these areas is judged to be insignificant.

At the 300 Area the groundwater rise is predicted to be less than 2 feet, which would have negligible effects. The rise of about 20 feet to 400 feet elevation at the 400 Area (FFTF) where the ground elevation is about 550 feet, leaves about 67 feet from the groundwater to the lowest foundation. It is judged that the effects on structures there would similarly be insignificant. 


\section{Future Structures}

The raising of a 400-foot Ben Franklin Dam Reservoir has been judged to have a significant impact on the WPPSS Nuclear plants 1,2 and 4 because of the possibility of soil liquefaction of the top 60 feet under earthquake motions. The same effect is thus anticipated for any future Department of Energy structures desired to be located near those WPPSS sites or on sites having similar soil conditions and subject to a similar rise in groundwater levels. Although no specific costs can be attributed to such a restriction at this time, it can be noted that the extra cost to provide deeper foundations, waterproofing of structures, and special compaction of backfill for the WPPSS reactors was about $\$ 1.90 /$ cubic yard for excavation and compaction and $\$ 10.00 / \mathrm{sq}$. ft for water stop. (a) A typical cost for membrane waterproofing is in the range of $\$ 0.81$ to $\$ 1.30$ per sq. $\mathrm{ft}$. The total cost of the special work at WNP 1 and 4 is estimated at about $\$ 2,000,000$.

The Ben Franklin pool could also affect the Basalt Waste Isolation Program, should it be decided to utilize and locate this concept at Hanford. No cost can be estimated at this time but the possible effects of the Ben Franklin pool should be evaluated for this program. The estimated groundwater rises ranging from about 10 to about 46 feet could require more extensive waterproofing for portions of such a geologic storage facility.

\section{$\underline{\text { RECOMMENDATIONS }}^{(b)}$}

\section{Flooding}

It is recommended that the extent of the inundation of reactor and 300 Areas under a probable maximum flood of $1,440,000$ cfs at the Hanford Reach be determined for the conditions of no dam and the proposed dam. (c)

\section{$\underline{100-B-C \text { Area }}$}

Predicted groundwater levels are 408 to 409 feet at 300,000 cfs. The lowest structural item, aside from effluent lines, outfall structures and the

(a) These cost figures were provided by A. Hossler of WPPSS.

(b) Burial grounds and cribs are not covered here; see the Task 5 Facility Decomissioning section.

(c) Estimated costs for the recommendations contained in this section are summarized at the end. 
river pump house, is the 107-B retention basin bottom at 422 feet. The river level is at 407 feet at 300,000 cfs and at 415 feet during a standard project flood of $570,000 \mathrm{cfs}$.

No problems are anticipated for structures except effluent lines. It is recommended that cooling water effluent lines (that part which extends from predicted high groundwater level to existing river level) be removed or the contamination fixed in place.

\section{0-K Area}

Predicted groundwater levels are from 408 to 410 feet at 300,000 cfs (Figure 8). River level at $300,000 \mathrm{cfs}$ is 405 feet and during the standard project flood it is 413 feet. The floor level of the river pump house is 421 feet.

No problems are anticipated for structures except effluent lines. It is recommended that the effluent lines be remedied as recommended for 100-B-C area.

It is recommended that the concrete outfall structures at invert elevation of 404 feet and the overflow flume be surveyed for contamination. If any exists, it should be decontaminated or the contamination should be fixed in place.

It is recommended that process sewers and effluent lines to the crib next to the river with invert elevations of 405 feet and 412 feet be removed or otherwise remedied if contaminated.

\section{0-N Area}

There are no recommendations for 100-N Area. Predicted groundwater levels are 406 to 411 feet at 300,000 cfs (Figure 9). The footing subgrade elevation of the reactor building $(105-\mathrm{N})$ is 415.5 feet. The river pump house floor elevation is 421 feet. River level at 300,000 cfs is 404 feet and 410 feet during the standard flood.

No problems are anticipated for structures. Soil tests show no potential for liquefaction here. Because $\mathrm{N}$ area does not discharge contaminated water to the river, no problems are anticipated with the cooling water effluent lines. 


\section{$\underline{100-D \text { Area }}$}

Predicted groundwater levels are 404 to 405 feet at 300,000 cfs (Figure 10). River level is 403 feet at 300,000 cfs and 408 feet at 570,000 cfs. The river pump house floor is at 419 feet.

No problems are anticipated for structures except effluent lines. It is recommended that effluent lines be treated as recommended for 100-B-C. The outfall structure and overflow spillway should be decontaminated if any contamination exists.

\section{$\underline{100-H \text { Area }}$}

The predicted groundwater levels are about 403 to 404 feet (Figure 8). River level will be at 402.5 feet at 300,000 cfs and at 570,000 cfs it is about 406 feet. Parts of $100-\mathrm{H}$ area are flooded (see Figure 8 ).

It is recommended that the major buildings in the $100-\mathrm{H}$ Area be dismantled prior to filling the reservoir. If they are not, the settlement monitoring recommended by Ballowe (1967) should be performed. All effluent and process sewer lines should be removed or have the contamination fixed in place. Also, the 107-H retention basin slab at 396 feet should be covered with an additional 3 feet of earth to balance hydrostatic uplift. Other basins and galleries listed in Table 2 should also be filled to balance hydrostatic uplift. It may be desirable to remove all buildings from the $100-\mathrm{H}$ Area prior to filling the reservoir pending a more detailed study of dismantling under flooded conditions.

Several other buildings in the 100-H Area are in danger of flood because their lowest elevations are near or below predicted groundwater levels, particularly during flood stage. Table 3 lists these additional endangered buildings. Other smaller structures are not included in Table 3; a complete listing of buildings that should be removed is available in the facility Decommissioning section of this report.

\section{0-F Area}

The predicted groundwater levels are about 402 feet at 300,000 cfs (Figure 7). River level would be 402 feet at 300,000 cfs and 404 feet at $570,000 \mathrm{cfs}$. Parts of $100-\mathrm{F}$ are flooded and the reactor and most other buildings would be on an island. 
TABLE 2. Reactor Building, 100-H Area

(water table elevation 403 to 404 feet)

Item

Floor Elevation (feet)

Transfer Area

General Area Floor $\quad 397$

Pits (South of Basin) 398

Sump Area $\quad 396.5$

Miscellaneous Chambers 397-402

Wash Pad Pit 402

Viewing Basin Galleries $\quad 402$

Storage Basin

Basin Floor $\quad 402$

Sump 400

Process Area

South Part $\quad 402$

Tunnel Sump (Gas Recirc. Wing) 403

Galleries $\quad 402$

TABLE 3. Buildings in 100-H Area Near or Below Anticipated Groundwater Levels During Flood Stage (406 feet a 570,000 cfs)

\begin{tabular}{|c|c|c|}
\hline & Building & Elevation Feet \\
\hline \multirow[t]{4}{*}{$182-H$} & Reservoir & \\
\hline & Bottom of Suction Well & 395.8 \\
\hline & Pump Room Floor & 400.0 \\
\hline & Bottom of Reservoir & 404.5 \\
\hline \multirow[t]{4}{*}{$183-\mathrm{H}$} & Filter Plant & \\
\hline & Bottom of Suction Well & 392.5 \\
\hline & Bottom of Clearwells & 402.5 \\
\hline & Pump Room Floor & 395.0 \\
\hline $190-H$ & Building - Pipe Gallery Floor & 408.0 \\
\hline $184-H$ & Steam Plant - Ash Pit Floor & 406.5 \\
\hline $181-\mathrm{H}$ & River Pump House - Pump Room Floor & 409.0 \\
\hline $116-\mathrm{H}$ & Ventilation Stack - Footing Subgrade & 405.0 \\
\hline \multirow[t]{3}{*}{$117-\mathrm{H}$} & Confinement Filter Bldg & \\
\hline & Sump & 399.0 \\
\hline & Lowest Level Floor & 401.0 \\
\hline
\end{tabular}


The same assumptions and recommendations listed for 100-H Area apply to $100-F$ Area. If the buildings and other facilities are not removed, the effluent lines and process sewers should be removed or remedied as recommended for 100-H Area. According to Dorian and Richards (1978), the 107-F retention basin slab at 399 feet has been covered with 4 feet of earth fill, which is sufficient to balance hydrostatic uplift. The 117-F confinement filter building would need protection against uplift with its lower floor at 384 feet. Basins and galleries in the $105-F$ reactor building requiring protection against uplift are listed in Table 4.

TABLE 4. Reactor Building, 100-F Area

(Water Table Elevation 402)

\section{Item}

Transfer Area

Pits adjacent to storage area

389

Chambers - north side of pits

Storage Area

Basin

392

Process Area

Lower Floor

393

Elevator Shaft

Counterweight Shafts

Valve Pit

Floor

Pit and sump

Fan House

Pits and Galleries
Floor Elevation
397

400

$398-400$

399.5

397

Other buildings which would be in danger of being inundated in flood stages include those listed in Table 5. 
TABLE 5. Buildings in 100-F Area Near or Below Anticipated Groundwater Levels During Flood Stage (404 feet a 570,000 cfs)

\begin{tabular}{|c|c|c|}
\hline & Building & Elevation - Feet \\
\hline $181-\mathrm{F}$ & River Pump House - Pump Room Floor & 405.0 \\
\hline \multirow[t]{4}{*}{$182-\mathrm{F}$} & Raw Water Reservoir & \\
\hline & Bottom of reservoir & 404.0 \\
\hline & Pump room floor & 401.0 \\
\hline & Bottom of pump room suction we 11 & 397.25 \\
\hline \multirow[t]{3}{*}{$1830 \mathrm{~F}$} & Filter Plant & \\
\hline & Bottom of suction well & 398.0 \\
\hline & Pump room floor & 400.5 \\
\hline $190-\mathrm{F}$ & Process Pump House, Valve Pit & 399.5 \\
\hline $184-F$ & Boiler House, Ash Pit Floor & 400.5 \\
\hline $115-\mathrm{F}$ & Gas Filter Building - Tunne 1 & 402.5 \\
\hline \multirow[t]{2}{*}{$116-F$} & Ventilation Stack - Grade Elevation & 405.0 \\
\hline & Footing Subgrade & 387.5 \\
\hline \multirow[t]{3}{*}{$117-F$} & Confinement Filter Bidg. & \\
\hline & Filter Chamber Floor & 384.0 \\
\hline & Sump & 382.0 \\
\hline
\end{tabular}

Previous studies (Shannon and Wilson 1966; Ballowe 1967) stated that significant adverse effects on the $100-\mathrm{H}$ and $100-\mathrm{F}$ area structures were too remote to justify protective measures, but that their settlement should be monitored. There is no reason to change that conclusion. The recommendation that the buildings in these areas should preferabiy be removed is based on the reasoning that environmental considerations would make it impractical and imprudent to leave a contaminated nuclear reactor facility in a partially flooded condition and partially or completely surrounded by river water. Consideration was also given to the fact that buildings which will be partly below groundwater level or located on an island after raising the pool will be inordinately difficult and considerably more costly to remove. 


\section{ESTIMATED COSTS}

The estimated costs of the recommended corrective action, surveys or studies are as follows:

Item

Design and planning

Sett lement monitors ( $F$ and $H)(a)$

Filling of basins and galleries $(F \text { and } H)^{(a)}$

Removal of effluent lines

Soil surveys for liquefaction potential (b)

$100-8 C$

$100-K$

$100-D$

$100-H^{(a)}$

$100-F^{(a)}$

Removal of contaminated lines

in backfill $(F \& H)(a)$

Flooding study
Cost Estimate

$\$ 50,000$

15,000

660,000

See Facility Decommissioning section

$80,000^{(c)}$

$80,000^{(c)}$

$80,000^{(c)}$

40,000

40,000

$\$ 250,000-500,000^{(d)}$

30,000

Estimated costs for building removal at $100-\mathrm{F}$ and $100-\mathrm{H}$ Areas are in the Facility Decommissioning section.

No costs are estimated for seismic analysis due to a possible change of earthquake response of structures because it is not now known which, if any, buildings will still be in place at the time of raising the pool, or what the results of a seismic soil survey would show with respect to the need for further analysis.

(a) These costs will be incurred if the $100-\mathrm{F}$ and $100-\mathrm{H}$ buildings are not dismantled before a Ben Franklin Pool is raised.

(b) These costs are also listed in Recommendation 2 of Task 2.

(c) An additional $\$ 50,000$ per reactor site would be required for a large lined shaft should the initial boreholes indicate the need for additional sampling. It is our opinion, shared by Shannon and Wilson, that the second shaft would probably not be required.

(d) Assumes all lines from reactor buildings are contaminated and must be removed. 


\section{REFERENCES}

Ballowe, J. W.. Ben Frank lin Dam Study Final Report - I. 1967. DUN-2349, Douglas United Nuclear, Richland, WA 99352.

Dorian, J. J., and V. R. Richards. 1978. Radiological Characterization of the Retired 100 Areas. UNI-946, United Nuclear Industries, Richland, WA 99352 .

Energy Research and Development Administration. 1975. Final Environmental Statement, Waste Management Operations, Hanford Reservation, Richland, WA. ERDA-1538, Energy Research and Development Administration, Washington, DC.

Haney, W. A, ed. 1967. The Effects of Ben Franklin Dam on Hanford.' BNWL-412, Pacific Northwest Laboratory, Richland, WA 99352.

Jaske, R. T. 1968. A Preliminary Evaluation of the Thermal Effects of the Ben Frank lin Dam Project on Columbia River Temperatures Below the Hanford Plant. BNWL-733, Pacific Northwest Laboratory, Richland, WA 99352.

Shannon and Wilson, Inc. 1966. Report on Soil Stabilization Studies, Hanford Reactor Sites with Reference to Ben Franklin Dam. Douglas United Nuclear, Inc.

U.S. Army Corps of Engineers. Ben Franklin Dam Study Reservoir Water Surface Profiles, File D-7-6-27.

U.S. Army Corps of Engineers. 1969. Memorandum Report Columbia River Basin Lower Columbia River Standard Project Flood and Probable Maximum Flood. North Pacific Division, Portland, OR.

U.S. Army Corps of Engineers. 1969. Ben Frank lin Lock, Dam and Reservoir. Seattle District.

Preliminary Safety Analys is Report for WNP-1, Washington Public Power Supply System, (Prior to Amendment 9). 1973.

Final Safety Analys is Report, WPPSS Nuclear project No. 2, Vo1. 2, Washington Public Power Supply System, updated 1978. 


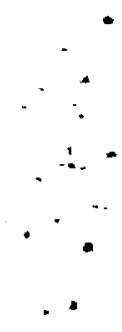

$\because$ 
TASK 4: ASSESSMENT OF POTENTIAL LANDSLIDING AND EROSION ${ }^{(a)}$

PROBLEM STATEMENT

The construction of Ben Franklin Dam at river mile 348 on the Columbia River will create a reservoir that will extend lipstream to the tailwater of Priest Rapids Dam at about river mile 396. The maximum pool elevation is expected to be 400 feet MSL, and use an operating range of about 10 feet between elevation 390 to 400 feet MSL. The reservoir will correspondingly increase the base level of the water table causing saturation of the adjacent bankline material to a higher level. The increased groundwater table could possibly reach weak and loosely consolidated soils and set up conditions for large-scale slope failures or rapid moving landslides, particularly if seismic disturbances occur.

- The raising of the groundwater level by constructing reservoirs contributes to slope failures in the following ways (Cedergren 1967): reducing or eliminating cohesive strength; producing neutral pore water pressures which reduce effective stresses, thereby lowering shear strength; producing horizontally inclined seepage forces which increase the overturning moments and the possibility of failure; lubricating failure planes after small initial movements occur; and supplying an excess of fluid that becomes trapped in soil pores during earthquakes or other severe shocks, leading to liquefaction failures.

The area within the Hanford Reservation where the possibility of such slides exists is a bluff line about 250 to 300 feet above the water surface of the Columbia River, and extending from river mile 376 downstream to about river mile 355 along the left bankline. The area, commonly referred to as the White Bluffs, is composed of ancient flood plain and shallow lake deposits (Ringold Formation). These deposits are unstable when saturated and will erode by undercutting when exposed to the action of laterally flowing water.

If 1 arge masses of bank material were to slide into the reservoir, partial blockage of the channel could result, forcing the main channel over

(a) W. H. Waltors and R. E. Brown 
toward the right bankline, where deactivated reactor sites are located. If the slides were to be generated by earthquake shocks, the failures could be rapid and possibly cause complete blockage of the channel and damage to structures located in their path.

The objective of this task is to assess the probability of bank erosion and/or landsliding within the confines of the Hanford reservation, and determine if the construction of Ben Franklin Dam will enhance this probability.

\section{SCOPE OF INVESTIGATIONS}

Aerial photo coverage of the Hanford Reach, Columbia River, supplied by the Corps of Engineers, Seattle District, was used in a preliminary assessment of bank erosion problems, and to plan the field investigations.

Using stereo pairs, previous landslide areas and areas with landslide potential were identified. Critical areas that would provide the best information regarding slide potential were identified for detailed field reconnaissance. Based on data from the photographs, an area of the White Bluffs, extending from about river mile 373 downstream to about river mile 367 (Figures 13 and 14), was identified as having experienced some very recent slides. There was also evidence of seepage at many locations along the bluff line located a little above the mid-elevation of the bluff face. This area was selected for detailed field investigations. Because field studies of slide areas must be conducted on foot, a complete reconnaissance of the Hanford Reach was beyond the scope of this task.

The right or opposite bankline from the White Bluffs consists of alluvial deposits, which are primarily sand and very loosely packed. There was no evidence of significant erosion discernible in the aerial photos. With a reservoir elevation of 400 feet MSL, the water's edge will be much further inland. An evaluation of the future location of the reservoir perimeter along the right bankline was beyond the scope of this task. However, a two-day reconnaissance of the present bankline was conducted to verify impressions gained from the aerial photography. 


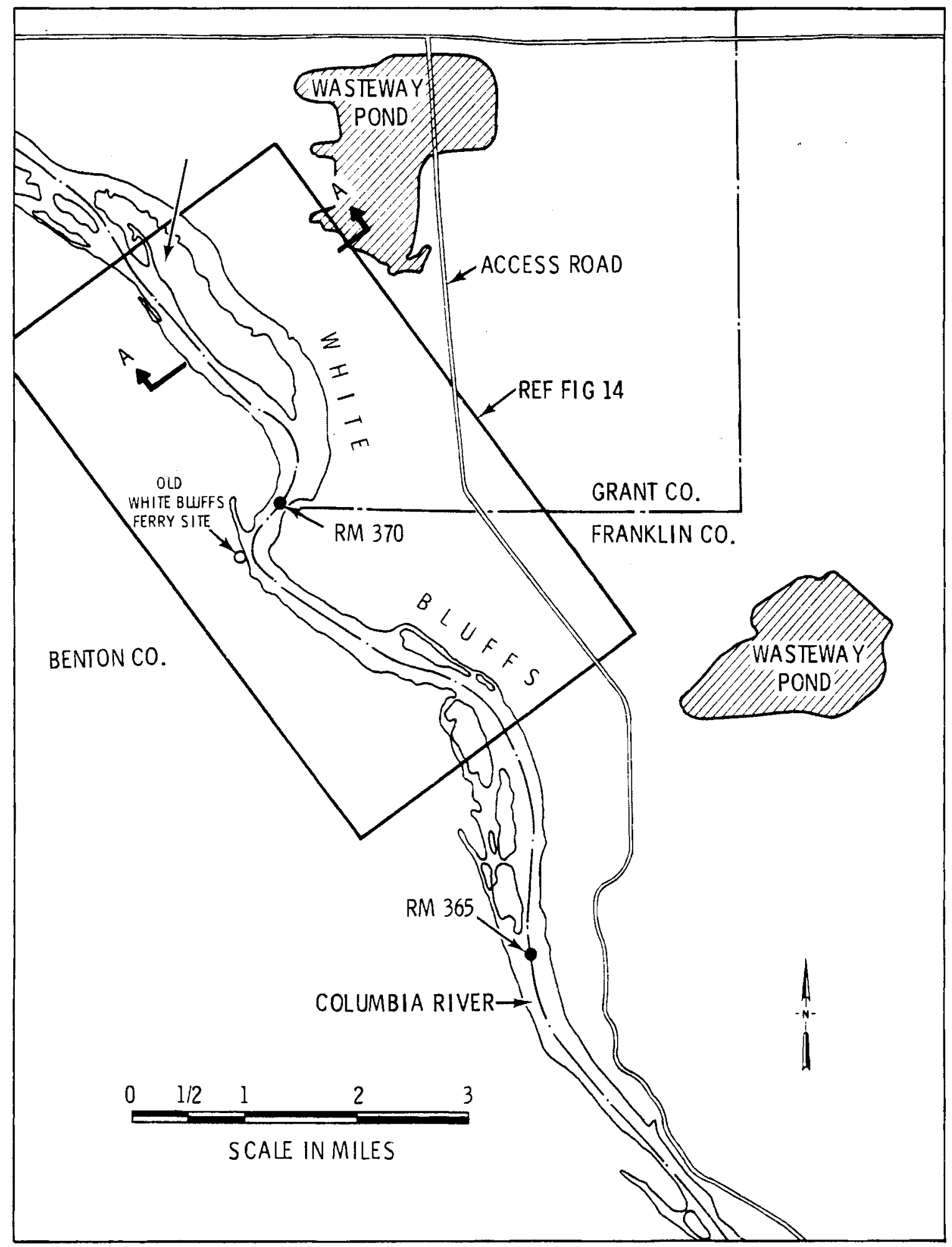

FIGURE 13. Location Map Showing Area Covered by Figure 14. 


\section{BEN FRANKLIN DAM STUDY}

ASSESSMENT OF POTENTIAL LANDSLIDING AND EROSION

$\stackrel{\infty}{\infty}$

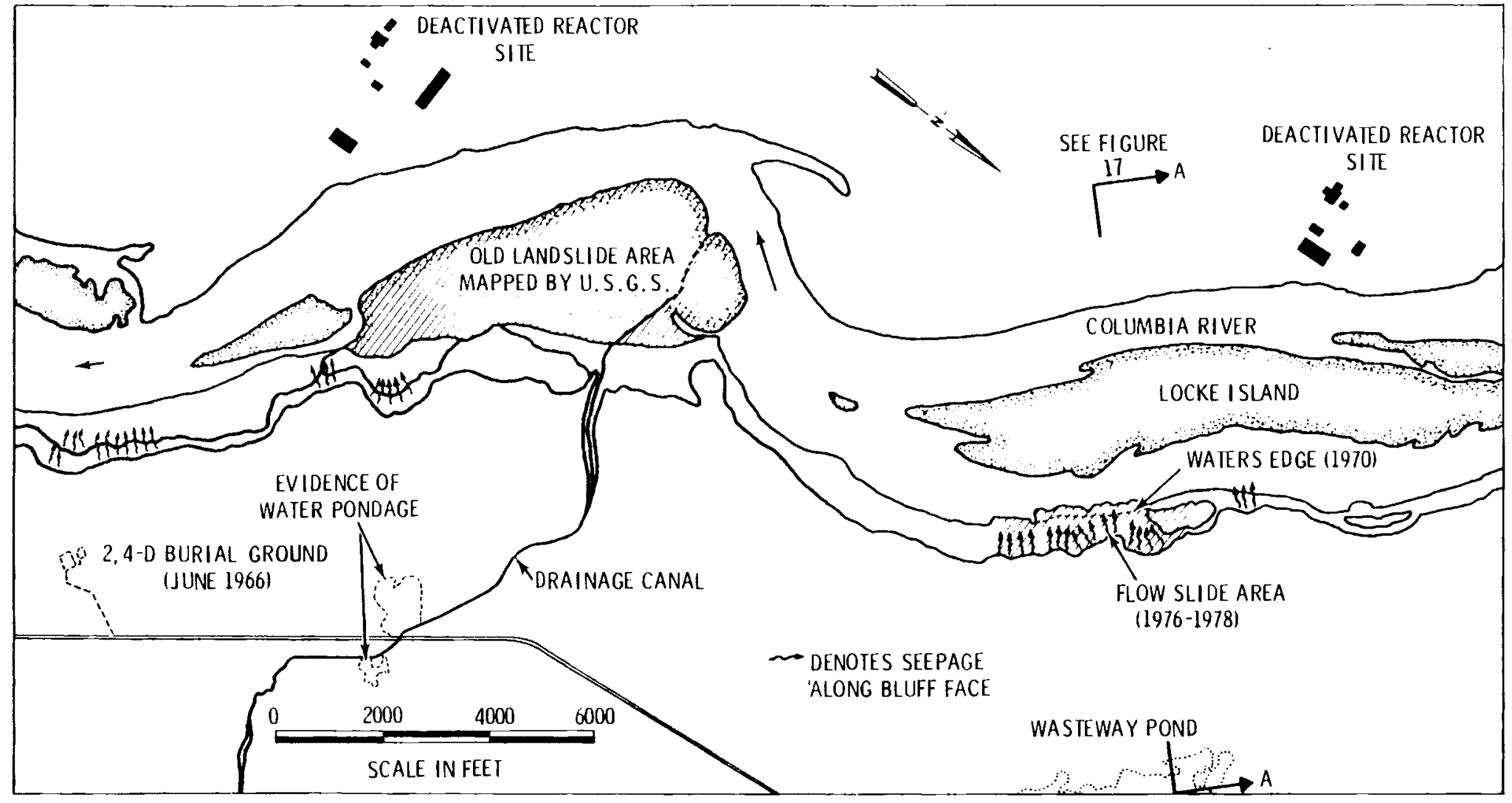

FIGURE 14. Landslide and Groundwater Seepage Locations as Mapped from Aerial Photograph (See Figure 13 for general location) 
The findings of this task were based on previous studies, an assessment of the White Bluffs geology, and field investigations.

Review of Earlier Studies

The authors were unable to find any published reports concerning the stability of the White Bluffs. However, a letter report by Shannon and Wilson, Inc., of Seattle, Washington, dated April 15, 1968, does discuss some possibilities based on a two-day reconnaissance of the Columbia River within the Hanford Site. Their findings are summarized as follows.

The report discusses about 13 river miles of bluff line, beginning at the downstream end with the old White Bluffs Ferry site (Figure 1). The river is described as flowing against the toe of the bluff, and the bluff is slowly retreating, principally by periodic minor sloughing caused by the oversteepening due to the lateral erosion of the river. A number of small slides are mentioned as having occurred along this reach. All of the sloughing and sliding is described as occurring within the Ringold Formation. The most significant observation concerns a 15 to 25-foot thick layer consisting of reddish silt and fine sand, which the report calls a "red bed," located within the Ringold Formation. At the northern end the layer is about 60 feet above the river level, and dips at a slightly steeper gradient than the river in the downstream direction. Due to this steeper gradient it passes beneath the water surface near the White Bluffs site. The layer is described as acting as an impervious membrane where groundwater becomes perched upon it and moves riverward from the Wahluke Slope to the north.

With reference to a slide history along the bluffs, the report states there is unmistakable evidence of sliding which has occurred sometime in the past along the toe of the bluffs downstream from the 0ld White Bluffs Ferry site, creating a flat area at the base of the bluffs.

The report concludes, based on the evidence of past sliding, and assuming the continuity, thickness and slope of the impervious layer, that an increase in groundwater probably will result in more sliding. The report further states that this is in part confirmed by the history of irrigation and sliding 
that has occurred at various locations downriver from Hanford, in higher overlying beds of varying permeability and not in the above-mentioned layer. Concerning the possibility of more irrigation development, the letter report offers the following conclusion:

The U.S. Bureau of Reclamation is now advancing a large irrigation ditch to the westward along the Wahluke Slope north of the old Wahluke Ferry site. It is planned to irrigate a strip of land between the ditch and State Highway 24. This will introduce into the soil groundwater that will move down the dip of any pervious members in the Ringold, and it seems almost certain that the red beds and some of the overlying strata will become saturated by infiltration of irrigation water, and just as certainly additional landslides can be predicted.

Regarding the types of slides expected, the letter report states:

There are two possible modes for landslides, i.e., 1) a series of shallow steep slides which would cascade into the river with the material pulverized and rapidly eroded by the river or 2) a few very large, massive and slow moving slides which would move into the river diverting it away from its east bank and which because of the mass would require some time for erosion by the river to restore its original channel.

With the advent of irrigation we believe the second mode of landslide is the more critical, and based on limited information, the more likely.

\section{Geology of the White Bluffs}

The White Bluffs are composed of Ringold Formation sediments, predominantly if not wholly of Pliocene age, hence more than several millions of years old. The sediments were laid down in a shallow lake and on a floodplain as the Pasco Basin subsided, and as the Horse Heaven Hills to the south rose, flattening the gradient of the Columbia River. As deformation continued, the river rose to correspondingly higher levels, gradually filling the basin to a depth of about 1000 feet before river overflow through the hills eroded Wallula Gap. During continuing deformation, the sediments were very gently tilted so that in the White Bluffs today they dip westward to southwestward at very low angles toward the basin center.

Following deposition, the Columbia River actively downcut and eroded the formation west of the White Bluffs, leaving those bluffs as remnants of the former deposit. The Columbia, the base level for the groundwaters, also lowered the regional water table as it lowered its course. 
The formation consists of silts, sands, gravels and clays, with gravels predominating on the main stream areas in the basin center, and the finer sediments where the floodplains prevailed. In the White Bluffs area of interest, sands and silts predominate with local clay-rich horizons. The beds commonly are 10 to 50 feet thick.

Results of Field Investigations

\section{0-Area Reconnaissance (Right Bankline)}

The major area of concern along the right bankline of the Columbia River involves the deactivated 100-D Area reactor site and the close proximity of its retention basin to the river. The basin is located on a terrace at about the 460 foot MSL, contour elevation. Below this there are three intermediate terraces at approximately 20 to 30-foot elevation intervals between the basin and the river. All the terraces are composed primarily of cobble and bouldersize material which ranges from $2 \frac{1}{2}$ inches to over 1 foot in diameter. The remaining smaller sized material consists of gravel with very small quantities of sand. The large stones are well-rounded and smooth, indicating transport and deposition by huge floods occurring during the last glacial age. Because the major portion of the material composing the terraces was deposited by glacial meltwater flows of unknown but enormous magnitude, it would take similar water discharges to re-entrain the material. For this reason, the right bankline at the 100-D Area is very stable. The Ben Franklin Dam reservoir would increase the water surface elevation to about the 400 foot MSL elevation, which would cause about a 10 to 20-foot increase in water surface elevation at the 100-D Area. River flow velocities would decrease, which would pose no threat to the bankline stability. Wave wash may loosen some material, but this would be insignificant. The increased groundwater elevation and its possible interaction with 100-0 Area radioactive wastes is not considered in this task.

Upstream from the 100-D Area the bankline material coarsens, which essentially means that more boulders are found in the sediment along with the usual cobbles and gravels. In the downstream direction, the amount of boulders observed in the bankline material decreased significantly and sand 
became more prevalent. However, gravel and cobbles were still present and composed the bulk of the material at the 100-H and 100-F Areas, with more sand at the $100-\mathrm{F}$ versus the $100-\mathrm{H}$ Area. The banklines at these two reactor sites are much flatter and erosion is not expected to be a concern.

\section{White Bluffs Reconnaissance (Left Bank)}

The recent mass sliding of bankline material into the river, as shown in Figure 14, began about 1975 or 1976, based on an interpretation of Corps of Engineers aerial photography. The imagery flown in 1974 did not show any evidence of slides, while 1976 imagery revealed at least three instances of what appeared to be flow slides where failure occurs due to a combination of saturation and a build-up of seepage forces from groundwater. No imagery was available for 1975. The imagery flown during March 1978, and field investigations conducted during October and November 1978, revealed that several more slides had occurred at the same location.

Mass movements of geologic materials on slopes are basically classified according to type of material (rock or soil), type of movement (falling, sliding or flowing), and to a lesser degree the shape of the slide itseif. Figure 15 shows a widely accepted classification currently in use. Three types of slides have occurred recently along the bluff location in question: 1) block glide, 2) debris avalanche, and 3) debris flow. The debris flow was by far the most common. Figure 16 shows simplified diagrams of the types of slides sketched from field observations. In some cases, the slides could be possibly classified as a debris avalanche and in other cases a debris flow; the debris flow indicates a wetter soil condition. Evidence suggesting that both types had occurred was illustrated by the hummocky topography at some locations, indicating a debris avalanche. In other locations a lobate-shaped tongue of material was present, indicating a debris flow. The debris flow failures move downslope as a viscous mass of soil and water, and spread out as they decrease their velocity. This was the most common type of movement with some slides overlying others. 

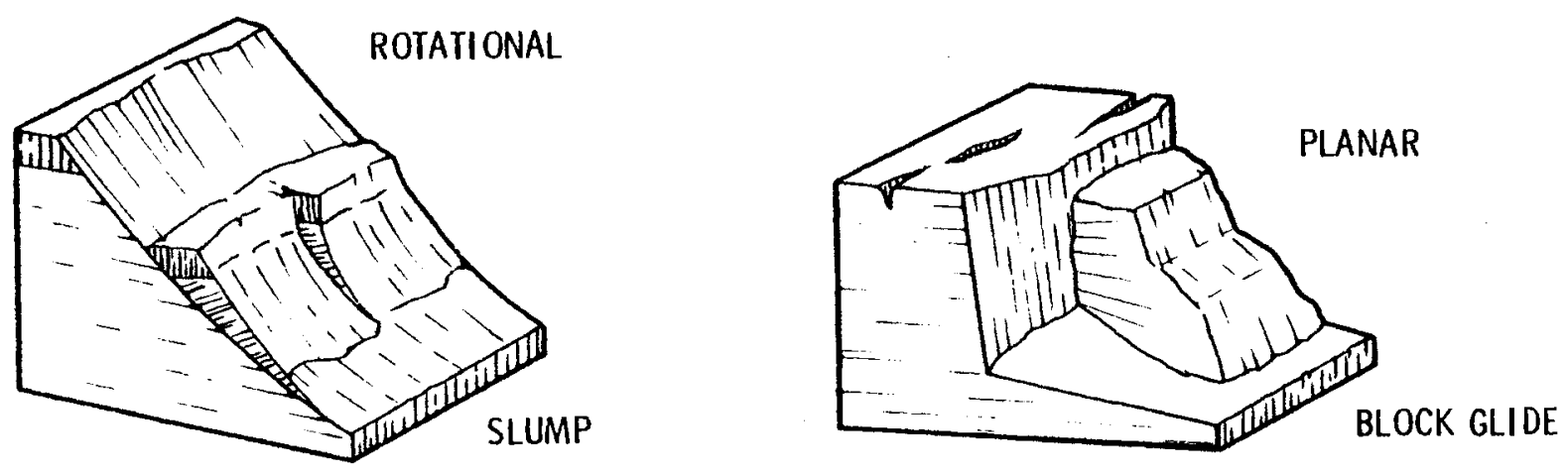

$\underline{0}$
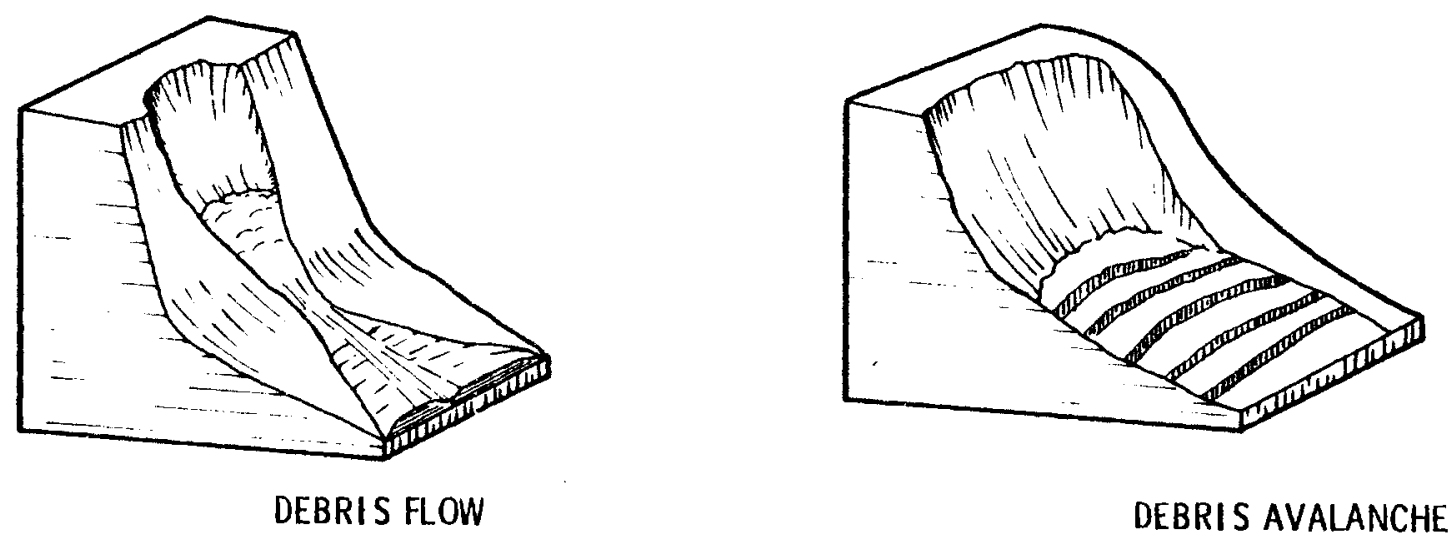

FIGURE 15. A Classification of Landslides (After Thornburg 1969) 


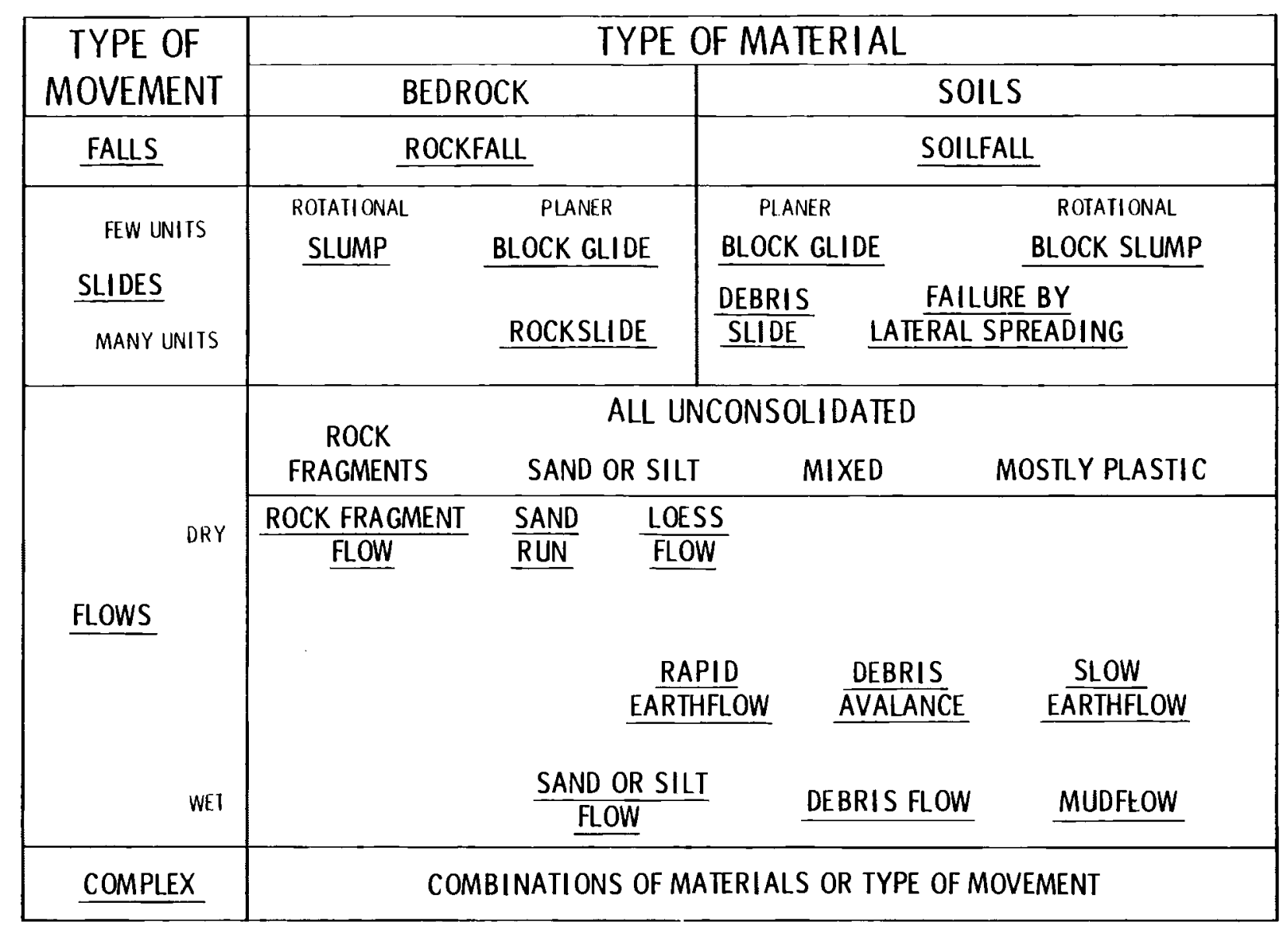

FIGURE 16. Simplified Diagrams of Landslide Types (After Leopold, Wolman and Miller 1964) 
The slides left a clean vertical bluff face on which seepage could be located. Groundwater seepage was occurring along a well-marked horizontal line about 60 feet below the top of the bluff. This was evidenced by discoloration of the bluff due to moisture, and in many cases it was marked by the growth of vegetation along the moisture line. Locations which showed evidence of recent seepage, both inactive and active, are marked in Figure 14.

The fact that seepage occurred only in the lower portion of soil masses may indicate that failure of that portion occurred as a debris flow and the dry upper portion immediately followed as a debris avalanche. The avalanche material also tended to remain at the base of the bluffs.

The occurrence of many slides at one location had created an apron of soil extending about 300 feet into the river at its maximum. During the course of field investigations, active erosion of the apron was occurring along the water's edge as evidenced by intermittent clouds of dust arising from the area. The cause was assumed to be the lateral flow of the river; however, periodic sloughing such as this could be also caused by a very gradual riverward movement of the soil mass. The sloughing produced a plume of very noticeable discoloration of the river extending outshore for a distance of 100 feet or more, and trailed downstream for more than a mile. The surface of the slide apron contained numerous cracks of more than 1 foot wide and was difficult to cross on foot. There were several feet of vertical displacement between individual fault blocks in some of the slides. In spite of the numerous surface cracks and fissures, each slide appeared to have moved as an individual mass of material.

The material around the perimeter of the slide area still in place was showing signs of instability along the upper bluff line in the form of cracks in some instances, and differential settlement of several feet in others. At one location, a large block of material had dropped about 4 to 5 feet along a slip plane at the base of the bluffs. This failure resembled the block giide type as shown in Figure 16 . The general shape of the block, the fact that it 
moved only a few feet, and the widespread occurrence of cracks and fissures along the crest of the bluffs behind the block indicate a possible block glide failure. The other possibility would be a rotational slump (Figure 16), or a combination of both types. However, the block glide failure appears to be more likely. Moisture was noticeable along one side of the block at its base.

Moisture due to seepage also appeared to be present along the toe of the bluffs, but these occurrences were not as obvious. At the locations where this seemed to have occurred the "red bed" described by Shannon and Wilson approaches the water surface (Figure 17). A gray clay layer about 10 to 15 feet thick overlays the red bed; it is upon this layer that moisture appears to be accumulating. The presence of moisture indicates the possibility that groundwater perched on this layer has also triggered some of the recent sliding.

Springs where water was actively flowing through natural outlets in the bluffs were found at three locations. At the toe of the bluff below each spring was a fan-shaped accumulation of eroded soil, indicating the internal migration of soil particles to an escape exit with the groundwater flow. The phenomenon can cause erosional failures and will probably worsen over time.

The source of the water for the springs and the seepage high up in the bluffs appears to be from emergency irrigation wastewater dumping ponds located about 1 to 2 miles upslope from the river. Water has been standing in the ponds since at least 1976, and probably longer, as stands of trees are accumulating around the pond boundaries. Observations of the ponds in the field indicated an average depth varying from 2 to 4 feet. The water from the ponds is perched on an impervious layer high up in the bluffs, and probably does not reach any other layers beneath this one, which would indicate more than one source of seepage water, since there was also evidence of moisture from seepage at the toe of the White Bluffs.

Another item requiring further investigation is a burial ground for herbicide 2,4-D about one-quarter mile or less from the face of the bluffs (Figure 14), and down gradient from wastewater dumping areas. The site was 


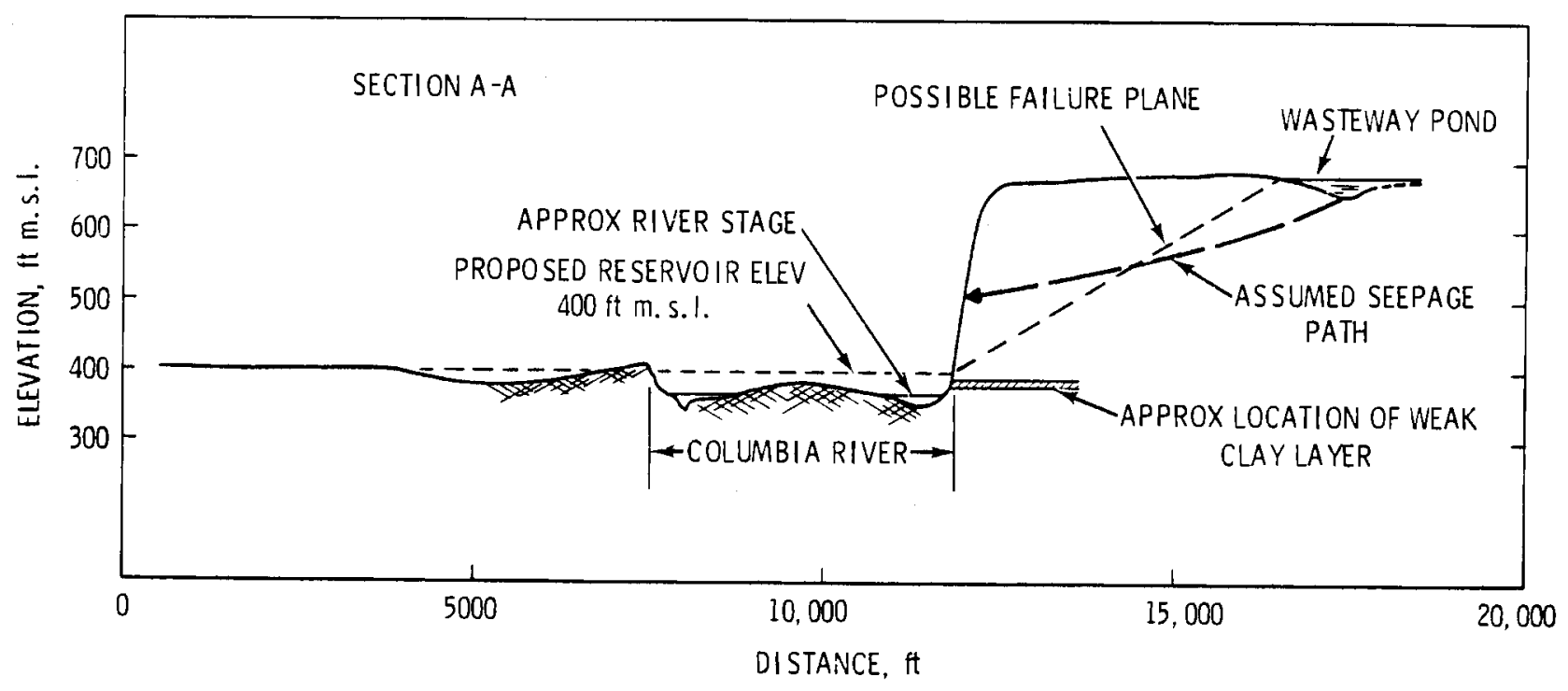

FIGURE 17. Cross Section Showing Approximate Relationship of Wasteway Pond Seepage, Weak Clay Layer, and Proposed Reservoir Level

marked by black and white signs showing the date of burial to be June 1966 . No investigation was made concerning the site.

Possible Effect of a Large Slide on Ben Franklin Dam

If a rapid large-scale slide were to take place after completion of the dam and reservoir, a solitary wave would be generated in the river channel which would move both upstream and downstream. The upstream wave would not be expected to cause a problem, but the downstream wave could cause damage at the dam site if it arrived with sufficient velocity. Henderson (1966) states that the velocity, $c$, of a solitary wave due to a single disturbance is given by the equation:

$$
c=g[(y+2 \alpha)]^{1 / 2}
$$

where the values of $y$ and $a$ are defined in Figure 18, and $g$ is the gravitational acceleration. Since $g$ is a constant, the wave velocity is 
primarily a function of undisturbed water depth, since wave height, $\alpha$, is usually small compared to depth.

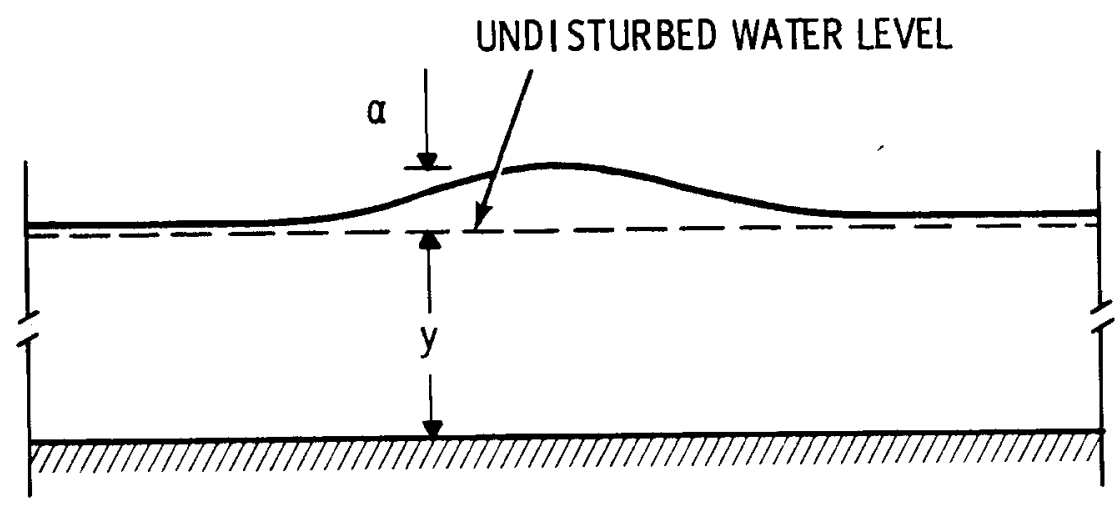

FIGURE 18. Definition of a Solitary Wave

If a large rapidly moving slide were to occur at the location of Section A-A (Figure 17), the above equation should provide a rough idea of the initial wave velocity expected for the first mile or so. It is rough in that no account of boundary resistance is taken in the equation, whose effect would presumably be to make the wave attenuate and disperse; that is, become lower and longer as it moves downstream. Also, there is the assumption that the equation does reasonably describe the phenomenon. Using a rough average depth estimate of the reservoir from the slide location downstream to the dam of 50 feet, and a moderate wave height of 5 feet, the wave velocity is computed as shown below:

$$
c=32.2[50+2(5)]^{1 / 2}=44 \text { feet per second }
$$

Based on the stated assumptions the above calculation indicates that a pressure generated wave would have an initial velocity of about 30 miles per hour. The maximum expected wave velocity at the dam would be much less than 30 miles per hour owing to the form and boundary roughness of the channel and the approximate 27 miles of distance the wave would have to travel. 
Summary

The foregoing is intended to convey the delicate balance between stable and unstable conditions which exists in the White Bluffs. It serves as a guide to the type and extent of bankslope failures to be expected if moisture continues to be imposed on the bluffs by a reservoir and/or continued irrigation. It indicates that there is a serious instability problem at this time.

\section{SIGNIFICANT FINDINGS}

The following significant findings apply whether or not Ben Franklin Dam is constructed:

1. The sources of water that appear to be causing instability problems in the White Bluffs are three-fold. Waste ponds near the faces of the bluffs receive emergency-dumped water, when canals are unable to handle local runoff. Other perched water evidently comes from irrigated 1 and a mile or more away, whether from that land itself or from wasteways. Still other seepage appears to reflect a regionally raised water table with base level on the Columbia. As a result conclusions concerning the instability problems of the White Bluffs are believed to apply whether the Ben Franklin Dam is constructed or not.

Much of the increased flow appears to enter the river at sites probably controlled by geological conditions, that is, relatively impervious soil layers upon which water can accumulate, thereby magnifying the effect of the higher water table.

2. The well developed bedding and alternation of fine grained sediments ideally accumulates (perches) groundwaters which migrate toward the face of the bluffs, the nearest natural drainage site. Amounts of water, perhaps ten times or more than that naturally falling on the land, is added through irrigated agriculture. It is believed that the water began reaching the bluffs a few years following the beginning of irrigation, and has been increasing, especially in the last 2 to 3 years. As water 
reaches the bluffs, landslides develop as the bluffs seek to reach a stable attitude.

3. The slides occurring on the left bank (Figure 14) have caused the bluff line to recede about 200 to 300 feet, with minor discoloration of the river. This discoloration could worsen if sliding continues. The slides are believed to be due to groundwater seepage forces and wetting of the soil mass.

4. The probability of a massive slide, such as that indicated in Figure 17, involving a soil mass extending as far back as the wastewater ponds, is enhanced under earthquake loading conditions. This appears to be very probably under " $g$ " loadings of 0.25 for 10 cycles or more, and would be due to liquefaction of a saturated portion of the soil mass. This topic is discussed in Task 2: Soil Liquefaction Analysis. Large slides such as these can move rapidly (20 to 30 miles per hour), completely block the Columbia River channel, and ride up the opposite bank. In this case, the main damage would be the blockage of the channel unless structures were encountered by the slide mass, in which case the damage would depend on several factors; namely, the size and speed of the soil mass and the size and structural integrity of the structures.

5. The sliding and erosion of soil masses along the White Bluffs is introducing large quantities of sand, silt, and clay into the Columbia River channel. This material could gradually be transported downstream to reactor or other cooling water intake systems causing siltation or plugging problems, or erosion to equipment due to increased sediment levels. The excavated trenches may act as sediment traps which would enhance the possibility of plugging or flow restrictions. While this may not be a problem at this point in time, with continued sliding or very large-scale sliding involving channel blockage, a problem may be expected.

6. No significant erosion problem has been identified along the right bank of the river. 
7. Potential problems arising from the 2,4-D burial ground were not investigated in this study. An investigations of the site is recommended.

The following significant findings apply if the Ben Franklin Dam is constructed:

8. A reservoir will further saturate and weaken the soil matrix in the bluffs. This is of particular concern in the present slide area where the gradually dipping clay layer is near the water surface without the reservoir. Figure 17 shows the estimated position of the layer with respect to the present and predicted water surface elevations. Therefore, earthquake loadings of lesser magnitude may cause large slides to occur. Not enough information regarding the geologic structure of the bluffs is available at this time to quantify any increase in the probability of occurrence of a large slide.

9. A reservoir will cause wave damage to shorelines at higher elevations and increase sedimentation problems, which may be only minor.

10. The reservoir will increase the possibility of interaction between the 2,4-D burial ground and groundwater flow. The possibility of groundwater interaction with the buried 2,4-D would be increased with a reservoir due to a raised water table base level. Because the depth and extent of burial is not known at this time, the possibility of 2,4-D entering the groundwater system cannot be evaluated.

\section{RECOMMENDATIONS}

The landsliding in the White Bluffs that has occurred was predicted more than 10 years ago, as previously discussed under "Review of Earlier Studies" in this task. The amount of sliding and the occurrence of mudflows, rather than block gliding or slumping, has been greater than expected. This is of greater concern than if slumping alone were occurring, owing to the high velocity of some mudflows, which reached from 30 to $40 \mathrm{mph}$ in nearby areas. The problem therefore is more serious than anticipated, and a more precise definition and location of causes are of more concern than before. 
The water sources are known. However, the relative importance and the long-term effects of each source are not sufficiently identified. Therefore, the following general recommendations are made:

1. Perched water from waste ponds and irrigated land can be identified and the magnitude of the problem largely determined by shallow test holes to demonstrated perching beds. At least 4 test holes were drilled by the U.S. Bureau of Reclamation, 10 or more years ago, for the observation of perched water bodies in the locale of concern. It is recommended that analysis of data from those wells be made to assist in identifying likely future events related to perched water drainage. For Task 4, drilling of other wells would be determined after an analysis of existing well data.

2. It is recommended that systematic surveys be made of the waste ponds, over a period of at least several months, to permit determinations of the local percolation rates. Thus, mapping of the ponds at periodic intervals, determination of the drop in levels, and correction for evaporation rates will identify the amount of water entering the ground.

3. It is recommended that the few deep wells in the immediate area be monitored to determine the changes that occur in the water table with time (and irrigation) and permit the determination of probable events.

4. The major points of emergence of the water table aquifer waters into the Columbia River appear localized 1 to 2 miles north of the East White Bluffs ferry landing (Wiehl Ranch locale). The seepage appears to be controlled by the dip and nature of the Ringold Formation sediments there. It is recommended that improved stratigraphic control be used to identify the causes of the sites of emergence.

5. The U.S. Geological Survey has mapped the Wieh1 Ranch areas as a gigantic landslide covered by alluvium (Newcomb et al. 1972). They did not discuss the area in their accompanying report. Other causes are also logical. However, if a slide has occurred there, its great size $(60,000,000 \mathrm{cu} . \mathrm{yd})$ is of concern in that another such slide may be possible. Shallow test drilling on the Wiehl Ranch area is recommended. 
Two test holes, about 100 feet deep each, should permit correlations identifying the origin of the slide. Thus, if the stratum correlates with upstream and downstream sediments, an origin other than sliding has occurred. If the sediments correlate with those higher in the bluffs, sliding has taken place.

6. It is recommended that the slide area be accurately surveyed together with the collection of undisturbed soil sampling. The samples would be laboratory tested to determine engineering properties of the soils. The results of the tests, together with survey information, would be used in an engineering analysis of the failures to provide information on seepage forces and factors of safety with respect to the occurrence of both past and future landslides.

\section{ESTIMATED COSTS}

The following estimate of work required to evaluate in more detail the landslide potential along the White Bluffs is itemized below. The study period is for 1 year and is restricted to the area within the limits of the Hanford Site. For Task 4 evaluations, a comprehensive monitoring system is not warranted nor cost effective at this time.

1. Evaluation of USBR Test Holes

Data collection and evaluation

$\$ 7,000$

2. Wastewater Pond Surveys

Surveying, mapping and evaluation

34,000

3. Monitoring of Deep Wells

Data collection and evaluation

17,000

4. Shallow Test Hole Drilling - Wiehl Ranch

Drilling, supervision and evaluation

11,000

5. Soil Sampling and laboratory Testing

Field sampling, lab analysis and report

80,000

6. Documentation

TOTAL $\quad \frac{5,000}{\$ 154,000}$ 


\section{REFERENCES}

Cedergren, H. R. 1967. Seepage, Drainage, and Flow Nets. John Wiley and Sons, Inc., New York, NY.

Henderson, F. M. 1970. Open Channel Flow. MacMillan Company, New York NY.

Leopold, L. B., M. G. Wolman and J. P. Miller. 1964. Flurial Processes in Geomorphology, W. H. Freeman and Co., San Francisco, CA.

Newcomb, R. C., D. R. Strand and F. J. Frank. 1972. Geology and Ground-Water Characteristics of the Hanford Reservation of the U.S. Atomic Energy

Commission. USGS Prof. paper 717, Washington, DC.

Thornburg, W. H. 1969. Principles of Geomorphology. John Wiley and Sons, Inc., New York, NY. 
TASK 5: FACILITY DECOMMISSIONING REQUIREMENTS ${ }^{(a)}$

\section{PROBLEM STATEMENT}

The objective of this section is to assess requirements for Hanford Facility decommissioning activities or modifications which may result from construction and operation of the proposed Ben Franklin Dam and reservoir.

Beginning in 1943, nuclear reactor plants for plutonium production were constructed along the Hanford reaches of the Columbia River where ample water for reactor cooling was available (Figure 1 ). The reactor plants were located in complexes (100 Areas) including the production reactors, pumping plants, water treatment facilities, power plants, reactor effluent retention and discharge systems, administrative offices, laboratories, and facilities for underground disposal of radioactively contaminated liquid and solid wastes.

By 1963, nine production reactors located in six areas were in operation (Table 6). This total included the N-Reactor, a dual-purpose production/power reactor, which supplies steam to an adjacent electrical generating $p l a n t$ operated by the Washington Public Power Supply System, as well as producing plutonium. Beginning in 1965 a gradual production facility shutdown was implemented, leaving only the N-Reactor currently operating. Four of the reactor plants ( $B, C, K E$ and $K W)$ are currently in standby status and four (D, $D R, F$, and $H$ ) are retired. The 105-KE and KW metal storage basins continue to be used for storing irradiated N-Reactor fuel elements, pending the proposed startup of the Purex reprocessing $\mathrm{plant}$. The biology research operations formerly located in the 100-F Area have been transferred to new quarters in the 300 Area. Most noncontaminated buildings have been removed from the 100- $F$ and 100-H Areas. The river pumphouses and water treatment facilities in the 100-B and 100-D Areas are used to supply water to the 200 Areas.

The 100 Areas are located on low terraces 50 to 100 feet above present river level and generally within a half-mile of the shoreline. Many structures, including several containing radioactive materials, are founded 10 to 25 feet below grade. In addition, columns of radioactively contaminated

(a) J. C. King 
TABLE 6. Hanford Production Area Current Status

\begin{tabular}{ll} 
Area & \multicolumn{1}{c}{ Reactor Plants } \\
\cline { 3 - 3 } 100-B & $\begin{array}{l}\text { B-Reactor } \\
\text { C-Reactor }\end{array}$ \\
$100-K$ & $\begin{array}{l}\text { KE-Reactor } \\
\text { KW-Reactor }\end{array}$ \\
$100-\mathrm{N}$ & $\begin{array}{l}\text { N-Reactor, WPPSS } \\
\text { Hanford Generating Plant }\end{array}$ \\
$100-D$ & $\begin{array}{l}\text { D-Reactor } \\
\text { DR-Reactor }\end{array}$ \\
$100-\mathrm{H}$ & H-Reactor \\
$100-\mathrm{F}$ & F-Reactor
\end{tabular}

B-Reactor shut dowr in 1968, C-Reactor in 1969. Both are currently in standby status with some equipment removed. 181-B river pumphouse in use for supply of export water to the 200 Areas.

KW-Reactor shut down in 1970, KE in 1971. Both currently in standby status. The 105-KE and 105-KW metal storage basins are being used for storage of $\mathrm{N}$-Reactor irradiated fuel elements. 181-KE river pumphouse is in operation.

In operation

DR-Reactor shut down in 1964, D-Reactor in 1967. Both are currently in retired status. Some noncontaminated structures have been removed. The 181-D river pumphouse provides a backup export water supply for the 200 Areas.

H-Reactor shut down in 1965 and currently in retired status. Most noncontaminated structures have been removed.

F-Reactor shut down in 1965 and currently in retired status. The 100-F animal $f$ arm and biology laboratory operations were transferred to the 300 Area in 1975. Most noncontaminated structures have been removed. 
soil extending to 30 feet below grade are found below liquid waste disposal facilities and reactor retention basin systems. Because of these characteristics the elevated surface and groundwater levels created by the proposed reservoir would require decommissioning actions to be taken on numerous facilities in the 100 Areas. Five potential problems were identified:

- release of radioactivity

- increased susceptibility to structural failure

- interference with future decommissioning activities

- attractive nuisances and concealed hazards near reservoir shorelines

- interference with the operation of active or standby facilities.

\section{SCOPE OF INVESTIGATION}

Specific criteria for decommissioning were established for each of the general problem areas identified above. Using these criteria and information on the physical and radiological characteristics of potentially affected facilities, facilities requiring decomnissioning action were identified. Sources of facility information included The Hanford Decommissioning Resource Book (Battelle, Pacific Northwest Laboratories 1975); The Radiological Characterization of the 100-Areas (United Nuclear Industries 1978); The Hanford Decommissioning Information System; site, engineering, and architectural plans; and field observation.

Following identification of potentially affected facilities, appropriate decommissioning action was determined for each. Estimated costs for these decomissioning activities were compiled, drawing where possible upon cost estimates made earlier for the Hanford Decommissioning Planning Project. Decommissioning Criteria

\section{Release of Radioactivity}

Construction of the proposed dam and reservoir would bring ground and reservoir waters into contact with radioactive materials in numerous locations in the 100 Areas. Because of the close proximity of these materials to the river, 
and projected rates of groundwater movement to the river, potential for release of radioactive materials to the river will exist. In addition, certain facilities containing radioactive materials would be partially or wholly submerged by the reservoir, presenting the possibility of direct release of radioactive materials to the river environment unless these materials were removed. Five conditions potentially leading to radioactive materials release were identified.

Flooding of Exposed Contaminated Surfaces. In several cases, contaminated surfaces would be wetted by reservoir waters, leading to direct transfer of radioactive material to the river. For example, under reservoir conditions the $107-F$ reactor effluent piping would be open to water at the retention basin, outfall structure, and manholes, allowing internal contamination to be directly transferred to reservoir water. Transfer would be accelerated by drainage and refill of contaminated piping during periodic drawdowns. Criteria for identifying facilities requiring decommissioning because of potential direct transfer of contamination to the river are based on water levels projected for flood conditions with wave action (Table 7 ).

Flooding of Facilities Containing Buried Radioactive Material. Several facilities containing buried radioactive materials, including solid waste burial grounds and liquid waste disposal sites at the 100-F and $100-\mathrm{H}$ reactor areas, would be partly or wholly inundated by projected reservoir levels. The radioactive inventories of these facilities would be exposed to a saturated soil environment and subject to leaching. Containment would be provided only by shallow earth cover as little as 5 feet and generally no greater than 20 feet in depth. Particularly susceptible would be radioactive material at elevations between normal operating and drawdown levels of the reservoir where reservoir drawdown would result in rapid drainage of groundwater and concomitant transport of radioisotopes to the reservoir. Corrosion and deterioration of buried radioactive materials may be promoted by fluctuation between saturated and nonsaturated soil environments leading to accelerated leach rates. Criteria for identifying facilities susceptible to this condition are based on projected reservoir levels under conditions of flooding (Table 7). 
TABLE 7. Criteria for Decommissioning Action

Conditions

\section{Release of Radioactivity}

Flooding of exposed contaminated surfaces

Flooding of facilities containing buried radioactive materials

Wetting of buried radioactive material

Flooding of radioactive materials within structures

Release of radioactive materials by wave action

\section{Increased Susceptibility to Structural Failure}

Deterioration of structural materials

Changes in seismic response

Changes in bearing capacity
Criteria (a)

Facilities containing exposed contaminated surfaces submerged by the 570,000 cfs $(b)$ reservoir level plus $3 \mathrm{ft}$ allowance for wave action

Facilities containing buried radioactive material submerged by 570,000 cfs reservoir level

Facilities containing buried radioactive material below the 300,000 cfs groundwater level $(c)$ plus $1 \mathrm{ft}$ buffer

Facilities having spaces containing radioactive material situated below the $300,000 \mathrm{cfs}$ groundwater level

Facilities containing radioactive material situated below the $570,000 \mathrm{cfs}$ reservoir level

plus $3 \mathrm{ft}$ allowance for wave actions or facilities located within 300 lateral $\mathrm{ft}$ of $570, \overline{000} \mathrm{cfs}$ reservoir shoreline

Facilities containing wood or steel structural components situated below 300,000 cfs reservoir level, or $300,000 \mathrm{cfs}$ groundwater level

Retired $100-\mathrm{F}$ and $100-\mathrm{H}$ structures with potential for injury, significant damage or release of radioactive material if affected by seismic activity

Facilities having footings less than $1 \mathrm{ft}$ above the $300,000 \mathrm{cfs}$ groundwater level. Facilities possibly founded on poorly consolidated fill or eolian deposits subject to wetting by the $300,000 \mathrm{cfs}$ groundwater level 
TABLE 7. (contd)

Conditions

Hydrostatic uplift

\section{Interference with Future Decommissioning Activities}

Isolation

Flooding of spaces within structures

Flooding of radioactive material potentially requiring excavation

\section{Attractive Nuisances and Concealed Hazards} Near Shoreline

Attractive nuis ances

\section{Concealed hazards}

Interference with the 0peration of Facilities
Criteria

(a)

Facilities subject to hydrostatic uplift at 570,000 cfs reservoir level or 300,000 cfs groundwater level

Facilities which potentially require decommissioning isolated or flooded by the $300,000 \mathrm{cfs}$ reservoir levels

Facilities having spaces containing contaminated material with a floor elevation less than the 300,000 cfs groundwater level

Facilities containing subsurface radioactive material at less than $300,000 \mathrm{cfs}$ groundwater level

Above-grade structures located outside existing fenced exclusion areas and visible from the reservoir shoreline which present significant industrial safety hazards

Facilities outside existing fenced exclusion zones and located within one mile of the shoreline which present potential for collapse or for fugitive surface contamination

Case-by-case assessment of the effect of reservoir and groundwater levels on operation of active and standby facilities

(a) See Table 8 for corresponding reservoir and groundwater elevation.

(b) Standard project flood (regulated) for Mid-Columbia Reach. See Task 3.

(c) A $300,000 \mathrm{cfs}$ flow is expected to be maintained for a sufficient period to affect groundwater levels once every 5 to 10 years. 
Wetting of Buried Radioactive Material by Groundwater. The proposed reservoir will elevate groundwater levels sufficiently to bring the radioactive inventories of a number of liquid and solid waste disposal sites to within the zone of saturation. Because of the proximity of these facilities to the reservoir shoreline, a probability for transfer of radioactive material to the river would exist. The criteria for identifying facilities subject to this effect are based on maximum expected groundwater levels resulting from reservoir construction, plus a buffer allowance (Table 7).

Flooding of Radioactive Material Within Structures. The floor levels of several structures in the $100-\mathrm{F}$ and $100-\mathrm{H}$ Areas lie within the predicted zone of saturation under 400-foot reservoir conditions. These spaces would likely flood from seepage through joints and cracks in structural concrete and reverse flow through process and sanitary sewers. Spread of existing surface contamination throughout flooded spaces and transfer to the surrounding soil environment is likely, and eventual transfer to the river is possible. Criteria established for identifying facilities susceptible to this effect are based on maximum expected groundwater levels (Table 7).

Release of Radioactive Materials by Wave Action. Wave action could lead to exposure of radioactive materials along the reservoir shoreline by eroding cover from buried radioactive material near the shoreline or by undercutting bluffs supporting contaminated facilities or containing radioactive materials. (Saturation of underlying materials by rising groundwater levels could also lead to slumping or collapse of bluffs). Criteria established to identify susceptible facilities are based on an allowance for wave action at flood conditions and the 300-foot shoreline buffer proposed by the Corps of Engineers (Table 7).

\section{Increased Susceptibility to Structural Failure}

A rise in groundwater can increase the susceptibility of facilities to structural failure by promoting deterioration of structural materials, affecting seismic response, impairing subgrade bearing capacity, and creating hydrostatic uplift. 
Deterioration of Structural Materials. Foundations, floors, and lower walls of facilities in the $100-\mathrm{F}$ and $100-\mathrm{H}$ Areas will be exposed to continuous or periodic wetting should the proposed dam and reservoir be constructed. Potentially affected materials include concrete, wood, and steel. Concrete is not expected to be affected; however, accelerated corrosion of the steel effluent lines and decay of timber-framed cribs may occur.

Changes in Seismic Response. Potential for soil liquefaction increases with groundwater level, leading a greater probability of damage should an earthquake occur. Task 2: Soil Liquefaction Studies concluded that potential for soil liquefaction would exist in the $100-\mathrm{F}$ and $100-\mathrm{H}$ Areas if the water table is elevated as a result of dam construction and reservoir fill. Because it is not known what measures were taken during construction of the $100-F$ and $100-H$ reactor plants to prevent so $i l$ liquefaction, it is further concluded that either the soils under $100-F$ and $100-H$ structures should be examined to determine their potential for liquefaction and appropriate corrective action be taken or that structures in these areas be removed prior to reservoir fill. Because current Department of Energy decommissioning plans are to dismantle the above-ground structures in the 100-F and 100-H Areas (Department of Energy, 1978), appropriate action would be to remove the structures in these areas prior to reservoir fill. Criteria for identification of facilities subject to changes in seismic response are based on location (100-F or 100-H Areas) and potential for injury or damage should they fail (Table 7).

Changes in Bearing Capacity. Introduction of groundwater into previously unsaturated subgrade soils may reduce the bearing capacity of these soils, leading to differential settlement of buildings and pipelines and consequent structural damage and cleavage of piping and conduits. Conclusions of Task 3 regarding major structures constructed on undisturbed ground or lean concrete fill were similar to those of the Shannon and Wilson study (1966). Additional settlement from introduction of ground-water would be only a fraction of the original settlement during and following construction, providing the groundwater table rises to with in no more than 1 foot of the undersides of the foundations. Additional rise may require remedial action to prevent settlement (W. L. Shannon, 1978). It is also observed that structures founded on 
poorly consolidated backfill or eolian sands or silts may experience significant settlement if these materials are saturated by the elevated groundwater table. It is not known which structures might be underlain by such materials, but they likely would be limited to pipelines, conduits, and minor buildings. Criteria of Table 7 are based on these considerations.

Hydrostatic Uplift. Predicted groundwater levels are sufficiently high to exert hydrostatic uplift forces on several structures in the $100-F$ and 100-H Areas including retention basins, reactor buildings, and effluent lines.

Interference with Future Decommissioning Activities

Current Department of Energy planning envisions eventual decommissioning of all surplus facilities in the 100 Areas. Decommissioning activities will likely include dismantling of uncontaminated buildings, decontamination and dismantling to grade of contaminated buildings, and protective storage of solid and liquid waste disposal sites. Solid and liquid waste disposal sites containing transuranic materials may require excavation.

The proposed reservoir will create conditions interfering with facility decommissioning, particularly in the relatively low-lying $100-F$ and $100-H$ reactor areas. Conditions inimical to decommissioning activities include isolation of facilities from the "mainland," flooding of spaces within structures requiring decommissioning, and flooding of buried radioactive materials potentially requiring excavation.

Decommissioning of facilities affected by the conditions described above may best be accomplished prior to reservoir fill. Criteria for identifying potentially affected facilities given in Table 7 are based on reservoir and groundwater levels predicted to occur under normal flow conditions. Several of the facilities identified by use of these criteria will have been identified as requiring decommissioning by other criteria of Table 6; however, this redundancy serves to emphasize the need to decommission these facilities prior to filling the proposed reservoir.

Attractive Nuisances and Concealed Hazards Near Shoreline

Opening the shore near retired reactor areas to public access would be an administrative decision and would require facilities presenting significant hazard to the general public to be removed or isolated. However, even if the 
shorelines at these areas are restricted from public access, trespassing could be provoked by the presence of "attractive nuisances" and other hazards.

Attractive Nuisances. "Attractive nuisances" are structures which invite investigation by the passerby but which may have a potential for harm to the unknowledgable or unwary. Many of the retired 100 Area facilities clearly possess these characteristics and provision should be made to discourage trespassing and protect unauthorized visitors by removal, concealment, or isolation of offending facilities.

Quantitative definition of facilities likely to be attractive nuisances is difficult, and the criterion proposed in Table 7 can be invoked only through case-by-case judgment. In general, any facility visible from the shoreline presenting significant industrial safety hazard (including accessible radioactive material) is included. Many 100 Area facilities, both active and inactive, meet these criteria, of course, and dismantling is obviously not the appropriate protective action in all cases. Dismantling may be appropriate for surplus facilities near shore, while fencing may be satisfactory for those located distant from shore. Active and standby facilities are expected to be enclosed by security fencing and should not require special action.

Concealed Hazards. More insidious hazards are those presented by subsurface facilities with the potential for collapse. Identification of these facilities cannot be based on visibility or attractiveness since by their nature they are unobtrusive. Also included are liquid waste disposal sites and other facilities with potential fugitive surface contamination.

The criteria of Table 7 for identifying these facilities assume that persons exploring the shore will be on foot, requiring concealed hazards to be eliminated or isolated if within a reasonable walking distance of the shoreline.

Interference with the Operation of Facilities

Potential interference with the operation of active or standby facilities could result from increased ground or surface water levels. Susceptible facilities include river pumphouses, outfalls, and liquid waste disposal facilities. In no case would lower levels of buildings in use be exposed to flooding by 
surface waters or seepage from elevated groundwater tables. Because of the diverse nature of operating and standby facilities, consistent criteria for identification of potentially affected facilities could not be readily formulated and so these facilities were assessed on a case-by-case basis.

Projected Reservoir and Groundwater Elevations

The projected reservoir and groundwater elevations used in assessing facilities by the criteria of Table 7 are summarized in Table 8 . The groundwater elevations include a 5-foot uncertainty tolerance.

\section{SIGNIFICANT FINDINGS}

Findings of this task are discussed in this section, organized by Hanford "Areas." Topics covered include identification of facilities requiring decommissioning, proposed decommissioning actions and estimated costs, and decommissioning schedules and budgets that would accomplish the required decommissioning actions by the proposed reservoir fill date.

The section concludes with recommendations for studies required to more conclusively establish decommissioning requirements and costs resulting from the proposed dam and reservoir.

\section{$\underline{100-F \text { Area }}$}

The 100-F Area, farthest downstream and at the lowest elevation of the six reactor areas, would be most severely affected by the elevated ground and surface water levels created by the proposed reservoir. The area is situated upon a slight knoll, cresting at 416 feet at the former site of the 183-F Reservoir (Figure 9). The knoll would become an island at normal reservoir operating levels. The production reactor complex is located at 414 feet, 10 feet above the projected reservoir level of 404 feet at 570,000 cfs and 4 feet above the projected groundwater level of 410 feet at 300,000 cfs.

Facilities Requiring Decommissioning

Facilities potentially requiring decommissioning are identified in Table 9. Specific characteristics of each facility impacting upon decommissioning requirements are tabulated in the right-hand columns (see footnotes to Table 9 for explanation). Interactions between 100-F Area 
TABLE 8. Projected Reservoir and Groundwater Elevations with Ben Franklin Dam and Reservoir

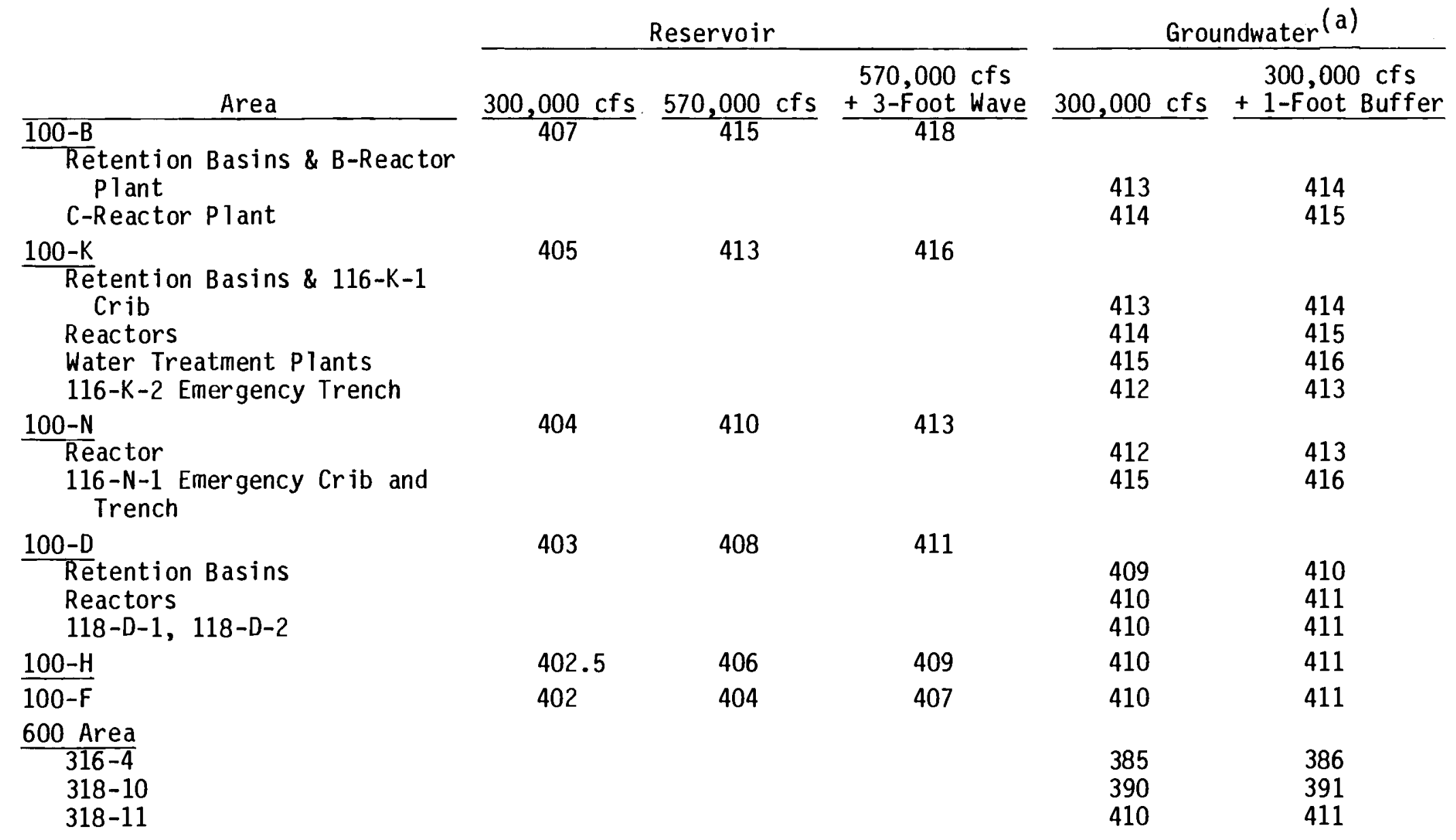

(a) Includes 5-foot uncertainty allowance over levels projected by groundwater model. 
TABLE 9. 100-F Area Facilities Potentially Requiring Decommissioning Building

$107-F$ Reterition Basin

$107-F$ Reactor Effluent Piping
105-F Production Reactor

$42,500 \mathrm{ft}^{2}$ reinforced concrete and concrete block structure housing production reactor, irradiated

metal storage basin and auxilaries. Retired, metal storage basin filled with soil.

$230^{\circ} \times 467^{\prime}$ reinforced concrete retention basin with $20^{\prime}$ walls. Contains several inches of contaminated sludge. Underlying and

adjacent soil contaminated from

past basin leakage. Retired with 3-5 ft of soil backfill.

$105-F / 107-F$ section, for transfer of reactor effluent to the retention basin. Retired, some above-ground sections dismantled.

107-F/1904-F section, for transfer of reactor effluent from the retention basin to the river outfall. Retired.

108-F Biology Laboratory

$31,000 \mathrm{ft}^{2}$ reinforced concrete and concrete block structure. Retired.

115-F Gas Recirculation Building

116-F Reactor Ventilation Exhaust Stack

116-F-1 Liquid Waste Trench $16,500 \mathrm{ft}^{2}$ reinforced concrete and concrete block structure housing reactor gas processing equipinent. Retired.

$16^{\prime}$ diameter by $200^{\prime}$ high reinforced concrete stack. Retired

$40^{\prime} \times 1500^{\prime}$ trench (Lewis Canal) used for disposal of miscellaneous liquid wastes from $105-\mathrm{F}, 190-\mathrm{F}$ and $189-\mathrm{F}$.

Serviced by a 54" RCP effluent line.

116-F-2 107 Emergency Trench

$200^{\prime} \times 550^{\prime}$ trench for disposal of reactor effluent following fuel cladding failures. Serviced by a $12^{\prime \prime}$ steel effluent line from $107-F$. Retired and backfilled.

\begin{tabular}{|c|c|c|c|c|c|c|}
\hline $\begin{array}{l}\text { Grade } \\
\mathrm{ft}(\mathrm{a})\end{array}$ & $\begin{array}{l}\text { Footing } \\
\text { ft(b) }\end{array}$ & $\begin{array}{l}\text { Floor } \\
\text { ft(c) }\end{array}$ & $\begin{array}{l}\text { Cont } \\
\text { ft(d) }\end{array}$ & $\begin{array}{l}\text { Actjojty } \\
\mathrm{c} / \mathrm{m}(\mathrm{e})\end{array}$ & $\begin{array}{c}\text { TRU } \\
\mathrm{pCi} / \mathrm{g}(\mathrm{f})\end{array}$ & $\begin{array}{l}\operatorname{Inv} \\
C_{j}(g)\end{array}$ \\
\hline 413 & 385 & 389 & Unk & -- & - & $\overline{14,500}$ \\
\hline 411 & Unk & 3909 & 384 & 40,000 & 45 & 93 \\
\hline $\begin{array}{l}413 / \\
411\end{array}$ & -- & $\begin{array}{l}402 / \\
396\end{array}$ & Unk & $\begin{array}{l}\text { Approx } \\
50,000(h)\end{array}$ & $\begin{array}{l}10- \\
300(h)\end{array}$ & Unk \\
\hline $\begin{array}{l}411 / \\
400\end{array}$ & -- & $\begin{array}{l}406 / \\
389\end{array}$ & Unk & & & \\
\hline 412.5 & 408.5 & Unk & Unk & 25,000 & Unk & Unk \\
\hline 412 & Unk & 402.5 & 402.5 & Unk & Unk & Unk \\
\hline 405 & 387.5 & 405 & 405 & Unk & Unk & Unk \\
\hline $\begin{array}{l}396 / \\
389\end{array}$ & -- & $\begin{array}{l}387 / \\
385\end{array}$ & 373 & 500 & .99 & 3.4 \\
\hline $409 /$ & -- & $389 /$ & 378 & 1000 & .55 & 15 \\
\hline
\end{tabular}

386 
TABLE 9. (contd)

116-F-3 Metal Storage Basin

116-F-4 Pluto Crib

116-F-5 Ball Washer Crib

116-F-6 1608 Trench

a

116-F-7 117 Crib

116-F-8 Dumny Decontamination Drain

116-F-9 Animal Waste Trench

117-F Confinement Filter
Building

118-F-1 Burial Ground $20^{\prime} \times 100^{\prime}$ trench used for disposal of $105-\mathrm{F}$ metal storage basin sludge. Retired and backfilled.

$10^{\prime} \times 10^{\prime}$ timber-framed crib used for disposal of water from individual process tubes following cladding fajlure. Retired.

$10^{\prime} \times 10^{\prime}$ timber-framed crib used for disposal of waste from boron steel ball decontamination. Retired.

$10^{\prime} \times 100^{\prime}$ trench used for disposal of reactor outage water. Retired and

backfilled to grade.

A crib of unknown dimensions for $117-F$. Retired, currently re-

leased fron radiological control.

A french drain (?) for disposal effluent from decontamination of fuel element spacers. Retired.

Two trenches, $20^{\circ} \times 30^{\prime}$ used for disposal of contaminated waste water from the biology laboratory animal quarters. Retired.

A most ly-underground reinf orced concrete building, 39' $\times 59^{\prime}$

formerly containing filters for reactor ventilation air exhaust. Retired, filters removed.

$500^{\prime} \times 600^{\prime}$ burial ground containing mixed wastes. Retired. covered by $2-4$ ' cobbles.

\begin{tabular}{|c|c|c|c|c|c|c|}
\hline $\begin{array}{l}\text { Grade } \\
\mathrm{ft}(\mathrm{a})\end{array}$ & $\begin{array}{l}\text { Foot ing } \\
\mathrm{ft}(\mathrm{b})\end{array}$ & $\begin{array}{l}\text { Floor } \\
\mathrm{ft}(\mathrm{c})\end{array}$ & $\begin{array}{l}\text { Cont } \\
\mathrm{ft}(\mathrm{d}) \\
\end{array}$ & $\begin{array}{l}\text { Actjivity } \\
\mathrm{c} / \mathrm{m}(\mathrm{e})\end{array}$ & $\begin{array}{c}\text { TRU } \\
\mathrm{pCi} / \mathrm{g}(\mathrm{f}) \\
\end{array}$ & $\begin{array}{l}\text { Inv } \\
\mathrm{Ci}(\mathrm{g}) \\
\end{array}$ \\
\hline 414 & - & 404 & 394 & 30 & None & .002 \\
\hline 414 & - & 404 & 390 & 6000 & 110 & 3.5 \\
\hline 410 & -- & 400 & 400 & 30 & None & $9 \times 10^{-4}$ \\
\hline $\begin{array}{l}410 / \\
414\end{array}$ & -- & $\begin{array}{l}390 / \\
394\end{array}$ & 385 & 600 & 0.76 & 6.5 \\
\hline 404 & -- & Unk & 394 & 25 & 0.1 & $1.4 \times 10^{-4}$ \\
\hline 414 & -- & Unk & 387 & 1500 & 0.87 & .12 \\
\hline 404 & -- & Unk & Unk & Unk & Unk & Unk \\
\hline 405 & Unk & 384 & 382 & 2000 & $150 \mathrm{~d} / \mathrm{m}$ & Unk \\
\hline $\begin{array}{l}393 / \\
399\end{array}$ & - & $\begin{array}{l}393 / \\
379\end{array}$ & Unk & Unk & Unk & 2200 \\
\hline
\end{tabular}




\section{TABLE 9. (contd)}

118-F-2 Burial Ground

118-F-3 Burial Ground

118-F-4 Burial Pit

118-F-5 Burial Ground

118-F-6 Burial Ground

119-F Sample House

141-C Animal Barn

1608-F Lift Station

1701-FA Small Animal Annex $325^{\prime} \times 365^{\prime}$ burial ground containing mixed wastes. Retired.

$50^{\circ} \times 175^{\prime}$ burial ground containing irradiated and contaminated wastes. Retired.

$10^{\prime} \times 15^{\prime}$ burial pit used for disposal of contaminated silica gel from $115-\mathrm{F}$. Retired.

$150^{\circ} \times 500^{\prime}$ burial ground used for disposal of contaminated litter from the animal $\mathrm{farm}$. Retired, covered by several

feet of cobbles.

$200^{\prime} \times 400^{\prime}$ burial ground used for disposal of contaminated wastes from the animal farm. Retired.

$20^{\prime} \times 14^{\prime} \mathrm{slab}$, former ly supporting a Butler building which

housed exhaust air monitoring equipment.

$5000 \mathrm{ft}^{2}$ Butler building on a concrete slab housing animal stalls and laboratory facilities. Retired.

$1300 \mathrm{ft}^{2}$ reinforced concrete building housing pumping equipment for contaminated liquids from $115-F$ and $105-F$. Retired.

$625 \mathrm{ft}^{2}$ concrete structure formerly used to house animals for the biology laboratory. Retired.

\begin{tabular}{|c|c|c|c|c|c|c|}
\hline $\begin{array}{l}\text { Grade } \\
\text { ft }(a)\end{array}$ & $\begin{array}{l}\text { Footing } \\
f t(b)\end{array}$ & $\begin{array}{l}\text { Floor } \\
\text { ft }(c)\end{array}$ & $\begin{array}{l}\text { Cont } \\
\mathrm{ft}(\mathrm{d})\end{array}$ & $\begin{array}{l}\text { Actjvity } \\
\mathrm{c} / \mathrm{m}(\mathrm{e})\end{array}$ & $\underset{\mathrm{pC} i / g(f)}{\text { TRU }}$ & $\begin{array}{l}\text { Iny. } \\
\mathrm{C}_{\mathrm{i}}(\dot{\mathrm{g}})\end{array}$ \\
\hline $\begin{array}{l}392 / \\
400\end{array}$ & -- & $\begin{array}{l}372 / \\
380\end{array}$ & Unk & Unk & Unk & 2200 \\
\hline $\begin{array}{l}401 / \\
404\end{array}$ & -- & $\begin{array}{l}386 / \\
389\end{array}$ & Unk & Unk & Unk & 2200 \\
\hline 400 & -- & 390 & Unk & Unk & Unk & Unk \\
\hline $\begin{array}{l}398 / \\
412\end{array}$ & -- & Unk & Unk & Unk & Unk & 15.3 \\
\hline 412 & - & Unk & Unk & Unk & Unk & 15 \\
\hline 405 & Unk & 405 & Unk & Unk & Unk & Unk \\
\hline 412 & Unk & 412 & Unk & 6000 & Unk & Unk \\
\hline 413 & Unk & 403 & Unk & 400 & $650 \mathrm{~d} / \mathrm{m}$ & Unk \\
\hline 414 & Unk & 414 & None & None & None & None \\
\hline
\end{tabular}


TABLE 9. (contd)

\begin{tabular}{|c|c|c|c|c|c|c|c|c|c|}
\hline & & & $\mathrm{ft}(\mathrm{a})$ & $\mathrm{ft}(\mathrm{b})$ & $\mathrm{ft}(\mathrm{c})$ & $\mathrm{ft}(\mathrm{d})$ & $\mathrm{c} / \mathrm{m}(\mathrm{e})$ & $\mathrm{pCi} / \mathrm{g}(\mathrm{f})$ & $\underline{C i}(g)$ \\
\hline $1717-F$ & Maintenance Shop & $\begin{array}{l}11,250 \mathrm{ft}^{2} \text { frame building } \\
\text { formerly housing maintenance } \\
\text { shops and currently used as } \\
\text { J. A. Jones' offices. }\end{array}$ & 412 & Unk & 412 & None & None & None & None \\
\hline $1904-F$ & Outfall & $\begin{array}{l}250 \mathrm{ft}^{2} \text { we ir box with a } 14^{\prime} \\
\text { concrete spillway and two } 42^{\prime \prime} \\
\text { steel discharge lines to mid- } \\
\text { river. Retired, covered with } \\
\text { earth. }\end{array}$ & 400 & Unk & Unk & Unk & Unk & Unk & Unk \\
\hline $\begin{array}{l}3-13-71 / \\
141-C\end{array}$ & Unplanned Release & $\begin{array}{l}20^{\prime} \times 40^{\prime} \text { Unplanned release } \\
\text { from failure of sewer between } \\
141-\mathrm{C} \text { and } 141-\mathrm{N} \text {. Covered with } \\
\text { gravel. }\end{array}$ & $\begin{array}{l}412 / \\
416\end{array}$ & -- & -- & Unk & 20,000 & Unk & 20 \\
\hline
\end{tabular}

\footnotetext{
(a) Grade: The finished grade elevation of the facility in feet above sea level. A range may be given for facilities having no single finished grade.

(b) Footing: The footing subgrade elevation of structures.
(c) Floor:

(c) Floor: The elevation of the lowest floor of structures, the original trench or crib bottom of liquid and solid waste disposal

d) Cont: facilities, and the invert of facilities comprised of piping.

作 most cases the elevations entered into Cont. are based on results of the United Nuclear Industries sampling program reported in UNI-946. Because the reported depth is based on samples, it is possible that contamination might be present at even lower levels. Because samples were, in general, taken at locations likely to represent maximum penetra-

(e) Activity: The maximum level of radioactive contamination, in counts per minute, encountered in the predicted zone of saturation,

(f) TRU: $\quad$ The maximum level of transuranic contamination, in picocuries per gram, encountered in the predicted zone of

saturation or below levels of flooding per Table 8 .

(g) Inv: The estimated total radionuclide inventory of the facility, in curies. Included is all inventory present both within and above the saturation or flooding.
} 
facilities and projected groundwater and reservoir levels are tabulated in Table 10, organized by the decommissioning criteria established earlier. These interactions are discussed in the following paragraphs.

Release of Radioactivity. Facilities which would be partly or wholly submerged by reservoir waters at the 570,000 cfs stage include the 107-F retention basin, the $107-F$ reactor effluent piping, liquid waste disposal sites $116-\mathrm{F}-1,116-\mathrm{F}-7$ and $116-\mathrm{F}-9$; burial grounds $118-\mathrm{F}-1,118-\mathrm{F}-2,118-\mathrm{F}-3$, $118-\mathrm{F}-4$, and $118-\mathrm{F}-5$; and the $1904-\mathrm{F}$ river outfall structure. Contaminated surfaces within the effluent piping would be directly exposed to reservoir waters. Retention basin sludge, contaminated to levels of $45 \mathrm{pCi} / \mathrm{g} 239 / 240 \mathrm{pu}$, is currently covered by several feet of gravelly soil. Because of its porosity this cover would provide little protection from transfer of contamination to the river. Water moving in and out of the retention basin and effluent piping during periodic reservoir drawdowns would probably accelerate the transfer of radicactivity to the river.

The radioactive inventories of the liquid waste disposal sites, burial grounds and the river outfall structure are covered by 5 to 20 feet of soil backfill, which should inhibit transfer of radicactive materials to the reservoir. However, transfer rates may still be high, given the relatively shallow cover and the potential for rapid groundwater flows induced by cycling of reservoir levels.

The radioactive inventories of several subsurface facilities not directly inundated by reservoir waters would be within the elevated zone of groundwater saturation accompanying the reservoir. These facilities include liquid waste disposal sites $116-F-2,116-F-3,116-F-4,116-F-5,116-F-6,116-F-8$, and the 3-13-71/141-C Unplanned Release.

Several structures in the 100-F Area have spaces containing contaminated surfaces or equipment that could be flooded by elevated groundwater levels. These include the $105-F$ production reactor, the $115-F$ gas recirculation building, the 117-F confinement filter, and the 1608-F lift station.

Several facilities are located such that reservoir wave action could erode soil cover leading to eventual exposure of contaminated materials. Susceptible facilities include 107-F (basin and effluent piping), liquid waste 
TABLE 10. Effects of Ben Franklin Reservoir on 100-F Area Facilities

\begin{tabular}{|c|c|c|c|c|c|}
\hline & & & Release of $R$ & dioactivity & \\
\hline & & $\begin{array}{c}\text { Flooding of Exposed } \\
\text { Contaminated Surfaces }\end{array}$ & $\begin{array}{c}\text { Flooding of } \\
\text { Facilities w/Buried } \\
\text { Radioactive Material } \\
\end{array}$ & $\begin{array}{l}\text { Wetting of Buried } \\
\text { Radioactive Material } \\
\text { by Groundwater } \\
\end{array}$ & $\begin{array}{l}\text { Flooding of Radio- } \\
\text { active Materials } \\
\text { Within Structures } \\
\end{array}$ \\
\hline & 105-F Production Reactor Building & & & & $x$ \\
\hline & 107-F Retention Basin & $x$ & $x$ & $x$ & \\
\hline & 107-F Reactor Effluent Piping & $x$ & & & $x$ \\
\hline & 108-F Biology Laboratory & & & & \\
\hline & 115-F Gas Recirculation Building & & & & $x$ \\
\hline & 116-F Reactor Ventilation Exhaust Stack & & & & \\
\hline & 116-F-1 Liquid Waste Trench & & $x$ & $x$ & \\
\hline & 116-F-2 107 Emergency Trench & & & $\mathrm{x}$ & \\
\hline & 116-F-3 Metal Storage Basin Trench & & & $x$ & \\
\hline & 116-F-4 Pluto Crib & & & $x$ & \\
\hline & 116-F-5 Ball Washer Crib & & & $x$ & \\
\hline & 116-F-6 1608 Trench & & & $x$ & \\
\hline N & $116-F-7117 \mathrm{Crib}$ & & $x$ & $x$ & \\
\hline & 116-F-8 Dummy Decontamination French Drain & & & $x$ & \\
\hline & 116-F-9 Animal Waste Trench & & $x$ & $x$ & \\
\hline & 117-F Conf inement Filter Building & & & & $x$ \\
\hline & 118-F-1 Burial Ground & & $x$ & $x$ & \\
\hline & 118-F-2 Burial Ground & & $x$ & $x$ & \\
\hline & 118-F-3 Burial Ground & & $x$ & $x$ & \\
\hline & $118-F-4115$ Burial Pit & & $x$ & $x$ & \\
\hline & 118-F-5 Sawdust Burial Ground & & $x$ & $x$ & \\
\hline & 118-F-6 Burial Ground & & & $x$ & \\
\hline & 119-F Sample House & & & & \\
\hline & 141-C An imal Barn & & & & \\
\hline & $1608-F$ Lift Station & & & & $?$ \\
\hline & 1701-FA Small An imal Annex & & & & \\
\hline & 1904-F Outfal1 & & $x$ & $x$ & \\
\hline & 3-13-71/141-C Unplanned Release & & & $x$ & \\
\hline
\end{tabular}


TABLE 10. (contd)

\begin{tabular}{|c|c|c|c|c|c|}
\hline $\begin{array}{l}\text { Release of } \\
\text { Radioactivity }\end{array}$ & & Stru & $\mathrm{ral}$ & & Decommissioning \\
\hline $\begin{array}{l}\text { Release of Radio- } \\
\text { active Materials } \\
\text { by Wave Action }\end{array}$ & $\begin{array}{l}\text { Deterioration } \\
\text { of Structural } \\
\text { Material }\end{array}$ & $\begin{array}{l}\text { Changes in } \\
\text { Seismic } \\
\text { Response }\end{array}$ & $\begin{array}{l}\text { Changes in } \\
\text { Bearing } \\
\text { Capacity }\end{array}$ & $\begin{array}{l}\text { Hydrostatic } \\
\text { Uplift }\end{array}$ & $\begin{array}{c}\text { Isolation of } \\
\text { Facility }\end{array}$ \\
\hline
\end{tabular}

103-F Metal Storage Building

Materials
Wave Action

Materia

Uplift

Facility

105-F Production Reactor Building

107-F Retention Basin

107-F Reactor Effluent Piping

108-F Biology Laboratory

115-F Gas Recirculation Building

116-F Reactor Ventilation Exhaust Stack

115-F-1 Liquid Waste Trench

116-F-2 107 Emergency Trench

116-F-3 Metal Storage Basin Trench

116-F-4 Pluto Crib

116-F-5 Ball Washer Crib

$116-F-61608$ Trench

$116-\mathrm{F}-7117 \mathrm{Crib}$

116-F-8 Dummy Decontamination French Drain

116-F-9 Animal Waste Trench

117-F Confinement $F i l t e r$ Building

118-F-1 Burial Ground

118-F-2 Burial Ground

118-F-3 Burial Ground

118-F-4 115 Burial Pit

118-F-5 Sawdust Burial Ground

118-F-6 Burial Ground

119-F Sample House

141-C Animal Barn

1608-F Lift Station

1701-FA Small Animal Annex

1904-F Outfall

3-13-71/141-C Unplanned Release $x$

$x$
$x$
$x$
$x$
$x$
$x$

$x$

$x$

$x$

$x$

$x$

$x$

$x$

$x$

$x$

$x$

$x \quad x$

$x$

$x$

$x$

$x$

$x$

$x$

$x$

$x$

$x$

$x$

$x$

$x \quad x$

$x$

$?$

$x$ 
TABLE 10. (contd)

\begin{tabular}{|c|c|c|c|c|}
\hline \multicolumn{2}{|c|}{ Decommissioning } & \multicolumn{2}{|c|}{ Hazard } & Operation \\
\hline $\begin{array}{l}\text { Flooding of } \\
\text { Spaces With- } \\
\text { in Structures }\end{array}$ & $\begin{array}{l}\text { Flooding of Radioactive } \\
\text { Material Potentially } \\
\text { Requiring Excavation }\end{array}$ & $\begin{array}{l}\text { Attractive } \\
\text { Nuisance }\end{array}$ & $\begin{array}{c}\text { Concealed } \\
\text { Hazards }\end{array}$ & $\begin{array}{l}\text { Interference } \\
\text { with Operation }\end{array}$ \\
\hline
\end{tabular}

103-F Metal Storage Building

105-F Production Reactor Building

107-F Retention Basin

107-F Reactor Effluent Piping

108-F Biology Laboratory

115-F Gas Recirculation Building

116-F Reactor Ventilation Exhaust Stack

115-F-1 Liquid Waste Trench

116-F-2 107 Emergency Trench

116-F-3 Metal Storage Basin Trench

116-F-4 Pluto $\mathrm{Cr}$ ib

$116-\mathrm{F}-5$ Ball Washer Crib

116-F-6 1608 Trench

116-F-7 117 Crib

116-F-8 Durmy Decontamination French Drain

116-F-9 Animal Waste Trench

117-F Confinement $F i l$ ter Building

118-F-1 Burial Ground

118-F-2 Burial Ground

118-F-3 Burial Ground

118-F-4 115 Burial Pit

118-F-5 Sawdust Burial Ground

118-F-6 Burial Ground

119-F Sample House

141-C Animal Barn

1608-F Lift Station

1701-FA Small Animal Annex

1904-F Outfall

3-13-71/141-C Unplanned Release

\begin{tabular}{|c|c|c|}
\hline \multicolumn{3}{|c|}{$x$} \\
\hline$x$ & & $x$ \\
\hline$x$ & . & $x$ \\
\hline \multicolumn{3}{|c|}{$x$} \\
\hline & & $x$ \\
\hline & & $x$ \\
\hline & & $x$ \\
\hline$x$ & & $x$ \\
\hline$x$ & & $x$ \\
\hline & & $x$ \\
\hline$x$ & & $x$ \\
\hline \multirow[t]{8}{*}{$x$} & & $x$ \\
\hline & & $x$ \\
\hline & & $x$ \\
\hline & . & $x$ \\
\hline & & $x$ \\
\hline & & $x$ \\
\hline & & $x$ \\
\hline & & $x$ \\
\hline
\end{tabular}

$x$

$x$

$x$

$x$

$x$

$x$

$x$

$x$

$x$

$x$

$x$

$x$

$x$

$x$

$x$

$x$

$x$

$x$

$x$

$x$

$x$

$x$

$?$ $x$

$x$

1 
disposal sites $116-F-1,116-F-2,116-F-4,116-F-5,116-F-7$ and $116-F-9$, burial sites $118-F-1,118-F-2,118-F-3,118-F-4,118-F-5$ and $118-F-6$, and the 1904-F outfall.

Increased Susceptibility to Structural Failure. Accelerated corrosion of the 42-inch steel reactor effluent line could be expected under reservoir conditions, resulting in eventual collapse. Decay of the timber framing of cribs 116-F-4 and 116-F-5 (and 116-F-7, if timber-framed), followed by col1 apse, may also be accelerated.

The effect of elevated groundwater tables on the seismic response of 100-F Area facilities is not not thoroughly understood; however, it is thought that a potential for soil liquefaction under seismic stress may exist (Task 2). Structures thought to be potentially vulnerable to seismic events include $105-F$, he 108-F biology laboratory, $115-F$, the $116-F$ exhaust stack and wooden-framed cribs $116-F-4,116-F-5$, and $116-F-7$.

Facilities 105-F, 107-F (basin and piping), 108-F, 115-F, 116-F, 117-F and possibly 1608-F are founded on soil that would be saturated by the proposed reservoir, leading to potential reduction in bearing capacity and differential settiement.

Wave damage could be expected at 107-F (basin and piping), 115-F, 116-F, and $117-\mathrm{F}$.

Facilities 105-F, 107-F (basin and piping), 115-F, 117-F and possibly $1608-F$ could be affected by hydrostatic uplift. Although the metal storage basin of $105-F$ is currently filled with soil, other spaces within the building are below predicted groundwater levels. The 54-inch reinforced concrete pipe effluent line discharging to $116-F-1$ from $105-F$ may also be subject to up 7 ift.

Interference with Future Decommissioning Activities. A11 100-F facilities not flooded by reservoir waters would be isolated from the "mainland" at normal reservoir operating levels, complicating future decommissioning activities. Ground and surface water levels would flood spaces within the 107-F 
retention basin, 105-F, 115-F and 117-F buildings, and possibly 108-F and 1608-F. Also flooded would be spaces within the 116-F-4, 116-F-5, 116-F-7, and 116-F-8 liquid waste disposal sites. Buried radioactive materials would be submerged by reservoir waters $(300,000 \mathrm{cfs}$ ) at $107-\mathrm{F}$ (basin and piping), $116-F-1,118-F-1,118-F-2,118-F-3,118-F-4,118-F-5$ and 1904-F. The 300,000 cfs groundwater level would saturate buried radioactive materials at $116-F-2$, $116-F-3,116-F-4,116-F-5,116-F-6,116-F-7,116-F-8,116-F-9,118-F-6$, and 3-13-71/141-C, inhibiting future cleanup activities.

Attractive Nuisances and Concealed Hazards. A11 100-F above ground structures would be visible and readily accessible from the shoreline. Facilities presenting potential hazards to unauthorized visitors because of design, condition, radioactive contamination or other characteristics include 105-F, $107-F$ (basin and piping), 108-F, 115-F, 116-F, 117-F, 141-C animal barn, and 1608-F. Subsurface facilities within 1-mile of the projected shoreline presenting significant hazard because of voids or potential for collapse include 107-F effluent piping, 116-F-1 (54-inch effluent line), 116-F-4, $116-F-5,116-F-7$, and $116-F-8$. Fugitive surface contamination may be present at the burial sites, liquid waste trenches, 3-13-71/141-C and the 1904-F outfall.

Interference with Operation. With the exception of 1717-F, currently used by $\mathrm{J}$. A. Jones construction forces, all 100-F facilities are in a retired status and have been declared surplus.

Decommissioning Activities and Estimated Costs

Proposed decommissioning activities and estimated costs for 100-F Area facilities affected by the proposed reservoir are summarized in Table 11. Costs are in 1979 dollars and are largely based on estimates prepared for the Hanford Decommissioning Planning project. Estimated costs include packaging of radioactive materials, transport to 200 West Area and 200 West burial ground interment. Comments on specific facilities follow.

The Production Reactor and Ancillaries. Complete dismantling of the production reactor complex including 105-F, 115-F, 116-F, 117-F, 119-F, 


\section{TABLE 11. Decommissioning Activities and Estimated Costs - 100-F Area}

Facility

105-F Production Reactor
Building
$107-F$ Retention Basin
107-F Reactor Effluent
Piping

108-F Biology Laboratory

115-F Gas Recirculation Building

116-F Reactor Ventilation Exhaust Stack

116-F-1 Liquid Waste Trench (Lew is Canal)
116-F-2 107 Emergency Trench
116-F-3 Metal Storage Basin Trench

116-F-4 Pluto Crib

116-F-5 Ball Washer Crib

116-F-6 1608 Trench

116-F-7 117 Crib

116-F-8 Dummy/Perf French Drain

116-F-9 Animal Waste Trench
Decommissioning Activities

Estimated Cost (1979 \$)

$$
\text { Dismant le }
$$

$19,000,000$

Dismantle, remove underlying and adjacent contaminated soil exceeding release limits.

Remove all large diameter sections between 105-F, $107-F$ and 1904-F.

$$
\begin{aligned}
& \text { Dismantle } \\
& \text { Dismantle } \\
& \text { Dismantle }
\end{aligned}
$$

$3,300,000$

$1,100,000$

500,000

$1,300,000$

165,000

Remove contaminated soil exceeding release limits. Remove 54" effluent line.

Remove contaminated soil exceeding release limits. Remove 12 " effluent line.

Remove contaminated soil exceeding release limits. Remove effluent line.

Remove contaminated soil exceeding release limits, backfill void. Remove effluent line.

Remove contaminated soil exceeding release limits, backfill void. Remove effluent line.

Remove contaminated soil exceeding release limits. Remove effluent line.

Remove contaminated soil exceeding release limits. Remove effluent line.

Remove contaminated soil and structures exceeding release limits. Remove effluent line.

$3,100,000$

$2,400,000$

180,000

45,000

45,000

$1,400,000$

9,000

9,000

Remove contaminated soil exceeding release limits. Remove effluent line.
720,000 
TABLE 11. (contd)

Facility Decommissioning Activities

Estimated Cost (1979\$)

117-F Confinement Dismantle

230,000 Filter Building

118-F-1 Burial Ground

118-F-2 Burial Ground

118-F-3 Burial Ground

118-F-4 115 Burial Pit

118-F-5 Sawdust Burial Ground

118-F-6 Burial Ground

119-F Sample House

141-C Animal Barn

1608-F Lift Station

1701-FA Small Animal Annex

1717-F Maintenance Shop

1904-F Outfall

3-13-71/141-C Unplanned Release
Exhume buried radioactive material exceeding $\quad 16,000,000$ release limits.

Exhume buried radioactive material exceeding $5,100,000$

Exhume buried radioactive material exceeding release limits.

Exhume buried radioactive material exceeding release limits.

Exhume buried radioactive material exceeding release limits.

Exhume buried radioactive material exceeding release limits.

Remove remaining slab.

$$
\begin{aligned}
& \text { Dismantle } \\
& \text { Dismant le } \\
& \text { Dismantle }
\end{aligned}
$$$$
\text { Dismant le }
$$

limits, backfill, decontaminate we irbox to release $107-F$ Reactor Effluent Piping.

Remove contaminated soil exceeding release 1 imits. Remove 8" sewer between $141-\mathrm{C}, 14 \mathrm{I}-\mathrm{F}$ and $141-\mathrm{N}$.

$$
\text { Tota1, 100-F }
$$$$
65,000
$$$$
20,000
$$

$1,000,000$

3,000

$4,100,000$

$4,100,000$

Negligible

300,000

250,000

2,000

110,000

$65,000,000$ 
and $1608-F$ is proposed. This is in accordance with the current DOE decommissioning planning. Cost estimates are based on those compiled for the D-Reactor plant by Vitro Engineering.

Retention Basin System. Complete dismantling of the $107-\mathrm{F}$ reactor effluent piping and the 107-F retention basin is proposed. Underlying and adjacent to the retention basin is a large volume of contaminated soil; all soil exceeding release criteria(a) would be removed. The existing earth cover would be removed from 1904-F, contaminated concrete decontaminated or removed and the remaining structure reburied. River outfall piping would be left in place unless surveys determine it to be contaminated to unacceptable levels. Cost estimates are based on those compiled for the 100-D retention basin system by Vitro, scaled to the 100-F Area facilities. Removal of the 100-F retention basin system is not contemplated in current DOE decommissioning planning; however, it would appear to be necessary were a reservoir to be constructed.

Animal Farm. Dismantling of the remaining animal farm and biology research facilities (108-F, 141-C, and 1701-FA, is proposed in accordance with current DOE decommissioning planning. Costs for 108-F and $141-C$ are based on estimates by United Nuclear Industries. Removal of the 8-inch contaminated sewer between $141-\mathrm{C}, 141-\mathrm{F}$ and $141-\mathrm{N}$ is included in estimates for 3-13-71/141-C.

(a) "Release criteria" are allowable residual concentrations of specific radioisotopes following decommissioning of a facility. Allowable residual concentrations depend upon the level of control to be maintained at the site (which may range from unrestricted release to various levels of access and use control), upon the environmental conditions expected to prevail at the site and upon containment and stabilization techniques applied to the facility. Thus, release criteria will be facilityspecific. One approach currently being investigated at PNL would base release criteria on dose to the maximum exposed individual as determined by assessment of isotopic leaching rates and subsequent transport along environmental pathways. Because acceptable methods for establishing decommissioning release criteria have not yet been identified by the Federal government, it is not possible to estimate for this report volumes of contaminated soil requiring removal at the liquid and solid waste disposal sites affected by the proposed reservoir. All estimates are based on removal of all soil and materials having measurable contamination, and are presumably conservative. 
Liquid Waste Disposal Sites. All liquid waste disposal sites in the 100-F Area will be either submerged by the reservoir or wetted by elevated groundwater. Excavation of contaminated soil exceeding release criteria would be required for all facilities, including 116-F-1, 116-F-2, 116-F-3, 116-F-4, $116-F-5,116-F-6,116-F-7,116-F-8,116-F-9$, and unplanned release 3-31-71/141-C.

Removal of the effluent discharge lines is recommended for all facilities because of the difficulty of sampling pipe internals, the possible presence of high activity crud traps, and the relatively low estimated cost of pipe removal. Voids are present in cribs 116-F-4, 116-F-5, 116-F-7, and 116-F-8, which should be backfilled in any case to prevent collapse. Cost estimates for decommissioning liquid waste disposal sites are based on predictions of a dismantling cost estimating model developed for the Hanford Decommissioning Planned Project and could vary significantly depending upon release criteria.

Solid Waste Disposal Sites. All but one burial site will be partly or wholly flooded by reservoir waters. The inventory of the remaining site, 118-F-6, will be within the saturated groundwater zone. All burial sites will thus be subject to leaching and transport of radioactive materials to reservoir waters, and susceptible to erosion of cover by wave action. Excavation of interred wastes and surrounding soil exceeding release criteria would be required for all 100-F burial sites. Unlike the liquid waste disposal sites, the burial sites have not been sampled to determine the extent and nature of radioactive contamination. Cost estimates for removal of $100-\mathrm{F}$ burial sites are based on the cost model developed for the Hanford Decommissioning Planning Project and could vary significantly depending upon release criteria.

Miscellaneous Facilities. It is assumed that remaining 100-F facilities, including the 1717-F building, roads, rail lines, and utilities, would be removed following completion of the site decommissioning effort. Costs for dismantling utilities, roads, and rail lines have not been determined but are felt to be small in comparison to other 100-F Area decommissioning costs.

\section{$\underline{100-H \text { Area }}$}

The 100-H Area, situated upstream of 100-F and at a slightly higher elevation, would also be significantly affected by elevated ground and surface water levels, although not to the extent as 100-F. 100-H is situated on a low 
ridge trending NW-SE with an elevation at approximately 422 feet at the $105-\mathrm{F}$ production reactor. Swales paralleling the ridge on the northeast and southwest would flood upon fill of the proposed reservoir, creating a peninsula of the ridge (Figure 8 ).

The ridge crest at 100-H will be approximately 16 feet above the 406 -feet reservoir level at 570,000 cfs and approximately 12 feet above projected ground water levels of 410 feet at 300,000 cfs.

Facilities Requiring Decommissioning

Facilities potentially requiring decommissioning are identified in Table 12. Interactions between the 100- $\mathrm{H}$ facilities and projected groundwater and reservoir levels are indicated in Table 13. These are discussed below.

Release of Radioactivity. Facilities that would be partly or wholly submerged by reservoir waters at the $570,000 \mathrm{cfs}$ stage include the 107-H retention basin, portions of the $107-\mathrm{H}$ reactor effluent piping, the $115-\mathrm{H}-1$ burial ground, and the 1904-H outfall. Contaminated surfaces within the effluent piping would be directly exposed to reservoir waters. The retention basin sludge, contaminated to levels of $200 \mathrm{pCi} / \mathrm{g} 239 / 240 \mathrm{p}_{\mathrm{u}}$, is currently covered by 3 to 5 feet of gravelly soil, which is believed would provide little protection from transfer of radioactive materials to reservoir waters, augmented by cyclic flow of water as reservoir level fluctuated during operation.

Facilities, in addition to those directly submerged, whose radioactive inventories would be within the saturated zone include liquid waste disposal sites $116-\mathrm{H}-1,116-\mathrm{H}-2$, and $116-\mathrm{H}-3$, and burial grounds $118-\mathrm{H}-2$ and $118-\mathrm{H}-3$. There is no indication of residual radioactivity within the $107-\mathrm{H}$ sludge disposal trench; this site has been released from control. Introduction of groundwater into the radioactive inventories of these facilities may result in leaching and transport of radioactive materials to the river. Because of the proximity of these facilities to the shoreline, cyclical groundwater flows may be induced by normal fluctuations of reservoir level, augmenting release rates.

Structures in the 100-H Area having spaces containing contaminated surfaces or equipment that may be flooded by elevated groundwater levels include $105-\mathrm{H}$ and $117-\mathrm{F}$, and possibly 1608-H. 


\section{TABLE 12. 100-H Facilities Potentially Requiring Decommissioning}

105-H Production Reactor

107-H Retention Basin

107 H Reactor Effluent Piping

107-H Sludge Disposal Trench

110-H Gas Storage

$116-\mathrm{H}$ Reactor Ventilation Exhaust Stack

116-H-1 107 Emergency Trench

116-H-2 1608 Trench
105-H/107-H section, for transfer of reactor effluent to the retention basin. Retired.

107-H/1904-H section, for transfer of reactor effluent from the retention basin to the river outfall. Retired.

$62,000 \mathrm{ft}^{2}$ reinforced concrete and concrete block structure housing a production reactor, metal storage basin, and ancillaries. Retired,

$273^{\prime} \times 600^{\prime}$ reinforced concrete retention basin with $20^{\circ}$ walls. Contains several inches of contaminated sludge. Under lying and adjacent soil contaminated rom past basin leakage. Retired, with $3-5 \mathrm{ft}$ of soil backfill.

$60^{\prime} \times 300^{\prime}$ trench for disposal of sludge from 107-H. Retired.

Cylinders for storage of inert gas used for purge of the reactor core. Retired.

$200^{\prime}$ high reinforced concrete stack. Retired.

$75^{\prime} \times 100^{\prime}$ trench for disposal of reactor effluent following fuel cladding failures. Serviced by a 20 in. steel effluent line from 107-H. Retired and backfilled.

$40^{\prime} \times 150^{\prime}$ trench for disposal of reactor outage water. Retired and reactor outag illed.

$$
\frac{\begin{array}{l}
\text { Grade } \\
\mathrm{ft}(\mathrm{a})
\end{array}}{422} \frac{\begin{array}{c}
\text { Footing } \\
\mathrm{ft}(\mathrm{b})
\end{array}}{\text { Unk }} \frac{\begin{array}{c}
\text { Floor } \\
\mathrm{ft}(\mathrm{c})
\end{array}}{397} \frac{\begin{array}{c}
\text { Cont } \\
\mathrm{ft}(\mathrm{d})
\end{array}}{\text { Unk }} \frac{\begin{array}{c}
\text { Actiyity } \\
\mathrm{C} / \mathrm{m}(\mathrm{e})
\end{array}}{\text { Unk }} \frac{\begin{array}{c}
\text { TRU } \\
\mathrm{Pci} / \mathrm{g}(\mathrm{f})
\end{array}}{\text { Unk }} \frac{\begin{array}{c}
\mathrm{Inv} \\
\mathrm{Ci}(\mathrm{g})
\end{array}}{14,300}
$$

Unk

396

388.5

$40,000 \quad 200$

$\begin{array}{lllllll}422 / & -- & 414 / & 394 & \begin{array}{c}10 \mathrm{MR/} \\ \mathrm{Hr}\end{array} & 230 & \text { Unk } \\ 416 & & 406 & & & & \\ 416 / & -- & 396 & \text { Unk } & \text { Unk } & \text { Unk } & \text { Unk } \\ 412 & & & & & & \end{array}$

414 -- Unk $\quad$ Released

420 Unk -- None None None None

$423 \quad 405.5 \quad 423 \quad 423 \quad$ Unk $\quad$ Unk Unk 
TABLE 12. (contd)

116-H-3 Dummy Decontamination Drain

117-H Confinement $\mathrm{F} i l$ ter

118-H-1 Burial Ground

118- H-2 Burial Ground

116- $\mathrm{H}-3$ Burial Ground

118-H-5 Burial Trench

118-H-4 Burial Trench

119-H Sample House

151-H Primary Substation

183-H Solar Still

190-HA Pumphouse Annex

1608-H Lift Station
A french drain for disposal of effluent from decontamination of fuel spacers.

Retired.

A mostly-underground reinforced concrete building, $39^{\prime} \times 59^{\prime}$, formerly containing filters for reactor ventilation exhaust. Retired, filters removed.

$350^{\prime} \times 700^{\prime}$ burial ground containing mixed wastes. Retired, covered with $2^{\prime}-3^{\prime}$ of cobbles

$50^{\prime} \times 140^{\prime}$ burial ground containing irradiated and contaminated wastes. Retired, with $2^{\prime}-3^{\prime}$ of gravel cover.

$200^{\prime} \times 300^{\prime}$ burial ground containing contaminated and activated wastes.

Retired.

$2^{\prime} \times 30^{\prime}$ burial trench containing an irradiated thimble assembly. Retired.

$30^{\prime} \times 150^{\prime}$ burial trench containing contaminated and activated wastes.

Retired, with 2'-3' gravel cover.

$20^{\prime} \times 14^{\prime}$ concrete slab formerly supporting a Butler building which housed exhaust air monitoring equipment.

Primary substation for 100-H Area.

$315^{\prime} \times 300^{\prime}$ reinforced concrete filter plant converted to a solar still for disposal of radioactive liquids. In use.

$15,600 \mathrm{ft}^{2}$ high-bay steel frame and transite structure.

$1600 \mathrm{ft}^{2}$ reinforced concrete structure housing pumping equipment for contaminated liquids from $105-\mathrm{H}$.

\begin{tabular}{|c|c|c|c|c|c|c|}
\hline $\begin{array}{l}\text { Grade } \\
\mathrm{ft}(\mathrm{a})\end{array}$ & $\begin{array}{c}\text { Footing } \\
\text { ft }(b)^{p}\end{array}$ & $\begin{array}{l}\mathrm{Floor} \\
\mathrm{ft}(\mathrm{c})\end{array}$ & $\begin{array}{l}\text { Cont } \\
\text { ft }(d) \\
\end{array}$ & $\begin{array}{c}\text { Actiyity } \\
\mathrm{c} / \mathrm{m}(\mathrm{e})\end{array}$ & $\begin{array}{c}T R U \\
\mathrm{Pci} / \mathrm{g}(\mathrm{f}) \\
\end{array}$ & $\begin{array}{l}\operatorname{Inv} \\
\mathrm{Ci}(\mathrm{g})\end{array}$ \\
\hline 421 & -- & Unk & 406 & 60 & .27 & .07 \\
\hline 422 & Unk & 401 & 399 & 2,000 & $150 \mathrm{~d} / \mathrm{m}$ & Unk \\
\hline $\begin{array}{l}394 / \\
412\end{array}$ & -- & $\begin{array}{l}374 / \\
392\end{array}$ & Unk & Unk & Unk & 4,000 \\
\hline $\begin{array}{l}408 / \\
410\end{array}$ & - & $\begin{array}{l}392 / \\
395\end{array}$ & Unk & Unk & Unk & 300 \\
\hline 418 & -- & 395 & Unk & Unk & Unk & Unk \\
\hline 420 & -- & 415 & Unk & Unk & Unk & $<1$ \\
\hline 422 & -- & 412 & Unk & Unk & Unk & Unk \\
\hline 423 & Unk & 423 & Unk & Unk & Unk & Unk \\
\hline $\begin{array}{l}412 \prime \\
415\end{array}$ & -- & - & None & None & None & None \\
\hline $\begin{array}{l}416 / \\
419\end{array}$ & Unk & 430 & Unk & Unk & Unk & Unk \\
\hline 421 & Unk & 421 & None & None & None & None \\
\hline 422 & Unk & Unk & Unk & 4,000 & $20 \mathrm{~d} / \mathrm{m}$ & Unk \\
\hline
\end{tabular}


TABLE 12. (contd)

1713-H Warehouse

1717-H Maintenance Shop

1720-HA Munitions Storage

1904-H Outfall
$16,000 \mathrm{ft}^{2}$ steel frame and transite building.

$21,000 \mathrm{ft}^{2}$ steel frame and transite building. Retired.

$400 \mathrm{ft}^{2}$ weir box discharging to a con-

crete spillway and steel discharge lines

\begin{tabular}{|c|c|c|c|c|c|c|}
\hline $\begin{array}{l}\text { Grade } \\
\mathrm{ft}(\mathrm{a})\end{array}$ & $\begin{array}{l}\text { Footing } \\
\mathrm{ft}(\mathrm{b}) \\
\end{array}$ & $\begin{array}{l}\text { Floor } \\
\mathrm{ft}(\mathrm{c})\end{array}$ & $\begin{array}{l}\text { Cont. } \\
\mathrm{ft}(\mathrm{d})\end{array}$ & $\begin{array}{l}\text { Activity } \\
\mathrm{c} / \mathrm{m}(\mathrm{e})\end{array}$ & $\begin{array}{c}\text { TRU } \\
\mathrm{Pci} / \mathrm{g}(f) \\
\end{array}$ & $\begin{array}{l}\text { Inv. } \\
\mathrm{Ci}(g)\end{array}$ \\
\hline $\begin{array}{l}412 / \\
417\end{array}$ & Unk & 417.5 & None & None & None & None \\
\hline 421 & Unk & 422 & None & None & None & None \\
\hline 415 & Unk & Unk & None & None & None & None \\
\hline 412 & Unk & 396 & Unk & Unk & Unk & Unk \\
\hline
\end{tabular}

\footnotetext{
(a) Grade: The finished grade elevation of the facility in feet above sea level. A range may be given for facilities having no single finished grade.

(b) Footing The footing subgrade elevation of structures.

(c) Floor: The elevation of the lowest floor of structures, the original trench or crib bottom of liquid and solid waste disposal facilities, and the invert of facilities comprised of piping.

(d) Cont: The lowest depth to which radioactive contamination is known to extend for a facility, in feet above sea level. In most cases the elevations entered into Cont. are based on results of the United Nuclear Industries sampling program reported in UNI-946. Because the reported depth is based on samples, it is possible that contamination might be present at even lower levels. Because samples were, in general, taken at locations likely to represent maximum penetra$t i o n$ of contamination, these figures are probably fairly representative of the maximum penetration of contamination.

(e) Activity: The maximum level of radioactive contamination, in counts per minute, encountered in the predicted zone of saturation, or below levels of flooding.

(f) TRU: The maximum level of transuranic contamination, in picocuries per gram, encountered in the predicted zone of saturation or below levels of flooding.

(g) Inv: The estimated total radionuclide inventory of the facility, in curies. Included is all inventory present both within and above the zone of saturation or flooding.
} 


\section{TABLE 13. Effects of Ben Franklin Reservoir on 100-H Area Facilities}

\begin{tabular}{|c|c|c|c|c|}
\hline & & Release o & f Radioactivity & \\
\hline & $\begin{array}{l}\text { Flooding of Exposed } \\
\text { Contaminated Surfaces } \\
\end{array}$ & $\begin{array}{c}\text { Flooding of } \\
\text { Facilities w/Buried } \\
\text { Radioactive Material } \\
\end{array}$ & $\begin{array}{l}\text { Wetting of Buried } \\
\text { Radioactive Material } \\
\text { by Groundwater } \\
\end{array}$ & $\begin{array}{l}\text { Flooding of Radio- } \\
\text { active Materials } \\
\text { Within Structures } \\
\end{array}$ \\
\hline 105-H Production Reactor & & & & $x$ \\
\hline 107-H Retention Basin & & $x$ & $x$ & $x$ \\
\hline 107-H Sludge Disposal Trench & & & & \\
\hline 107-H Reactor Effluent Piping & $x$ & & & $x$ \\
\hline $110-H$ Gas Storage & & & & \\
\hline $\begin{array}{l}\text { 116-H Reactor Ventilation Exhaust } \\
\text { Stack }\end{array}$ & & & & \\
\hline 116-H-1 107-H Emergency Trench & & & $x$ & \\
\hline $116-\mathrm{H}-2$ 1608-H Crib and Trench & & & $x$ & \\
\hline $\begin{array}{l}\text { 116-H-3 Dummy Decontamination } \\
\text { French Drain }\end{array}$ & & & $x$ & \\
\hline 117-H Conf inement Filter Building & & & & $x$ \\
\hline 118-H-1 Burial Ground & & & $x$ & $x$ \\
\hline 118-H-2 Burial Ground & & & $x$ & \\
\hline 118-H-3 Burial Ground & & & $x$ & \\
\hline 118-H-4 Burial Trench & & & & \\
\hline 118-H-5 Burial Trench & & & & \\
\hline 119-H Sample Building & & & & \\
\hline $115-H$ Substation & & & & \\
\hline 183-H Solar Still & & & & \\
\hline 190-HA Pumphouse Annex & & & & \\
\hline 1608-H Lift Station & & & & ? \\
\hline 1713-H Warehouse & & & & \\
\hline 1717-H Maintenance Shop & & & & \\
\hline 1720-HA Munitions Storage & & & & \\
\hline 1904-H Outfall & & $x$ & & \\
\hline
\end{tabular}


TABLE 13. (contd)

\begin{tabular}{|c|c|c|c|c|c|}
\hline $\begin{array}{l}\text { Release of } \\
\text { Radioactivity }\end{array}$ & & Struct & ral Failure & & Decommissioning \\
\hline $\begin{array}{l}\text { Release of Radio- } \\
\text { active Materials } \\
\text { by Wave Action }\end{array}$ & $\begin{array}{l}\text { Deterioration } \\
\text { of Structural } \\
\text { Material }\end{array}$ & $\begin{array}{c}\text { Changes in } \\
\text { Seismic } \\
\text { Response }\end{array}$ & $\begin{array}{l}\text { Changes in } \\
\text { Bearing } \\
\text { Capacity }\end{array}$ & $\begin{array}{c}\text { Hydrostatic } \\
\text { Upl ift }\end{array}$ & $\begin{array}{c}\text { Isolation of } \\
\text { Facility }\end{array}$ \\
\hline & & $x$ & $x$ & $x$ & \\
\hline$x$ & & & $x$ & $x$ & \\
\hline$x$ & $x$ & $x$ & $x$ & $x$ & \\
\hline & & $x$ & $x$ & & \\
\hline$x$ & & & & & \\
\hline & $?$ & $?$ & & & \\
\hline & & & $x$ & $x$ & \\
\hline$x$ & & & & & \\
\hline & & & ? & $?$ & \\
\hline$x$ & & & & & \\
\hline
\end{tabular}

105-H Production Reactor

107-H Retention Basin

107-H Sludge Disposal Trench

107-H Reactor Effluent Piping

110-H Gas Storage

116-H Reactor Ventilation Exhaust Stack

116-H-1 107-H Emergency Trench

116-H-2 1608-H Crib and Trench

116-H-3 Dummy Decontamination French Dra in

117-H Confinement Filter Building

118-H-1 Burial Ground

118-H-2 Burial Ground

118-H-3 Burial Ground

118-H-4 Burial Trench

118-H-5 Burial Trench

119-H Sample Building

115-H Substation

183-H Solar Still

190-HA Pumphouse Annex

1608-H Lift Station

1713-H Warehouse

1717-H Maintenance Shop

1720-HA Munitions Storage

1904-H Outfall 
TABLE 13. (contd)

\begin{tabular}{|c|c|c|c|c|}
\hline \multicolumn{2}{|c|}{ Decommissioning } & \multicolumn{2}{|l|}{ Hazard } & Operation \\
\hline $\begin{array}{l}\text { Flooding of } \\
\text { Spaces With- } \\
\text { in Structures }\end{array}$ & $\begin{array}{l}\text { Flooding of Radioactive } \\
\text { Material Potentially } \\
\text { Requiring Excavation }\end{array}$ & $\begin{array}{l}\text { Attractive } \\
\text { Nuisances }\end{array}$ & $\begin{array}{c}\text { Concealed } \\
\text { Hazardss }\end{array}$ & $\begin{array}{c}\text { Interference } \\
\text { with Operation }\end{array}$ \\
\hline$x$ & & $x$ & & \\
\hline$x$ & $x$ & $x$ & & \\
\hline$x$ & $x$ & & $x$ & \\
\hline & & $x$ & & \\
\hline & $x$ & & $x$ & \\
\hline$?$ & $x$ & & $x$ & \\
\hline$?$ & $x$ & & $x$ & \\
\hline$x$ & & $x$ & & \\
\hline & $x$ & & $x$ & \\
\hline & $x$ & & $x$ & \\
\hline & $x$ & & $x$ & \\
\hline & & & $x$ & \\
\hline & & & $x$ & \\
\hline & & $x$ & & \\
\hline ? & & $x$ & & \\
\hline & & ? & & \\
\hline & $x$ & & $x$ & \\
\hline
\end{tabular}

105-H Production Reactor

107-H Retention Basin

107-H Sludge Disposal Trench

107-H Reactor Effluent Piping

110-H Gas Storage

116-H Reactor Ventilation Exhaust

$$
\text { Stack }
$$

116-H-1 107-H Emergency Trench

116-H-2 1608-H Crib and Trench

116-H-3 Dummy Decontamination French Dra in

117-H Confinement Filter Building

118-H-1 Burial Ground

118-H-2 Burial Ground

118-H-3 Burial Ground

118-H-4 Burial Trench

118-H-5 Burial Trench

119-H Sample Building

115-H Substation

183-H Solar Still

190-HA Pumphouse Annex

1608-H Lift Station

1713-H Warehouse

1717-H Maintenance Shop

1720-HA Munitions Storage

1904-H Outfall 
Facilities that could be affected by wave action include 107-H (retention basin and portions of the effluent piping), 116-H-1, 118-H-1, and 1904-H.

Increased Susceptibility to Structural Failure. Accelerated corrosion of the 60-inch steel reactor effluent piping could be expected, leading to eventual collapse of this piping. Liquid waste disposal site 116-H-2 is reported to have consisted of a crib and a trench; accelerated decay of any timber framing in this crib could be expected.

Effects of elevated groundwater tables upon the seismic response of $100-\mathrm{H}$ facilities is not thoroughly understood at present; however, it is thought that a potential for soil liquefaction under seismic stress may exist (Task 2). 100-H structures thought to be potentially vulnerable to seismic events include the $105-\mathrm{H}$ production reactor building, $116-\mathrm{H}$, and $\mathrm{crib} 116-\mathrm{H}-2$. The footings of facilities 105- $\mathrm{H}, 107-\mathrm{H}$ (basin and piping), 116-, $117-\mathrm{H}$, and possibly 1608-H are situated on soil that would be saturated by the projected groundwater tables, leading to possible reduction in bearing capacity and differential settlement.

Structural damage by wave action may occur at 107-H (basin and piping).

Facilities 105-H, 107-H (basin and piping), 117-H, and possibly 1608-H could be subject to hydrostatic uplift. The metal storage basin of $105-\mathrm{H}$ is currently filled with soil; however, other spaces lie below the projected groundwater level of 410 feet.

Interference with Future Decommissioning Activities. The 100-H Area will not be isolated from the mainland at normal reservoir operating levels. However, spaces would be flooded within 105- H, 107-H (basin and trench), $117-\mathrm{H}, 116-\mathrm{H}-2$ crib (if existing), and possibly within 1608-H and the 116- -3 french drain (depths not known). Groundwater levels at 300,000 cfs would saturate buried radioactive materials at 107-H (basin and piping), 116-H-1, $116-\mathrm{H}-2,116-\mathrm{H}-3,118-\mathrm{H}-1,118-\mathrm{H}-2,118-\mathrm{H}-3$, and 1904-H.

Attractive Nuisances and Concealed Hazards. All 100-H above-ground structures would be visible and readily accessible from the shoreline. Facilities thought to present potentially severe hazards to unauthorized personnel include 105-H, 107-H (basin), 116-H, 117-H, 183-H (solar sti11), 
and 1608-H. The 1720-HA munitions storage building may also present a problem. Subsurface facilities within 1-mile of shore having voids or potential for collapse include the 107-H effluent piping, 116-H-3 if not backfilled with gravel, and $116-\mathrm{H}-2$ if a crib is present. All backfilled trenches present some possibility of fugitive surface contamination.

Interference with Operation. 100-H facilities are retired and have been declared surplus with the exception of the $183-H$ solar still and noncontaminated facilities used for storage. No interference with operation of these facilities would result from the proposed reservoir other than necessary rerouting of transportation facilities and utilities.

Decommissioning Activities and Estimated Costs

Recommended decommissioning activities and estimated costs for $100-\mathrm{H}$ facilities affected by the proposed reservoir are summarized in Table 14 . Costs are in 1979 dollars and are largely based on estimates prepared for the Hanford Decommissioning Planning Project. Costs include packaging of radioactive materials, transport to 200 West and interment in 200 West burial grounds. Comments on specific facilities follow.

Production Reactor and Ancillaries. Complete dismantling of the production reactor and ancillaries including $105-\mathrm{H}, 110-\mathrm{H}, 116-\mathrm{H}, 117-\mathrm{H}, 119-\mathrm{H}$, and 1608-H is proposed. This is in accordance with current DOE decommissioning planning for the 100-H Area. Cost estimates for this work are based on those compiled for D-Reactor by Vitro Engineering and have been adjusted to reflect design differences in the H-Reactor.

Retention Basin System. Dismantling of the 107-F retention basin and effluent piping is recommended, with removal of underlying and adjacent contaminated soil, which exceeds release limits. It is also recommended that the existing earth cover be removed from $1904-\mathrm{H}$ and contaminated concrete exceeding release levels be decontaminated or removed. Remaining structures would be reburied. The river discharge piping would be left in place unless contaminated to unacceptable levels. Removal of the $100-\mathrm{H}$ retention basin system is not contemplated in current DOE decommissioning planning but appear to be prudent if the dam is constructed. 
TABLE 14. Decommissioning Activities and Estimated Costs - 100-H Area

$\frac{\text { Facility }}{105-H \text { Production Reactor }}$
$107-H$ Retention Basin
$107-H$ Reactor Effluent Piping
$107-H$ Sludge Trench
$110-H$ Gas Storage
$116-H$ Reactor Ventilation Exhaust
Stack
$116-H-1$ 107 Emergency Trench

Decommiss ioning Act ivity

Dismant le.

Dismantle, remove underlying and

adjacent contaminated so il exceeding release limits.

Dismantle all sections between $105-\mathrm{H}$, $107-\mathrm{H}, 1608-\mathrm{H}$, and 1904-H.

No action required.

Dismant le.

Dismant le.

Remove contaminated soil exceeding release limits, remove 20 in. steel effluent line from $107-\mathrm{H}$ and 1907-H pumphouse.

Remove contaminated soil exceeding release limits, Remove effluent line from 1608-H. Backfill void.

Remove contaminated soil exceeding release limits. Remove effluent piping from 105-H Backfill void.

Dismant le.

Exhume buried radioactive material exceeding release limits.

Exhume buried radioactive material exceeding release limits.

Exhume buried radioactive material exceeding release limits.
Estimated Cost

$\$ 20,000,000$

$4,300,000$

$1,500,000$

$-$

20,000

165,000

$3,700,000$

780,000

11,000

230,000

$15,000,000$

810,000

$4,000,000$

118-H-3 Burial Ground 
TABLE 14. (contd)

\section{Facility}

118-H-4 Burial Trench

118-H-5 Burial Trench

119-H Sample Building

151-H Primary Substation

183-H Solar Still

190-HA Pumphouse Annex

1608-H Lift Station

1713-H Warehouse

1717-H Maintenance Shop

1720-HA Munitions Storage

1904-H Outfall
Decommissioning Activities

Install bio-barrier, fence.

Install bio-barrier, fence.

Remove slab.

No action required, would be removed

for complete site cleanup.

Provide new exclusion fencing if solar still is to be continued in use, otherwise dismantle.

No action required, dismantle for complete site cleanup.

Dismant le.

No action required, dismant le for complete site cleanup.

No action required, dismantle for complete site cleanup.

\section{Dismant le.}

Remove backfill, decontaminate weir box to release limits, backfill to grade. Effluent piping from 107-F will be removed (107-F Reactor Effluent Piping). River discharge piping will remain.

Total, 100-H
Est imated Cost

80,000

27,000

Negligible

Dismant ling cost should be covered by salvage value

18,000 (fencing)

180,000 (dismant le)

280,000

120,000 (dismant le)

150,000 (dismant le)

1,000

40,000

$\$ 51,000,000$ 
Liquid Waste Disposal Sites. Inventories of all liquid waste disposal sites in the 100-H Area would be wetted by elevated groundwater conditions. Excavation of contaminated soil exceeding release limits would be required for all liquid waste disposal sites $(116-\mathrm{H}-1,116-\mathrm{H}-2$, and $116-\mathrm{H}-3)$. 116-H-3 contains very low levels of activity and removal of soil may not be required. If this is the case, the effluent discharge line from $105-\mathrm{H}$ would be removed and any voids within the trench drain backfilled to prevent possible collapse. Cost estimates for removal of the liquid waste disposal sites are based on the model developed for the Hanford Decommissioning Planning Project and could vary significantly depending up on release criteria.

Solid Waste Disposal Sites. One of the five solid waste disposal sites at 100-H (118-H-1) will be partly flooded by reservoir waters. Two more, 118-H-2 and 118-H-3, will be wetted by elevated groundwater levels. Radioactive wastes and contaminated soil at these three facilities which exceed release limits would have to be removed prior to reservoir fill. Two remaining burial sites, 118-H-4 and 118-H-5, would not be affected by elevated surface or groundwater levels. However, it is recommended that these be placed into protective storage using the "bio-barrier" currently being tested at Pacific Northwest Laboratory to prevent intrusion of plants and animals (Cline 1976). This recommendation is contingent upon determination that transuranics or longlived fission products exceeding release criteria are not present at these sites. Estimated costs for removal of contaminated materials at $118-\mathrm{H}-1$, $118-\mathrm{H}-2$, and $118-\mathrm{H}-3$, and installation of bio-barriers at $118-\mathrm{H}-4$ and $118-\mathrm{H}-5$ are based upon results of the cost model developed for the Hanford Decommissioning Planning Project and could vary significantly depending upon release criteria.

Miscellaneous facilities. The proposed reservoir would not directly impact any of the miscellaneous facilities remaining at 100- $\mathrm{H}$, including 151- $\mathrm{H}, 183-\mathrm{H}$, 190-HA, 1713-H, 1717-H, and 1720-HA. However, it would be prudent to install improved security fencing at $183-\mathrm{H}$ if the solar still (used to evaporate radioactive liquids) continues to be used, and to install security fencing at 1720-HA if use of this facility is continued. It is expected that buildings 151-H, 190-HA, " 
1713-H, and 1720-H, plus unused roads and rail lines, would be removed in a general site cleanup following decommissioning of contaminated $100-\mathrm{H}$ facilities.

100-D Area

The 100-D reactors and ancillary facilities are located on a terrace exceeding 460 feet in elevation and would not be affected by projected increases in ground or surface water levels. Portions of the 100-D/DR Reactor effluent retention system (Figure 19) lie at lower elevations and near the shoreline of the proposed reservoir. Although none of these facilities would be submerged, elevated groundwater tables and proximity to the shoreline may result in adverse interactions.

Facilities Requiring Decommissioning

100-D facilities potentially requiring decommissioning are identified in Table 15. Interactions between the proposed reservoir and these facilities are summarized in Table 16.

Contaminated soil at 107-D and 116-DR-1 would be saturated by elevated groundwater levels. Samples of the affected soil indicate the presence of low specific activity material (Table 15) and analysis of potential release rates to the Columbia may indicate that removal is not required. An additional factor requiring consideration, however, is the proximity of contamination to the scarp that will form the reservoir shoreline. Past retention basin leakage is thought to have contaminated a volume of soil extending about 100 feet to the north of the retention basin, and lying within 300 feet of the scarp (Figure 19). Retreat of the scarp by wave action or sliding could release contaminated materials directly to the river. Although this contamination is generally low level, the probability of this release and resulting release rates should be assessed prior to establishing appropriate decommissioning action for $107-F$ and surrounding contamination.

Other contaminated facilities located within 300 feet of the reservoir shoreline are two outfalls, 1904-D and 1904-DR, and sections of effluent piping discharging from $107-D$ and $107-D R$ to the outfalls. 


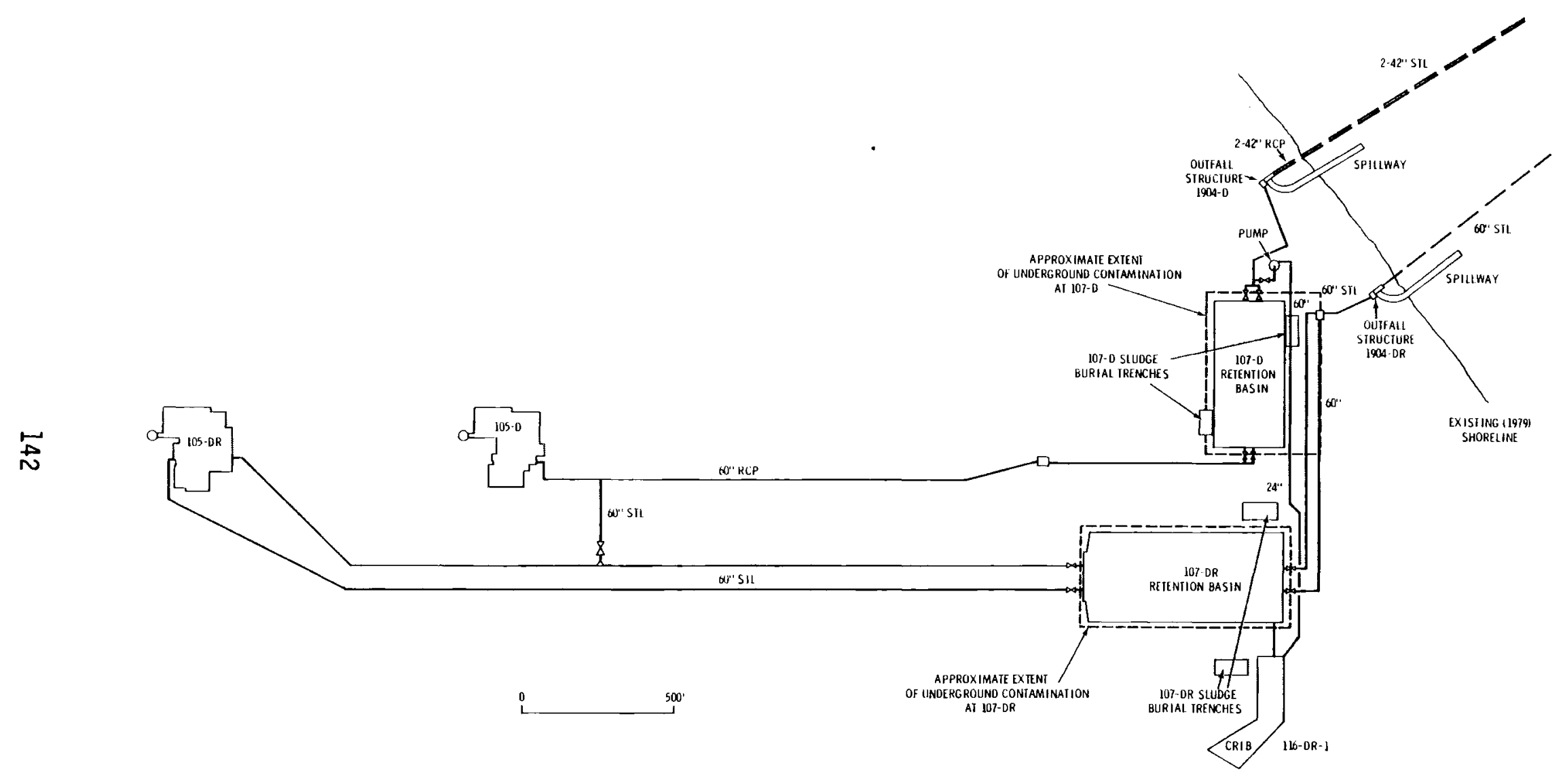

FIGURE 19. Effluent System, D and DR Reactors 


\section{TABLE 15. Facilities Potentially Requiring Decommissioning - 100-D Area} retention basin with 20 walls. Contains several adjacent soil contaminated from past basin leakage. Retired with $3^{2}-5^{\prime}$ of soil backfill.

107-DR Retention Basin - $230^{\circ} \times 600^{\circ}$ reinforced concrete retention basin with $20^{\circ}$ walls. Contains several inches of contaminated sludge. Underlying and adjacent soil contaminated from past basin
leakage. Retired with $1^{\prime}-3^{\prime}$ of soil backfill.

107-D Reactor Effluent Piping - A system of large diameter steel and reinforced concrete pipes for the transfer of $107-D R$ to $1904-D R$;

107-D Sludge Burial Trenches - Two trenches, approximately $251^{\prime} \times 50^{\prime}$ located adjacent to $107-D$.

107-DR Sludge Burial Trenches - Two trenches, approximately $25^{\circ} \times 50^{\prime}$ located near 107-DR.

116-DR-1 107 Emergency Trench - 40' $\times 400^{\prime}$ trench for disposal of reactor effluent following fuel cladding
failures. Serviced by a 24 " steel effluent line from $107-0$ and 107-0R. Retired and backfilled to grade.

181-D River Punphouse - Reinforced concrete and concrete block structure containing pumps for supplying river water to $100-D$ water treatment plants. In

1904-DR Outfall - $250 \mathrm{ft}^{2}$ weirbox with a 14 ' concrete spillway and (2) $42^{4}$ steel discharge lines to mid-river. Currently in use for discharge of water from 100-D filter plant.
107-D Retention Basin - 230' $\times 467$ ' reinf orced concrete inches of contaminated Sludge. Underlying and

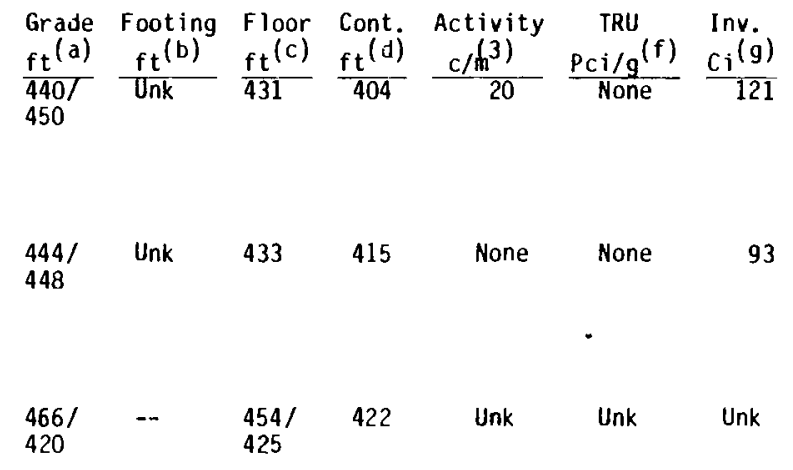

Not distinguishable from zone of contamination resulting from past 107-D leakage.

Not distinguishable from zone of contamination resulting from past 107-DR leakage.

$\begin{array}{lllllll}\begin{array}{l}440 / \\ 448\end{array} & -- & 424 & 410 & 10 & \text { None } & 3.1 \\ 416.5 & \text { Unk } & 41.9 & \text { None } & \text { None } & \text { None } & \text { None } \\ 420 & \text { Unk } & 425 & \text { Unk } & \text { Unk } & \text { Unk } & \text { Unk }\end{array}$

(a) Grade: The finished grade elevation of the facility in feet above sea level. A range may be given for facilities having no single finished grade.

(b) Footing The footing subgrade elevation of structures.

The elevation of the lowest floor of structures, the original trench or crib bottom of liquid and solid waste disposal $f$ acilities, and the invert of facilities comprised of piping.

(d) Cont: The lowest depth to which radioactive contamination is known to extend for a facility, in feet above sea level. In most cases the elevations entered into Cont. are based on results of the United Nuclear Industries sampling program reported in UNI-946. Because the reported depth is based on samples, it is possible that contamination might be present at even lower levels. Because samples were, in general, taken at locations likely to represent maximum penetra-

(e) Activity: The maximum level of radioactive contamination, in courits per minute, encountered in the predicted zone of saturation,

or below levels of flooding.

The maximum level of transuranic contamination, in picocuries per gram, encountered in the predicted zone of

(g) Inv: Saturation or below levels of flooding.

The estimated total radionuclide inventory of the facility, in curies. Included is all inventory present both within and above the zone of saturation or flooding. 
TABLE 16. Effects of Ben Franklin Reservoir on 100-D Area Facilities

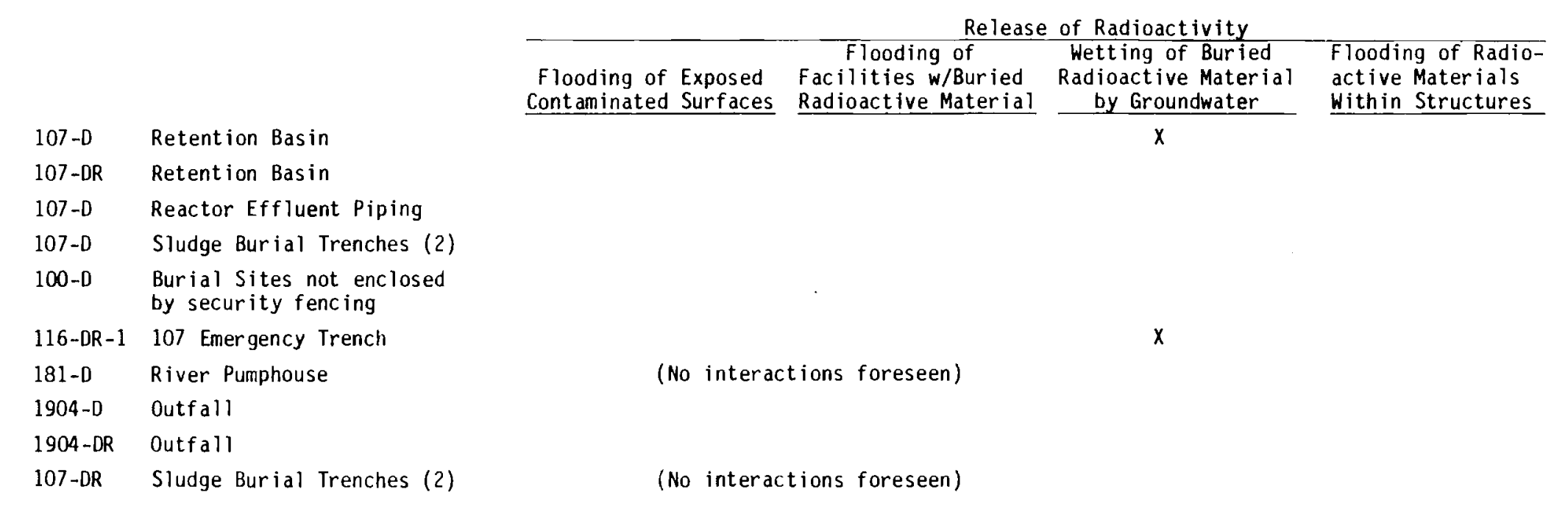

Release of

Radioactivity

Release of Radio-

active Materials

by Wave Action

$x$

\author{
$\begin{array}{ll}107-D & \text { Sludge Burial Trenches (2) } \\ 100-D & \text { Burial Sites not enclosed }\end{array}$ \\ $\begin{array}{ll}107-D & \text { Sludge Burial Trenches (2) } \\ 100-D & \text { Burial Sites not enclosed }\end{array}$ \\ by security fencing \\ 116-DR-1 107 Emergency Trench \\ 181-D River Pumphouse \\ 1904-D Outfall \\ 1904-DR Outfall \\ 107-DR Sludge Burial Trenches (2) \\ 107-D Retention Basin
}

Structural Failure

Deterioration Changes in Changes in

\begin{tabular}{c}
$\begin{array}{c}\text { of Structural } \\
\text { Material }\end{array}$ \\
\hline
\end{tabular}
Decommissioning

Hydrostatic Isolation of

Uplift 
TABLE 16. (contd)

\begin{tabular}{|c|c|c|c|c|}
\hline \multicolumn{2}{|c|}{ Decommissioning } & \multicolumn{2}{|c|}{ Hazard } & \multirow{2}{*}{$\begin{array}{c}\text { Operation } \\
\text { Interference } \\
\text { with Operation }\end{array}$} \\
\hline $\begin{array}{l}\text { Flooding of } \\
\text { Spaces With- } \\
\text { in Structures }\end{array}$ & $\begin{array}{l}\text { Flooding of Radioactive } \\
\text { Material Potentially } \\
\text { Requiring Excavation }\end{array}$ & $\begin{array}{l}\text { Attractive } \\
\text { Nuisances }\end{array}$ & $\begin{array}{c}\text { Concealed } \\
\text { Hazards }\end{array}$ & \\
\hline & $x$ & $x$ & & \\
\hline & & $x$ & & \\
\hline & & $x$ & $x$ & \\
\hline & & & $x$ & \\
\hline & & & $x$ & \\
\hline & $x$ & & $x$ & \\
\hline & & $x$ & & \\
\hline & & & $x$ & \\
\hline & & & $x$ & \\
\hline
\end{tabular}

\begin{abstract}
107-D Retention Basin
107-DR Retention Basin

107-D Reactor Effluent Piping

107-D Sludge Burial Trenches (2)

100-D Burial Sites not enclosed by security fencing
\end{abstract}

116-DR-1 107 Emergency Trench

181-D River Pumphouse

1904-D Outfall

1904-DR Outfall

107-DR Sludge Burial Trenches (2) 
Some interference with future decommissioning activities might be expected from penetration of groundwater into the contaminated soil underlying 107-D and 116-DR-1. As discussed above, the affected soil is contaminated only to low levels and assessment of potential release rates may indicate that removal would not be required with or without the proposed reservoir.

A significant problem associated with the 100-D facilities is the hazard these facilities would present to unauthorized visitors. The 100-D reactor complexes are enclosed by security fencing which should exclude all but the most determined; however, the two retention basins and the operating outfall are visible and readily accessible from shore. Proper protection would require fencing of these facilities if not dismantled. Other potential hazards include fugitive contamination at unfenced solid and liquid waste disposal sites. The large-diameter effluent piping is accessible at several points.

Active facilities at 100-D potentially affected by elevated ground and surface water levels include the 181-D pumphouse and 1904-D outfall. Projected reservoir levels are not expected to interfere with operation of these facilities.

\section{Decommissioning Activities and Estimated Costs}

Recommended decommissioning activities for 100-D facilities are summarized in Table 17. Dismantlement of 107-D and effluent piping downstream of 107-D and 107-DR, and removal of contaminated soil exceeding release limits at $107-D$ and $116-D R-1$ are recommended.

It is recommended that 107-DR, associated sludge burial trenches and the portions of effluent piping upstream of the retention basins be enclosed in security fencing. It is likely that removal of these facilities would ultimately be desirable because of transuranic contamination at both 107-DR and the effluent piping, and potential for collapse of the large-diameter pipe runs. These costs, however, are not considered to be attributable to the proposed reservoir.

Costs shown in Table 17 are in 1979 dollars and include packaging, transport, and burial of radioactive materials in 200 West burial grounds. Estimated costs for removal of contaminated soil at 116-DR-1 are based on the 


\section{TABLE 17. Decommissioning Activities and Estimated Costs - 100-D Area}

\begin{tabular}{ll}
\hline $107-D$ & Facility \\
$107-D R$ & Retention Basin \\
$107-D$ & Reactor Effluent Piping \\
$107-D$ & Sludge Burial Trenches \\
$107-D R$ & Sludge Burial Trenches \\
$116-D R-1$ & 107 Emergency Trench \\
$181-D$ & $\begin{array}{l}\text { River Pumphouse } \\
1304-D\end{array}$ \\
River Outfall \\
$1904-D R$ & River Outfall \\
$100-D$ & $\begin{array}{l}\text { Burial Sites Outside } \\
\text { of Existing Exclusion Area }\end{array}$
\end{tabular}

Decommissioning Activities

Dismant le, remove underlying and adjacent contaminated soil exceeding release limits.

Enclose in security fencing.

Dismantle sections downstream of 107-D and $107-D R$. Enclose remaining sections in security fencing.

Remove contaminated soil and sludge exceeding release limits as part of 107-D decommissioning effort.

Enclose in security fencing.

Remove contaminated soil exceeding release limits.

No decommissioning action required.

Remove residual contamination exceeding release limits

Remove soil backfill, decontaminate to release levels. Backfill to grade.

Enclose by security fence.
Est imated Cost, 1979 Dollars

$\$ 3,300,000$

150,000

Included in 107-DR

Included in 107-0

Included in 107-DR

$4,200,000$

$--$

15,000

20,000

Included with 107-DR

$\$ 7,700,000$ 
cost model developed for the Hanford Decommissioning Planning Project and could vary significantly depending upon release criteria.

$\underline{100-N \text { Area }}$

100 $\mathrm{N}$ Area facilities are largely situated at elevations of 450 to 460 feet, approximately 40 to 50 feet above predicted reservoir elevations at flood stage. With respect to $100-\mathrm{N}$ facilities, the 1966 Ben Franklin Dam study (Ballowe 1967) cites the proposed Emergency Waste Coolant Disposal Facility (not yet constructed) as being a potential problem with a $400-$ foot reservoir. No mention is made of possible effects on other facilities, although several appear to be potentially affected. It is recommended that the facilities listed in Table 18 be examined to determine if a 400-foot reservoir would affect the ir operation; and, in the case of $116-\mathrm{N}-1$, result in unacceptable releases of radioisotopes to the river. Determination of appropriate corrective actions, if required, must consider the anticipated construction schedule of the dam in relation to the period during which $100-\mathrm{N}$ is likely to be operating. The anticipated construction schedule of the dam is 14 years following initial appropriation of funds, giving a completion date of 1994 at the earliest. The design lifetime of $100-\mathrm{N}$ extends to 1990 and earlier termination of operations has been considered. Thus it is likely that corrective action would be limited to stabilization or removal of contaminated soil at 116-N-1. For this reason, examination of the possible effects of the proposed reservoir on $116-\mathrm{N}-1$ is considered to be the most important matter with respect to $100-\mathrm{N}$ at this time.

Construction of a security fence around $116-\mathrm{N}-1$ at an estimated cost of $\$ 76,000$ is considered to be necessary if this facility is to remain in place. $\underline{100-K \text { Area }}$

The 100-K reactor complexes and retention basins are situated at elevations of 438 feet or more and would not be affected by surface or groundwater levels resulting from the proposed reservoir. Portions of the retention basin system would be submerged by reservoir waters or contain contaminated materials that would be saturated by elevated groundwater levels. 
TABLE 18. 100-N Facilities Potentially Affected by a 400-Foot Reservoir

Facility

116-N-1 Crib and Trench

181-N River Pumphouse

181-NE River Pumphouse

$\vec{b}$

1908-N Outfall

1908-NE Outfall

Proposed Emergency Disposal Basin

Tank, NE of $1908-\mathrm{N}$

\section{Potential Impacts}

Effect of elevated groundwater levels on release of existing inventory to the river. Effect of elevated groundwater on effectiveness of soil column.

Effect of reservoir on pump operation and maintenance.

Effect of reservoir on pump operation and maintenance.

Effect of reduced hydraulic head on discharge rates.

Effect of reduced hydraulic head on discharge rates.

Effect of elevated groundwater levels on absorption column.

Effect of reservoir and groundwater levels on bearing capacity and seismic response. 


\section{Facilities Requiring Decommissioning}

100-K facilities requiring decommissioning are identified in Table 19, and may be located on Figure 20. Interactions between predicted ground and surface water levels are summarized in Table 20.

Portions of the reactor effluent lines to the north of the perimeter patrol road and the 1908-K outfall will be partly submerged at normal reservoir operating levels. Radioactive contamination of these facilities is not known. However, it is likely that contamination levels are similar to that found in equivalent facilities in other reactor areas: scale contaminated at low or moderate levels in the effluent piping and low level surface contamination in the outfall structure.

Contaminated soil will be saturated by elevated groundwater at the 116-K-1 emergency $\mathrm{crib}$ and the 166-K-2 emergency trench. Specific activity of the affected portion of $116-\mathrm{K}-1$ is low (Table 19) and analysis of release rates may indicate that soil excavation is not required. A more significant problem appears to exist at $116-\mathrm{K}-2$, where specific activity of underlying soil is higher and "washouts" during trench operation contaminated a large area of soil extending north of the trench (Figure 20). Topographic maps of the contaminated area were not located for this writing, but it is possible that portions of this contaminated area may be flooded at normal reservoir operating levels.

Effects on structural materials would be limited to possible settlement and accelerated corrosion of flooded portions of the reactor effluent piping.

Some interference with future decommissioning activities could be expected by intrusion of groundwater into contaminated portions of $116-\mathrm{K}-1$ and $116-\mathrm{K}-2$ and partial flooding of the effluent piping and outfall.

Facilities posing hazards to unauthorized visitors would include the 116-K-2 trench and adjacent areas of near-surface contamination. Possibility of fugitive surface contamination at $116-K-2$ would make enclosure of this facility desirable if it is not decontaminated to release levels.

No interference with operation of the 181-KE and 181-KW pumphouses is expected. Pumproom floors are well above maximum predicted reservoir levels 
TABLE 19. Facilities Potentially Requiring Decommissioning - 100-K Area

107-K Reactor Effluent Piping A system of large diameter steel and reinforced concrete pipes for the
transfer of reactor effluent from $105-\mathrm{KE}$ and $105-\mathrm{KW}$ to $107-\mathrm{KE}$ and $107-\mathrm{KW}$, respectively, and from $107-K E$ and $107-\mathrm{KW}$ to $1908-\mathrm{K}$. Also inc luded are pipes for discharge of effluent from $105-\mathrm{KE}, 105-\mathrm{KW}, 107-\mathrm{KE}$ and $107-\mathrm{KW}$ to $116-K-1$ and $116-K-2$.

181-KE River Pumphouse

A structure housing pumps for supply of reactor cooling water to the $\mathrm{KE}$ water treatment plant.

181-KW River Pumphouse

116-K-1 107 Emergency Crib

A structure housing pumps for supply of reactor cooling water to the $K W$ water treatment plant. disposal of reactor effluent following fuel cladding failures. Retired.

116-K-2 107 Emergency Trench $45^{\prime} \times 4000^{\prime}$ trench for disposal of reactor effluent following fuel cladding failures plus miscellaneous liquid waste from the $k$ reactors. Retired and backfilled to grade.

1908-K Outfall

$$
\begin{aligned}
& \text { A } 1200 \mathrm{ft}^{2} \text { we irbox with a concrete } \\
& \text { spillway and two } 84 " \text { steel discharge } \\
& \text { lines to mid-river. In use for } \\
& \text { discharge of misce } 11 \text { aneous waste water } \\
& \text { from 100-K Area facilities. }
\end{aligned}
$$

\begin{tabular}{|c|c|c|c|c|c|c|}
\hline $\begin{array}{l}\text { Grade } \\
\text { ft(a) }\end{array}$ & $\begin{array}{c}\text { Footing } \\
\mathrm{ft}(\mathrm{b})\end{array}$ & $\begin{array}{l}\text { Flgor } \\
\text { ftlc } \\
\end{array}$ & $\begin{array}{l}\text { Cont. } \\
\mathrm{ft} \text { (d) }\end{array}$ & $\begin{array}{c}\text { Actiyity } \\
c / m(e)\end{array}$ & $\begin{array}{c}\operatorname{TRU} \\
\mathrm{Pci} / \mathrm{g}(\mathrm{f}) \\
\end{array}$ & $\begin{array}{l}\text { Iny. } \\
\mathrm{C}(\mathrm{j})\end{array}$ \\
\hline $\begin{array}{l}430 / \\
474\end{array}$ & -- & $\begin{array}{l}404 / \\
467\end{array}$ & Unk & Unk & $u_{1}$ & \\
\hline
\end{tabular}

Unk

354.5421 .0 None None None None
354.5421 .0 None None None None

Unk $354.5 \quad 421.0$ None None None None

$\begin{array}{lllllll}422 / & -- & 392 / & 380 & 30 & 0.0032 & 46\end{array}$

$\begin{array}{lllllll}437 / & - & 422 / & 379 & 12,000 & 130 & 2100\end{array}$

$443-428$

Unk $\quad 404$

Unk

Unk

Ta) Grade: The finished grade elevation of the facility in feet above sea level. A range may be given for facilities having no single finished grade.

(b) Footing: The footing subgrade elevation of structures.

(c) Floor: The elevation of the lowest floor of structures, the original trench or crib bottom of liquid and solid waste disposal

facilities, and the invert of facilities comprised of piping.

(d) Cont:: The lowest depth to which radioactive contamination is known to extend for a facility, in feet above sea level. In most cases the elevations entered into Cont. are based on results of the United Nuclear Industries sampling program reported in UNI-946. Because the reported depth is based on samples, it is possible that contamination might be present at even in UNI-946. Because the reported depth is based on samples, it is possible that contamination might be present
lower levels. Because samples were, in general, taken at locations likely to represent maximum penetration of contamination, these figures are probably fairly representative of the maximum penetration of contamination.

(e) Activity: The maximum level of radioactive contamination, in counts per minute, encountered in the predicted zone of saturation, or

(f) The maxum level of transuranic contamination, in picocuries per gram, encountered in the predicted zone of saturation

(g) Inv: The estimated total radionuclide inventory of the facility, in curies. Included is all inventory present both within and above the zone of saturation or flooding. 


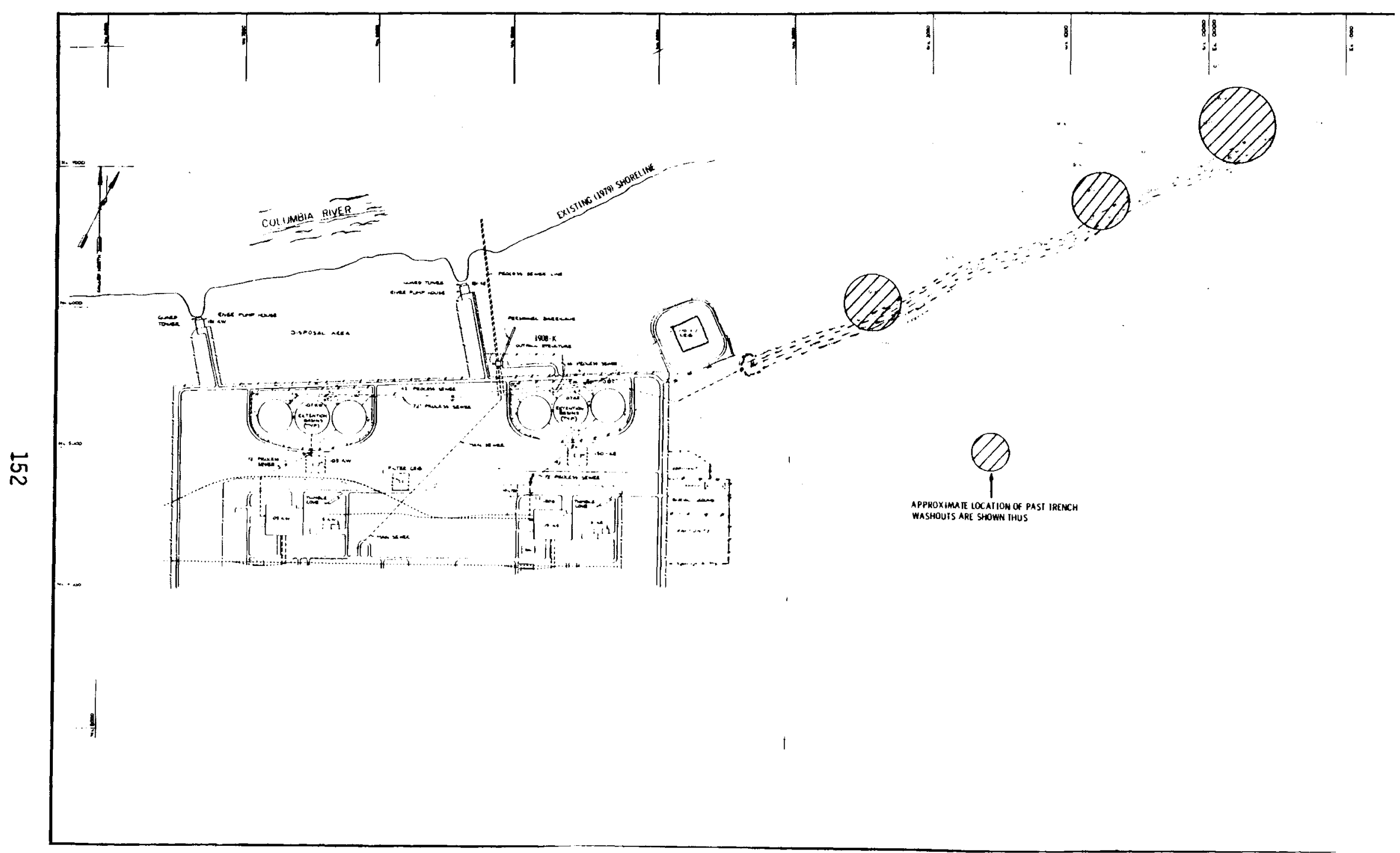

FIGURE 20. 100-K Area and Washouts 


\section{TABLE 20. Effects of Ben Franklin Reservoir on 100-K Area Facilities}

107-K Reactor Effluent Piping

116-K-1 107 Emergency Crib

$116-K-2 \quad 107$ Emergency Trench

1904-K Outfall

181-KE River Pumphouse

181-KW River Pumphouse

\section{7-K Reactor Effluent Piping}

116-K-1 107 Emergency Crib

116-K-2 107 Emergency Trench

1904-K Outfall

181-KE River Pumphouse

181-KW River Pumphouse
Release of Radioactivity

\begin{tabular}{cccc}
\hline $\begin{array}{c}\text { Flooding of Exposed } \\
\text { Contaminated Surfaces }\end{array}$ & $\begin{array}{c}\text { Flooding of } \\
\text { Radioactive Material }\end{array}$ & $\begin{array}{c}\text { Wetting of Buried } \\
\text { Radioactive Material } \\
\text { by Groundwater }\end{array}$ & $\begin{array}{c}\text { Flooding of Radio- } \\
\text { active Materials }\end{array}$ \\
\cline { 2 - 3 } Whuctures
\end{tabular}

$x$

\section{$?$}

$x$

(No interactions foreseen)

(No interactions foreseen)
Release of

$\frac{\text { Radioactivity }}{\text { Release of Radio- }}$ Release of Radio-
active Materials

by Wave Action

\begin{tabular}{l}
$\frac{3}{\text { Structural Failure }}$ \\
$\begin{array}{l}\text { Deterioration Changes in Changes in } \\
\text { of Structural Seismic }\end{array}$ \\
Material Bearing \\
\hline
\end{tabular}

$x$

$x$

$x$

\begin{tabular}{c} 
Decomissioning \\
$\begin{array}{l}\text { Hydrostatic Isolation of } \\
\text { Uplift } \\
\text { Facility }\end{array}$ \\
\hline
\end{tabular}

$?$ 
TABLE 20. (contd)

\begin{tabular}{|c|c|c|c|c|}
\hline \multicolumn{2}{|c|}{ Decommissioning } & \multicolumn{2}{|c|}{ Hazard } & \multirow{2}{*}{$\begin{array}{c}\text { Operation } \\
\begin{array}{l}\text { Interference } \\
\text { with Operation }\end{array}\end{array}$} \\
\hline $\begin{array}{l}\text { Flooding of } \\
\text { Spaces With- } \\
\text { in Structures }\end{array}$ & $\begin{array}{l}\text { Flooding of Radioactive } \\
\text { Material Potentially } \\
\text { Requiring Excavation }\end{array}$ & $\begin{array}{l}\text { Attractive } \\
\text { Nu isances }\end{array}$ & $\begin{array}{c}\text { Concealed } \\
\text { Hazards }\end{array}$ & \\
\hline \multicolumn{5}{|l|}{$x$} \\
\hline & $x$ & & & \\
\hline & $x$ & & $x$ & \\
\hline
\end{tabular}

116-K-1 107 Emergency Crib

116-K-2 107 Emergency Trench

1904-K Outfall

$\underset{\leftrightarrow}{\mathfrak{B}}$

181-KE Kiver Pumphouse

$x$

(No interactions foreseen)

(No interactions foreseen) 
and all nonwatertight equipment is reported to be above the pumproom floor level. Effects of increased reservoir levels on operation of the river outfall is not known at this writing. However, it is possible that decreased hydraulic head may interfere with flow through the river outfall lines.

\section{Decommissioning Activities and Estimated Costs}

Recommended decommissioning activities for 100-K facilities are summarized in Table 21. It is recommended that portions of the effluent piping below predicted flood stages (approximately 413 feet) be surveyed for radioactive contamination and decontaminated to release levels, perhaps by use of vacuum-blast equipment. A similar treatment would be appropriate for the 1908-K outfall. Decontaminated structures and piping could be removed if $100-K$ facilities were declared surplus.

Contaminated soil exceeding release levels would be removed from $116-k-1$ and 116-K-2. Removal of the effluent lines servicing these facilities would also be desirable.

Estimated costs cited in Table 21 are in 1979 dollars and include packaging, transport, and burial of radioactive materials in 200 West. Costs for dismantling $116-K-1$ and $116-K-2$ are based on removal of estimated volumes of contaminated soil and could vary significantly depending upon release criteria. 100-B Area

No facilities would be flooded at 100-B. However, elevated groundwater levels would saturate contaminated soil underlying several facilities associated with the reactor effluent discharge system.

Facilities Requiring Decommissioning

100-B facilities requiring decommissioning are identified in Table 22 and may be located on Figure 21. Interactions between predicted ground and surface water levels and these facilities are summarized in Table 23.

Subsurface contamination at the $107-B$ and $107-C$ retention basins and the 116-C-1 emergency trench will be exposed to elevated groundwater levels. Included would be portions of a large volume of contaminated soil extending toward the river from 107-B (Figure 21) resulting from past basin leakage. 
TABLE 21. Decommissioning Activities and Estimated Costs - 100-K Area

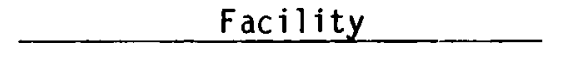

107-K Reactor Effluent Piping

181-KE River Pumphouse

181-KW River Pumphouse

$116-K-1$ Emergency Crib

116-K-2 Emergency Trench

$1908-K$ Outfall
Decommissioning Activities

Remove internal contamination exceeding release limits in sections below $420 \mathrm{ft}$ by vacuum blasting. Alternatively, if $100-K$ is not to remain in standby, remove sections of effluent piping below $420 \mathrm{ft}$.

No decommissioning action required

No decommissioning action required

Remove contaminated soil exceeding release levels. Remove effluent piping to valve box

Remove contaminated soil exceeding release levels. Remove effluent piping to valve box

Remove internal contamination exceeding release limits by vacuum blasting.

Alternatively, if $100-K$ is not to

remain in standby, dismantle.

$$
\text { Total }-100-K
$$

Estimated Costs 1979

$\$ 100,000$ (decontamination)

$3,700,000$

$18,000,000$

40,000 (decontamination)

$22,000,000$ 
TABLE 22. Facilities Potentially Requiring Decommissioning 100-B Area

107-B Retention Basin

$230^{\circ} \times 457^{\prime}$ reinforced concrete retention basin with $20^{\prime}$ walls. Contains several inches of contaminated sludge. several inches of cont aminated sludge. Under lying and adjacent soil is contamwith about $4 \mathrm{ft}$ of soil backfill.

苞 from past basin leakage. Retired with
107-C Retention Basins

107-8 Sludge Burial Trench (north)

107-8 Sludge Burial Trench (south)

107-B Reactor Effluent Piping

Two stee 1 tanks, $330 \mathrm{ft}$ diameter and $16 \mathrm{ft}$ deep on concrete slabs. Contain less than one inch of contaminated sludge plus contaminated scale which has fallen from the tank walls. Underlying and adjacent soil is contaminated about $4 \mathrm{ft}$ of soil backfill.

A $10^{\prime} \times 120^{\prime}$ trench for disposal of sludge from $107-B$, located to the north of 107-B. Retired and backfilled. Located within the general zone of contamination resulting from past 107-B basin leakage.

A trench, approximately $30^{\prime} \times 30^{\prime}$ for disposal of sludge from 107-B locate to the south of 107-B. Retired and backfilled. Located with in the general zone of contamination resulting from past 107-B basin leakage.

A system of large diameter steel and reinforced concrete pipes for the transfer of reactor effluent from 105-B transfer of reactor effluent from $105-C$ to $107-B$ and $107-C$, and from and $105-C$ to $107-B$ and $107-C$, and from $107-B$ and $107-C$ to outfalls $1904-B 1$,
$1904-B 2$, and $1904-C$. Also included are pipes for discharge of effluent from $107-B$ to $116-B-1$ and from $107-C$ to

116-C-1.

116-B-1 107 Emergency Trench

A $50^{\prime} \times 500^{\prime}$ trench for disposal of reactor effluent following fuel cladding failure. Retired and backfilled to grade.

\begin{tabular}{|c|c|c|c|c|c|c|}
\hline $\begin{array}{l}\text { Grade } \\
\mathrm{ft}(\mathrm{a})\end{array}$ & $\begin{array}{l}\text { Footing } \\
\mathrm{ft}(\mathrm{b})\end{array}$ & $\begin{array}{l}\text { Flgor } \\
\mathrm{ft}(\mathrm{c})\end{array}$ & $\begin{array}{l}\text { Cont. } \\
\mathrm{ft} \text { (d) }\end{array}$ & $\begin{array}{c}\text { Actiyify } \\
\mathrm{c} / \mathrm{m}(\mathrm{e}) \\
\end{array}$ & $\begin{array}{c}\text { TRU } \\
\mathrm{Pci} / \mathrm{g}(f) \\
\end{array}$ & $\begin{array}{l}\operatorname{Iny} . \\
\mathrm{Ci}\end{array}$ \\
\hline 436 & Unk & 422 & 397 & 3500 & 7.6 & 422 \\
\hline 431 & Unk & 430 & 409 & 1500 & 0.29 & 187 \\
\hline 434 & -- & 428 & 412 & 15 & None & 0.8 \\
\hline 440 & - & 434 & Unk & Unk & Unk & Unk \\
\hline $\begin{array}{l}432 / \\
494\end{array}$ & -- & $\begin{array}{l}420.5 / \\
486\end{array}$ & 395 & 40 & None & Unk \\
\hline 435 & -- & 420 & 416 & None & None & 3.1 \\
\hline
\end{tabular}




\section{TABLE 22. (contd)}

116-C-1 107 Emergency Trench A 50' $\times 500^{\prime}$ trench for disposal of reactor effluent following fuel cladding failure. Retired and backfilled to grade.

1904-B1 Outfall

1904-B2 Outfall

1904-C Outfall

181-C River Pumphouse
$300 \mathrm{ft}^{2}$ reinforced concrete we ir box with a concrete spillway and a single discharge pipe to mid-river. In use, receiving water from $100-B$ water treatment plant.

$300 \mathrm{ft}^{2}$ reinforced concrete we ir box with a concrete spillway and a $66^{\prime}$ steel discharge pipe to mid-river. Ret ired.

$300 \mathrm{ft}^{2}$ reinforced concrete we ir box with a concrete spillway and two 54 in. steel discharge pipes to mid-river. Retired.

Re inforced concrete and concrete block structure containing pumps for supplying river water to $100-B$ wate treatment plant. In use to supply export water to 200 Areas.

Reinforced concrete and concrete block structure containing pumps for supplying river water to $100-B$ water supplying river water to $100-B$ water
treatment plant. In use to supply export water to 200 Areas.

$\begin{aligned} & \text { Grade } \\ & \mathrm{ft}(\mathrm{a})\end{aligned}$
$\begin{aligned} & 435 / \\ & 445\end{aligned}$

«32 Unk 420.5 Unk Unk Unk Unk

$\sim 432$ Unk 420 Unk Unk Unk Unk

ح432 Unk 423 Unk Unk Unk Unk

424.5 Unk 427 None None None None

(a) Grade: The finished grade elevation of the facility in feet above sea level. A range may be given for facilities having no

(b) Footing: The footing subgrade elevation of structures.

(c) Floor: The elevation of the lowest floor of structures, the original trench or crib bottom of liquid and solid waste disposal

(d) Cont. facilities, and the invert of facilities comprised of piping.

The lowest depth to which radioactive contamination is known to extend for a facility, in feet above sea level. In most cases the elevations entered into Cont. are based on results of the United Nuclear Industries sampling program reported in UNI-946. Because the reported depth is based on samples, it is possible that contamination might be present at even lower levels. Because samples were, in general, taken at locations likely to represent maximum penetration of contamination, these figures are probably fairly representative of the maximum penetration of contamination.

(e) Activity: The maximum level of radioactive contamination, in counts per minute, encountered in the predicted zone of saturation,

(f) TRU: or below levels of flooding.

(g) Inv: The estimated total radionuclide inventory of the facility, in curies. Included is all inventory present both within and above the zone of saturation or flooding. 


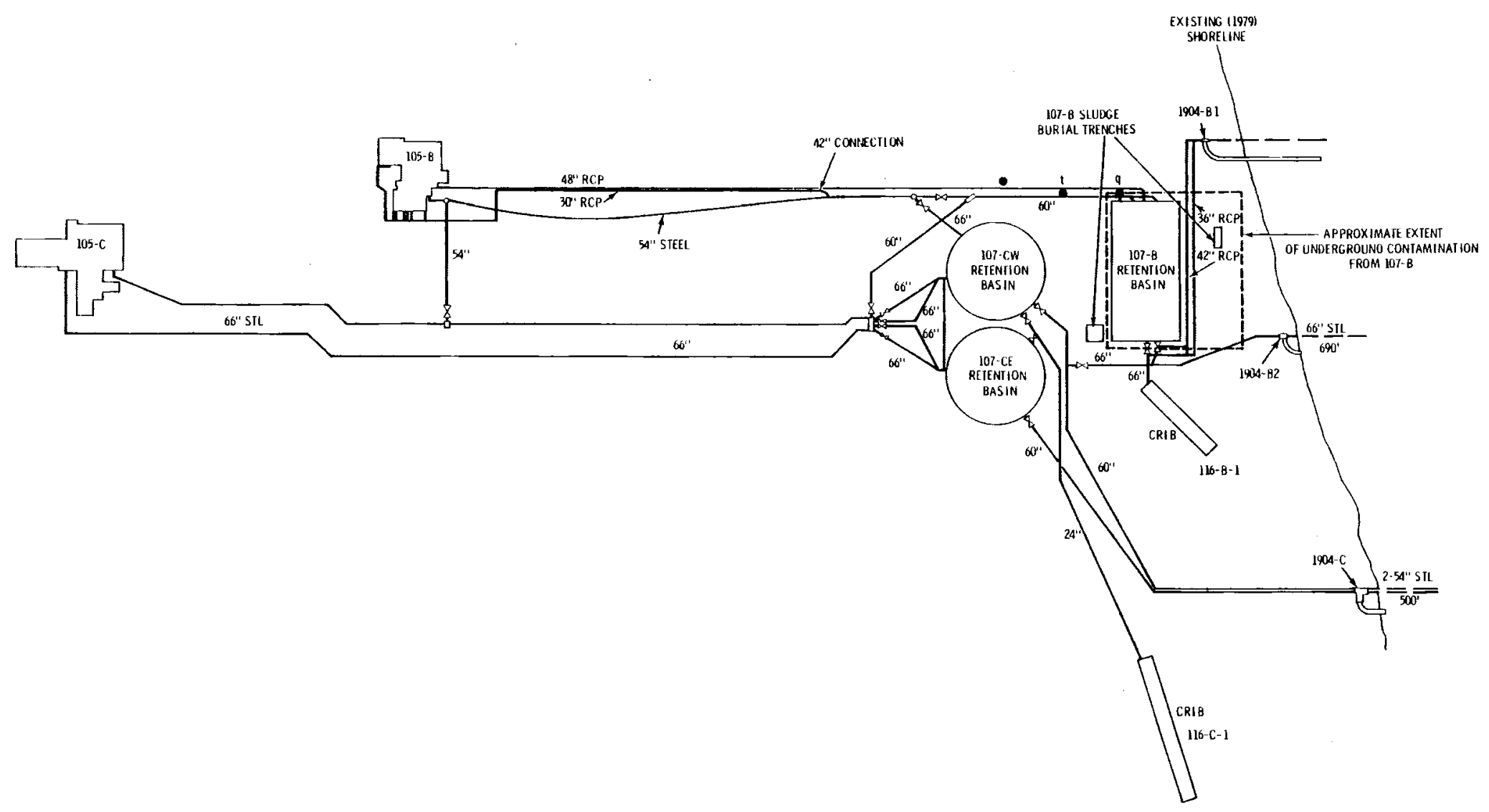

FIGURE 21. Reactor Retention Basin System, B and C Reactors (Not to Scale) 


\section{TABLE 23. Effects of Ben Franklin Reservoir on 100-B Area Facilities}

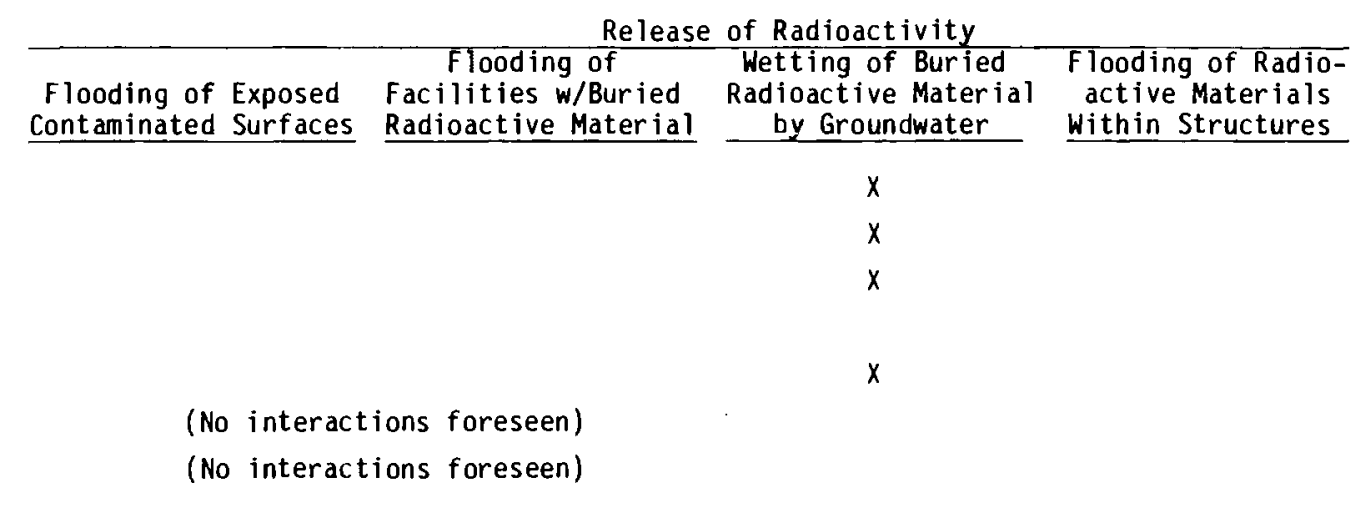

107-B Retention Basin

107-C Retention Basins

107-B Effluent Pipe

107-B Sludge Burial Trenches

116-C-1 107 Emergency Trench

181-B River Pumphouse

181-C River Pumphouse

1904-B1 Outfall

1904-B2 Outfall

1904-C Outfall

芩

107-B Retention Basin

107-C Retention Basins

107-B Effluent Pipe

107-B Sludge Burial Trenches

116-C-1 107 Emergency Trench

181-B River Pumphouse

181-C River Pumphouse

1904-B1 Outfall

1904-B2 Outfall

1904-C Outfall
Release of

Radioactivity

Release of Radio-

active Materials

Deterioration Changes in Changes in

of Structural Seismic Bear

Material

Capacity

Hydrostat ic

Uplift

Decommissioning

$x$ (North Trench)
Isolation of Facility 
TABLE 23. (contd)

\begin{tabular}{ll}
\multicolumn{2}{c}{ Decommissioning (contd.) } \\
\hline Flooding of Flooding of Radioactive \\
Spaces With- Material Potentially \\
in Structures & Requiring Excavation \\
\cline { 2 - 3 }
\end{tabular}

\begin{tabular}{|c|c|c|}
\hline $\mathrm{Haz}$ & & Operation \\
\hline $\begin{array}{l}\text { tractive } \\
\text { jisances }\end{array}$ & $\begin{array}{c}\text { Concealed } \\
\text { Hazards }\end{array}$ & $\begin{array}{c}\text { Interference } \\
\text { with Operation }\end{array}$ \\
\hline
\end{tabular}

107-B Retention Basin

107-C Retention Basins

107-B Effluent Pipe

107-B Sludge Burial Trenches

116-C-1 107 Emergency Trench

181-B River Pumphouse

181-C River Pumphouse

1904-B1 Outfall

1904-82 Outfall

$x$

$x$

$x$

$x$

$x$

$x$ $x$

$x$

$x$

$x$

$x$

1904-C Outfall 
Contaminated soil underlies sections of effluent piping at sites of past leakage and in areas that would be saturated by projected groundwater levels. Examples include sample holes $q, t$, and $u$ (Figure 21) where contamination has been found at elevations of 409,410 , and 395 feet, respectively.

The 107-B retention basin, portions of the effluent piping leading to the outfall structures, the north 107-B sludge disposal trench and outfall structures 1904-B1, 1904-B2, and 1904-C will be within 300 feet of the reservoir shoreline and may be subject to bank erosion. Although additional investigation would be required to verify if a potential problem with bank erosion may exist, it is assumed that the 300-foot reservoir buffer strip would be cleared of all structures and hazardous materials.

Saturation of contaminated soils by groundwater at 107-B (basin and piping), $107-C$ and $116-C-1$ could interfere with future decommissioning efforts. No other interferences are foreseen.

The 107-B and 107-C retention basins and the 1904-B1 outfall would be visible from shore and are judged to be significant attractive nuisances. Sections of the effluent pipeline are accessible through manholes and would constitute a less visible, although potentially significant, hazard. Fugitive surface contamination at the 100-B burial sites and the retention system facilities would make decontamination or fencing of these areas desirable. Other 100-B facilities are enclosed by security fencing, which should adequately exclude the curious.

The $B$ and $C$ reactor plants are currently in standby status; however, if these plants are retired prior to reservoir fill no operational conflicts would occur. 181-B, 181-C, and 1904-B1 are in use in association with the export water treatment plant; no interference with operation of these facilities is expected.

Decommissioning Activities and Estimated Costs

Recommended decommissioning activities and estimated costs for 100-B facilities are summarized in Table 24. B-Reactor and C-Reactor are assumed to be in surplus status by the time of reservoir fill, allowing removal 
TABLE 24. Decommissioning Activities and Estimated Costs - 100-B Area

Facility

107-B Retention Basin

107-C Retention Basin

107-B/C Reactor Effluent Piping

107-B Sludge Disposal Trenches

116-B-1 107 Emergency Trench

1904-B1 Outfall

1904-B2 Outfall

1904-C Outfall

100-B Burial Sites outside of existing exclusion area

Decommissioning Activities

Dismantle, remove adjacent and underlying contaminated soil exceeding release limits

Dismantle, remove adjacent and underlying contaminated soil exceeding release limits

Dismantle, remove adjacent and underlying contaminated soil exceeding release limits

Will be removed in conjunction with dismantling of $107-B$

Install bio-barrier and exclusion fencing. Remove effluent discharge line

Remove contaminated soil exceeding release limits. Remove effluent discharge line

Decontaminate to release limits

Remove soil cover, decontaminate to release limits. Retain river discharge piping unless contaminated above release limits

Remove soil cover, decontaminate to release limits. Retain river discharge piping unless contaminated above release limits

Enclose by security fencing

Estimated Cost

$\$ 3,300,000$

$4,400,000$

$6,000,000$

310,000

$5,700,000$

15,000

35,000

35,000

125,000

Total, 100-B
$\$ 20,000,000$ 
of the effluent discharge systems. Recommended for dismantling are the 107-B and 107-C retention basins and $116-C-1$. Removal of the entire effluent piping system and surrounding contaminated soil exceeding release 1 imits is also recommended. Even though only portions of the effluent piping system (sections downstream of the retention basins and sections having deep underlying contamination) may present problems from the standpoint of the proposed reservoir, it may be expeditious to dismantle the entire system once equipment is staged for the job.

It is recommended that the 1904-B2 and 1904-C outfalls be excavated in conjunction with effluent pipe removal and decontaminated to release levels. The river outfall piping would remain in place unless found to be contaminated to unacceptable levels. 1904-B1 (operating) would be surveyed and decontaminated to release levels at the time of effluent pipe removal. Retired and decontaminated outfalls would be covered with clean soil.

The 100-B burial sites not presently enclosed by security fencing would be enclosed to deter unauthorized access.

600 Area

600 Area facilities potentially affected by the proposed reservoir are listed in Table 25.

\section{$\underline{316-4}$}

Crib 316-4 is located slightly west of Route 4 South about 5 miles north of the 300 Area in an area, which although remote from the proposed reservoir, would be affected by rising groundwater tables. The projected groundwater elevation at this site is 385 feet, approximately 53 feet below grade. The 316-4 crib is of inverted tank design, allowing liquid discharged to the crib (via standpipe) to percolate into the soil. No information as to the depth of the crib bottom or contamination profiles was available at the time of this writing to determine whether contaminated material would be subject to leaching by groundwater.

It is recommended that core samples be taken at this facility to determine the contamination profile and leaching properties of the soil. Leaching and transport rates can then be modeled (if contamination is found below projected groundwater levels) to determine acceptable release criteria for this facility. 


\section{TABLE 25. 600 Area Facilities Potentially Affected by a $400 \mathrm{ft}$ Reservoir}

316-4 Crib

318-10 Burial Ground

318-11 Burial Ground

WBF -1 Ecosystems Storage

के WBF-2 Ecosystems Storage
Two buried inverted stainless steel tanks used for disposal of hexonebearing and other uranium wastes from the 300 Area. Inactive.

A $485^{\prime} \times 570^{\prime}$ burial ground used for disposal of dry radioactive wastes (primarily fission products and uranium) and beryllium wastes from 300 Area operations. Inactive.

A $375^{\prime} \times 1000^{\prime}$ burial ground for disposal of dry radioactive wastes, primarily fission products and plutonium, from 300 Area operations. Inactive.

Metal boat shed, approximately $20^{\prime} \times 60^{\prime}$. Active.

Metal storage building, approximately $20^{\prime} \times 30^{\prime}$. Active.

\begin{tabular}{|c|c|c|c|c|c|c|}
\hline $\begin{array}{l}\text { Grade } \\
\mathrm{ft}(\mathrm{a})\end{array}$ & $\begin{array}{r}\text { Footing } \\
\text { ft }(b)^{2}\end{array}$ & $\begin{array}{l}F l o o r \\
\mathrm{ft}(\mathrm{c}) \\
\end{array}$ & $\begin{array}{l}\text { Cont. } \\
\text { ft (d) }\end{array}$ & $\begin{array}{c}\text { Actiyity } \\
c / m(e)\end{array}$ & $\begin{array}{c}T R U \\
\mathrm{Pci} / \mathrm{g}(f) \\
\end{array}$ & $\begin{array}{l}\text { Iny } \\
C_{i}(\dot{g})\end{array}$ \\
\hline 438 & Unk & Unk & Unk & Unk & -- & $2070 \mathrm{~kg}$ \\
\hline 430 & -- & 405 & Unk & Unk & Unk & 2000 \\
\hline 430 & -- & 405 & Unk & Unk & Unk & 2000 \\
\hline 400 & 400 & 400 & None & None & None & None \\
\hline 400 & 400 & 400 & None & None & None & None \\
\hline
\end{tabular}

(a) Grade: The finished grade elevation of the facility in feet above sea level. A range may be given for facilities having no single finished grade.

(b) Footing: The footing subgrade elevation of structures.

(c) Floor: The elevation of the lowest floor of structures, the original trench or crib botton of liquid and solid waste disposal

The lowest depth to which radioactive contamination is known to extend for a facility, in feet above sea level. In most cases the elevations entered into Cont, are based on results of the United Nuclear Industries sampling program reported in UNI-946. Because the reported depth is based on samples, it is possible that contamination might be present at even lower levels. Because samples were, in general, taken at locations likely to represent maximum penetration of contamination, these figures are probably fairly representative of the maximum penetration of contamination.

(e) Activity: The maximum level of radioactive contamination, in counts per minute, encountered in the predicted zone of saturation, or below levels of flooding.

(f) IRU: The maximum level of transuranic contamination, in picocuries per gram, encountered in the predicted zone of saturation or below levels of flooding.

(g) Inv: The estimated total radionuclide inventory of the facility, in curies. Included is all inventory present both within and above the zone of saturation or flooding. 
318-10 (North Burial Ground)

Burial ground 318-10 is siightly west of 316-4. Projected groundwater tables are approximately 390 feet, about 15 feet below the trench bottoms. 318-10 was used for disposal of dry wastes and there would be little reason to expect penetration of contamination far below the original trench bottoms. Thus, it does not appear that projected changes in the groundwater level would unfavorably interact with this burial site. To resolve remaining uncertainties it is recommended that groundwater projections for this site be rerun, with greater resolution, and that core samples be taken to determine the vertical profile of contamination. Should the dam be constructed, it would be prudent to establish a well at this site to monitor groundwater behavior.

318-11 (Wye Burial Ground)

Burial ground 318-11 is located somewhat more than a mile NE of Route 4 South and approximately 7 miles north of the 300 Area, adjacent to the WPPSS WNP-2 site. The projected groundwater level is 410 feet, about 5 feet below trench bottoms reported to be 15 feet below grade (BNWL, 1975), and 5 feet above the floor of the four caissons, 25 feet below grade. Because of the 1 arge inventory of both fission products and transuranics, it is recommended that transfer of radioisotopes to the environs be modeled under elevated groundwater conditions to determine whether decommissioning is required. The estimated cost for removal of contaminated materials from the four caissons and burial in 200 West is $\$ 470,000$ (assuming all materials require retrievable storage.

WBF -1 and $W B F-2$

These are storage facilities used by the PNL Ecosystems Department. Cost for removal of these buildings one-half mile to the reservoir shoreline and installation on new foundations is estimated to be $\$ 25,000$.

\section{SUMMARY OF SIGNIFICANT FINDINGS}

Construction of the proposed Ben Franklin Dam will result in adverse effects on approximately 65 radioactively contaminated facilities at Hanford. These include all facilities in the 100-F Area, all facilities excepting two 
burial grounds and a solar still at $100-\mathrm{H}$, and portions of the reactor effluent systems at 100-D, 100-K and 100-B. In addition, the caisson storage units at burial ground 318-11 may be affected by elevated groundwater levels. Whether this is a problem or not cannot be determined without modeling the transfer of radioisotopes from this site to the river under groundwater conditions accompanying the dam. Effects on the 116-N-1 crib and trench are not known at this time but should be investigated.

The extent of decommissioning activities in the 100 Areas required by the building of Ben Franklin Dam depends on a number of factors which could not be fully assessed in this study, including:

- the relative economics of decommissioning activities under present or post-Ben Franklin Dam (flooded) conditions

- the radioactive material release rates from retention basin systems and liquid and solid waste disposal facilities in the 100 Areas as affected by the proposed reservoir.

It is believed that decommissioning of $100-F$ and $H$ structures and radioactive waste sites is a prudent action based on several factors, including projected DOE plans for decommissioning surplus facilities; greater ease of decommissioning under non-flooded conditions; proper control of radioactive materials in existing facilities and in burial grounds; greater potential for public interaction with the Hanford Site due to the reservoir location and projected recreation areas; and the potential for a massive earth slide across the river from $100-\mathrm{F}$ and $100-\mathrm{H}$ Areas, and the resulting potential complications.

Decommissioning would include removal of all contaminated materials exceeding release criteria from all liquid waste disposal sites and burial sites at 100-F and 100-H except for two burial grounds at $100-\mathrm{H}$ except for two burial grounds at $100-\mathrm{H}$ which should be placed into protective storage. Release criteria have not yet been deter-mined for these facilities and will have to be established for specific facilities based on projected transport of radioisotopes to the river under reservoir conditions. Portions of the reactor effluent systems at $100-\mathrm{D}, 100-\mathrm{F}$ and $100-\mathrm{K}$ would be dismantled, including 
$100-\mathrm{F}$ and $100-\mathrm{K}$ would be dismantled, including removal of contaminated soil exceeding release criteria. Costs for accompiishing the work described above are estimated to be approximately $\$ 166,000,000$ (Table 26), (a) requiring a constant (1979) dollar budget of approximately $\$ 12,000,000$ annually over the 14-year construction period of the dam. Because of escalation, current dollar costs are almost certain to rise above this level.

These costs have been derived from estimates made in 1977, 1978 and 1979. 1977 dollars were escalated to 1978 dollars using an annual escalation rate of $10 \%$. 1978 costs were escalated to 1979 dollars using an annual escalation rate of $11 \%$.

Contingency factors are included in all estimates. Contingency factors used were approximately $25 \%$ for contaminated structures, $15 \%$ for noncontaminated structures and 15\% for liquid and solid waste disposal sites. Contingencies assigned to contaminated structures were those recommended by Vitro Engineering for the estimates made for decommissioning the $D$ Reactor complex. The lower contingency factor selected for liquid and solid waste disposal sites reflects the conservative assumption that 211 radioactive material exceeding background levels would be removed. In practice, it is likely that release criteria exceeding background will be established, which will substantially reduce the volume of radioactive material required to be removed for many liquid and solid waste disposal sites. The $15 \%$ contingency factor selected for noncontaminated structures is based on that commonly used for projects at the conceptual stage (Means 1978).

Table 26 is organized in order of certainty. Costs believed to be the most certain (reactors and ancillary facilities) are given in the left-hand cost column. Costs listed in the two columns to the right are believed to be progressively less certain for reasons discussed below.

Estimates compiled for reactor buildings and ancillary structures (excluding the retention basin structures) are believed to be within roughly

(a) Actual costs will probably be in the range of $\$ 100,000,000$ to $\$ 250,000,000$. 
TABLE 26. Summary of Decommissioning Costs Required to Accommodate Ben Franklin Dam, 1979 Dollars

\begin{tabular}{|c|c|c|c|c|}
\hline Area & $\begin{array}{c}\text { Reactors, Ancillary } \\
\text { Structures and } \\
\text { Miscellaneous Costs (a) }\end{array}$ & $\begin{array}{l}\text { Eff luent Dis- } \\
\text { charge System } \\
\text { Components } \\
\end{array}$ & $\begin{array}{c}\text { Removal of } \\
\text { Liquid and Solid } \\
\text { Waste Disposal Sites } \\
\text { Was }\end{array}$ & $\begin{array}{l}\text { Total for } \\
\text { Areas }(d)\end{array}$ \\
\hline $100-\mathrm{F}$ & $22,000,000$ & $4,400,000$ & $38,000,000$ & $65,000,000$ \\
\hline $100-\mathrm{H}$ & $21,000,000$ & $5,800,000$ & $24,000,000$ & $51,000,000$ \\
\hline $100-D$ & 150,000 & $3,400,000$ & $4,200,000$ & $7,700,000$ \\
\hline $100-N$ & 76,000 & -- & -- & 76,000 \\
\hline $100-K$ & -- & 140,000 & $22,000,000$ & $22,000,000$ \\
\hline $100-B$ & 440,000 & $14,000,000$ & $5,700,000$ & $20,000,000$ \\
\hline 600 & 25,000 & -- & 470,000 & 500,000 \\
\hline Totals & $44,000,000$ & $28,000,000$ & $94,000,000$ & $166,000,000(\mathrm{e}$ \\
\hline$\%$ & $27 \%$ & $17 \%$ & $57 \%$ & $100 \%$ \\
\hline
\end{tabular}

(a) Includes protective storage and fencing of effluent discharge system components and liquid and solid waste disposal sites.

(b) Excludes 107 Emergency Trenches.

(c) Includes 107 Emergency Trenches.

(d) Rounding errors may be present.

(e) Actual costs will probably be in the range of $\$ 100,000,000$ to $\$ 250,000,000$. 
$\pm 25 \%$ accuracy. These estimates are based on detailed cost estimates compiled by $V$ itro Engineering and reflect work on known quantities, i.e., buildings for which detailed construction drawings are available and for which the extent of radioactive contamination, if present, is reasonably well known.

Greater uncertainty should be attached to estimates for decommissioning reactor effluent discharge system components. During their operating lifetime these facilities experienced considerable leakage, resulting in contamination of substantial quantities of soil along the effluent piping and adjacent to the retention basins. Little information was available on the exterit of surrounding contamination at the time the cost estimates were made upon which the costs reported here were based and general assumptions were made on the volume of soil requiring removal. Since that time, additional information has become available (UNI 1978) on the extent of this contamination and for most instances, it appears to be greater than that which was assumed for the estimates, making the estimates optimistic. However, as for the liquid and solid waste disposal sites, no firm estimate of the amount of soil requiring removal can be made until release criteria are established for individual facilities.

Subject to the greatest uncertainty are estimates for removal of contaminated materials from liquid and solid waste disposal sites. Here the bulk of the costs are for excavation, packaging, transportation and reburial of contaminated material. These are largely volume-dependent costs, and the volume of material requiring removal will depend upon release criteria established for these facilities. Costs for decommissioning liquid waste disposal sites are based on the conservative assumption that all soil having measurable contamination exceeding background, as estimated in UNI 946 (UNI 1978) will be removed. Costs for decommissioning burial grounds are based on removal of the estimated volume of material buried at the site. It is believed that release criteria, when established, would be greater than the "measurable contamination" levels currently assumed for the liquid waste disposal sites and would also not encompass all materials deposited at the solid waste disposal sites. Actual volume of soil requiring removal would likely be less than the volumes employed in the estimates. Thus, the reported 
cost estimates for liquid and solid waste disposal site decommissioning should be considered as very tentative and somewhat conservative.

\section{RECOMMENDATIONS}

1. If the proposed dam is authorized, it is believed prudent that a program be implemented for decommissioning of affected Hanford facilities as described in this report. The estimated cost of this work was calculated to be $\$ 166,000,000^{(a)}$ as shown in Table 26. Actual costs probably range between $\$ 100,000,000$ and $\$ 250,000,000$. An annual budget of $\$ 12,000,000$ (1979) dollars would be required to accomplish this work in the 14-year period estimated to be required for dam construction.

2. Because there are major uncertainties in the cost estimated pertaining to waste disposal site and contaminated soil removal, it is recommended that the release potential and release criteria be established for all 100 Area retention basin systems and liquid and solid waste disposal facilities potentially affected by the proposed reservoir. The estimated cost of developing this information is $\$ 850,000$. Performing these studies will establish which facilities need to be removed and which can be left in place or protected by alternative means. A comprehensive characterization of most 100 Area effluent discharge system facilities and liquid waste disposal sites has been recently completed by United Nuclear Industries (UNI 1978); however, it is recommended that the following additional work be accomplished to support the establishment of release criteria:

- Determination of leaching characteristics of radioactive materials found at specific sites through analysis of existing samples if taken during the course of the UNI characterization program and through additional sampling where required.

- Radiological characterization of the 100 Area burial sites, the $116-\mathrm{N}-1$ trench and crib and the 100-F Animal Farm liquid and solid waste disposal sites $(116-F-9,118-F-5$ and $116-F-6)$. This characterization should include

(a) See footnote on p. 23. 
determination of the spatial extent of radioactive contamination, the physical characteristics of materials present in the burial sites, and the specific activities and leaching properties of radioisotopes present.

- Release criteria for specific facilities should be determined once sufficient characterization information becomes available. One approach to establishing release criteria requires modeling the release and transport of radioisotopes to the environment via air and water pathways and projection of dose to the maximum-exposed individual. The ratio of the projected dose to the allowable dose can then be used to determine the extent of decontamination required for the facility under consideration. This procedure is facility-specific, and must be accomplished for each facility potentially affected by elevated surface or groundwater levels.

- The techniques for determining dose to the maximum-exposed individual currently exist; however, agreement on the legitimacy of this approach and appropriate dose to the maximum-exposed individual does not. Prior to finäl determination of decommissioning requirements, Federal policy must be established on an acceptable method for determining release criteria.

3. The effect of the reservoir on functioning of potentially affected $100-\mathrm{N}$ facilities was not examined. Additional investigation into possible effects on operation of the facilities identified in Table 18 is recommended. The estimated cost of this task is about $\$ 60,000$.

4. It is recommended that the effects of elevated water levels on operation of the 1908-K outfall be assessed if it is anticipated that 100-K facilities would remain in standby status following completion of the dam. The estimated cost of this task is about $\$ 10,000$.

5. Removal of the 107-D retention basin and associated effluent piping is recommended because of the location of these facilities within 300 feet of the scarp that will form the reservoir shoreline at this point. The stability of the scarp under reservoir conditions should be assessed 
prior to final determination of appropriate decommissioning for 107-D.

The estimated cost of this assessment is about $\$ 10,000$.

6. Contaminated materials at 318-11 are below projected groundwater levels. Because of the large inventory of radioactive materials at this site, and the proximity of WPPSS Plant No. 2, more detailed modeling of anticipated groundwater levels is recommended prior to final determination of appropriate decommissioning for this facility. Installation of monitoring wells at $318-10$ and $318-11$ should be considered.

7. Because construction of the proposed reservoir may facilitate public use of the Hanford Reaches of the Columbia River, facilities having attractive nuisance potential should be removed or isolated. It is recommended that potentially hazardous facilities within approximately one mile of the shoreline, not recommended for removal and not currently enclosed by security fencing, be enclosed by industrial-quality security fencing. The cost of this work is estimated to be $\$ 400,000$. 


\section{REFERENCES}

Battelle, Pacific Northwest Laboratories. 1975. Resource Book, Disposition of Retired Contaminated Facilities at Hanford. BNWL-MA-28, Battelle, Pacific Northwest Laboratories, Richiland, WA.

United Nuclear Industries, Inc. 1978. Radiological Characterization of the Retired 100 Areas. UNI-946, United Nuclear Industries, Richland, WA.

J. W. Ballowe. 1967. Ben Franklin Dam Study Final Report - I. DUN-2349, Douglas United Nuclear, Richland, WA.

U.S. Army Corps of Engineers (Ben Franklin Dam Study) Vol. I, 1969.

Cline, J. F., G. M. Holter, W. H. Rickard and E. L. Klepper. 1976. Experimental Design for Demonstration of Biobarriers $P$ laced in Simulated Burial Trench. BNWL-2035, Battelle, Pacific Northwest Laboratories, Richland, WA.

Mearis, R. S. 1978. Building Construction Cost Data, 1979. R. S. Means Co., Duxbury, MA.

Department of Energy. 1978. Preliminary Plan for Decommissioning of Department of Energy Radioactively Contaminated Surplus Facilities. HCP/P0701-01, Assistant Secreatary for Environment, Division of Environmenta? Control Technology. 


\section{TASK 6: HYDROTHERMAL ANALYSIS ${ }^{(a)}$}

\section{PROBLEM STATEMENT}

Construction of the proposed Ben Franklin Dam will add another run-ofthe-river impoundment to the Columbia River system. Such impoundments are characterized by low head dams with reservoirs extending just beyond the boundaries of the natural channel, and water detention times of a few days to a week. Under average streamflow conditions $(121,000 \mathrm{cfs})$ and with a 400-foot MSL pool elevation, Ben Franklin Dam would increase the flow travel time by a factor of four over present conditions and almost double the surface area of the Hanford Reach. Largely because of these changes in the hydraulic characteristics of the reach, the thermal characteristics will also be altered. A 1976 report on Columbia River water temperatures by Hydrocomp, Inc., pointed out that the thermal effects of run-of-the-river impoundments were studied by J. M. Raphael. According to the Hydrocomp study, Raphael concluded that, on the average, Wanapum and Priest Rapids Dams would cause a $0.8^{\circ} \mathrm{C}$ increase during the month of August, and Wells and Rocky Reach Dams would cause a $1.1^{\circ} \mathrm{C}$ increase during the same month.

In addition to affecting water temperatures, alterations in the hydraulic regime would also impact the thermal assimilative capacity of the Hanford Reach. Existing and past heated discharges to the Columbia River have experienced rapid initial mixing due to intense vertical mixing. Initial mixing can be affected either by river or reservoir turbulence levels or by the design of the discharge diffuser. Turbulence in the reservoir is expected to be significantly reduced from natural levels under low river flow conditions but will be far less affected at moderate and high river flows. The mixing characteristics of the Hanford Reach may be further altered by vertical thermal stratification, which acts to inhibit the movement of effluent plumes to the water surface.

Changes in thermal regime and mixing characteristics induced by dam construction are of importance primarily because of the potential for future

(a) L. D. Kannberg and S. M. Brown 
competition between Ben Franklin Dam and thermal power plant development at Hanford for the remaining thermal carrying capacity of the Harford Reach. The thermal carrying capacity of the Columbia River between Priest Rapids Dam (river mile 397) and the Oregon-Washington border (river mile 309) has been defined in terms of a water temperature standard. Simply stated, this standard does not allow water temperatures to exceed $20^{\circ} \mathrm{C}\left(68^{\circ} \mathrm{F}\right)$ as a result of human activities. In addition, no temperature increase will be allowed which will raise the receiving water temperature by greater than $0.3^{\circ} \mathrm{C}\left(0.5^{\circ} \mathrm{F}\right)$ when natural temperatures exceed $20^{\circ} \mathrm{C}$ (Washington State Department of Ecology 1977). This standard was, in part, established to protect anadromous fish; their lethal threshold has been estimated to be $21^{\circ} \mathrm{C}\left(69.8^{\circ} \mathrm{F}\right)$ (Hydrocomb, Inc., 1976). Under extreme low flow conditions and summer meteorological conditions, the $20^{\circ} \mathrm{C}$ standard can be exceeded naturally both in and downstream of the Hanford Reach. In order to preclude standard violations, the operating schedule of $\mathrm{N}$-Reactor and the Hanford Generating Plant (HGP) have had to be modified at times.

Pacific Northwest Laboratory recently investigated the concept of a nuclear energy center at Hanford (PNL 1978). This investigation found that under the large-scale energy development scenario considered, proper heat sink management, including the use of the Columbia River for once-through cooling of six reactors, could be achieved. The construction of Ben Franklin Dam could limit or even preclude the development of a Hanford Nuclear Energy Center (HNEC), however, by decreasing the thermal carrying capacity of the Hanford Reach. Dam construction could also have an impact on reactor operations and potentially require the use of closed cycle cooling systems on all new power plants. The resulting environmental consequences are increased cloudiness, ground-level humidity and fog, and decreased solar radiation.

The objectives of the Task 6 Hydrothermal Analysis are twofold. The first is to evaluate what impact the Ben Franklin Dam reservoir would have on the water temperature of the Hanford Reach and its capacity for thermal assimilation. The second objective is to determine the impact of Ben Franklin Dam on the developmert of a HNEC. 


\section{SCOPE OF INVESTIGATIONS}

To meet the previously stated objectives, two hydrothermal investigations were performed. The first was directed at a large-scale evaluation of the Hanford Reach under both natural river conditions and with the Ben Franklin Dam. This investigation involved the use of a mathematical model to predict river water temperature. In addition to assessing the temperature effects of the dam, the effects of proposed HNEC heated discharges both with and without the dam were also evaluated. The second investigation was directed toward determining what impact alterations in hydraulic characteristics would have on the near-field mixing of heated effluents discharged to the Hanford Reach. An investigation of this type makes it possible to estimate how the thermal assimilative capacity of the reach would be impacted by the construction of Ben Franklin Dam.

\section{Water Temperature Investigation}

The complexities inherent in the scientific study of river systems, coupled with the need for quantitative description of water quality behavior, have created great interest in mathematical models as tools for simulating the response of a river system to alternative planning and management proposals. The COLHEAT River Simulation Model is one such tool that was developed in the mid-60s to evaluate potential modifications in the thermal regime of the Columbia River as a result of heated discharges from power plants and dam construction and operation. COLHEAT has been tested and verified against water temperature measurements taken at numerous Columbia River locations since 1966 (Hanford Engineering Development Laboratory 1972). COLHEAT has also been used to evaluate power plant siting on many of the major river basins in the United States, including the Mississippi River (Dragnich, Myhres and Jaske 1974).

The COLHEAT model employs a control volume approach to river modeling. Parcels of water are transported through individual river reaches. The temperature of each parcel is modified according to the effect of meteorological conditions, the temperature of water flowing into the reach and heated effluents discharged to the reach. River reaches are represented in the model as "troughs" which approximate the characteristics of the natural system. 
Typically, the water surface area of the natural system and model system are kept the same because most of the heat transfer occurs at the air-water interface. Data are input to the model on a daily basis. These data include water temperatures and streamflows at the upstream end of the study reach and meteorological data (i.e., wind velocity, mean air temperature, dew point, sky cover, incoming short wave radiation).

To evaluate the water temperature impacts of Ben Franklin Dam and a HNEC, both separately and in combination, the COLHEAT model was applied to the Hanford Reach. COLHEAT was used on one other occasion by Jaske (1968) to obtain a preliminary estimate of the thermal effects of the dam. Jaske evaluated water temperature changes for reservoir elevations of 385 feet MSL anc 400 feet MSL and concluded that Ben Franklin Dam "... would have a nominal effect, tending towards a slight increase in downstream temperatures..." He further concluded that during periods of rising air temperature, clear skies, and high solar radiation (from April to November), thermal stratification could occur with the 400-foot pool. However, the probability that this condition would occur or persist was not estimated.

The river reach selected for the water temperature investigation reported herein extended from just downstream of Priest Rapids Dam (river mile 396.6) to the upstream end of the reservoir formed by McNary Dam, Lake Wallula, (river mile 338.0). This portion of the Columbia River is commonly referred to as the Hanford Reach; it is the last free-flowing section of the river in the United States.

Figure 22 shows how water surface elevations vary with streamflow for both natural river conditions and the 400-foot pool created by Ben Franklin Dam. The water surface elevation data for natural conditions were obtained from a collection of hydrographic information pertinent to the Hanford Works (Wood 1954). These data compare quite well (within about 2 feet) with the U.S. Army Corps of Engineers data used to calibrate the physical models of the Hanford Reach (Copp 1967; Ballowe 1967). At the request of Douglas United Nuclear, Inc., these models were coristructed to evaluate the degree of interference between heated discharges and downstream cooling water intakes 


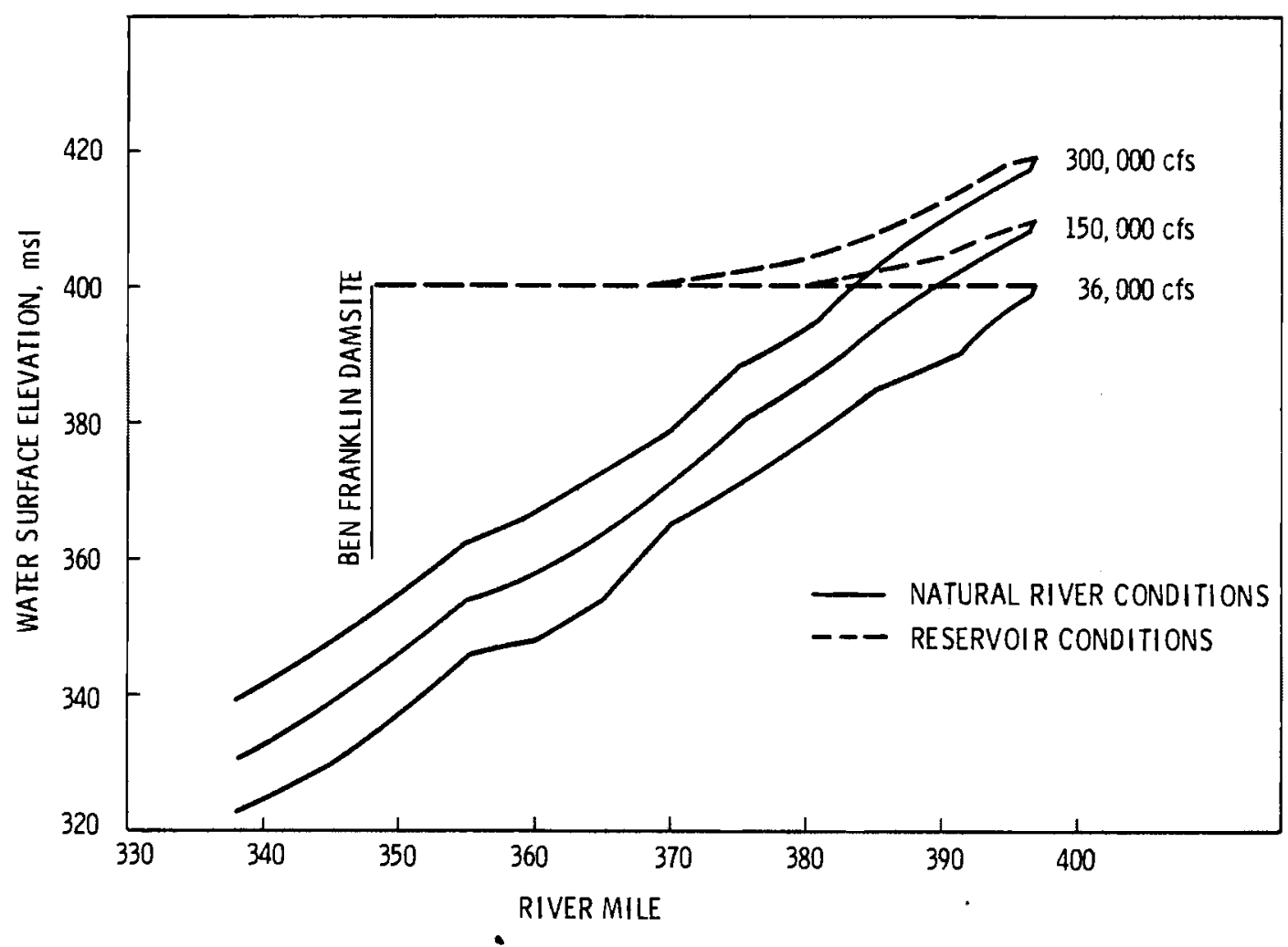

FIGURE 22. Natural River and Reservoir (400-ft MSL P0o1) Water Surface Elevation Changes Under Different Flow Conditions

(in the 100 Areas) caused by the Ben Franklin Dam. Data on the water surface elevations which would exist under reservoir conditions were taken from information supplied by the Seattle District, U.S. Army Corps of Engineers.

The Hanford Reach was subdivided into 28 model reaches, each approximately 2 miles in length. Detailed cross section data obtained from the Seattle District, U.S. Army Corps of Engineers and the water surface profile data shown in Figure 22 were used to estimate the width of each reach for both natural and reservoir conditions. The cross section data were also used to determine other channel characteristics, such as cross-sectional area and depth, for use in modeling.

COLHEAT requires modeling the daily streamflow and water temperature data at the most upstream location in the system, as well as daily meteorological data for input. Under contract to the Department of Energy, Pacific Northwest Laboratory has been compiling these data for selected locations along the 
Columbia River since 1966. Streamflow and water temperature data from Vernita, and Hanford weather data, for the calendar year 1975 were selected for this analysis. The 1975 data were selected because streamflows during the summer months were relatively low; such streamf low conditions are best for examining the water temperature impact of reservoir construction and the potential for thermal stratification. Because the results of this analysis were also to be used in Task 7, Meteorological Effects, for assessing potential changes in the probability of fog occurrence, 1975 was also selected because it represented reasonable winter weather conditions.

To ensure that the COLHEAT model was operating properly, the 1975 data were input to the model along with data on the operation of $\mathrm{N}$-Reactor (including HGP). These were the only major sources of artificial heat input to the Hanford Reach during that year. Simulated water temperatures were compared with measured data from the Richland thermograph and satisfactory agreement was obtained.

Following the testing of COLHEAT, 1-year water temperature simulations were made using the 1975 streamflows, temperatures and weather conditions as a base. Four aases were simulated:

- Case 1 - Natural river conditions with no discharge of heated effluents.

- Case 2 - Reservoir conditions (i.e., Ben Franklin Dam with a 400-foot MSL pool) with no discharge of heated effluents.

- Case 3 - Natural river conditions with proposed HNEC discharges.

- Case 4 - Reservoir conditions with proposed HNEC discharges.

The HNEC was assumed to be composed of five clusters of nuclear reactors with each cluster containing four power plants. It was further assumed that one of the clusters contained two once-through cooled plants and the other clusters each had one once-through plant. All other reactors had closed cycle cooling systems. The total daily heat release to the river from each once-through system was estimated to be $2500 \mathrm{MWt}$ (see the Near Field Dilution of HNEC Effluent Plumes section for details). Blowdown releases from the closed cycle systems were included in this estimate. The heated effluents from the once-through reactors and the closed-cycle system blowdowns were 
discharged into the model reach in closest proximity to the proposed location of each cluster; these locations were at river miles $386.7,384.7,382.1$, 380.1 and 362.5. To account for refueling and maintenance operations, two of the six once-through reactors were shut down for a month during July, August and September. The above assumptions are consistent with those made during the assessment of the HNEC concept (PNL 1978).

The results of the four simulation cases are shown graphically in Figures 23 and 24. Figure 23 presents a comparison of water temperatures at Richland (river mile 338.0) with and without Ben Franklin Dam (i.e., Cases 1 and 2). In general, these results show that, for hydrologic and meteorologic conditions similar to those in 1975, Ben Franklin Dam would have a small impact on water temperatures, particularly during the period of October through March. As Table 27 shows, the maximum increase in average monthly water temperatures is $0.4^{\circ} \mathrm{C}\left(0.7^{\circ} \mathrm{F}\right)$. While the $20^{\circ} \mathrm{C}$ water temperature standard was not exceeded by the construction of Ben Franklin Dam, there is a potential for violation under more critical streamflow or weather conditions than those which occurred in 1975. The inclusion of N-Reactor (and HGP) discharges would also increase the probability that the standard would be exceeded under reservoir conditions.

An examination of both Figure 24 and Table 27 indicates that HNEC discharges without the construction of Ben Franklin Dam (Case 3 ) would produce approximately a $1.0^{\circ} \mathrm{C}\left(1.8^{\circ} \mathrm{F}\right)$ increase in water temperatures throughout the year. In addition, the $20^{\circ} \mathrm{C}$ standard is violated several times during the summer months. The addition of Ben Franklin Dam to the HNEC scenario (Case 4 ) results in slightly increased average monthly temperatures during the period of March through August. The water temperature standard is still exceeded for this case, although the violations occur less frequently due to the dampening effect of the reservoir on temperature transients. While this dampening effect tends to reduce the frequency of violations, it also tends to extend the duration of each violation.

Under conditions of extreme low flows and high solar radiation input, it may be possible for the reservoir created by Ben Franklin Dam to thermally stratify. In addition to inhibiting the movement of heated effluents to the 


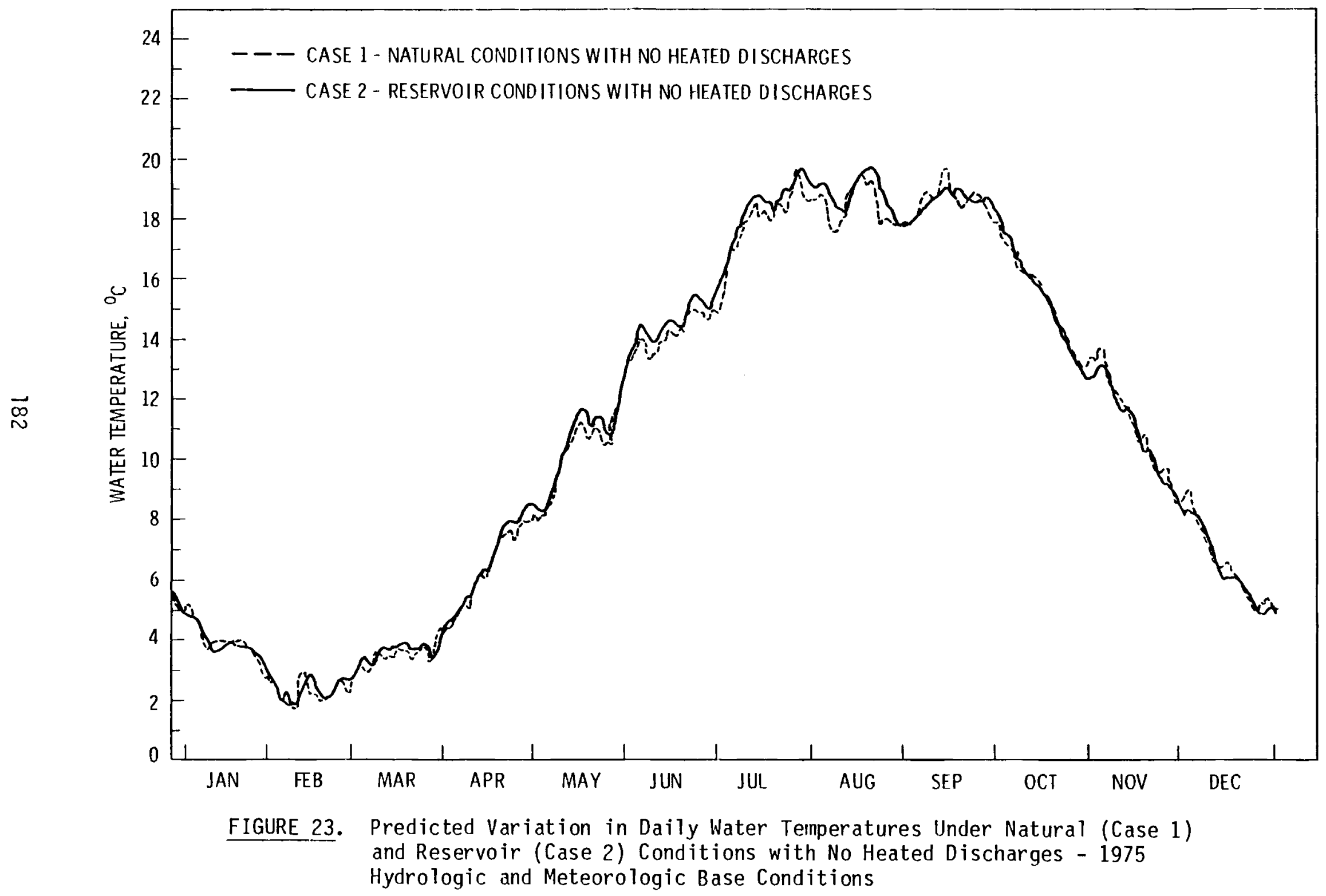




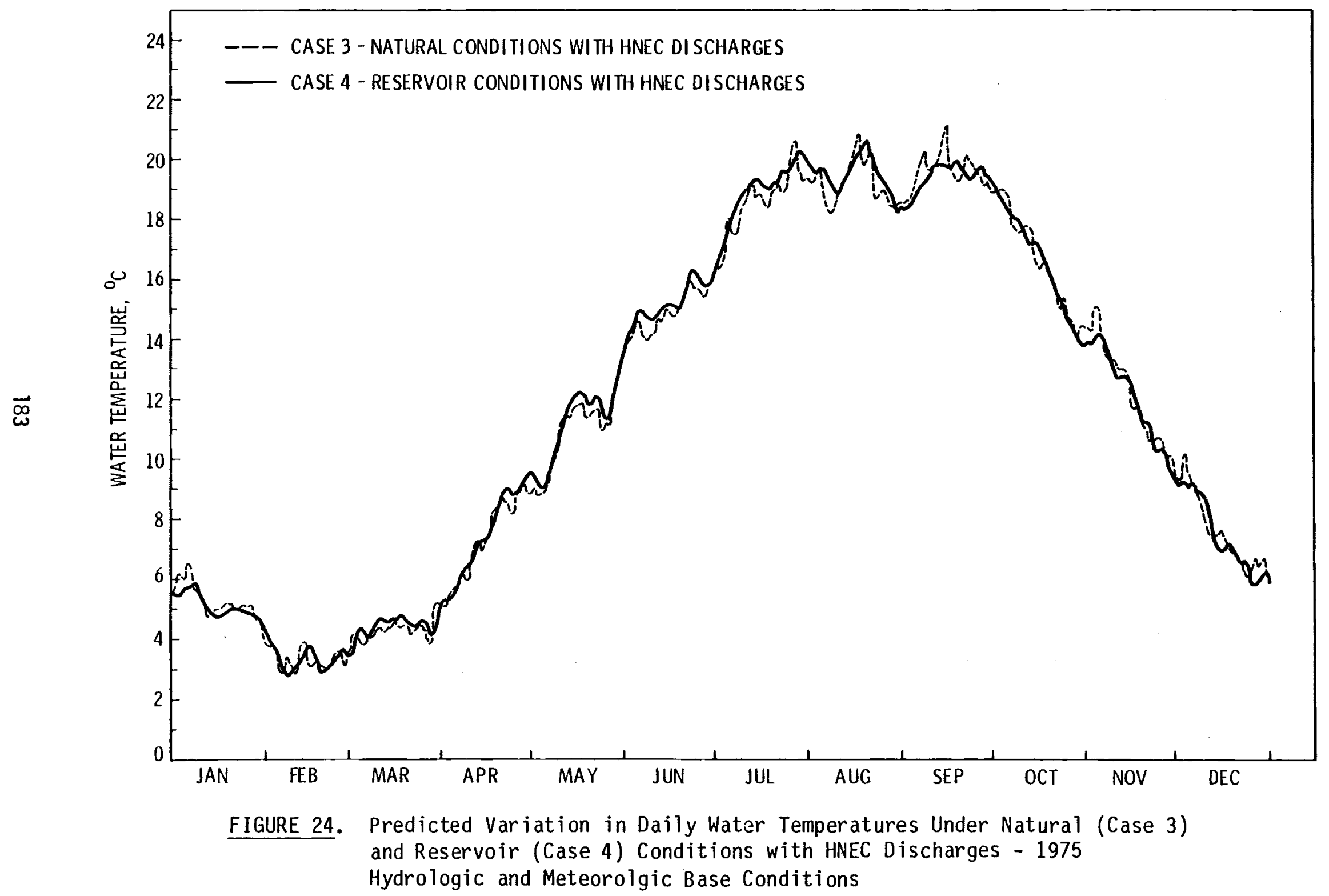


TABLE 27. Predicted Average Monthly Water Temperatures at Richland for Each Case

\begin{tabular}{|c|c|c|c|c|}
\hline Month & Case 1 & Case 2 & Case 3 & C.ase 4 \\
\hline January & 4.2 & 4.1 & 5.3 & 5.1 \\
\hline February & 2.3 & 2.4 & 3.3 & 3.3 \\
\hline March & 3.5 & 3.6 & 4.4 & 4.5 \\
\hline April & 6.4 & 6.6 & 7.4 & 7.5 \\
\hline May & 10.3 & 10.6 & 11.1 & 11.3 \\
\hline June & 14.2 & 14.6 & 15.0 & 15.2 \\
\hline JuTy & 18.0 & 18.3 & 18.6 & 18.9 \\
\hline August & 18.4 & 18.8 & 19.2 & 19.5 \\
\hline September & 18.6 & 18.6 & 19.6 & 19.4 \\
\hline October & 15.3 & 15.3 & 16.7 & 16.5 \\
\hline November & 11.1 & 10.6 & 12.2 & 12.0 \\
\hline December & 6.4 & 6.4 & 7.5 & 7.4 \\
\hline
\end{tabular}

water surface, thermal stratification, if strong enough, can isolate colder, denser waters on the bottom and preclude vertical mixing. As a result, surface waters in the reservoir would become warmer and bottom waters may experience water quality degradation (e.g., reduced dissolved oxygen concentrations or nutrient cycling). The J.S. Army Corps of Engineers design studi (1969) for the Ben Franklin Dam points out that the reservoir is expected to be completely mixed downstream of river mile 375 . Upstream of this location the potential for thermal stratification would increase under reservoir conditions; this conclusion was made at the same time that six of the nine Hanford reactors were in operation. While it is clear that the potential for stratification exists, it was not possible to estimate the probability of its occurrence in this investigation. As Jaske (1968) pointed out ..."A detailed examination of data compiled over several years would be required to draw meaningful conclusions" (about the potential for thermal stratification). 
Near Field Dilution of HNEC Effluent Plumes

It is postulated that the Columbia River could assimilate the waste heat from six once-through cooled 1250-MWe nuclear power plants without causing significant environmental harm (PNL 1978). The analysis presented herein examines the effect of Ben Franklin Dam on probable mixing in the immediate region of one typical once-through discharge from an HNEC power plant. Site-specific considerations will affect the accuracy of thermal plume analyses. However, since the HNEC is only conceptual at this time and no specific once-through cooled power plant sites have been selected, the analysis will employ site characteristics typical of the region between river mile 370 and river mile 390 for the analysis.

It is assumed that the nuclear power plant produces 1250 MWe at $33 \%$ thermodynamic efficiency resulting in a waste heat discharge of $2500 \mathrm{MWt}$ to the river. The temperature rise across the condenser is taken to be $11.1^{\circ} \mathrm{C}\left(20^{\circ} \mathrm{F}\right)$ resulting in a cooling water flow rate of $1971 \mathrm{cfs}$. The discharge system is assumed to be a multiple port discharge having 100 ports of 1.5 feet $(0.46 \mathrm{~m})$ diameter spaced every 3.75 feet $(1.14 \mathrm{~m})$. The ports are elevated 5 feet off the bottom and discharged with the current at an angle of $20^{\circ}$ from the horizontal. The multiple port discharge line is assumed to be located at river mile 380 (near the present Hanford Generating Plant discharge).

The analys is will be taken from work performed by Kannberg and Davis (1976). Their work involved both experimental and analytical investigation of multiple port discharges. The results of the experimental work will be employed. For discharges similar to the one of issue here they developed regression curve fits of the form

$$
\frac{\Delta T_{c}}{\Delta T_{0}}=e^{a}\left(\frac{L}{D}\right)^{b}(\theta)^{c}(F)^{d}(R)^{e}\left(\frac{x}{D}\right)^{f}
$$


where

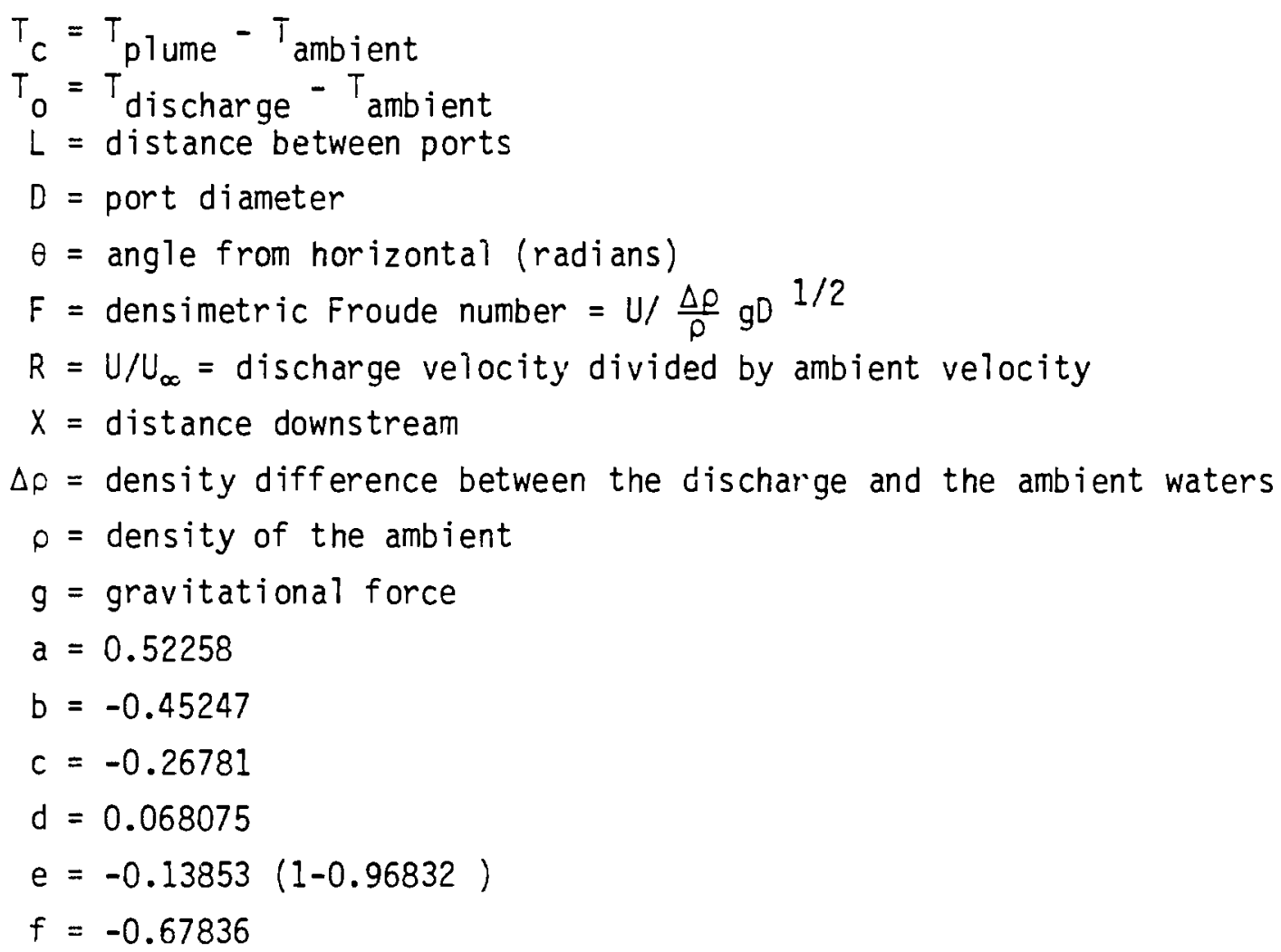

and ambient refers to the river.

For the conditions outlined earlier, and an ambient river temperature of $15.6^{\circ} \mathrm{C}\left(60^{\circ} \mathrm{F}\right)$ the following values can be computed:

$$
\begin{aligned}
& \frac{L}{D}=2.5 \\
& U=11.2 \mathrm{ft} / \mathrm{s}(3.4 \mathrm{~m} / \mathrm{s}) \\
& \theta=0.35, \text { and } \\
& F=32.6
\end{aligned}
$$


The remaining value required for determining the downstream temperature decay is the river velocity. Based on cross section flow area, mean river flow velocities for this reach have been computed to be $3.7 \mathrm{ft} / \mathrm{sec}(1.1 \mathrm{~m} / \mathrm{s})$ for natural conditions and $2.2 \mathrm{ft} / \mathrm{sec}(0.67 \mathrm{~m} / \mathrm{s})$ for the reservoir conditions and a flow of $121,000 \mathrm{cfs}$. Since it is likely that the outfall would be located in the fastest moving portion of the river, the river velocities would likely be considerably larger. Available data indicate that under natural conditions the velocity in this location is about $5.0 \mathrm{ft} / \mathrm{sec}(1.5 \mathrm{~m} / \mathrm{s})$ at mid-depth. Employing the ratio 5.0/3.7 to determine the velocity under reservoir conditions gives a main stream velocity of $3.0 \mathrm{ft} / \mathrm{sec}(0.9 \mathrm{~m} / \mathrm{s})$. The $R$ values for the natural and reservoir conditions are 0.44 and 0.27 for main stream flow, respectively.

The equation for excess temperature provided earlier can now be used to estimate dilution downstream for the natural and reservoir conditions for a river flow of 121,000 cfs (the annual average). These results are presented in Table 28. These results indicate that under normal conditions the HNEC outfalls will meet state standards during periods of river temperatures less than $20^{\circ} \mathrm{C}\left(68^{\circ} \mathrm{F}\right)$. This will be true regardless of the reservoir, provided high dilution multiple port outfalls are employed.

Additional analyses similar to the one above for low river flow periods would be required to complete this investigation. However, mixing at these flows is heavily dependent on site-specific considerations. Joint operation of both Priest Rapids and Ben Franklin Dam will likely have a large impact on flow and mixing in the reservoir, particularly at low flow. In order to avoid biasing these more detailed analyses, an analysis under such low flow conditions is not offered here. Analysis of superposition of successive HNEC thermal effluent plumes may also be a legitimate topic for concern. Again, site-specific factors rule out suitable analysis of this issue. 


\begin{tabular}{|c|c|c|}
\hline $\begin{array}{l}\text { Downstream } \\
\text { Distance } m(\mathrm{ft})\end{array}$ & $\begin{array}{r}\text { Natural } \\
\text { TC OC }\end{array}$ & $\begin{array}{l}\text { Reservoir } \\
\text { Tc oc } \\
\end{array}$ \\
\hline $6.1(20)$ & 3.9 & 4.1 \\
\hline $9.1(30)$ & 2.9 & 3.1 \\
\hline $12.2(40)$ & 2.4 & 2.5 \\
\hline $15.2(50)$ & 2.1 & 2.2 \\
\hline $18.3(60)$ & 1.8 & 1.9 \\
\hline $21.3(70)$ & 1.7 & 1.7 \\
\hline $24.4(80)$ & 1.5 & 1.6 \\
\hline $27.4(90)$ & 1.4 & 1.4 \\
\hline $30.5(100)$ & 1.3 & 1.3 \\
\hline $33.5(110)$ & 1.2 & 1.3 \\
\hline $36.6(120)$ & 1.2 & 1.2 \\
\hline $39.6(130)$ & 1.1 & 1.1 \\
\hline $42.7(140)$ & 1.1 & 1.1 \\
\hline $45.7(150)$ & 1.0 & 1.1 \\
\hline
\end{tabular}

\section{SIGNIFICANT FINDINGS}

The following conclusions can be drawn as a result of the investigations performed in this task:

1. Under relatively low streamflow conditions, normal meteorological conditions and current Columbia River system operations (similar to those which occurred in 1975), construction of the proposed Ben Franklin Dam will result in an increase in water temperatures over natural conditions of approximate $1 y 0.4^{\circ} \mathrm{C}\left(0.7^{\circ} \mathrm{F}\right)$ in summer and $0.1^{\circ} \mathrm{C}\left(0.2^{\circ} \mathrm{F}\right)$ or less in winter. Under more extreme meteorological and streamflow conditions, water temperatures may exceed the $20^{\circ} \mathrm{C}\left(68^{\circ} \mathrm{F}\right)$ Washington State standard for the Hanford Reach.

2. The development of an HNEC with six once-through cooled nuclear reactors and 14 closed-cycle system reactors discharging a total thermal load 
of 15,000 MWt would raise water temperatures by approximately $1^{\circ} \mathrm{C}$ $\left(1.8^{\circ} \mathrm{F}\right)$ throughout the year. Under the hydrologic and meteorologic conditions studied (calendar year 1975), the temperature standard would be violated frequently during summer months.

3. The combined effect of HNEC thermal discharges and the Ben Franklin Dam is an increase in average water temperatures during the period of March through August over natural conditions with HNEC discharges and an increase in the duration of water temperature standard violations.

4. While the occurrence of vertical thermal stratification in the reservoir created by Ben Franklin Dam is not highly likely, such conditions are possible and could exacerbate water temperature problems as well as create other water quality problems. Within the scope of the work performed, the probability of occurrence for thermal stratification was not quantified.

5. Near-field mixing of HNEC reactor effluents is rapid when high initial dilution multiple port diffusers are employed. Employing such a diffuser results in downstream temperatures which vary little during average flow conditions. State standards would likely be satisfied under those conditions for either natural or reservoir flows.

6. Site-specific issues will dominate mixing at lower river flows, making effluent dilution assessments difficult. Superposition of successive reactor discharge thermal fields could influence local satisfaction of state water quality thermal standards. Again, site-specific factors create severe problems for assessment of this issue.

\section{RECOMMENDATIONS}

The hydrothermal investigations conducted as part of this study indicate that, because of the limited thermal carrying capacity of the Hanford Reach, 1 arge-scale energy development on the order of a nuclear energy center at Hanford would be impacted by the construction of Ben Franklin Dam; this conclusion assumes that once-through cooling is a viable alternative for at least 
a certain percentage of the HNEC reactors. Because this potentially creates a competitive situation between these two energy developments, it is recommended that a study be performed to identify the costs and benefits of dam construction with respect to this matter. Such a study would be useful in identifying the optimal level of energy development and heat sink management possible in light of the Washington State water temperature standard. It is estimated that a study of this type would be on the order of $\$ 50,000$ to $\$ 100,000$.

Detailed studies related to thermal stratification, low flow effluent mixing and superposition of effluent plumes are also recommended. However, these studies are probably better addressed during preparation of the environmental report on Ben Franklin Dam or during analyses for preparation of the environmental report or environmental statement on the HNEC.

\section{REFERENCES}

Ballowe, J. W. 1967. Ben Frankl in Dam Study, Final Report - I, DUN-2349, Douglas United Nuclear, Inc., Richland, WA.

Copp, H. D. 1967. Final Report on Thermai-Hydraulic Pilot Models of the Columbia River. Research Report No. 67/9-67, DUN-WSU-3, ColTege of

Engineering, Research Division, Washington State University, Pullman, WA.

Dragnich, D. W., A. S. Myres and R. T. Jaske. 1974. Assessment of Lower Mississippi River Thermal Capacity, Phase I. Prepared for Middle South Services, Inc., New Orleans, LA, by BattelTe, Pacific Northwest Laboratories, Richl and, WA.

Hanford Engineering Development Laboratory. 1972. The COLHEAT River Simulation Model. Richl and, WA, HEDL-TME 72-103.

Jaske, R. T. 1966. "Evaluation of Columbia River Cooling Program." The Use of Simulation in Water Research. Oregon State University, Water Resources Research Institute, Corvaltís, OR.

Jaske, R. T. 1968. A Preliminary Evaluation of the Thermal Effects of the Ben Franklin Dam Project on Columbia River Temperatures Below the hanford Plant. BNWL-733, BatteTle, Pacific Northwest Laboratories.

Kannberg, L. D., and L. R. Davis. 1976. An Experimental-Analytical Investigation of Deep Submerged Multiple Buoyant Jets. EPA Report 600/3-76-101, September 1976. 
The Hanford Nuclear Energy Center: A Conceptual Study. 1978. PNL-2640, Pacific Northwest Laboratory, Richland, WA 99352

Report on Columbia River Water Temperature Study. 1976. Prepared by Hydrocomp, Inc., Palo Alto, CA for the U.S. Army Corps of Engineers, North Pacific Division, Contract No. DACW 57-75-C-0304.

U.S. Army Corps of Engineers, Seattle District. 1969. Ben Franklin Lock, Dam and Reservoir, Volumes 1 and 2.

Water Quality Planning, Office of Water Programs. 1977. Washington State Water Quality Standards. Department of Ecology, Olympia, WA.

Wood, V. W. A Summary of Columbia River Hydrographic Information Pertinent to Hanford Works, 1894 to 1954. 1954. General Electric Company, Hanford Atomic Products Operation, Richland, WA 99352. 
$\therefore$

i

$+$

, ) 


\section{TASK 7: METEOROLOGICAL EFFECTS}

The construction and operation of Ben Franklin Dam might result in effects involving meteorological processes. One potential effect of the dam reservoir could be an increase in the incidence of fogging and icing on the Hanford Site. Previous studies on the Hanford Nuclear Energy Center concept had shown that cooling ponds resulted in unacceptable increases in hours and density of fog. A dam reservoir which accepts waste heat discharges from thermal plants would tend to resemble a cooling pond.

A second potential effect could be increased radiation doses to workers and the general public from the excavation and subsequent airborne transport of radioactive materials. The source of such radioactive materials would be existing burial grounds or contaminated soils requiring removal because of flooding caused by the Ben Franklin Dam reservoir or an increased water table.

WEATHER EFFECTS $^{(a)}$

Problem Statement

The proposed Ben Franklin Dam and reservoir may increase the incidence of fogging and icing on Hanford operations and the surrounding area. Potential areas of concern include:

- fog and ice affecting highway transportation

- ice on power transmission lines

- fog affecting visibility at observatory

- fog restricting commercial air traffic.

A worst case is studied with heat input to the Columbia River from a Hanford Nuclear Energy Center described in Task 6, Hydrothermal Analysis.

(a) S. L. UTanski 
Scope of Investigation

Two areas were investigated:

1. The frequency and severity of fog and icing occurring over the Hanford Site.

2. Evaporation from the reservoir behind the dam and its potential effect on (1).

Climatological statistics compiled by Woodruff et al. (1971) point out that greater than 90 percent of the occurrence of fog is during the winter months; obviously, icing is also confined to this period. For this reason, this study is limited to assessing meteorological effects during the winter months. For a 25-year period, Woodruff determined that the average annual number of days of $\mathrm{fog}$ is 38 for the Hanford Meteorological Station (HMS) and 20 for Richland. Nocturnal cooling (radiation) fog is the most prevalent type of fog occurring both at Hanford and in the Tri-Cities. There are occasional occurrences of steam fog from the Columbia River, but these are not usually deep. Although dense fog (visibility less than $1 / 4$ mile) comprises approximately 60 percent of all fogs observed at HMS, it is not very persistent, usually lasting no longer than 3 hours. The average frequency of icing was 20 and 23 days per year at Richland and HMS, respectively.

Woodruff et al. concluded that both fogging and icing have relatively little effect on operations within the Hanford area. Airport and observatory activities are minimally disrupted. Power line icing and roadway fog is localized.

Studies of the potential impact of cooling towers at proposed nuclear power plants at Hanford indicate the potential for fogging and icing impacts at Hanford. Woodruff (1971) and Droppo et al. (1976) indicate little effect on Hanford operations from natural draft and mechanical draft cooling towers. In particular, they predict minimal disruption of activities at the local airports and at the observatory on top of Rattlesnake Mountain. Power line icing and roadway fog is predicted to be infrequent and localized. 


\section{Significant Findings}

Results from the COLHEAT model show that the winter average evaporation flux for a stretch of the Columbia River extending from approximately WNP-2 to the Priest Rapids Dam is $19.3 \mathrm{Btu} / \mathrm{ft}^{2} /$ day. For a similar river length, the evaporation flux with a Ben Franklin Dam is calculated to be $33.5 \mathrm{Btu} / \mathrm{ft}^{2} / \mathrm{day}_{\text {, }}$ almost double that without the dam. This increase in evaporation flux is primarily the result of increasing the temperature of the impounded water. Jaske (1968) points out that the dam's effect is to increase the annual average temperature of the reservoir by 0.4 to $0.6^{\circ} \mathrm{C}$.

With the existence of the dam, the surface area of the water is increased from $6.2 \times 10^{8} \mathrm{ft}^{2}$ to $11.7 \times 10^{8} \mathrm{ft}^{2}$. Using these surface areas, the average amount of moisture evaporated during a winter day is $1.2 \times 10^{11} \mathrm{~g}$ and $3.8 \times 10^{11} \mathrm{~g}$ for the free flowing and dammed river, respectively. To place these numbers in perspective, they correspond to the amount of moisture concentrated in a medium-sized thunderstorm (Ulanski and Garstang 1978). Because the evaporation occurs over more than 60 miles of river, the moisture will be reiatively well dispersed so as not to significantly alter the meteorological regime over the Hanford Site, although the evaporation for the impounded water is three times larger than for natural conditions.

With strong winter inversions predominating over the valley to inhibit vertical diffusion of the moisture and light winds characteristic of radiation fogs, the effect of the increased moisture would probably be a localized increase in the thickness and duration of the fog.

As a result of this analysis, it is concluded that the proposed Ben Franklin Dam will have minimal effect on altering the meteorological conditions (fogging, icing) and, in turn, disrupting activity on the Hanford Site.

However, a potential problem not analyzed is the effect of the increased moisture on the indigenous plant species. Areas of concern are increased dew and its relationship to vegetative growth and/or alteration. 


\section{REFERENCES}

Droppo, J. G., C. E. Hane and R. K. Woodruff. 1976. Atmospheric Effects of Circular Mechanical Draft Cooling Towers at Washington Public Power Supply System Nuclear Power Plant Number Two. Contract B 2311200735, BattelTe, Pacific Northwest Laboratories, Richland, WA 99352. Report to

Burns \& Roe, Inc., Hempstead NY.

Jaske, R. T. 1968. A Preliminary Evaluation of the Thermal Effects of the Ben Frank I in Dam Project on Columbia River Temperatures Below the Hanford Plant. BNWL-733, Pacific Northwest Laboratory, Richland, WA 99352.

Ulansiki, S. L., and M. Garstang. 1978. "The Role of Surface Divergence and Vorticity in the Life Cycle of Convective Rainfall. Part I: Observations and Analysis. J.Atmos. Sci. 35: 1047-1062.

woodruff, R. K., D. E. Jenne, C. L. Simpson and J. J. Fuquay, 1971. Final Report on a Meteorological Evaluation of the Proposed Cooling Towers at the Hanford Number Two "C" Site on Surrounding Areas. Contract BR-2808-7, Battelle, Pacific Northwest Laboratories, Richland, WA 99352. Report to Burns \& Roe, Inc., Hempstead, NY. 
SUSPENSION OF RADIOACTIVE MATERIAL FROM BURIED WASTE AND CONTAMINATED SOIL REMOVAL OPERATIONS ${ }^{(\mathrm{a})}$

Problem Statement

The potential exists for an increase in radiation dose from the Ben Franklin Dam project. This dose is related to the removal of a number of radioactively contaminated facilities. Disturbance of unsealed radioactive materials results in atmospheric suspension, producing the potential for a dose increase to the population in the Hanford region. This task considers the potential effect of the removal of buried waste and contaminated soil.

Assessment of potential impact requires definition of source terms, atmospheric transport, and uptake pathways. Source term definition depends on the form of the radioactive materials, removal and handling methods, and, for outdoor activities, ambient atmospheric conditions. In lieu of detailed removal plans, several assumptions on the removal activities are made to estimate source terms. The atmospheric model is a Gaussian model using onsite data. An uptake model is used to compute population dose.

The releases of radioactive materials to the atmosphere during the required removal operations are computed as routine release source terms over the term of anticipated effort. These routine releases increase the dose commitment in areas downwind. Releases during transport or disposal of radioactive materials are not included. The effect of the required removal activity is expressed in terms of increase in population dose.

Scope of Investigation

A potential effect of removing of buried waste and radioactively contaminated facilities is an increase in dose to local population.

A list of the radioactively contaminated Hanford facilities that may require removal to accommodate the Ben Franklin Dam project is given in Task 5 , Facility Decommissioning. The facilities include a variety of structures and installations, and the operations required to remove them are varied. Many involve removal of contaminated soil.

$\overline{\text { (a) J. G. Droppo }}$ 
Depending on the nature of the radioactive wastes, the removal may either be in an enclosed structure or open to the atmosphere (Figure 25). The assessment starts with the definition of a source term based on the se processes. Two options for facility removal involving buried radioactive wastes are described to illustrate their influence on source term definition.

Following definition of the source term, the atmospheric processes of dispersion, deposition on (wet and dry) surfaces, and resuspension are considered. The last column in Figure 25 lists the processes controlling dose rates. These include atmospheric submergence (direct irradiation), inhalation, ground irradiation, ingestion, and the radioactive half-lives of the materials.

\section{Source Terms}

The estimated source terms associated with the removal of each structure, burial ground, or other facility are based on a number of assumptions, including whether the operations take place in temporary enclosures from which airborne effluents pass through double high efficiency particulate air (HEPA) filters, or are open to the atmosphere. The radioactive releases are treated as a routine release occurring over a l-year period. The actual operations may extend over a longer or shorter time period. The source terms are estimated for each facility based on the data available on inventory of radioactive materials, form of the radioactive materials, and physical characteristics of the facility. In addition, assumptions are made on the types of activities involved in the removal processes and on the size distribution of the radioactive particles.

The estimation of suspension of radioactive materials during removal operations is in two parts. The first is the radioactive material suspended during the mechanical operations related to removing radioactively contaminated materials. The second is the radioactive material suspended over exposed radioactively contaminated surfaces.

The resuspension factor $\left(\mathrm{m}^{-1}\right)$ discussed below represents the ratio of the airborne activity $\left(\mu \mathrm{Ci} \cdot \mathrm{m}^{-3}\right)$ and the surface activity $\left(\mu \mathrm{Ci} \cdot \mathrm{m}^{-2}\right)$. This factor allows estimation of air concentrations over exposed radioactively contaminated surfaces. 


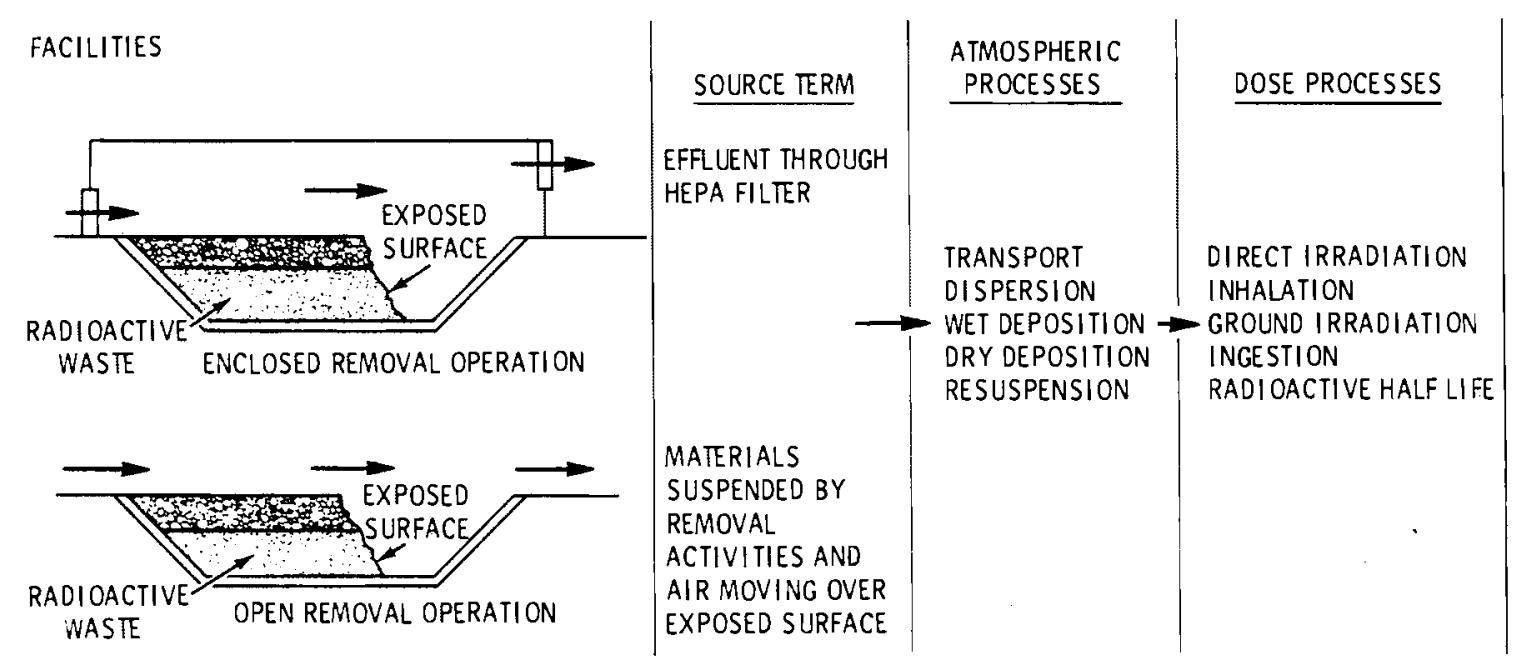

FIGURE 25. Schematic of Processes Involved in Population Dose from Two Removal Activity Options, Illustrated with an Exaggerated Vertical Scale

Data to estimate the surface suspension factors are based on studies of the resuspension rates of radioactive materials deposited on natural surfaces. Suspension and resuspension are different names for the same processes.

In studies of plutonium and uranium contamination, resuspension factors were in the range of $7 \times 10^{-7}$ to $7 \times 10^{-5} \mathrm{~m}^{-1}$ (Sandia 1961) compared to values of $10^{-13} \mathrm{~m}^{-1}$ for similar thoroughly weathered material (0lafson and Larson 1961). The resuspension factors also depend on the physical action on the surface. Sehmel (1972) determined resuspension of 0.001 to 1 percent of freshly deposited tracer particles on an asphalt road per pass using a car or 3/4-ton truck. Higher resuspension rates corresponded to higher vehicle speeds. A marked decrease of resuspension was observed with weathering.

The resuspension of plutonium particles was measured by Jones and Pond (1967). They studied suspension from paper-covered, plastic-covered and waxed linoleum surfaces with particles ranging from 0.4 to $60 \mu \mathrm{m}$. Higher suspension factors were obtained from surfaces contaminated by oxide than nitrate. When the plutonium was applied as a solution, absorbent paper surfaces gave lower suspension factors than sound impermeable surfaces. 
Higher suspension factors correlated with increased activity. Suspension factors on the order of $2 \times 10^{-8} \mathrm{~m}^{-1}$ were found with no movement and $10^{-6}$ to $10^{-5} \mathrm{~m}^{-1}$ with walking.

Glauberman, Boatman and Breslin (1967) measured suspension of aged material from concrete surfaces in an oid production facility. Factors for plutonium oxide ranged from $10^{-6}$ to $10^{-7} \mathrm{~m}^{-1}$ for no movement before the test, $10^{-3} \mathrm{~m}^{-1}$ for no movement after the test, $10^{-3} \mathrm{~m}^{-1}$ with air circulation over the surface, to $10^{-2} \mathrm{~m}^{-1}$ when a dolly was run over the surface with air circulation.

Thus, for suspension, the form of radioactive substance, the surface, the entraining force and mechanical operations all play a role. Particles entrain more readily than solutions. Direct transfer of momentum is a more effective mechanism for suspension than aerodynamic forces. Freshly disturbed or recently deposited materials are more readily entrained than weathered material. Hence, the removal operations provide a situation for maximum suspension of radioactive materials.

Definition of source terms of required removal activities has the largest uncertainty of processes involved in the computation of potential effects. Formulation of specific plans for the soil removal operations at each facility and detailed information on the exposed radioactive surfaces and removal methodology, now assumed on a generic basis, would improve the bases for estimating source terms.

Specific data on parameters relating to suspension rates such as the air flow rate, the size distribution of radioactive particles, size of exposed areas, time schedule, and types of removal activity would also improve the source term estimate. Values of the parameters were selected as representative of the situation anticipated for the removal activities.

A generic scenario for estimating the potential magnitude of suspension of radioactive materials requires definition of the release processes. The studies quoted above suggest that suspension values during mechanical disruption of surfaces have a range up to $10^{-2}$ to $10^{-3} \mathrm{~m}^{-1}$. The moving of materials within the structure will result in releases estimated to be $10^{-3}$ of the 
inventory moved. This latter fraction is based on the assumption that the mechanical operations are such that 1 percent of material moved is injected into the air; of that, 10 percent is assumed to remain airborne within the structure. The 10 percent fraction remaining airborne is conservative to allow for uncertainty in the size distribution definition. This makes allowance for the fact that some radioactive materials will be parts of large equipment or enclosed in containers. In addition, during quiet periods within an enclosed structure the suspension factor for releases from radioactively contaminated surfaces exposed during the removal operations is $10^{-5} \mathrm{~m}^{-1}$, This is typical of the larger values observed for relatively quiet conditions without mechanical action on the surface.

Removal operations are assumed to take between 30 and 90 days depending on the facility characteristics. The exposed area of radioactive material is based on the physical dimensions of the facilities assuming that a $1: 1$ sloped surface is exposed along the narrowest dimension of the facility and the surface activity is assumed to be the radioactivity contained in the first inch of the exposed surfaces.

A11 radioactive materials are assumed to become airborne within an enclosed structure at negative pressure with all effluents through two absolute filters. The efficiency of removal of each of these filters is on the order of $5 \times 10^{-4}$ of airborne concentrations. A factor of only $10^{-6}$ is used for the two filters. This allows for factors such as a possible reduction in efficiency related to the size distribution of the particles.

These operation assumptions are generated for the sole purpose of providing a basis to compute the possible order of magnitude of the impact of the removal activities. The estimates will not be valid for significant departures from these conditions stated above. The details of the removal assumptions are based on studies of generic removal problems and, as such, they cannot be used as a design basis for the removal activities.

The source terms from open removal operations illustrated in Figure 26 are potentially much greater than from enclosed structures. The enclosed structure will have consistently low suspension rates as a result of 
consistent low rates of airflow over the exposed surfaces. In addition, the concentration of any suspended materials will be reduced by fiitration before reaching the free atmosphere. On the other hand, the open removal operation has a potential for much higher suspension rates depending on surface conditions, ambient wind conditions, atmospheric turbulence, and atmospheric stability. With no filtration the suspended materials constitute the source term in the open removal operation.

Significant Findings

The removal of radioactively contaminated soil and wastes is estimated to result in a fractional release of materials, on the order of $10^{-9}$ of the radioactive inventories. The mechanical suspension process dominates the source term.

The use of open operations for all removal operations increases the estimate of potential impact by six orders of magnitude allowing only for the lack of filtration. In addition, the fractions related to releases during mechanical operations will increase at higher wind speeds. This increase in suspension rátes may result in source terms as high as 0.10 of inventories, although proper techniques should keep this as low as 0.01 of inventories for open removal operations. These approach the level where more detailed anaiys is is merited.

\section{Recommendations}

It is recommended that further analysis of potential radiological impacts be performed when engineering $p l a n s$ for removal of specific facilities are formulated. If enclosed removal with HEPA filters is used, the potential impact from routine operations appears to be quite small and this analysis may be sufficient for soil suspension impact.

If open removal operations are considered, it is recommended that a detailed reassessment of potential impact be performed for individual facilities. Field tests may be required to establish more accurately the factors that are used in the calculations. 
The release scenarios in either case will require better definition.

This includes the following:

- accidental release time periods

- representative meteorological data

- definition of downwind trajectories

- additional radionuclides

- definition of surface properties.

It is recommended that regardless of the removal options, an analysis be made to define the consequences of accidents or unexpected phenomena during the removal operations. This can be a generic analysis providing similar removal operations are used at each facility. Accidents include potential effects of tornadoes, dust devils, high wind speeds, combustion and explosions.

\section{REFERENCES}

Glauberman, H., W. R. Boatman and A. J. Breslin. 1967. "Studies of the Significance of Surface Contamination." In: B. R. Fish, ed., Surface Contamination. Pergamon Press, New York, NY.

Jones, I. S., and S. F. Pond. 1967. "Some Experiments to Determine the Resuspension Factor of Plutonium from Various Sources." In: B. R. Fish, ed., Surface Contamination. Pergamon Press, New York, NY.

01 afson, J. H., and K. H. Larson. 1961. Plutonium: Its Biology and Environmental Persistence. UCLA-501, University of California at Los Angeles, Los Angeles, CA.

Sandia Base, 1961. The Hazards and Characteristics of Plutonium and Uranium Contamination. NP-10053, Nuclear Branch, AWSG, Field Command, DASA. Sandia Base, Atbuquerque, NM.

Sehmel, G. A., 1972. Particle Resuspension from Asphalt Roads Caused by Car and Truck Traffic. BNWL-SA-4175. Pacific Northwest Laboratory, Richland, WA 99352. 


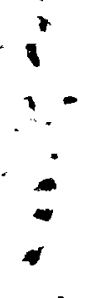

a 


\section{TERRESTRIAL ECOLOGY (a)}

Ecological systems develop over long periods of time, and can survive 1 arge variations in natural conditions. Persistent changes in natural conditions, such as occur now in the daily fluctuation of the Hanford Reach of the Columbia River, severely stress some species. The total effect of that change has yet to be assessed. Creation of a reservoir in the Hanford Reach would have even greater effects. Some of these effects are known from other studies, and to the extent that they are known, the results are extrapolated to the Ben Franklin Dam case.

To properly assess the net effect of inundating 15 existing.islands and creating about 40 new islands, and of inundating 11,500 acres of riparian 1 ands and creating 16,000 acres of new lands, requires significant study. A 3-5 year study estimated at $\$ 100,000$ per year would probably be required. However, we have attempted to highlight some of the more obvious ecological problems which would probably arise as a result of the Ben Franklin Dam.

UNUSUAL HABITAT

One of the few remaining undarmed reaches of the Columbia River flows through the Hanford Site and certain lands designated by DOE as the Hanford National Environmental Research Park (NERP). Swift flowing rivers such as the Columbia of ten have a border of clean cobblestone shorelines. These cobble shorelines provide harsh environments for most kinds of terrestrial plants: cobbles provide poor rooting substrates, and cobblestone shores have historically been flooded every year during the spring freshet. A few plant species are adapted to these spring-flooded cobblestone shores, but these plant species do not occur in the (noncobblestone) soils adjacent to the shoreline. Dams along the Columbia have already eliminated many cobblestone habitats by inundation, resulting in significantly decreased populations of plants that have the ability to grow on riverine cobbles.

Preliminary field investigations by PNL scientists indicate that Columbia River shoreline cobble habitats do indeed support plant species not found

(a) W. H. Rickard and W. T. Hinds 
elsewhere on the Hanford Site. However, these species are not listed in the U.S. Army Corps of Engineers 1976 report on riparian habitats and associated wildlife.

The 1976 report is not definitive enough to fully assess the impact of Ben Franklin Dam impoundment on those unusual plant communities inhabiting Columbia River shoreline cobblestone habitats along the Hanford segment of the Columbia River. It is recommended that an investigation be made to describe and document the species composition of Columbia River shoreline cobblestone habitàts.

\section{CANADA GOOSE}

A resident population of the Canada Goose has nested on islands in the Columbia River on the Hanford Site for 35 years (Hanson and Eberhardt 1971). The impoundment created by Ben Franklin Dam will inundate some of the nesting islands resulting in substantial population losses.

Studies of the nesting success of the island nesting geese on the Hanford Site have been conducted since 1953 by DOE. A few pairs of geese have nested in trees and in the cliffs at White Bluffs. Special nest platforms elevated above ground beyond the reach of ground-dwelling predators (coyote) were seldom used by nesting geese.

It is recommended that a plan be formulated in cooperation with the various waterfowl management agencies to mitigate Canada Goose population losses resulting from Ben Franklin Dam impoundment. One aspect of the plan shouid relate to avoiding filling the reservoir during the spring period of goose nesting.

HERONS

The great blue heron is a colonial, tree nesting bird that feeds its young primarily on fish gathered from nearby lakes and streams. A heron colony nests in a grove of tall poplar trees along the banks of the Columbia River on the Hanford Site near the ferry landing at White Bluffs. It is the only known colony between McNary Dam and Priest Rapids Dam. The colony is 
useful as an indicator of food chain contamination by a high trophic level animal and has been studied for several years by collecting debris cast from the nests and analyzing the collected material for chemical contaminants (Rickard, Hedlund and Schreckhise 1978).

Construction of Ben Franklin Dam and its impoundment could flood out or at least accelerate the die-off of the nest trees and cause the heron colony to seek nest sites elsewhere.

It is recommended that a population tagging study of the great blue heron colony at $\mathrm{Hanford}$ be initiated so that the fate of the colony can be predicted should construction of Ben Franklin Dam proceed.

\section{BALD EAGLE}

The American bald eagle is a winter resident along the Hanford segment of the Columbia River, where it feeds principally on the carcasses of spawned out salmon and/or hunter-wounded waterfowl (Fitzner and Hanson 1978).

In recent years wintering populations of bald eagles at Hanford have increased substantially, probably affected by available food. Although the bald eagle is regarded as "endangered" in most states, it is termed "threatened" in the state of Washington. Nesting populations of bald eagles are mostly located in western Washington. It is expected the Ben Franklin Dam impoundment will decrease the eagles' traditional food supply (dead salmon) and cause them to abandon their current wintering behavior along this reach of the river.

It is recommended that pre- and post-dam eagle censuses be made to determine if impoundments are as attractive to wintering eagles as freeflowing water. Also, the relative importance of salmon in the diets of eagles wintering along the $H$ anford segment of the Columbia River should be examined to predict effects of the dam, if constructed.

\section{CLIFF SWALLOWS}

Large numbers of cliff swallows have historically nested on the steep cliffs known as White Bluffs. Filling of the Ben Franklin Dam impoundment can be expected to accelerate cliff erosion. If the impoundment is filled coincident with the swallow nesting season, large numbers of young swallows would be killed. 
It is recommended that filling of the Ben Franklin Dam impoundment be scheduled to avoid the swa?? ow nesting season.

CALIFORNIA QUAIL AND RING-NECKED PHEASANT

Riparian tree-shrub communities provide shelter from adverse weather conditions and predators. Because of the extreme aridity of most of the Hanford Site lands, deciduous trees and shrubs are confined to lands near the Columbia River. These trees and shrubs provide cover needed for maintenance of quail and pheasant populations. Inundation by the Ben Franklin Dam impoundment will eliminate suitable nesting habitats and expose California quail and Chinese ring-necked pheasant to weather and predation.

It is recommended that $p l$ ans be made in cooperation with agencies responsible for upland game bird management for mitigating habitat losses for California quail and Chinese ring-necked pheasant.

\section{MULE DEER}

The mule deer is the most abundant big game animal on the Hanford Site, (Steigers 1976). The riparian tree-shrub communities along the Columbia River and associated is lands provide important fawning areas for mule deer. The islands are especially important to deer in the fawning season because of the protection they provide against predators, especially the coyote.

The construction of Ben Franklin Dam and its impoundment will elimirate some islands as fawning places for deer, inundate tree-shrub communities and probably expose newborn fawns to increased predation by coyotes unless newly formed islands in the reservoir can be used.

It is recommended that a pre- and post-dam construction census of the Hanford mule deer be conducted. Island utilization by mule deer in existing impoundments should be examined to aliow prediction of the effects of the dam.

ENDANGERED PLANT SPECIES

The Endangered Species Act of 1973 aims to protect those species regarded as being close to extinction. Federal construction projects may not be undertaken unless adequate measures are taken to insure that endangered species will 
not be deleteriously impacted by construction or operation of a particular facility.

Astragalus columbianus, a plant species indigenous to the Columbia Basin and officially listed as endangered and thought to be "extinct" was "rediscovered" near Priest Rapids Dam in the spring of 1978 (Sauer, Mastroguiseppe and Smookler 1979). Preliminary investigations indicate that $A$. columbianus occurs as small isolated populations.

Definitive information on the abundance and geographic distribution of A. columbianus is lacking. Such information is needed to fully assess the impact of the Ben Franklin Dam and impoundment on the population of this species.

It is recommended that an investigation be undertaken to definitively describe the existing population of $A$. columbianus and then relate the findings to those land areas expected to be inundated by Ben Franklin Dam impoundments. Other species are thought to have similar potentials, such as Allium robinsoni $i$ and may warrant fuller investigations.

\section{REFERENCES}

Fitzner, R. E., and W. C. Hanson. 1978. Wintering Eagles Along the Columbia River. BNW SA 6462, Battelle, Pacific Northwest Laboratories, Richland, WA $\overline{99352}$.

Hanson, W. C., and L. L. Eberhardt. 1971. "A Columbia River Canada Goose Population." Wildl. Monogr. No. $28 ., 61$ pp.

Rickard, W. H., J. D. Hedlund and R. G. Schreckhise. 1978. Rejecta Cast From Heron Nests as an Indicator of Food Chain Contamination. AUK. 95:425-427.

Sauer, R. H., J. Mastroguiseppe and R. Smookler. 1979. Astragalus columbianus: Rediscovery of an extinct species. Brittonia (in press).

Steigers, W. D. 1976. Mortality of Radio-Collared Mule Deer Fawns on the Hanford Reservation. MS Thesis, Brigham Young Univ., p. 35.

U.S. Corps of Army Engineers, North Pacific Division. 1976. Inventory of Riparian Habitats and Associated Wildlife Along Columbia and Snake Rivers, Vol. 4. 
1

$a$ 


\section{AQUATIC ECOLOGY (a)}

This section identifies potential effects of the proposed Ben Franklin Dam on aquatic organisms and aquatic ecosystem production in the Hanford Reach of the Columbia River. This initial evaluation does not permit detailed consideration of 211 potential impacts, but it does represent the knowledgeable opinion of PNL scientists with expertise in aquatic ecology and familiar with the ecosystem potentially affected by the proposed facility. Detailed evaluation is recommended to further define the severity of impacts on vuinerable aquatic ecosystems prior to irreversibly committing resources to the construction of Ben Franklin Dam.

The proposed Ben Franklin Dam would inundate a unique and productive area of the Columbia River. This last remaining free-flowing (unimpounded) stretch of river in the United States (above Bonneville Dam) provides critical habitat for a number of important aquatic species (Gray and Dauble 1977) and is a valued resource. Continued production of several species of valued fishes would be endangered if the free-flowing section is inundated by the Ben Franklin Dam impoundment. Adult Chinook salmon and steelhead trout spawn in the area that would be flooded. The vulnerable white sturgeon is present and is believed to require a pristine, flowing river for successful reproduction. Smallmouth bass spawn in backwater areas and sloughs which also provide nursery areas for fry of many species. Mountain whitefish spawn in and migrate through the area. Coho and sockeye salmon also migrate past the proposed dam site to spawn above it. The Sand Roller, an unusual species of limited abundance, also exists in the Hanford Reach. This species is endemic to the Columbia River system and is found mainly in the lower Columbia River (Gray and Dauble 1976).

The Hanford Reach of the Columbia River contributes a significant portion of the Columbia River salmon fishery. This population is the "fall upriver bright" race which is especially prized. About one-third of the Hanford production results from spawning near Vernita $B$ ar where an estimated 1000 redds

(a) D. H. Fickeisen 
are observed annually. The remaining two-thirds of the fianford spawning (about 2000 redds annualiy) are found downstream of Vernita Bar (watson 1970, 1976).

The proposed dam would inundate important Chinook salmon spawning areas and eliminate production of Chinook fry below Vernita Bar. Spawning areas near Vernita Bar would be affected in the upper end of the pool, and these areas would be subjected to reduced water current and siltation. Loss of salmonid production at Hanford would have a significant impact on sport and commercial fisheries and would severely limit natural production of salmon in the Columbia River. Additionally, the dam would impede adult salmon migrating from the sea to their spawning grounds above the proposed site. While fish ladders could be provided, they are not entirely effective and serve as sites of concentration of disease organisms (Becker and Fujihara 1978).

Salmonid fry migrating downstream from areas above the dam would be subject to additional mortalities due to increased residence time in the river, mechanical damage in passing the dam, and potential gas bubble disease resulting from dissolved gas supersaturation of river water passing the dam (Ebel et ai. 1975).

According to Watson (1973), an estimated 10,000 stee lhead trout spawn in the Hanford Reach annually. Several thousand more migrate through the area and are counted at Priest Rapids Dam (Allen 1977). They would be subject to the same impacts as Chinook salmon. Plans to mitigate for these extensive losses of anadromous salmonids (Chinook salmon and steelhead) by increasing hatchery or spawning channel production fail to acknowledge that such schemes have not been very successful or cost-effective and fail to account for differences in ecological and aesthetic value between hatchery-reared and wild fish.

Smallmouth bass utilize slough areas in the Hanford Reach as spawning sites, but they favor the free-flowing section most of the year. Recently the public has been granted access to these areas and the Washington State Department of Game is concerned with the impact of excessive fisting pressure on spawning bass. Adult smallmouth bass migrate from sloughs to areas below the proposed dam site after spawning (Montgomery and Fickheisen 1979). Dart tag returns from sport fishermen also show! a movement of bass from slough 
areas into the McNary pool. Smallmouth have also been shown to move from the Yakima River into sloughs in the Hanford Reach (Henderson and Foster 1957). Ben Franklin Dam would block these migrations. Since smallmouth bass are becoming increasingly popular sportfish, the importance of the Hanford area as it now exists to sustaining their regional populations should be fully investigated prior to developing an environmental report for Ben Franklin Dam.

Mountain whitefish larvae occur seasonally in large numbers in the Columbia River at Hanford and adults are thought to migrate upstream to spawn in areas where sufficient currents exist. Movements of whitefish from the Columbia River into the Yakima River and as $f a r$ as $42 \mathrm{~km}$ upstream from the Hanford Reach have been reported (Cushing and Watson 1966). Ben Franklin Dam would inhibit their movement and inundate the apparent spawning sites. Additional research should be conducted to examine the life history of whitefish, particularly with regard to movements and location on spawning sites.

White sturgeon are present in this stretch of the river in significant numbers. These very large and long-lived fish normally migrates to and from ocean waters, but present dams restrict their movements al though they have been observed in fish ladders apparently moving upstream. Due to loss of habitat resulting from impoundments, this species is considered highly vulnerable to further manipulation of available habitat. While little is known of sturgeon life history, they appear to require free-flowing waters in which to spawn. (Scott and Crossman 1973). Movements of sturgeon from the . Hanford Reach into the McNary pool have been recently noted (Haynes 1978). Ben Franklin Dam would restrict sturgeon movement and would eliminate the last free-flowing portion of the Columbia River, which may be critical to continued sturgeon reproduction in the area.

Creation of an impoundment would favor production of spiny-rayed and rough fish, further altering the composition of fish fauna. The species composition and productivity of organisms at lower trophic levels would also be altered, resulting in an impact on the food base for production of desired species. Slower currents and siltation of the existing well-scoured riverbed will represent a significant habitat modification. As a result the present riverine aquatic community will be replaced by a more lacustrine one. The 
diverse crayfish and aquatic insect populations, which characterize the existing bentinic community and support a variety of game fish stocks, will be altered in favor of forage species less desirable for game fish production.

The proposed dam represents a potential for generation of dissolved gas supersaturation, increasing the incidence of gas bubble disease among organisms below the dam. A very slight modification of river water temperatures may also occur, although effects on ecosystem components would likely be negligible.

Water level fluctuations below the proposed Ben Franklin Dam that are caused by changes in release from the dam may be severe, particularly if the dam is operated in a load-following, peaking mode of generation. These may be expected to result in stranding and entrapment of organisms on the river shore as beach exposure changes and will inhibit establishment of riparian vegetation. Water level fluctuations in the pool may be damped from their present range slightly; however, their impact may be severe if the new shoreline is rough and contains potential intermittent ponds rather than a smooth, un iformly gentle slope. With the expected beach slope very slight along the right bank of the reservoir, entrapment of organisms will continue and mortalities will likely exceed those of the present system.

In summary, construction and operation of Ben Franklin Dam would result in substantial impacts to the Columbia River ecosystem with long-term effects on aquatic communities and production of valued species. These populations are already severely impacted by the effects of hydroelectric generation and other water uses. In many cases we have only limited knowledge of the habits and life histories of the organisms involved.

\section{REFERENCES}

Allen, R. L., 1977. Status of the Upper Columbia River Salmon and Steelhead Runs, pp. 23-30, Columbia River Salmon and Steelhead, E. Schwiebert, ed.,

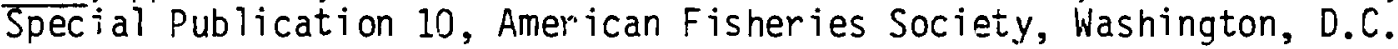

Becker, C. D., and M. P. Fujihara. 1978. The Bacterial Pathogen Flexibacter Columnaris and Its Epizootiology Among Columbia River Fish, Monograph No. 2, American Fisheries Society, Washington, D.C. 
Cushing, C. E., and D. G. Watson. 1966. "Accumulation and Transport of Radionuclides by Columbia River Biota, Disposal of Radioactive Wastes into Seas, Oceans, and Surface Waters, pp. 551-570, International Atomic Energy Agency, Vienna.

Ebel, W. J., H. L. Raymond, G. E. Monan, W. E. Farr and G. K. Tanonaka. 1975. Effect of Atmospheric Gas Supersaturation Caused by Dams on Salmon and Steelhead Trout of the Snake and Columbia Rivers. "Northwest Fisheries Center, Processed Report," National Marine Fisheries Service, Seattle, WA, pp. 111 .

Gray, R. H., and D. D. Dauble. 1977. "Checklist and Relative Abundance of Fish Species from the Hanford Reach of the Columbia River." Northwest Science. 51(3): 208-215.

Haynes, J. M. 1978. Movement and Habitat Studies of Chinook Salmon and White Sturgeon. PNL-2471, Pacific Northwest Laboratory, Richland, WA 99352.

Henderson, C., and R. F. Foster. 1957. "Studies of Smallmouth Black Bass (Micropterus dolomieui) in the Columbia River near Richland WA." Trans. Am. Fish Soc. 86: $112-127$.

Montgomery, J. C., and D. H. Fickeisen. 1979. Spawning and Movements of Smalimouth Bass (Micropterus dolomieui) in the Mid-Columbia River, PNL-2785 - Pacific Northwest Laboratory, Richland, WA 99352.

Scott, W. B., and E. J. Crossman. 1973. Freshwater Fishes of Canada. Bulletin 184, Fisheries Research Board of Canada.

Watson, D. G. 1970. Fall Chinook Salmon Spawning in the Columbia River Near Hanford 1947-1969. BNWL-1515, Battelle, Pacific Northwest Laboratories, Richland, WA 99352.

Watson, D. G., 1976. Temporal and Spatial Fall Chinook Salmon Redd Distribution Near Hanford, 1967-1976. BNWL-2163, Battelle, Pacific Northwest Laboratories, Richland, WA 99352.

Watson, D. G., 1973. Estimate of Steelhead Trout Spawning in the Hanford Reach of the Columbia River, Report to U.S. Army Corps of Engineers, Contract DACW67-72-C-0100, BatteTTe, Pacif ic Northwest Laboratories, Richland, WA. 
1
4
4

? 


\section{SOCIOECONOMIC EFFECTS}

Potential socioeconomic impacts from a Ben Franklin Dam are dependent on other construction-type activities and the general pattern of growth that might be occurring in the area. As currently envisioned, dam construction might commence in about 1987 and continue for about 7 years. A precise work force schedule could not be obtained, but it is estimated to be in the range of 1500 to 2000 workers based on similar construction projects.

A11 reactor construction work currently scheduled on the Hanford Site will have been completed. Further, all Pacific Northwest thermal power plant additions through 1989 have been committed to specific sites, none of which is at Hanford. Assuming the next thermal (nuclear) plant is scheduled for completion in 1990 and is sited at Hanford, then the following construction work forces might build up at Hanford:

\begin{tabular}{|c|c|c|c|}
\hline Year & Ben Franklin Dam $(a)$ & Reactor $(b)$ & Total \\
\hline 1985 & & 400 & 400 \\
\hline 1986 & & 1000 & 1000 \\
\hline 1987 & 400 & 1600 & 2000 \\
\hline 1988 & 1000 & 2000 & 3000 \\
\hline 1989 & 1600 & 1100 & 2700 \\
\hline 1990 & 2000 & 100 & 2100 \\
\hline 1991 & 2000 & & 2000 \\
\hline 1992 & 2000 & & 2000 \\
\hline 1993 & 1100 & & 1100 \\
\hline 1994 & 100 & & 100 \\
\hline
\end{tabular}

The combined peak work force of 3000 compares with over 5000 now employed in construction at WNP 2, 1 , and 4 .

(a) Assumed to have a manpower buildup not unlike a nuclear plant but with a longer peak construction force.

(b) Based on WPPSS manpower estimates for WNP 3. 
A second nuclear plant coming on line in 1992 would result in total work forces not unlike those presentiy being experienced at Hanford.

To these work forces might be added those which could be involved in 100 Area decommissioning activities and the Basalt waste Isolation Project, should they materialize in the same time frame. 


\section{PUBLIC INTERACTION WITH HANFORD}

The plan for the Ben Frank lin Dam project includes three recreation areas: Ben Franklin Recreation Area (800 acres), Ringold Recreation Area (115 acres), and Vernita Recreation Area (400 acres), as shown in Figure 1. Each would provide camping, picnicking, boat-launching, swimming, and parking facilities. Access roads would be provided to the recreation areas. Thus, there would be the potential for a much greater public access to the Hanford Site than has existed in the past.

Exhibits 7 and 8 in Volume 1 of the Ben Franklin Lock, Dam, and Reservoir Survey Report (July 1969) speak to these concerns, and suggest that, in part, a final decision depends upon activities at Hanford contemporary with dam construction and operation.

As stated in Task 5, some of the deactivated Hanford facilities could be considered to be attractive nuisances. Adequate barriers would need to be erected if these facilities are not dismantled prior to completion of the dam. Beyond that, plant security and public safety factors would need to be considered.

A detailed study of the public's interaction with Hanford Site upon construction of the Ben Franklin Dam and associated facilities should be made. The cost of such a study has not been estimated. 


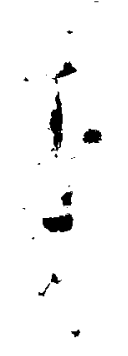




\section{OFFSITE}

DOE-RL

L. F. Perkins (50)

\section{ONSITE}

PNL

F. W. Albaugh

T. W. Ambrose

R. E. Brown

S. M. Brown

M. D. Campbe 11

D. B. Cear lock

J. P. Corley

D. W. Dragnich

J. G. Droppo

E. A. Eschbach

S. J. Farmer

D. H. Ficke isen

J. J. Fuquay

H. Harty (10)

C. H. Henager

W. T. Hinds/W. H. Rickard

L. D. Kannberg

J. C. King

J. W. Litchfield

D. E. Olesen

L. Rader

J. V. Rams de 11

J. R. Raymond

A. E. Reisenauer

B. E. Vaughan/R. F. Foster

W. H. Walters

Yo 
3

4 